JULIANA CRISTINA LUVIZOTTO

\title{
RESPONSABILIDADE CIVIL DO ESTADO \\ LEGISLADOR: ATOS LEGISLATIVOS \\ INCONSTITUCIONAIS E CONSTITUCIONAIS
}

\author{
Dissertação de Mestrado \\ Orientador: Prof. Dr. Edmir Netto de Araújo
}

FACULDADE DE DIREITO DA USP

SÃO PAULO

2010 
JULIANA CRISTINA LUVIZOTTO

\section{RESPONSABILIDADE CIVIL DO ESTADO \\ LEGISLADOR: ATOS LEGISLATIVOS \\ INCONSTITUCIONAIS E CONSTITUCIONAIS}

Dissertação de Mestrado apresentada à Banca Examinadora da Faculdade de Direito da Universidade de São Paulo, como exigência parcial para a obtenção do título de Mestre em Direito, sob orientação do Prof. Associado Dr. Edmir Netto de Araújo

FACULDADE DE DIREITO DA USP

SÃO PAULO 
Banca Examinadora 


\section{AGRADECIMENTOS}

Agradeço ao estimado Professor Doutor Edmir Netto de Araújo, pela sempre pronta disposição em orientar-me e pelos seus prestimosos aconselhamentos e sugestões. Mais que um orientador, foi sempre amigo dos seus orientandos, ensinando-lhes mais do que Direito.

Aos Professores Fernando Dias Menezes de Almeida e Fernanda Dias Menezes de Almeida, pelas valorosas observações feitas quando do exame de qualificação, as quais contribuíram de forma muito significativa para o aperfeiçoamento do presente trabalho.

À Professora Dinorá Adelaide Musetti Grotti, que desde os tempos da graduação foi mais do que professora. Minha enorme e sincera gratidão por todo o incentivo, colaboração e amizade recebida nesses anos de convivência.

A todos os meus colegas de pós-graduação e também às amigas Marina Feferbaum e Juliana Palma, fontes de apoio e encorajamento. Aos meus amigos da graduação, especialmente Leonardo e Marina, por terem compartilhado do assunto desta dissertação com tanto entusiasmo.

Aos meus pais João e Sueli, que ao longo da vida não mediram esforços para proporcionar-me uma boa instrução. Aos meus avós João e Maria Luiza que, junto aos meus pais, desdobraram-se na minha criação.

Ao meu marido Ricardo pelo carinho e apoio fundamental à realização deste trabalho. 


\section{LISTA DE ABREVIATURAS}

\section{Sigla $\quad$ Significado}

ADIN Ação Direta de Inconstitucionalidade

AgR Agravo Regimental

AI Agravo de Instrumento

CE Comunidade Europeia

CF Constituição Federal

DJ Diário de Justiça

DJe Diário de Justiça Eletrônico

MS Mandado de Segurança

RE Recurso Extraordinário

RMS Recurso em Mandado de Segurança

RT Revista dos Tribunais

STF Supremo Tribunal Federal 


\section{RESUMO}

O escopo da presente dissertação é o estudo da responsabilidade civil do Estado Legislador, especificamente nas hipóteses em que o Estado emana atos legislativos inconstitucionais e constitucionais. Busca-se para tanto a análise do instituto da responsabilidade civil do Estado, sua natureza jurídica e evolução, bem como a compreensão do delineamento constitucional dispensado pelo ordenamento jurídico pátrio à matéria, tanto no que tange aos princípios justificadores quanto aos seus pressupostos de atuação e causas excludentes.

Perfaz-se, ainda, um estudo teórico da responsabilidade civil objetiva do Estado, diferenciando-a das situações em que se confere ao Estado a prerrogativa de realizar um sacrifício de direito, ao qual corresponde o dever de prévia indenização.

Adentrando no exame específico da função legislativa, serão decompostas as teorias que tentam explicar o conceito de lei ao longo da História, permitindo, ao final, compreender como ocorre o equacionamento desta função na ordem jurídica brasileira.

Um estudo crítico dos argumentos que negam a responsabilidade civil do Estado Legislador é realizado em seguida para que, então, firmada a possibilidade de responsabilização, seja possível expandir a análise para as hipóteses de atos legislativos inconstitucionais e constitucionais danosos, ocasião em que será demonstrado o entendimento posto sobre a matéria tanto no direito pátrio quanto estrangeiro.

Ao final, será elaborada a síntese conclusiva em relação à responsabilidade civil do Estado Legislador nas hipóteses acima referenciadas, de acordo com os estudos desenvolvidos ao longo do presente trabalho.

Palavras-chave: Estado - responsabilidade civil - função legislativa - direito administrativo. 


\begin{abstract}
The scope of this dissertation is to study the civil liability of the Legislating State, considering constitutional and unconstitutional legislative acts. In order to do this, it's necessary to analyze the State's liability, its legal nature and evolution, as well as the constitutional outline of the native legal system, regarding principles and its assumptions and exclusions.

A theoretic study of the objective State liability is also carried out, by putting it against situations in which the State has the right to taking, thus corresponding to the right of prior indemnification.

Specifically regarding the legislative function, the theories concerning the concept of law throughout History will be examined, to understand how the legislative function is defined by Brazilian legal system.

A critical study of the arguments that deny civil liability of the Legislating State is then carried out so that once the possibility of responsibility has been confirmed it's possible to expand the analysis to the hypothesis of damaging legislative acts, both constitutional and unconstitutional, when the understanding of the subject, both in national as well as foreign law, would be demonstrated.

By the end, a conclusive synthesis about the civil liability of the Legislating State will be presented.
\end{abstract}

Keywords: State - civil liability - legislative function - administrative law. 


\section{SUMÁRIO}

INTRODUÇÃO................................................................................................................10

PRIMEIRA PARTE: A RESPONSABILIDADE CIVIL DO ESTADO ...................... 15

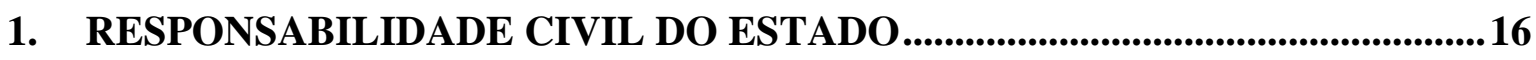

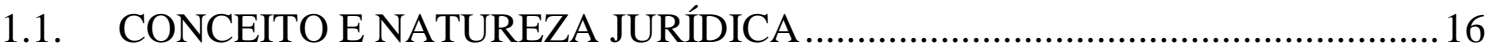

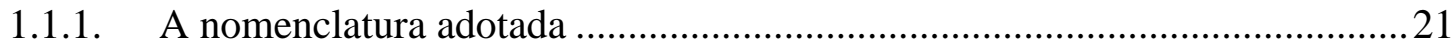

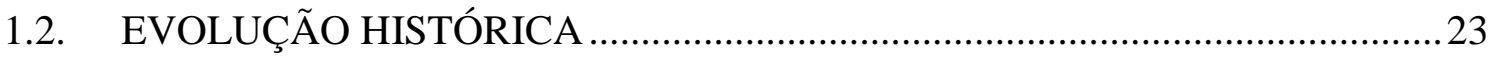

1.2.1. Fase da irresponsabilidade estatal ou teoria regalista .................................24

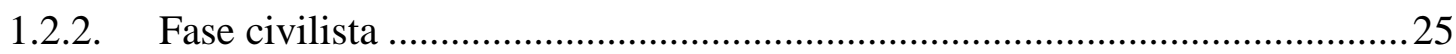

1.2.2.1. Teoria dos atos de império e dos atos de gestão...................................26

1.2.2.2. Teoria da culpa ou da responsabilidade subjetiva ................................2 27

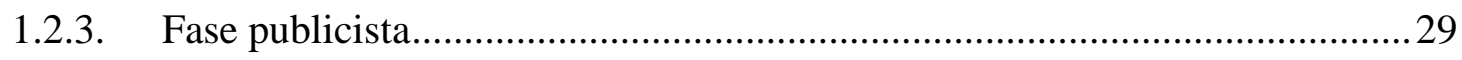

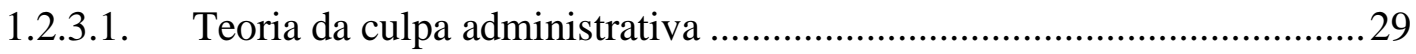

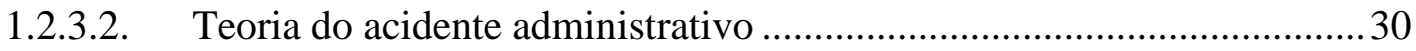

1.2.3.3. Teoria do risco ou responsabilidade objetiva ...................................... 32

1.3. EXCLUDENTES E ATENUANTES DA RESPONSABILIDADE OBJETIVA 37

\section{ASPECTOS TEÓRICOS DA RESPONSABILIDADE CIVIL OBJETIVA DO}

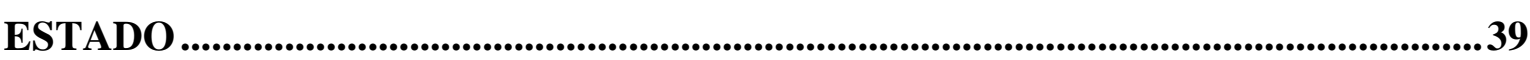

2.1. A ABRANGÊNCIA DE ATOS LÍCITOS E ILÍCITOS ........................................ 39

2.1.1. A ilicitude do resultado: o dano antijurídico ...............................................4

2.2. RESPONSABILIDADE CIVIL DO ESTADO POR ATO LÍCITO E O DEVER

DE INDENIZAR DECORRENTE DO SACRIFÍCIO DE DIREITO ............................50

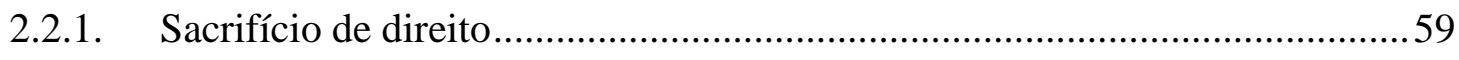

\section{O REGIME JURÍDICO DA RESPONSABILIDADE CIVIL DO ESTADO NO} ORDENAMENTO JURÍDICO BRASILEIRO .....................................................71

3.1. SÍNTESE DA EVOLUÇÃO NORMATIVA DA RESPONSABILIDADE CIVIL

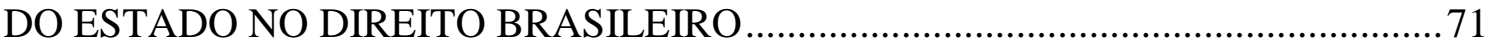

3.2. O CONTEÚDO DO ARTIGO 37, §6 $6^{\circ}$, DA CONSTITUIÇÃO .......................... 72

3.2.1. Atos comissivos ou omissivos, materiais ou jurídicos, lícitos ou ilícitos.......75

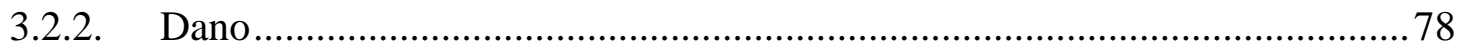

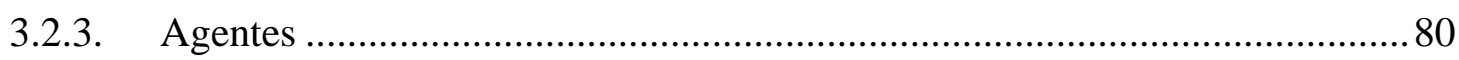

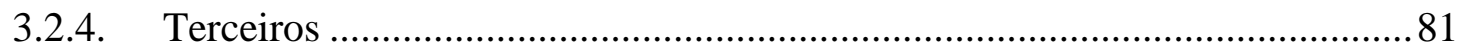


3.2.5. Nexo causal 82

SEGUNDA PARTE: A RESPONSABILIDADE CIVIL DO ESTADO LEGISLADOR 85

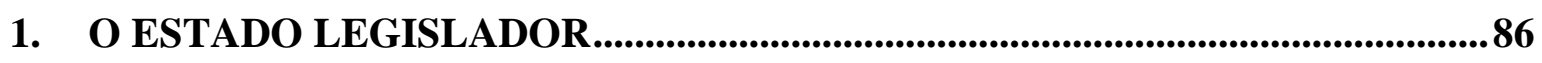

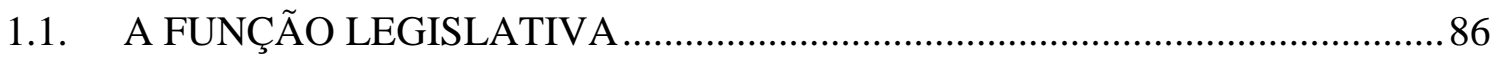

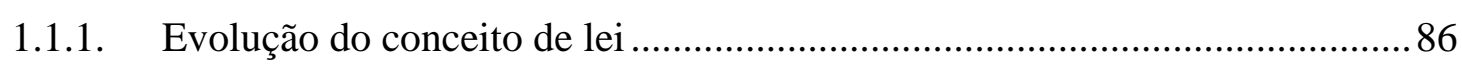

1.1.2. O Estado Legislador no Brasil ..................................................................... 93

2. A RESPONSABILIDADE CIVIL DO ESTADO LEGISLADOR .....................100

\subsection{ARGUMENTOS CONTRA A RESPONSABILIDADE CIVIL DO ESTADO}

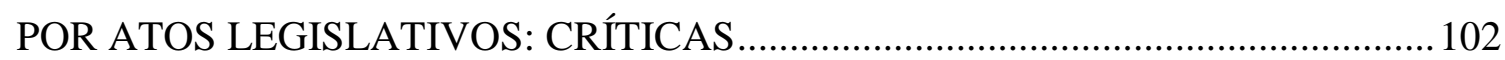

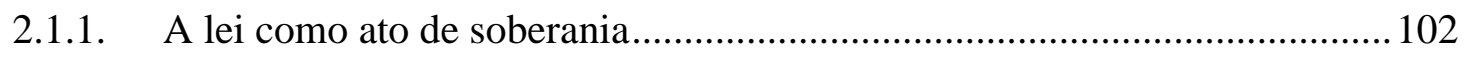

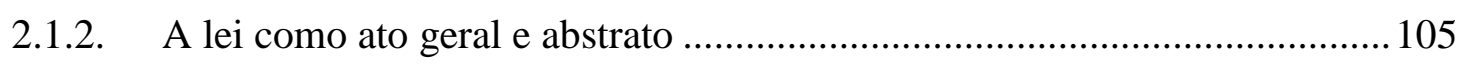

2.1.3. A lei como ato de criação dos direitos ......................................................... 106

2.1.4. A representatividade do órgão legislativo e a imunidade parlamentar ......... 108

2.2. HIPÓTESES DE RESPONSABILIDADE CIVIL DO ESTADO LEGISLADOR: ATOS LEGISLATIVOS INCONSTITUCIONAIS E CONSTITUCIONAIS ...............109

2.2.1. A responsabilidade civil do Estado por lei inconstitucional .........................110

2.2.1.1. Considerações sobre o controle de constitucionalidade no Brasil........ 111

2.2.1.2. A inconstitucionalidade da lei e a responsabilidade civil do Estado

Legislador

2.2.1.2.1. Argumentos para a admissão da responsabilidade civil do Estado pelo desempenho inconstitucional da função legislativa.

2.2.1.2.2. A necessidade de prévia declaração de inconstitucionalidade para fins de responsabilização do Estado pela edição de ato legislativo

2.2.1.3. A limitação da responsabilidade civil estatal em razão da modulação dos efeitos da inconstitucionalidade

2.2.1.3.1. A posição de Rui Medeiros em face do ordenamento jurídico português

2.2.1.3.2. A posição de Eduardo García de Enterría em face do ordenamento jurídico espanhol. 143

2.2.2. Responsabilidade civil do Estado por lei constitucional 151

2.2.2.1. Colocação do problema 152 
2.2.2.2. A necessidade de liberdade para o legislador acomodar o Direito às circunstâncias cambiantes

2.2.2.3. A segurança jurídica 161

2.2.2.3.1. Aspecto objetivo da segurança jurídica: o direito adquirido e seus correlatos (ato jurídico perfeito e coisa julgada) 162

2.2.2.3.2. Aspecto subjetivo da segurança jurídica: a proteção da confiança e da boa-fé 164

2.2.2.4. Dos limites ao processo legislativo 168

2.2.2.4.1. O direito adquirido como limite ao processo legislativo 169

2.2.2.4.2. A proteção à confiança como limite ao legislador 174

2.2.2.5. A legitimidade de afastamento da proteção ao direito adquirido e as expectativas legitimamente criadas por parte do legislador 185

2.2.2.5.1. O interesse público legitimador desse afastamento 186

2.2.2.6. O dever de previsão de indenização e a responsabilidade 191

2.2.2.6.1. A prática legislativa e a ausência de previsão indenizatória .......201

3. A RESPONSABILIDADE PESSOAL DO LEGISLADOR ..............................206

3.1. O DIREITO DE REGRESSO EM FACE DO LEGISLADOR ..........................206

SÍNTESE CONCLUSIVA........................................................................................209

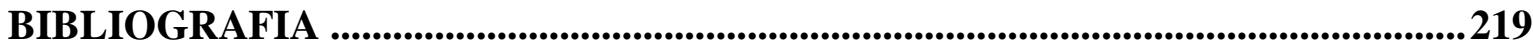

ANEXO - JURISPRUDÊNCIA .....................................................................................2227 


\section{INTRODUÇÃO}

A proposta deste estudo é analisar as possibilidades de responsabilização do Estado em virtude de sua atuação legislativa inconstitucional e constitucional, de acordo com o regime de responsabilidade albergado pelo ordenamento jurídico brasileiro. Vale dizer, pretende esta dissertação investigar os fundamentos, os pressupostos, as situações e as circunstâncias, inclusive excludentes, da responsabilidade civil do Estado Legislador pela sua atuação comissiva lícita ou ilícita.

Justifica-se a investigação sobre este tema na medida em que se observa pregar-se, ainda, em relação a essa esfera da atividade do Estado - a função legislativa - a subtração da possibilidade de ressarcimento. A despeito da grande evolução do instituto da responsabilidade civil aplicada ao Poder Público ao longo da História, a qual ganhou foros de independência do direito comum, consagrando também um regime objetivo, mais propício a permitir a sua atuação, subsistem argumentos acerca da impossibilidade de responsabilização quando o ato causador do dano é um ato legislativo, por se compreender que este não poderia causar qualquer prejuízo reparável, em função de ser o próprio ato criador dos direitos.

No entanto, observa-se que as justificativas apontadas, além de basearem-se em concepções de lei, de soberania, de representação, entre outras, construídas em outras épocas do constitucionalismo, encontram-se na contramão da tendência presente nos ordenamentos jurídicos contemporâneos, os quais visam cada vez mais alargar as possibilidades de reparação, posto que um dano não reparado é um fator de inquietação social. Essas justificativas também se encontram em contradição com os próprios direitos e garantias consagrados no ordenamento jurídico, em virtude da real e concreta possibilidade de existirem leis danosas.

Observa-se assim que o desenvolvimento de um estudo sobre a responsabilidade civil estatal, no sentido de compreendê-la como aplicável a qualquer ato estatal, mais do que corresponder ao reconhecimento de uma necessidade cotidiana, encontra-se de acordo com a busca da estabilidade por meio da consagração dos direitos fundamentais.

No tocante, especificamente, ao exame da responsabilidade civil aplicada ao Estado Legislador, a necessidade do desenvolvimento de uma sistematização teórica, capaz de 
construir os contornos que possibilitem a sua aplicação despida de controvérsias torna-se ainda maior diante do modelo de Estado atual e da existência de uma sociedade cada vez mais complexa, tecnológica e em constante mutação. É certo que o impulso dado à atividade legiferante após a eclosão do Estado Social, ao qual se demandava uma atuação mais incisiva e segmentada na vida dos particulares para permitir a concretização da igualdade, contribuiu tanto para a modificação das características da lei quanto para sua proliferação. Hodiernamente estes traços se conservam, de modo que existem leis sobre assuntos diversos, com as mais variadas características.

A multiplicação dos atos legislativos espelhou, contudo, a ausência de maturação sobre determinado assunto, o descuido com relação à repercussão do ato, razão pela qual somente após a sua aplicação é que se extraem, hoje, os seus inconvenientes e que se vislumbram os danos que provoca.

Em face desse quadro é que se avulta a importância do estudo do instituto da responsabilidade civil aplicada ao Estado Legislador, para que, através da compreensão hodierna do conceito de lei e do modo como se estrutura e se organiza tanto o Estado Legislador quanto a responsabilidade pública, levando em conta o conteúdo material da Constituição, possa se realizar uma análise crítica das justificativas utilizadas para embasar a tese da irresponsabilidade.

Não se desconsidera, porém, as dificuldades e os limites que o tema apresenta: a natureza impactante da responsabilidade do Estado Legislador, podendo mesmo, se feita de forma desarrazoada, conduzir à falência dos cofres públicos, à inviabilidade da modificação legislativa - dada a dificuldade de precisar a linha entre a necessária liberdade que deve ser conferida ao legislador e os limites, especialmente os materiais, que a ele se deve impor - sendo, por isso, questões que devem ser sopesadas para a configuração dos argumentos teóricos que subsidiam a construção jurídica em sentido reparatório.

Bem por isso, o presente trabalho pretende analisar, sem a pretensão de exaurir toda a controvérsia, algumas características que há de se reconhecer como necessárias ao desempenho da função legislativa, tal como a necessidade de conferir liberdade para o legislador acomodar o Direito às circunstâncias cambiantes, face ao postulado da segurança jurídica que deve permear o ordenamento com vistas a conferir-lhe estabilidade, 
como também os pressupostos da responsabilização, tais como a declaração de inconstitucionalidade da lei, a configuração do dano antijurídico, o nexo de causalidade.

O plano de trabalho está dividido em duas partes: a primeira refere-se ao tema geral da responsabilidade civil do Estado e a segunda trata do tema específico da responsabilidade civil do Estado Legislador nas hipóteses de lei inconstitucional e lei constitucional. Não será tratado o tema da responsabilidade civil do Estado pelas situações de omissão legislativa, seja ela constitucional ou inconstitucional, uma vez que a responsabilidade civil do Estado pela omissão encontra grandes divergências teóricas na doutrina e na jurisprudência, exigindo, por certo, um estudo aprofundado e específico, o que demandaria o desenvolvimento de outro trabalho.

No capítulo inicial da primeira parte, será analisado o conceito e a natureza jurídica da responsabilidade civil de modo geral para, em seguida, estudar as características peculiares da responsabilidade civil extracontratual aplicada ao Estado, especificamente, sua evolução, com as respectivas teorias desenvolvidas para explicá-la e fundamentá-la.

Passa-se, assim, desde a análise da época em que vigia a noção da completa irresponsabilidade estatal até culminar com o equacionamento da responsabilidade em termos objetivos, em que se prescinde da noção de culpa para sua atuação. Deixa-se claro, contudo, que a dispensabilidade de tal requisito para obrigar o Estado a responder com o seu patrimônio pelos danos que provoca não significa que ele tornou-se segurador universal de todo e qualquer prejuízo, dada a existência de hipóteses excludentes e atenuantes de responsabilidade.

No segundo capítulo analisam-se os aspectos teóricos da responsabilidade civil estatal no regime objetivo, que prescinde da culpa para sua atuação, diferenciando, especificamente, a responsabilidade do Estado por atos lícitos das situações em que a ordem jurídica confere ao Estado a prerrogativa de sacrificar legitimamente o direito alheio, ao que corresponde o dever de realizar, segundo o ordenamento pátrio, a conversão prévia de tal direito no seu equivalente patrimonial.

Delineiam-se as características do dano antijurídico desencadeador da responsabilidade, uma vez que não é qualquer prejuízo que implica reparação. Caracterizam-se, também, os sacrifícios de direito e o regime jurídico destes, sendo tal questão importante posto reconhecer-se, atualmente, que os sacrifícios não são mais apenas 
efetuados através de atos administrativos, mas também são concretizados por meio de atos legislativos, aos quais caberia, então, seguir o regime da previsão de prévia indenização, sob pena de gerarem um dano antijurídico, apto a fazer eclodir a responsabilidade civil estatal.

No terceiro capítulo serão expostos os elementos que compõem a responsabilidade civil do Estado no ordenamento jurídico brasileiro, sob o prisma do disposto no artigo 37, $\S 6^{\circ}$ da Constituição Federal, razão pela qual se analisará o seu conteúdo: atos comissivos ou omissivos, materiais ou jurídicos, lícitos ou ilícitos, dano, agente, terceiros, nexo causal.

Na segunda parte do trabalho, que trata especificamente da responsabilidade civil do Estado Legislador, será feita uma abordagem inicial sobre o objeto que pode ensejar a reparação: a função legislativa. Serão analisadas as construções jurídicas desenvolvidas ao longo da História que tentam explicar o conceito de lei, o que permitirá concluir, desde logo, acerca da impossibilidade de se falar, atualmente, num conceito unitário e universal de lei, demandando, portanto, a análise concreta da função legislativa em cada ordem jurídica, o que será feito neste estudo em relação ao ordenamento pátrio.

No segundo capítulo que integra esta parte do trabalho, serão apreciados, especificamente, os argumentos contrários à admissão da responsabilidade civil do Estado Legislador, contra cada qual serão tecidas críticas.

Após, admitida a possibilidade de responsabilização estatal por ato legislativo, serão abarcadas as duas hipóteses que se propôs tratar: atos legislativos inconstitucionais e constitucionais.

Quanto ao primeiro, será necessário compreender, inicialmente, acerca dos mecanismos de controle judicial de constitucionalidade das leis albergado no ordenamento, considerando que o tema influencia a argumentação jurídica desenvolvida pela doutrina, que reconhece que a lei inconstitucional apta a ensejar a responsabilidade é apenas aquela assim reconhecida através do controle concentrado. Observadas as tendências da jurisprudência relativas ao controle, será ponderado se ainda são pertinentes e adequadas as justificativas utilizadas para defender a referida posição. Também será analisada a necessidade ou não de prévia declaração de inconstitucionalidade para fins de responsabilidade, uma vez que o regime albergado no ordenamento pátrio não prescinde da ilicitude para responsabilização, possibilitando que o Estado responda pelo desempenho de 
atividades lícitas. Em razão também da prática pelo Supremo Tribunal Federal da modulação dos efeitos da inconstitucionalidade, será abordado de que forma o manejo de tais efeitos podem interferir no tema da responsabilidade civil estatal.

Em relação aos atos legislativos constitucionais, será intentado, inicialmente, compreender como uma lei que está em perfeita consonância com a Constituição pode ensejar a responsabilização do Estado. Para tanto, será relevada a consideração feita em relação aos atos lícitos, os quais, não obstante a possibilidade ou o dever de serem praticados, geram resultados antijurídicos. Contudo, será observado como ocorre a configuração deste dano antijurídico quando deslocada a análise para o âmbito legislativo, uma vez que nesses casos o parâmetro de antijuridicidade é extraído da Constituição. Serão analisadas quais das várias situações jurídicas do particular têm consistência suficiente para merecer a tutela reparatória, com enfoque para as situações em que houve a incorporação do direito ao patrimônio do particular (direito adquirido), bem como aquelas em que, embora não haja um direito do particular à manutenção do ato legislativo, existe uma expectativa, amparada pela boa-fé que o particular deposita na atividade estatal, que exigiria, se impossível a manutenção do comportamento do ente público, o pagamento de uma indenização pela sua extinção.

Será abordada também a possibilidade do legislador legitimamente vulnerar o direito que foi adquirido ou a expectativa legítima sem constituir danos que afrontem a ordem jurídica, ou sob outro ângulo, quais requisitos devem ser obedecidos para que o ato legislativo não cause um dano antijurídico. Dito de outro modo, quais exigências que uma vez desobedecidas geram a responsabilidade civil estatal e em que medida tal desobediência desloca a questão para uma hipótese de responsabilidade civil do Estado por lei inconstitucional.

Será examinada a posição do legislador frente a estas situações e problematizado de que forma a ausência de previsão de indenização no ato legislativo ou sua negação pode configurar obstáculo a tal pagamento.

Ao final, será tratada em linhas gerais a responsabilidade pessoal do legislador em virtude da edição de ato legislativo danoso, verificando se há possibilidade do Estado exercitar o direito de regresso do Estado em face do agente causador do dano. 
PRIMEIRA PARTE:

A RESPONSABILIDADE CIVIL DO ESTADO 


\section{RESPONSABILIDADE CIVIL DO ESTADO}

\subsection{CONCEITO E NATUREZA JURÍDICA}

O vocábulo responsabilidade advém do verbo responder, do latim respondere, tomado na significação de responsabilizar-se, vir garantido, assegurar, assumir o pagamento do que se obrigou ou do ato que praticou ${ }^{1}$. A essência da responsabilidade, ressalta Juary C. Silva, reside caracteristicamente no fato de alguém dever responder por algo feito ou omitido ${ }^{2}$. Edmir Netto de Araújo acentua que a conotação da palavra responsabilidade é sempre estabelecida com a idéia de imputabilidade a alguém, relativamente ao desequilíbrio que esse alguém causou na ordem regular ou natural das coisas $^{3}$.

Pode-se considerar instintiva a percepção acerca da necessidade de que alguém responda por uma ofensa praticada por um agente, sendo um pensamento moral comum àquele que diz ser adequado reparar um dano causado, reconhecendo-se ou fazendo ser reconhecida, portanto, a responsabilidade daquele que praticou o ato. Não se pode negar que, em qualquer forma de manifestação da atividade humana, seja no desempenho de uma tarefa profissional, no seio das relações familiares, no cumprimento de um contrato ou na prestação de um serviço público, encontra-se presente o fenômeno da responsabilidade, razão pela qual se pode afirmar que a responsabilidade é um fenômeno social e cotidiano.

Para o presente estudo importa, todavia, compreender como a responsabilidade é consagrada e regulada no âmbito jurídico, de modo que não serão discutidos os aspectos filosóficos, morais ou sociais que envolvem a questão ${ }^{4}$.

\footnotetext{
${ }^{1}$ SILVA, De Plácido e. Vocabulário Jurídico. 18. ed. Rio de Janeiro: Forense, 2001, p. 713.

2 SILVA, Juary C. A responsabilidade do Estado por atos judiciários e legislativos: teoria da responsabilidade unitária do poder público. São Paulo: Saraiva, 1985, p. 5.

${ }^{3}$ ARAÚJO, Edmir Netto de. Curso de Direito Administrativo. 4. ed. São Paulo: Saraiva, 2009, p. 740.

${ }^{4}$ Juary C. Silva ensina que embora seja bastante claro que o mecanismo de responsabilização se reveste de caráter social, o que lhe possibilita a atribuição do qualificativo de fenômeno cultural, tal não é suficiente para que adquira a conotação de mecanismo jurídico. A submissão de um agente que cometeu um ato danoso a uma determinada consequência não significa, automaticamente, a existência de uma sanção jurídica. Somente a reiteração e a uniformização da reação social aos atos danosos semelhantes é que cria um mecanismo sancionatório jurídico, isto é, objetivo, prévio e imparcial. SILVA, Juary C. Op.cit., pp. 6-7.
} 
Primeiramente há que se esclarecer que, de modo geral, o sentido da responsabilidade no âmbito jurídico não difere da própria noção de responsabilidade considerada in genere ${ }^{5}$. Como expõe De Plácido e Silva:

A responsabilidade (...) revela o dever jurídico, em que se coloca a pessoa, seja em virtude de contrato, seja em face de fato ou omissão, que lhe seja imputado, para satisfazer a prestação convencionada ou para suportar as sanções legais, que lhe são impostas.

Onde quer, portanto, que haja a obrigação de fazer, dar ou não fazer alguma coisa, de ressarcir danos, de suportar sanções legais ou penalidades, há a responsabilidade ${ }^{6}$. (grifos do autor)

Silvio Neves Baptista, focando seus estudos na responsabilidade civil ${ }^{7}$, afirma que o termo jurídico responsabilidade pode ser empregado em dois sentidos: ora para significar a obrigação de satisfazer ou executar ato jurídico (imputabilidade simples), ora para denotar a obrigação de ressarcir danos e sujeitar o infrator às sanções da lei ou do contrato (responsabilidade civil $)^{8}$. Tem-se nessas circunstâncias o responsável pela prática de determinado ato jurídico que, ao atuar de acordo com a norma, não está sujeito a responsabilidade civil e também a hipótese de alguma pessoa responsável por algum ato não cumprir com o dever imposto pela norma e, por isso, causar dano material ou moral a outrem, ocasião em que estará sujeito a responsabilidade civil, ou seja, será considerado obrigado a reparar o dano causado.

No ordenamento jurídico pátrio, a Constituição Federal de 1988 não deixa de utilizar o referido termo nesses sentidos e, ainda, em outros: referindo-se à consequência jurídica decorrente de um ilícito ${ }^{9}$, indicando a pessoa que pratica uma conduta ilícita ${ }^{10}$, distinguindo a pessoa que será sancionada pelo ilícito ${ }^{11}$.

\footnotetext{
${ }^{5}$ CRETELLA JÚNIOR, José. O Estado e a obrigação de indenizar. Rio de Janeiro: Forense, 1980, p. 10.

${ }^{6}$ SILVA, De Plácido e. Dicionário Jurídico. Rio de Janeiro: Forense, 2001, p. 713.

${ }^{7}$ Oportuno destacar que o Direito distingue diversas espécies de responsabilidade, estabelecendo para cada uma delas diferentes regimes. Tem-se a denominada responsabilidade civil ou patrimonial, que implica a obrigatoriedade do restabelecimento do equilíbrio econômico entre os patrimônios envolvidos na ação ou omissão que causou o desequilíbrio na ordem natural patrimonial; responsabilidade penal - quando a pessoa pratica um ilícito definido como ilícito penal, sujeitando-se, assim, às penalidades previstas nesse tipo de regime, como a imposição de uma pena privativa de liberdade ou medida de segurança; responsabilidade administrativa, quando ocorre a prática de um ilícito administrativo e o sujeito que o cometeu sofre as medidas administrativas necessárias ao restabelecimento da harmonia no âmbito interno da Administração Pública.

${ }^{8}$ BAPTISTA, Silvio Neves. Teoria geral do dano: de acordo com o novo Código Civil brasileiro. São Paulo: Atlas, 2003, p. 61.

${ }^{9}$ Confira-se, por exemplo, o artigo $5^{\circ}$, inciso XXXIII: "Todos têm direito a receber dos órgãos públicos informações de seu interesse particular, ou de interesse coletivo ou geral, que serão prestadas no prazo da lei, sob pena de responsabilidade, ressalvadas aquelas cujo sigilo seja imprescindível à segurança da sociedade $\mathrm{e}$ do Estado".
} 
Do ponto de vista da Teoria Geral do Direito - onde a responsabilidade melhor se aloca, tendo em vista tratar-se de tema de caráter fundamental para a ciência jurídica - no entanto, observa-se certa impropriedade em utilizar o termo para designar o sujeito que deve conduzir-se de determinada maneira (responsável), posto haver diferença conceitual entre a responsabilidade e a obrigação ou o dever jurídico. Socorrendo-se das lições de Kelsen ${ }^{12}$, apura-se que o dever jurídico corresponde à conduta cujo oposto é pressuposto de uma sanção. Em suas palavras: "Juridicamente obrigado está o indivíduo que, através da sua conduta, pode cometer o ilícito, isto é, o delito, e, assim, pode provocar a sanção, a consequência do ilícito - o delinquente potencial; ou o que pode evitar a sanção pela conduta oposta",

Assim, o indivíduo obrigado pode, pela sua conduta, provocar ou evitar a sanção ${ }^{14}$.

Já a responsabilidade, embora seja um conceito essencialmente ligado ao conceito de dever jurídico, com ele não se confunde. A responsabilidade não se constitui num dever, sendo a relação do indivíduo contra o qual o ato coercitivo é dirigido com o delito por ele ou por outrem cometido. $\mathrm{O}$ conceito de responsabilidade, assim, é direcionado àquele que sofre a sanção. Nas palavras do autor: "o indivíduo contra quem é dirigida a consequência do ilícito responde pelo ilícito, é juridicamente responsável por ele"15. Não há aî obrigação, mas sim sanção - que não pode ser impedida pelo próprio indivíduo - estatuída contra uma ação ou omissão determinada pela ordem jurídica. Resumindo: "É-se obrigado a uma conduta conforme ao Direito e responde-se por uma conduta antijurídica”"16.

A responsabilidade pode, ainda, abranger tanto conduta própria quanto alheia, diferentemente do que ocorre com a obrigação, que corresponde sempre à conduta da própria pessoa. Pode-se, assim, ser responsável pela conduta alheia, mas não se pode ser

${ }^{10}$ Brasil. Constituição Federal. Artigo $29-\mathrm{A}, \S 2^{\circ}$ : "Constitui crime de responsabilidade do Prefeito Municipal (...)". Artigo $29-\mathrm{A}, \S 3^{\circ}$. "Constitui crime de responsabilidade do Presidente da Câmara Municipal o desrespeito ao $\S 1^{\circ}$ deste artigo".

${ }^{11}$ Brasil. Constituição Federal. Artigo $5^{\circ}$, LXIX. "Conceder-se-á mandado de segurança para proteger direito líquido e certo, não amparado por 'habeas-corpus' ou 'habeas-data', quando o responsável pela ilegalidade ou abuso de poder for autoridade pública ou agente de pessoa jurídica no exercício de atribuições do Poder Público".

${ }^{12}$ KELSEN, Hans. Teoria pura do direito. Trad. João Baptista Machado. 6. ed. São Paulo: Martins Fontes, 1998, pp. 128-135.

${ }^{13}$ Ibidem, p. 130.

${ }^{14}$ Ibidem, p. 134.

${ }^{15}$ Ibidem, p. 134.

${ }^{16}$ Ibidem, p. 134. 
obrigado à conduta de outrem ${ }^{17}$, característica que também diferencia a responsabilidade do dever jurídico.

Do exposto, impende ressaltar que a própria noção de responsabilidade pressupõe a ocorrência de um ilícito, a desobediência de um dever jurídico, do qual decorra a incidência de uma sanção ${ }^{18}$. Avulta, nesse sentido, um caráter sancionatório atribuído à responsabilidade, pressupondo para sua eclosão a ocorrência do ilícito ${ }^{19}$.

A responsabilidade civil, modalidade de responsabilidade que surgiu no decorrer da História com a evolução do sistema de sanções aplicáveis, visa, através de um ato coercitivo, promover uma retirada compulsória do patrimônio daquele que é considerado responsável para, com a atribuição desse patrimônio ao lesado, restabelecer o equilíbrio econômico-jurídico alterado pela prática do ilícito. Por isso trata-se de uma modalidade de responsabilidade que não foge a esse caráter sancionatório. É o que salienta Maria Helena Diniz, ao anotar que o dano ensejador da responsabilidade (civil) sempre decorre da infração de um dever preexistente, de modo que a índole punitiva não lhe escapa ${ }^{20}$.

Tal natureza sancionatória não significa, como ressalta Juary C. Silva, que a responsabilidade civil seja um instrumento de vingança nem de sujeição do ofensor à pessoa do ofendido (ou de seus parentes). É, sim, um "instrumento técnico destinado a recompor o equilíbrio rompido pelo dano causado a alguém" ${ }^{21}$. Contudo, ressalta o autor que o fenômeno da responsabilidade civil se traduz, em termos práticos, na possibilidade de coerção, através do processo, o qual, por sua vez, constitui o conotativo indefectível do jurídico, distinguindo-o, assim, dos demais condicionamentos sociais ${ }^{22}$.

Sem dúvida de que a responsabilidade visa afastar o cometimento de um novo ilícito, primando pela manutenção da harmonia social. Mas há que se considerar também

\footnotetext{
${ }^{17}$ KELSEN, Hans. Teoria pura do direito. Trad. João Baptista Machado. 6. ed. São Paulo: Martins Fontes, 1998, p. 135.

18 ALMEIDA, Fernando Dias Menezes de. Responsabilidade extracontratual do Estado por atos lícitos: ensaio em homenagem a Guido Soares. In: CASELLA, Paulo Borba et al. Direito internacional, humanismo e globalidade. São Paulo: Atlas, 2008, p. 17

${ }^{19}$ Compreender a natureza jurídica da responsabilidade do Estado possibilita a delimitação de sua aplicação, ou seja, permite compreender em que casos se faz a aplicação do regime da responsabilidade, pois nem todas as hipóteses em que exista a obrigação de reparar ou efetuar um determinado pagamento configuram, exatamente, o fenômeno em questão.

${ }^{20}$ DINIZ, Maria Helena. Curso de Direito Civil Brasileiro. vol. 7. 24. ed. São Paulo: Saraiva, 2010, p. 8.

21 SILVA, Juary C. A responsabilidade do Estado por atos judiciários e legislativos: teoria da responsabilidade unitária do poder público. São Paulo: Saraiva, 1985, p. 15.

22 Ibidem, p. 29.
} 
que a responsabilidade civil, por abranger a reparação do dano causado pelo ato ilícito, contratual ou extracontratual, e por ato lícito, possui também uma função compensatória. $\mathrm{Na}$ medida em que pretende o pleno ressarcimento dos danos que o lesado sofreu, reconduzindo completamente a vítima à situação anterior à lesão (restabelecimento do statu quo ante), a responsabilidade civil visa garantir o direito do lesado à segurança. Por isso Maria Helena Diniz remete à dupla função da responsabilidade: a) garantir o direito do lesado à segurança; b) servir como sanção civil, de natureza compensatória, mediante a reparação do dano causado à vítima, punindo o lesante e desestimulando a prática de atos lesivos $^{23}$.

Atualmente, conforme expõe Josivaldo Félix de Oliveira, a responsabilidade civil pressupõe: "a individualização e a patrimonialidade da sanção; a proporcionalidade entre o dano e o ressarcimento; a verificação judicial do nexo de causalidade entre o ofensor e o dano; e o princípio do alcance do status quo ante, mesmo que aproximado"24.

Não é outra a característica da responsabilidade dita civil quando aplicada ao Estado, já que a responsabilidade é um fenômeno uno, em substância, em todos os ramos do Direito, pertencendo, como já se abordou acima, à Teoria Geral do Direito e não ao Direito Público ou ao Direito Privado ${ }^{25}$.

A atribuição da responsabilidade civil ao Estado corresponde, assim, à consequência de um ilícito praticado pelo Poder Público ${ }^{26}$, submetendo o Estado à excussão patrimonial, ou seja, possibilita ao lesado agredir o patrimônio público, para ver restaurada a harmonia social, desequilibrada pela ocorrência do prejuízo.

Todavia, como ressalta Celso Antônio Bandeira de Mello, embora hoje um dos pilares do moderno Direito Constitucional seja a sujeição de todas as pessoas, públicas ou privadas, ao quadro da ordem jurídica, de tal modo que a lesão aos bens jurídicos de terceiros engendre para o autor do dano a obrigação de repará-lo - o que faz com que a

${ }^{23}$ DINIZ, Maria Helena. Curso de Direito Civil Brasileiro. vol. 7. 24. ed. São Paulo: Saraiva, 2010, p. 9.

${ }^{24}$ OLIVEIRA, Josivaldo Félix de. A responsabilidade do Estado por ato lícito. São Paulo: Habeas Editora, 1998, p. 40.

${ }^{25}$ José Cretella Júnior muito bem esclarece essa questão no item 9 do Capítulo 1 de sua obra $O$ Estado e a obrigação de indenizar. Aduz que tanto a responsabilidade pública quanto a responsabilidade privada são duas espécies que pertencem ao gênero mais amplo - responsabilidade. Ocorre que, no mundo jurídico, a teoria da responsabilidade privada foi séculos antes elaborada pelos romanos, em comparação com a teoria da responsabilidade pública pelos modernos (1873, Caso Blanco, França). CRETELLA JÚNIOR, José. $O$ Estado e a obrigação de indenizar. Rio de Janeiro: Forense, 1998, p. 14 et. seq.

${ }^{26}$ Não se deve confundir desde já ilícito com conduta ilícita. O ilícito pode estar tanto na conduta como no resultado, tema que será abordado no decorrer do presente trabalho. 
responsabilidade se faça presente em todos os ramos do Direito -, é certo que a peculiaridade da posição jurídica do Estado, as funções que esse mesmo desempenha, obriga ao desenvolvimento de um regime de responsabilidade que lhe é próprio, mais extenso que o aplicado às pessoas privadas ${ }^{27}$. Nas palavras do autor:

Com efeito: seja porque os deveres públicos do Estado o colocam permanentemente na posição de obrigado a prestações multifárias das quais não se pode furtar, pena de ofender o Direito ou omitir-se em sua missão própria, seja porque dispõe do uso normal de força, seja porque seu contato onímodo e constante com os administrados lhe propicia acarretar prejuízos em escala macroscópica, o certo é que a responsabilidade estatal por danos há de possuir fisionomia própria, que reflita a singularidade de sua posição jurídica. Sem isto, o acobertamento dos particulares contra os riscos da ação pública seria irrisório e por inteiro insuficiente para resguardo de seus interesses e bens jurídicos. ${ }^{28}$

Nesse sentido, embora a responsabilidade civil estatal diferencie-se em determinados aspectos de outros tipos de responsabilidade albergadas pelo ordenamento jurídico, é certo que sua essência e natureza não deixam de corresponder à noção geral de responsabilidade elaborada pela Teoria Geral do Direito, não obstante seja possível notar, através da evolução do instituto em relação ao Estado, tema que será abordado nos próximos itens deste capítulo, que o desenvolvimento das teorias que o fundamentam atrela-se à evolução da própria concepção estatal ao longo da História.

\subsubsection{A nomenclatura adotada}

A expressão responsabilidade civil do Estado é assunto discutido pela doutrina que, temerosa da subsunção do Estado a um regime de Direito Privado, qualifica a responsabilidade estatal com outros termos: responsabilidade patrimonial do Estado ou responsabilidade extracontratual do Estado ou, simplesmente, responsabilidade do Estado.

Historicamente, tem-se que essa modalidade de responsabilidade foi assim adjetivada em virtude do grande desenvolvimento dos princípios fundamentais do instituto que se preordenou no campo do Direito Privado.

Essas diferentes terminologias são adotadas pelos estudiosos do tema, que justificam as suas escolhas de acordo com variados critérios. Cumpre destacar, ainda que

${ }^{27}$ MELLO, Celso Antonio Bandeira de. Curso de Direito Administrativo. 26. ed. São Paulo: Malheiros, 2009 , p. 988.

${ }^{28}$ Ibidem, p. 987. 
brevemente, esses posicionamentos, posto que eles se relacionam com o desenvolvimento do tema, mas, especialmente, com a justificativa do próprio título do presente trabalho.

No sentido da dispensabilidade da qualificação da responsabilidade estatal, há quem compreenda que essa só pode ser concebida como de natureza pecuniária, razão pela qual seria um pleonasmo adjetivá-la. É o posicionamento, por exemplo, de José Cretella Júnior, para quem "relativamente ao Estado só existe a responsabilidade civil, pois, como pessoa jurídica que é, o Estado é inimputável disciplinarmente e criminalmente" ${ }^{, 29}$.

Sob fundamento diverso, Elcio Trujillo também critica a utilização do adjetivo para qualificar a responsabilidade cabível ao Estado, já que tal qualificação poderia induzir à idéia de que a relação jurídica em questão seria regida pelo Direito Privado ${ }^{30}$.

Quanto ao primeiro posicionamento, ou seja, em relação à desnecessidade de qualificação da responsabilidade atribuída ao Estado, vale lembrar que a própria Constituição Federal consagrou no artigo $225, \S 3^{\circ}$ a hipótese de responsabilidade penal das pessoas jurídicas, possibilitando, assim, que o Poder Público também se submeta a uma responsabilidade de natureza penal, in verbis: “As condutas e atividades consideradas lesivas ao meio ambiente sujeitarão os infratores, pessoas físicas ou jurídicas, a sanções penais e administrativas, independentemente, da obrigação de reparar os danos causados”.

Nesse sentido, compreende-se que não mais subsiste a idéia de que as pessoas jurídicas estão sujeitas unicamente à responsabilização de natureza pecuniária, ou dita civil ou patrimonial, podendo, inclusive, sujeitarem-se à responsabilidade penal e/ou também administrativa, que preveem ilícitos distintos, além de consequências também diversas para a pessoa jurídica ou física que a tais regimes é submetida. Por isso, optou-se em incluir no título deste trabalho o qualificativo civil à responsabilidade do Estado, denunciando desde o início a opção em analisar apenas essa espécie de responsabilidade aplicada ao Estado.

Todavia, a fim de facilitar a leitura deste trabalho, ou seja, por mera opção de simplificação, referido adjetivo não foi utilizado em todas as referências à responsabilidade estatal feitas no texto, o que não significa, todavia, o acatamento de qualquer das teses acima expostas.

\footnotetext{
${ }^{29}$ CRETELLA JUNIOR, José. O Estado e a obrigação de indenizar. Rio de Janeiro: Forense, 1998, p. 27
}

30 TRUJILLO, Elcio. Responsabilidade do Estado por atos lícitos. São Paulo: Leud, 1996, p. 36. 
No tocante à crítica relativa à possibilidade de compreensão da responsabilidade estatal como tendo natureza civil em virtude da utilização do qualificativo, por certo que não se pode negar que, embora a origem da responsabilidade estatal remonte ao Direito Civil e tenha sido por ele influenciada durante longo período, isto não quer dizer, contudo, que dita responsabilidade não tenha assumido contornos próprios, no sentido de uma responsabilidade de caráter público, com princípios e regras diversas do regime aplicado no âmbito privado, razão pela qual a preocupação, por certo, parece demasiada, já que somente uma leitura precipitada e destituída de qualquer estudo poderia levar o intérprete a tal conclusão.

Ao longo da presente pesquisa, a afirmação acima se aclarará, especialmente quando do desenvolvimento do tema acerca da evolução da responsabilidade estatal, tratado a seguir, ocasião em que será possível vislumbrar o surgimento das diferenças entre os regimes de responsabilidade pública e privada.

\subsection{EVOLUÇÃO HISTÓRICA}

A responsabilidade civil do Estado ao longo da História tem sido estudada de acordo com numerosas teorias, as quais foram e ainda são elaboradas pela doutrina e jurisprudência para explicar e fundamentar o instituto da responsabilidade estatal. Observase, entretanto, que a evolução dessas teorias acompanha o desenvolvimento do conceito e da estrutura do próprio Estado de Direito, na medida em que a responsabilidade, por ser uma forma de garantir a invulnerabilidade dos direitos do indivíduo, evoluiu de acordo com a construção da noção de Estado como instrumento criado pelo indivíduo para realizar a justiça material.

Cabe, portanto, analisar tais teorias que são adotadas, preferencialmente, no sistema europeu-continental, especialmente porque elas influenciaram o tema da responsabilidade civil do Estado no Direito brasileiro.

Difícil é, no entanto, realizar um estudo estanque dos pressupostos dessas teorias, já que, muitas vezes, verificam-se pontos comuns entre elas, o que torna embaraçosa a diferenciação. Maria Sylvia Zanella di Pietro ${ }^{31}$ destaca que a dificuldade na sistematização do processo de evolução das teorias é marcada pela divergência terminológica adotada

${ }^{31}$ DI PIETRO, Maria Sylvia Zanella. Direito Administrativo. 22. ed. São Paulo: Atlas, 2009, p. 639. 
entre os autores, de modo que alguns chamam de culpa civil o que outros denominam culpa administrativa; outros ainda consideram hipóteses diversas a culpa administrativa $\mathrm{e}$ o acidente administrativo; e há aqueles que subdividem a teoria do risco em duas modalidades: risco integral e risco administrativo.

Entretanto, pondera Themístocles Brandão Cavalcanti ${ }^{32}$, que se deve recorrer ao traço predominante, ao fundamento doutrinário que caracteriza cada teoria, como forma de compreender sua importância para a matéria de responsabilidade do Estado.

De modo geral, pode-se sistematizar a evolução da responsabilidade civil aplicada ao Estado de acordo com as teorias que surgiram ao longo da História da seguinte forma: a) fase da irresponsabilidade ou teoria regaliana; b) fase civilista; c) fase publicista.

É oportuno ressaltar que o estudo da evolução das teorias permite perceber como o impacto das ideologias foi modelando e remodelando, historicamente, o Estado e suas relações com a sociedade e de que forma isso se refletiu nas alterações que, pouco a pouco, foram se concretizando nos regimes da responsabilidade civil.

Tal análise leva a compreender como o desvencilhamento da análise da culpa para justificar a responsabilidade estatal se aproxima da busca pela concretização de um modelo de Estado marcado pela idéia democrático-social, com a melhor proteção aos direitos dos cidadãos face às lesões ocasionadas pela atividade estatal comissiva ou omissiva.

\subsubsection{Fase da irresponsabilidade estatal ou teoria regalista}

À época dos Estados despóticos e absolutistas vigorava a noção de que o Estado era irresponsável pelos atos que cometia. Essa teoria se assentava sobre a máxima "the King can do no wrong” (o Rei não erra, ou não pode errar) ou "le Roi ne peut mal faire” (o Rei não pode fazer mal), já que o Rei era o próprio Direito e estava desvinculado do ato danoso causado pelo agente ${ }^{33}$.

O rei não cometia erros e, por conseguinte, não causava danos, já que era considerado o próprio representante de Deus na Terra.

\footnotetext{
${ }^{32}$ CAVAlCANTI, Themístocles Brandão. Tratado de Direito Administrativo. Vol. I. 5. ed. São Paulo - Rio de Janeiro: Freitas-Bastos, 1955, p. 372.

${ }^{33}$ ARAÚJO, Edmir Netto. Direito Administrativo. 4. ed. São Paulo: Saraiva, 2009, p. 745.
} 
O agente público, e não o Estado, era pessoalmente responsável por qualquer dano que provocasse, cabendo ao agente responder com seu patrimônio por tais danos, de modo que se fosse insolvente, restava frustrada a reparação.

Essa concepção chegou ao seu fim com o declínio do Estado absolutista, permanecendo, contudo, reinante nos Estados Unidos e na Inglaterra até que tais países, respectivamente, a extinguiram em 1946, por meio do Federal Tort Claim Act - que permitia a responsabilização do Estado em caso de culpa, apurada da mesma maneira e tão amplamente como a de um particular em iguais circunstâncias -, e em 1947, através do Crown Proceeding Act - ato pelo qual a Coroa passou a responder por danos causados por seus funcionários ou agentes, desde que houvesse infração daqueles deveres que todo patrão tem em relação aos seus prepostos e também daqueles deveres que toda pessoa comum tem em relação à propriedade ${ }^{34}$.

\subsubsection{Fase civilista}

A primeira teoria justificadora da responsabilidade estatal surgiu no final do século XVIII, com o fim da Revolução Francesa e o rompimento da forma autoritária de exercício do Poder Público. A ocasião exigia uma posição que não contrariasse os novos valores e princípios que floresciam no momento, mas que, igualmente, não permitisse uma integral indenização pelos danos causados, já que isto poderia conduzir à falência dos cofres públicos.

Daí surgiram as primeiras teorias civilistas da responsabilidade aplicada ao Estado, em cujo rótulo pode-se incluir aquelas que buscam na distinção dos atos estatais e na situação pessoal dos agentes a justificativa para determinação do dever de indenizar.

O grande passo dessas primeiras correntes foi romper com os tradicionais argumentos utilizados para justificar a irresponsabilidade absoluta do Estado, abrindo caminho, desta forma, para o desenvolvimento posterior de outras considerações que hoje mais se coadunam com a atual idéia de Estado de Direito.

\footnotetext{
${ }^{34}$ DI PIETRO, Maria Sylvia Zanella. Direito Administrativo. 22. ed. São Paulo: Atlas, 2009, p. 640.
} 


\subsubsection{Teoria dos atos de império e dos atos de gestão}

Aponta Carmen Lúcia Antunes Rocha ${ }^{35}$, inspirada nas lições de Léon Duguit, que havia duas idéias que se contrastavam na época do Estado Liberal: o dogma da propriedade privada, como valor absoluto, direito inviolável e sagrado do indivíduo, e o dogma da soberania do Estado e de sua inexpugnabilidade. No embate travado entre elas, pouco a pouco, cogitava-se de indenizações que tinham natureza reparatória.

Como saída jurídica para remediar essa situação, elaborou-se uma teoria baseada na classificação dos atos do Estado entre atos de império e atos de gestão para fins de responsabilidade. Segundo essa divisão, os atos de império seriam aqueles praticados sob o manto da Potestade Pública, como expressão do poder soberano que, nesta qualidade, pode impor medidas unilaterais e coercitivas, insuscetíveis, portanto, de gerar o direito à indenização, de forma que deveria a vítima conformar-se com os danos sofridos, uma vez que a ação ocorrera no interesse de todos.

Quanto aos atos de gestão, estes seriam aqueles realizados pelo Estado para satisfazer necessidades sociais e culturais, de progresso e de bem-estar. Nesses casos, agia o Estado em situação de igualdade com o particular, gerindo os interesses coletivos, administrando seu patrimônio como pessoa privada (fazendo contratos, alienações aquisições, etc.) e, nessa qualidade, com sua responsabilidade reconhecida.

Distinguia-se a pessoa do rei (insuscetível de errar), praticante dos atos de império, da pessoa do Estado, praticante dos atos de gestão por meio de seus prepostos e sujeito a responsabilização.

Entretanto, haveria que se demonstrar, juntamente com a prática do ato de gestão, a culpabilidade do funcionário na prática do ato danoso. O caráter culposo da conduta do agente era um fator condicionante da responsabilidade patrimonial do Estado, de modo a se compreender que somente com a comprovação da conduta ilícita do agente ou contrária ao Direito, hábil a ocasionar um dano a terceiro, ter-se-ia concretizado o pressuposto para a obtenção da reparação.

\footnotetext{
${ }^{35}$ ROCHA, Carmen Lúcia Antunes. Observações sobre a responsabilidade patrimonial do Estado. Rio de Janeiro, Revista Forense, Rio de Janeiro, n. 86, v. 311, pp. 3-25, ago./set. 1990, p. 9.
} 
Nesse contexto, uma vez configurada a culpa do agente em caso de lesão diante do exercício de um ato de gestão do Estado, o mesmo tornava-se responsável e obrigado a indenizar.

Entretanto, muitas críticas se levantaram com relação a tal divisão, haja vista a nem sempre tranquila diferenciação entre atos de império e atos de gestão, sendo comum a classificação de atos de uma noutra categoria ${ }^{36}$.

Themístocles Brandão Cavalcanti ${ }^{37}$ salienta, ainda, que tais divergências "baseiamse em uma divisão de personalidade do Estado, ou em uma distinção entre Estado e administração que, na realidade, não se coadunam com o princípio monista que caracteriza o Estado moderno". E conclui o autor que "não seria, além do mais, concebível um dualismo que conduziria o Estado, como expressão da coletividade, a indenizar pecuniariamente, os atos praticados pela administração, sem considerar Estado e administração como uma única expressão jurídica".

Dadas as críticas e as dificuldades de identificar casuisticamente os atos estatais que seriam de gestão, abandonou-se tal divisão, mas manteve-se a idéia de culpa, assim explicada pelo Direito Civil como critério apto a gerar o dever de indenização. Continuava o particular, deste modo, obrigado a comprovar o dano e o comportamento culposo do agente estatal, o que constituía, por vezes, um entrave à responsabilização do Estado, ante a dificuldade de demonstração de tal pressuposto.

\subsubsection{Teoria da culpa ou da responsabilidade subjetiva}

Nessa segunda fase ocorreu uma remissão aos fundamentos principiológicos embasadores da responsabilização por fato de terceiros então adotados pelo Direito Civil, ou seja, houve um alargamento (um empréstimo) da teoria da representação para abranger os entes públicos, de forma que o Estado passou a ser considerado como o patrão, tendo a mesma responsabilidade deste pela atuação dos seus agentes, os quais seriam meros representantes. Trata-se, assim, da assunção de uma forma de responsabilidade indireta pelo Estado.

\footnotetext{
${ }^{36}$ ARAÚJO, Edmir Netto. Curso de Direito Administrativo. 4. ed. São Paulo: Saraiva, 2009, p. 747.

${ }^{37}$ Cf. CAVALCANTI, Themístocles Brandão. Tratado de Direito Administrativo. vol. I. São Paulo - Rio de Janeiro: Freitas Bastos, 1955, p. 381.
} 
Por meio de tal entendimento, justificava-se a responsabilidade do Estado em caso de lesão ocasionada somente por culpa do agente público, a qual era presumida. Entretanto, dita responsabilidade poderia ser derrogada sempre que se provasse a ausência de culpa in vigilando (a Administração não pode ser responsabilizada uma vez cumpridas as exigências legais para a vigilância, verificação e controle das atividades de seus agentes) e de culpa in eligendo (a Administração não pode ser responsabilizada pela escolha de seus agentes, uma vez que, para nomear seus funcionários, é obrigada a cumprir determinações legais para o provimento). No caso de atos dolosos, estes eram atribuídos diretamente ao funcionário.

Entretanto, esta teoria também recebeu inúmeras críticas, já que o estabelecimento de condicionantes da conduta do agente para a recomposição do patrimônio lesado conduzia a subjetivismos tendentes a eximir o Estado da responsabilidade pelo dano.

Ademais, enquanto a teoria da culpa fundamentava-se em princípios privatísticos da relação patrão/empregado ${ }^{38}$, progressivamente se professava a necessidade de determinar a natureza da responsabilidade do Estado segundo princípios de Direito Público, atendendo às peculiaridades do Estado e das relações jurídicas em que figurava como parte.

Themístocles Brandão Cavalcanti ${ }^{39}$ justifica que a própria natureza do Estado, cuja missão social sobreleva a das demais entidades privadas, com sua estrutura própria de órgãos administrativos, justifica a necessidade de uma apreciação diferente do problema da responsabilidade civil do Estado que a consagrada pelo Direito Civil.

Nesse sentido, tanto a doutrina quanto a jurisprudência, e a própria legislação, inclinaram-se pela construção de uma responsabilidade fundada no Direito Público, o que permitiu ao instituto, posteriormente, ganhar foros de autonomia e diretrizes próprias, fora dos ditames do Direito Privado.

\footnotetext{
${ }^{38}$ Cabe ressaltar, ainda, conforme enumera Yussef Said Cahali, que também foram aplicados de forma analógica os princípios privatísticos da relação mandante/mandatário, preponente/preposto, representante/representado para definir a responsabilidade da pessoa jurídica, inclusive a do Estado, porém, nas palavras do autor, "nenhuma dessas se coadunaria com a vinculação estatutária do servidor ao órgão público". Cf. CAHALI, Yussef Said. Responsabilidade civil do Estado. 3. ed. São Paulo: RT, 2007, pp. 2324.

${ }^{39}$ CAVAlCANTI, Themístocles Brandão. Tratado de Direito Administrativo. vol. I. São Paulo - Rio de Janeiro: Freitas Bastos, 1955, p. 376.
} 


\subsubsection{Fase publicista}

A demanda por um Estado cada vez mais intervencionista, que corrigisse as desigualdades vigentes na época do Estado Liberal, atestou a insuficiência das teorias civilistas para solução dos danos ocasionados pelo Estado. Daí o surgimento das primeiras teorias publicísticas, destinadas a ampararem os particulares em face de um Estado que cada vez mais se imiscuía na esfera dos particulares.

O ápice do reconhecimento de que o regime jurídico a que o Estado encontrava-se sujeito deveria diferenciar-se do direito comum, então entendido como Direito Civil, ocorreu com o julgamento do caso "Blanco", em 1873, pelo Tribunal de Conflitos da França.

Tal decisão assentou que, a uma, a própria Administração Pública poderia ser responsabilizada por danos decorrentes de serviços por ela prestados e, a duas, que a norma civil não se aplicava a esse tipo de hipótese, devendo haver, portanto, autonomia jurídica da norma administrativa para o tratamento desses casos.

\subsubsection{Teoria da culpa administrativa}

A primeira construção jurídica que considerou a necessidade de distanciamento das normas civis do instituto da responsabilidade estatal foi a teoria denominada culpa administrativa, que, segundo Edmir Netto de Araújo ${ }^{40}$, representou o ponto de transição entre as idéias civilísticas e as doutrinas publicísticas.

Para essa corrente, os funcionários públicos não atuam como prepostos do Estado, numa relação de representante e representado, mas sim falam e agem em nome do Estado, com a autoridade pública que the confere sua competência legal. Deve-se imputar, assim, ao Estado, tanto a declaração de vontade do agente público, quanto a responsabilidade pela prática dos atos materiais dos agentes no exercício de suas atribuições.

Segundo José Joaquim Gomes Canotilho ${ }^{41}$, a configuração publicista da relação funcionário-Estado fornece o apoio para mais um passo na evolução no sentido de

\footnotetext{
${ }^{40}$ ARAÚJO, Edmir Netto de. Curso de Direito Administrativo. 4. ed. São Paulo: Saraiva, 2009, p. 748.

${ }^{41}$ CANOTILHO, José Joaquim Gomes. O problema da responsabilidade do Estado por actos lícitos. Coimbra: Almedina, 1974, pp. 47-48.
} 
responsabilizar o Estado, pois ocorre a transição de uma responsabilidade indireta para uma responsabilidade direta.

Tal teoria também estende o campo de incidência da responsabilização, pois passa a prever um alargamento da noção de culpa, com a inclusão do dolo e da imprevisão entre as suas modalidades.

Muito embora essa corrente denote um avanço, ela ainda continuava muito próxima da doutrina da indenização do dano por culpa do Direito Civil, porque só permitia a cominação da responsabilidade ao Poder Público quando seus órgãos ou representantes agissem culposamente, por ação ou omissão perante terceiros. Segundo Edmir Netto de Araújo $^{42}$, modificou-se apenas o fundamento da obrigatoriedade estatal de indenizar, que passou a ser o princípio (de Direito Público) da solidariedade patrimonial da coletividade frente ao ressarcimento do dano causado ao administrado.

Seguiu-se a evolução das teorias e da própria noção de culpa, pois se pugnava pela superação, por completo, dos cânones civilísticos, que se infiltravam na responsabilidade pública.

A partir daí, a culpa, então identificada, determinada e individualizada, foi sendo substituída pela noção publicística da culpa, o que significa dizer que ela passou a ser atribuída ao serviço - característica esta que se coaduna muito mais com a própria atividade estatal que, pelo fato de ser desempenhada através dos órgãos, possui, muitas vezes, um caráter impessoal.

\subsubsection{Teoria do acidente administrativo}

Essa nova acepção de culpa desenvolveu-se no bojo da primeira teoria da responsabilidade eminentemente objetiva do Estado: a teoria do acidente administrativo. Com a adoção dessa corrente, consagrou-se o julgamento do funcionamento do serviço público e não mais a verificação da conduta do agente, de modo que ao lesado cabe provar a anormalidade do funcionamento do serviço para ver sua pretensão acolhida pelos tribunais.

\footnotetext{
${ }^{42}$ ARAÚJO, Edmir Netto. Curso de Direito Administrativo. 4. ed. São Paulo: Saraiva, 2009, p. 749.
} 
A culpa do serviço, ou na expressão francesa onde se tem ainda uma vertente desse entendimento, a faute de service, se caracterizava pela anormalidade de um serviço público - o serviço público não funcionou, funcionou mal ou funcionou inoportuna ou intempestivamente -, ou seja, a culpa do serviço ocorria quando esse não funcionava em conformidade com o que deveria ser considerado normal pelas leis ou regulamentos que disciplinam essa atividade afeta à Administração.

Referida teoria, entretanto, não eximiu por completo o sentido da culpa para se apurar o dever de responsabilidade decorrente do serviço, pois para investigar o mau funcionamento ou o funcionamento retardado do serviço deveria ser levado em conta se os fatos poderiam ou não ser atribuídos aos funcionários ou se haviam sido ocasionados por algum motivo estranho, que tivesse ocorrido independentemente do Estado ter tomado a tempo as providências e medidas impostas pela situação.

Conforme pondera Themístocles Brandão Cavalcanti ${ }^{43}$ - que considera tal teoria uma espécie de teoria objetiva, "porque menos a culpa do que o funcionamento do serviço serve-lhe de base doutrinária" -, a "imperícia, a inércia, a negligência é que ocasionam o mau funcionamento do serviço, que não é autômato, mas que funciona através da atividade e da iniciativa dos funcionários".

Indiretamente, segundo o referido autor, para o estabelecimento da responsabilidade há que se indagar acerca da atitude do agente, na verdade, sobre a forma pela qual agiu o Estado, se tomou todas as medidas de precaução que estavam ao seu alcance, já que não é qualquer defeito no serviço que acarreta a responsabilidade, mas um certo grau de imperfeição ${ }^{44}$. Nesse sentido, consoante o entendimento do autor, não se permite um exame puramente objetivo do ato em relação ao evento danoso, já que para o estabelecimento da responsabilidade há que se responder a indagações que remetam à análise da culpa ${ }^{45}$.

\footnotetext{
${ }^{43}$ CAVALCANTI, Themístocles Brandão. Tratado de Direito Administrativo. vol. I. São Paulo - Rio de Janeiro: Freitas Bastos, 1955, pp. 409-410.

${ }^{44}$ Duez, Paul. De la responsabilité de la puissance publicque, p. 12. Apud CAVALCANTI, Themístocles Brandão. Tratado de Direito Administrativo. vol. I. São Paulo - Rio de Janeiro: Freitas Bastos, 1955, p. 409.

${ }^{45}$ CAVALCANTI, Themístocles Brandão. Op. cit., p. 409.
} 
Carmen Lúcia Antunes Rocha ${ }^{46}$ chega a tratar dessa teoria como uma espécie de teoria subjetiva. Afirma a autora que a noção de culpa possui um traço subjetivo que lhe é indelével. Logo, sem a comprovável ocorrência de um dos três elementos vinculados tradicionalmente ao conceito lato de culpa - negligência, imprudência, imperícia -, a entidade estatal poderia não ser necessariamente responsabilizada pela falta de um serviço público devido. Ausente, portanto, qualquer destes elementos caracterizadores da culpa, não haveria que se cogitar do fator subjetivo sem o qual não se sustentaria a responsabilidade do Estado.

O fato é que, embora não se aplicasse nos mesmos moldes a culpa de natureza civilista para reger a responsabilidade estatal, o dever de comprovar a falta do serviço para obter a indenização ainda constituía ônus excessivo para a vítima, principalmente em face do crescente intervencionismo estatal na vida dos cidadãos, o que demandava a necessidade de compreender o referido instituto através de uma perspectiva mais garantidora dos direitos dos indivíduos. Neste contexto, ao final do século XIX, os autores publicistas começaram a elaborar diversas razões para embasar uma responsabilidade totalmente desvinculada da idéia de culpa.

\subsubsection{Teoria do risco ou responsabilidade objetiva}

Muitos argumentos teóricos foram apontados pela doutrina para apoiar a adoção de uma responsabilidade objetiva do Estado. A teoria do Seguro Social, cujo principal defensor foi Leon Duguit ${ }^{47}$, sustenta que sempre que houvesse um dano ao administrado, o Estado ficaria obrigado a repará-lo, independentemente do serviço público ter funcionado normal ou anormalmente. A justificativa parte da idéia de segurança social, da construção de um patrimônio comum representado pelo Estado, que deve arcar com os riscos que podem decorrer das atividades do grupo.

\footnotetext{
${ }^{46}$ Cf. ROCHA, Carmen Lúcia Antunes. Observações sobre a responsabilidade patrimonial do Estado. Revista Forense, Rio de Janeiro, n. 86, v. 311, pp. 3-25, ago./set. 1990, pp. 10-11.

${ }^{47}$ Segundo Duguit: La actividad del Estado se pone en movimento por voluntades individuales. Pero es esencialmente colectiva por su fin, que es la organización y la gestión de los servicios publicos. Resulta de esto que si la organización y el funcionamiento de un servicio ocasionan a un grupo o a un individuo cargas excepcionales, un perjuicio particular, el patrimonio afectado a este servicio publico debe soportar la reparación del perjuicio, con la condición, sin embargo, de que haya una relación de causa o efecto entre la organización o el funcionamiento del servicio y el perjuicio. DUGUIT, León. Las transformaciones del Derecho Publico. (Traducción com estúdio preliminar de Adolfo Posada y Ramon Jaen). 2. ed. Madrid: Francisco Beltran, 1926. E também cf. DUGUIT, León. Traité de Droit Constitutionnel. T. III. 3. ed. Paris: Ancienne Librarie Fontemoing \& Cie., 1930, p. 469.
} 
Há também a idéia de sacrifício, elaborada por Otto Mayer ${ }^{48}$. Com base no princípio da equidade, quando um indivíduo fosse atingido por uma atividade estatal que acarretasse um prejuízo desigual e desproporcional em relação aos demais indivíduos, sob a forma de privação patrimonial, com um correspondente enriquecimento sem causa do Estado, ou seja, quando ocorresse um sacrifício especial, fosse a atividade lícita ou não, impunha-se ao Estado o dever de reparar o dano.

Uma outra teoria é fundada na igualdade de todos perante os encargos públicos, cujos melhores representantes foram Teissier e Tirard, conforme aponta Themístocles Brandão Cavalcanti ${ }^{49}$. Por meio dessa corrente, compreende-se que todos os cidadãos devem participar igualmente dos ônus dos serviços públicos, isto é, contribuir na medida de suas respectivas capacidades com os encargos de toda natureza. Os cidadãos não devem arcar uns mais que os outros com os encargos exigidos no interesse comum e, desta forma, o dano excepcional imposto ao particular deve ser suportado por todos. Michoud ${ }^{50}$ também $^{-1}$ argumenta nesse sentido, mas com algumas ressalvas, principalmente em relação aos atos que embora legais, por diversas circunstâncias, causem danos a terceiros.

Esses diferentes fundamentos contribuíram para a consolidação da corrente objetivista, construída, de modo geral, sob a idéia de risco da atividade estatal e da solidariedade patrimonial de todos os membros da coletividade frente ao prejuízo suportado por um determinado administrado em consequência da ação danosa de um agente público.

Surge, assim, a doutrina jurídica do risco administrativo, que pressupõe, para a configuração do dever de indenizar, apenas a ocorrência do nexo de causalidade entre o evento ocasionado ao particular e o comportamento do órgão ou agente do Estado que gerou, em virtude de sua atuação, um dano, impondo um gravame ao particular.

Tal teoria é denominada de risco administrativo pois leva em conta o potencial lesivo da atividade estatal, o risco de dano inerente da atividade governamental que, no desempenho da função pública, pode-se causar ao particular.

\footnotetext{
${ }^{48}$ Derecho administrativo alemán. (Tradução de Horário H. Heredia e Ernesto Krotoschin). vol. IV. Buenos Aires: Depalma, 1949, pp. 216-218. Apud FREITAS, Marisa Helena D’Arbo Alves de. Responsabilidade do Estado legislador. Franca: Unesp-FHDSS, 2001, p. 39.

${ }^{49}$ De la responsabilité de la puissance publique, p. 138. Apud CAVALCANTI, Themístocles Brandão. Tratado de Direito Administrativo. vol. I. São Paulo - Rio de Janeiro: Freitas Bastos, 1955, p. 411.

${ }^{50}$ La théorie de la personnalité morale, II, p. 270. Apud CAVALCANTI, Themístocles Brandão. Op. cit., p. 412.
} 
A noção de absoluta igualdade dos administrados diante dos ônus e encargos públicos também é considerada como idéia base da referida teoria. Quando uma pessoa sofre um ônus maior do que o suportado pelas demais, rompe-se o equilíbrio que necessariamente deve haver entre os encargos sociais e, para restabelecer esse equilíbrio, o Estado deve indenizar o prejudicado utilizando recursos do erário ${ }^{51}$.

Importa registrar que pela teoria do risco dispensa-se o cidadão de provar em juízo a culpa ou dolo do agente ou da Administração, já que sob essa vertente não se cogita da idéia de falta, senão da existência do dano e do nexo causal entre o prejuízo e a ação do Estado. Verifica-se, sem dúvida, maior agilidade na obtenção da indenização e, do mesmo modo, maior proteção dos direitos subjetivos e interesses legítimos do particular em face da ação estatal. Com a adoção dessa teoria, é possível afirmar que a necessidade de provar a falta do serviço foi substituída pela demonstração apenas e tão somente do fato do serviço como um dos critérios aptos a gerar o direito à indenização.

O dever de reparar o dano, na teoria objetiva, nasce independentemente da antijuridicidade da conduta, sendo devido tanto quando o prejuízo é decorrente da prática de um ato ilícito como de um ato lícito. Uma vez irrelevante a culpa, o que importa para gerar o dever indenizatório é a demonstração do efeito causado pelo ato ou omissão estatal ao particular, efeito esse que, repercutindo de tal forma a ponto de causar uma situação de desigualdade no direito ou no interesse legitimamente protegido daquele que o sofreu em comparação aos demais particulares ${ }^{52}$, obrigue o Estado a conceder ao prejudicado uma compensação patrimonial.

Maria Sylvia Zanella Di Pietro destaca que, no tocante a essa modalidade de responsabilidade, a idéia de culpa é substituída pela de nexo de causalidade entre o funcionamento do serviço público e o prejuízo sofrido pelo administrado. É indiferente, portanto, que o serviço público tenha funcionado bem ou mal, de forma regular ou irregular $^{53}$.

${ }^{51}$ DI PIETRO, Maria Sylvia Zanella. Curso de Direito Administrativo. 22. ed. São Paulo: Atlas, 2009, p. 642.

${ }^{52}$ Vale ressaltar que esse seria um dos fundamentos para justificar a teoria da responsabilidade do Estado de moldes objetivos, havendo, como já se expôs acima, outros fundamentos aptos a desencadeá-la.

${ }^{53}$ DI PIETRO, Maria Sylvia Zanella. Curso de Direito Administrativo. 22. ed. São Paulo: Atlas, 2009, p. 642. 
No mesmo sentido, Yussef Said Cahali entende acertada a posição da doutrina e da jurisprudência mais atualizadas quando, na perquirição da responsabilidade objetiva do Estado, dão ênfase ao elemento concreto da causalidade entre o dano injusto sofrido pelo particular e a atividade comissiva ou omissiva do ente público ${ }^{54}$.

Cabe ressaltar, todavia, que a dispensa na perquirição da culpa não se traduziu na admissão de uma responsabilidade estatal de forma irrestrita, já que isso, por certo, conduziria à própria inviabilidade da atuação do Estado. Com a ênfase na causalidade, a exclusão ou atenuação do dever indenizatório passaram também a orbitar sobre o exame dos fatores que ocasionam o dano, de modo que são as hipóteses de quebra do nexo de causalidade que mitigam a responsabilidade.

Assim, nos casos em que houver culpa total do lesado no evento ou, ainda, quando o fato decorrer de culpa de terceiro ou de força maior afasta-se a reparação, enquanto que, nos casos em que houve culpa concorrente da vítima, tal obrigação encontra-se amenizada.

A culpa do próprio prejudicado ou de um terceiro, quando comprovada, bem como as hipóteses de força maior, por interferirem diretamente no nexo de causalidade que liga o ato praticado pelo Estado ao dano, afastam a responsabilidade estatal.

$\mathrm{Na}$ doutrina, todavia, há autores que defendem a existência da teoria do risco integral, segundo a qual não haveria campo para a indagação a respeito da culpa concorrente ou de outros fatores excludentes da responsabilidade. Para Hely Lopes Meirelles $^{55}$, essa teoria seria a modalidade extremada da teoria do risco, pois não admitiria as excludentes de responsabilidade: culpa da vítima, culpa de terceiro ou força maior. Bastaria o simples liame de causalidade entre o dano e o ato ou omissão estatal para configurar-se a obrigação estatal de reparar, ainda que o dano tenha sido provocado pela própria vítima.

Na verdade, conforme aduz Eliana Bueno de Miranda Santos ${ }^{56}$, a teoria do risco integral não tem por pressuposto o nexo causal, sendo esse dispensável de prova.

\footnotetext{
${ }^{54}$ CAHALI, Yussef Said. Responsabilidade civil do Estado. 3. ed. São Paulo: RT, 2007, p. 42.

55 MEIRELLES, Hely Lopes. Direito Administrativo brasileiro. 35. ed. (Atualizada por Eurico de Andrade Azevedo, Délcio Balestero Aleixo e José Emmanuel Burle Filho). São Paulo: Malheiros, 2009, p. 658.

${ }^{56}$ SANTOS, Eliana Bueno de Miranda. Responsabilidade civil do Estado por atos legislativos. São Paulo: SRS Editora, 2008, p. 64.
} 
Entretanto, a maior parte dos autores considera a discussão entre risco administrativo e risco integral meramente acadêmica, adotando as duas posições como sinônimas $^{57}$. Nesse sentido é o posicionamento de Edmir Netto de Araújo ${ }^{58}$, para o qual mesmo os autores do risco integral admitem as excludentes de responsabilidade, de modo que as duas teorias, risco integral e risco administrativo, refletem o mesmo por outras palavras.

É por isso que Yussef Said Cahali pondera, analisando a responsabilidade albergada pelo ordenamento jurídico pátrio na Constituição de 1988, cujas considerações acolhem-se neste estudo, que:

Na realidade, qualquer que seja o fundamento invocado para embasar a responsabilidade objetiva do Estado (risco administrativo, risco integral, risco-proveito), coloca-se como pressuposto primário da determinação daquela responsabilidade a existência de um nexo de causalidade entre a atuação ou omissão do ente público ou de seus agentes, e o prejuízo reclamado pelo particular.

Trata-se de questão de fato a ser investigada em cada caso concreto, de modo que, demonstrado o referido nexo, surge a obrigação de indenizar, sendo indevida esta se ausente sua demonstração ${ }^{59}$.

Desse modo, qualquer das teorias que fundamentem a responsabilidade de índole objetiva, cuja consagração adveio da evolução histórica da própria noção de responsabilidade, é certo que ela não conduzirá o Estado a responder por todo e qualquer evento, por outro lado, não prescindirá da demonstração da culpa, ainda que anônima, para sua atuação ${ }^{60}$.

Sobre a responsabilidade vigente atualmente no ordenamento jurídico brasileiro, serão feitas, ainda, considerações específicas no capítulo 3 do presente trabalho, cabendo apenas ressaltar, neste momento, que o ordenamento em vigor, acompanhando o desenvolvimento do instituto da responsabilidade civil estatal, consagra hoje que tal responsabilidade é, em regra, objetiva para o Estado, facilitando ao particular a obtenção do ressarcimento dos danos causados pelo Poder Público.

\footnotetext{
${ }^{57}$ Cite-se, por exemplo, a posição de DI PIETRO, Maria Sylvia Zanella. Curso de Direito Administrativo. 22. ed. São Paulo: Atlas, 2009, p. 643 e também CAHALI, Yussef Said. Responsabilidade civil do Estado. 3. ed. São Paulo: RT, 2007, pp. 40-41.

${ }^{58}$ ARAÚJO, Edmir Netto. Curso de Direito Administrativo. 4. ed. São Paulo: Saraiva, p. 752.

${ }^{59}$ CAHALI, Yussef Said. Responsabilidade civil do Estado. 3. ed. São Paulo: RT, 2007, p. 44.

${ }^{60}$ Ressalve-se, contudo, as divergências doutrinárias e jurisprudenciais relativas à responsabilidade civil do Estado nos casos de omissão, hipóteses em que para alguns a responsabilidade seria subjetiva. O tema será tratado mais adiante neste trabalho.
} 


\subsection{EXCLUDENTES E ATENUANTES DA RESPONSABILIDADE OBJETIVA}

Como afirmado, a adoção da responsabilidade civil estatal em termos objetivos não implica responsabilização irrestrita do Poder Público, mas significa que a vítima fica dispensada de provar a culpa do Estado para a reparação do dano. Há causas, no entanto, que excluem essa responsabilidade, pois interferem no nexo causal que liga a conduta do agente público ao resultado danoso.

O comportamento da vítima pode levar tanto à exclusão da responsabilidade estatal como a sua atenuação, devendo ser apurado no caso concreto como o seu envolvimento na situação lesiva concorreu para o resultado. Se não foi o Estado quem causou o resultado, através da ação ou omissão do agente público, e sim a vítima, através de sua conduta culposa, não cabe ao ente estatal a responsabilização pelos prejuízos.

Cabe ao Estado, contudo, provar a existência da culpa exclusiva ou concorrente da vitima, cuja conduta interferiu no nexo de causalidade entre a atuação ou omissão de seus agentes e o prejuízo reclamado pelo particular.

Do mesmo modo, a responsabilidade civil estatal pode ser excluída ou atenuada quando a culpa não é da vítima, mas de um terceiro estranho à relação Estado-particular. Acaso isso seja possível, o que remete à análise dos cuidados que são exigíveis do ente público em determinada situação concreta, não caberá o afastamento ou a minoração da responsabilidade estatal.

As hipóteses de força maior - tais como fatos da natureza: raios, terremotos, erupções vulcânicas - também são comumente denominadas de causas excludentes da responsabilidade. São situações de força maior, conforme ensina Edmir Netto de Araújo, aquelas que possuem uma causa conhecida, mas impossível de ser contida pela potencialidade humana, sendo por isso irresistíveis, inelutáveis ${ }^{61}$.

Daí que por exorbitarem a atuação estatal, situando-se em forças incontroláveis da natureza, não há nexo causal entre a conduta do ente público e o dano produzido, razão pela qual a situação não induz à responsabilidade objetiva do Estado.

\footnotetext{
${ }^{61}$ ARAÚJO, Edmir Netto de. Curso de Direito Administrativo. 4. ed. São Paulo: Saraiva, 2009, p. 755.
} 
Diferente ocorre com as circunstâncias que caracterizam caso fortuito, as quais, em relação ao Estado, referem-se ao próprio funcionamento do serviço público. Nessas situações a causa do dano é desconhecida, permanecendo ignorado como o evento foi produzido.

As hipóteses de força maior inserem-se no risco assumido pelo Estado ao desempenhar seus serviços, isto é, o Estado assume o risco de que ocorra, por exemplo, uma falha mecânica no seu aparelhamento que venha a prejudicar o administrado ${ }^{62}$. Não se trata de uma circunstância alheia ao desempenho das atividades do Estado, um fato da natureza, razão pela qual resta estabelecido o nexo causal entre o evento danoso e a atuação do Poder Público.

Daí que, nessas hipóteses, não se vislumbra uma excludente ou atenuante de responsabilidade, devendo o ente público, dado o risco que assumiu ao prestar aquele serviço, responder pelo acidente, caso fortuito, ocorrido.

\footnotetext{
${ }^{62}$ Cf. ARAÚJO, Edmir Netto de. Curso de Direito Administrativo. 4. ed. São Paulo: Saraiva, 2009, p. 756
} 


\section{ASPECTOS TEÓRICOS DA RESPONSABILIDADE CIVIL OBJETIVA DO ESTADO}

\subsection{A ABRANGÊNCIA DE ATOS LÍCITOS E ILÍCITOS}

O desenvolvimento da responsabilidade estatal em termos objetivos possibilitou ao particular uma ampliação da proteção aos seus direitos, na medida em que para obter o direito à indenização em razão do desempenho da atividade estatal não era mais necessário provar a existência do elemento culposo na conduta do agente, bastando para tanto a demonstração da efetivação de um ato estatal, da concretização de um dano e do nexo de causalidade entre eles.

Com a desnecessidade da análise da culpa, o respaldo da obrigação de indenizar foi deslocado da ilicitude do ato, ou seja, da prática do ato, para a análise do efeito que produz, na medida em que se passa a questionar os efeitos do ato sobre um ou alguns particulares diante dos demais.

Essa prescindibilidade, que caracteriza a citada modalidade de responsabilidade, conduziu o foco da investigação a respeito dos pressupostos do dever de indenizar da atitude do agente público para a situação sofrida pelo particular. O que interessa para a aplicação do instituto é o efeito causado pela conduta - o dano - independentemente de este ter sido provocado por ato lícito ou ilícito.

Com isso, o comportamento estatal do qual decorreu o dano pode até ser, e muitas vezes o é, efetivamente, reprovável, censurável, inválido juridicamente; outras vezes não, nada disto muda a indispensabilidade e a extensão do princípio da responsabilidade, pois não se busca por esta figura meramente a reprovação da conduta do Estado, mas também se quer a proteção do indivíduo, o respeito a sua esfera de proteção e, consequentemente, sua segurança, o restabelecimento da normalidade violada pela ocorrência da lesão.

Weida Zancaner ${ }^{63}$ explica que:

A importância do deslocamento da ilicitude da conduta do agente (e, portanto, da culpa), para a lesão antijurídica do patrimônio, teve tão funda

\footnotetext{
${ }^{63}$ BRUNINI, Weida Zancaner. Da responsabilidade extracontratual da Administração Pública. São Paulo:
} Revista dos Tribunais, 1981, p. 42. 
significação para a imputação da responsabilidade ao Estado, que alguns doutrinadores não hesitaram em entrever nesta teoria uma revolução copernicana no instituto da responsabilidade do Estado, visto por ela compreender que o sol que ilumina a responsabilidade é o dano e não, como se pensava, a conduta do agente.

O entendimento neste estudo é de que essa modificação do centro da responsabilidade se adequa, inclusive, à própria finalidade perseguida pelo instituto, que é a proteção da esfera juridicamente protegida do particular contra a atuação exógena, de modo que deve ser a afetação dessa situação juridicamente protegida o fato gerador da responsabilidade.

Edmir Netto de Araújo ressalta que, em face desta perspectiva:

(...) para fins de responsabilidade civil do Estado, a caracterização de um ato, jurídico ou material, como ato ilícito, já teve mais importância que atualmente: com efeito é mais lógico e mais fácil atribuir-se a responsabilidade quando o comportamento ou omissão danosos tenham sido ilícitos (...). No entanto, a adoção, a partir da Constituição de 1946, da teoria objetiva do risco (integral ou administrativo, que para nós é o mesmo), deslocou o respaldo da obrigação de indenizar do Estado para os ditames da teoria da solidariedade patrimonial da coletividade frente ao dano sofrido por certo administrado ${ }^{64}$.

Entretanto, esse deslocamento não importa na total desconsideração da ilicitude ou licitude do ato, como propugnam alguns autores ${ }^{65}$, mas sim em um abrandamento da distinção, dada a acentuação que se dá em relação ao efeito lesivo produzido. Isso porque, apurando-se que se trata de dano proveniente de ato ilícito, poderá o Estado exercer seu direito de regresso contra o agente causador do dano, enquanto que, tratando-se de ato lícito, tal não poderá ocorrer ${ }^{66}$.

Mas ainda que não seja de todo despiciendo saber se o dano provém de um ato lícito ou ilícito, com base nesse pensamento o que mais importa conhecer - o pressuposto para atuação do instituto - é a consequência da conduta comissiva ou omissiva do agente

\footnotetext{
${ }^{64}$ ARAÚJO, Edmir Netto de. Curso de Direito Administrativo. 4. ed. São Paulo: Saraiva, 2009, p. 763.

${ }^{65}$ Weida Zancaner Brunini destaca que, para uma determinada corrente, na qual se inclui García de Enterría, não haveria que se distinguir entre atos lícitos e ilícitos, podendo ambos ser equiparados. A autora ressalta que "para essa teoria, nenhum dano deve ser suportado pelos particulares, devido ao princípio da igualdade dos administrados perante os encargos públicos. Essa corrente doutrinária fez tábula rasa desse princípio, proporcionando ao administrado possibilidade de pleitear ressarcimento, mesmo que o dano seja originário de atividade lícita do Estado e de valor ínfimo. O que importa é poder apurar-se pecuniariamente o dano, e sendo este antijurídico (antijurídico na generosa acepção dessa doutrina), o Estado tem a obrigação de indenizar". BRUNINI, Weida Zancaner. Op. cit., pp. 43-44.

${ }^{66}$ Como se verá adiante neste trabalho, a distinção entre atos lícitos e ilícitos também é importante, na medida em que, em razão de cada qual deles, modificam-se as características do dano que enseja a responsabilidade.
} 
público: se ela (consequência) é ou não um dano juridicamente reconhecido. É o que explica Edmir Netto de Araújo:

A responsabilidade do Estado por ato lícito é tema que vem sendo cada vez mais versado na doutrina brasileira, sempre no sentido de que independe a responsabilidade da ilicitude dos atos, porque decorre fundamentalmente do dano e do consenso que o respectivo prejuízo deve ser repartido entre a coletividade (justiça social e equidade), elementos que lastreiam a teoria objetiva 'sem culpa' da responsabilidade do Estado. $^{67}$

Sabe-se que só haverá responsabilidade, tanto em face da teoria subjetiva como da objetiva, se houver dano a reparar. A ocorrência do dano é pressuposto para o nascimento da responsabilidade. Mas ainda que tanto numa como noutra teoria esse pressuposto não seja dispensável, tem-se que na teoria objetiva o dano, ou seja, a situação fática produzida pelo ato é o fato gerador da responsabilidade, diferente do que ocorre com a teoria subjetiva, que depende da demonstração da culpa para sua atuação.

Assim, na teoria objetiva, voltam-se as luzes para o dano ocorrido, que deve ser de tal forma que mereça uma censura da ordem jurídica através da retirada compulsória do patrimônio estatal para atribuí-lo ao lesado (responsabilidade civil). É essa situação fática e não a culpa do agente ou do serviço - que, a depender das características que apresenta, fará nascer uma hipótese autorizadora da responsabilidade civil do Estado.

Porém é necessário salientar que, em se tratando de uma responsabilidade tal como definida pela ordem jurídica, é esta última que apresenta as características do dano apto a atuação do instituto, não sendo qualquer lesão econômica ou material suficientes para tanto. Somente a lesão patrimonial que afronta algo que é amparado pelo sistema jurídico faz nascer o direito ao ressarcimento. Nas palavras de Eduardo Garcia de Enterría e Tomás-Ramón Fernández, o dano que gera a responsabilidade é, portanto, um dano antijurídico $^{68}$.

Em sendo um dano antijurídico - e não meramente econômico - o elemento desencadeador da responsabilidade, ou seja, um resultado ilícito tal como definido pela ordem jurídica, logo se conclui que o elemento ilicitude, atrelado ao próprio conceito de responsabilidade, sempre terá que estar presente no resultado. Concorda-se, assim, com o pensamento de Fernando Dias Menezes de Almeida, ao dizer que a ilicitude não

${ }^{67}$ ARAÚJO, Edmir Netto de. Curso de Direito Administrativo. 4. ed. São Paulo: Saraiva, 2009, p. 763.

${ }^{68}$ Cf. ENTERRÍA, Eduardo García de. FERNÁNDEZ, Tomás-Ramón. Curso de Derecho Administrativo. vol. II. 9. ed. Madrid: Civitas, 2004, pp. 378-379. 
necessariamente precisa estar na ação ou omissão estatal - de modo que o ato pode ser lícito ou ilícito - devendo sim situar-se no resultado que o ato provoca ${ }^{69}$.

Admite-se, assim, ainda que o Estado adote as diligências necessárias para evitar a ocorrência do dano, atuando licitamente, em obediência a todos os parâmetros estabelecidos pela ordem jurídica, em determinados casos não é possível prever e evitar a ocorrência de um dano antijurídico para este ou aquele particular. Pode ser faticamente impossível individualizar previamente uma determinada pessoa que poderia sofrer com tal ato. Daí não ser admissível deixar algum particular ou um grupo deles sofrer uma oneração maior, imposta pelo Estado para realização do bem comum, somente porque este tomou todas as precauções cabíveis e que eram possíveis naquele momento. Se o resultado revelou apenas posteriormente a ocorrência injustificada de encargos desiguais decorrentes do ato, não se pode eximir o Estado da responsabilidade, razão pela qual não apenas a conduta, mas também - e principalmente - o resultado deve ser levado em consideração como forma de aferir a antijuridicidade que configura a responsabilidade.

Dos ensinamentos de Celso Antônio Bandeira de Mello ${ }^{70}$, especialmente no que se refere à diferença de fundamentos que embasam a responsabilidade quanto a atos lícitos ou ilícitos, vislumbra-se que a antijuridicidade sempre está presente para fundamentar a responsabilidade, na conduta e no resultado ou apenas no resultado, como propõe o autor:

a. No caso de comportamentos ilícitos comissivos ou omissivos, jurídicos ou materiais, o dever de reparar o dano é a contrapartida do princípio da legalidade. Porém, no caso de comportamentos ilícitos comissivos, o dever de reparar já é, além disso, imposto também pelo princípio da igualdade.

b. No caso de comportamentos lícitos, assim, como na hipótese de danos ligados a situação criada pelo Poder Público - mesmo que não seja o Estado o próprio autor do ato danoso -, entendemos que o fundamento da responsabilidade estatal é garantir uma equânime repartição dos ônus provenientes de atos ou efeitos lesivos, evitando que alguns suportem prejuízos ocorridos por ocasião ou por causa de

\footnotetext{
69 ALMEIDA, Fernando Dias Menezes de. Responsabilidade extracontratual do Estado por atos lícitos: ensaio em homenagem a Guido Soares. In: CASELLA, Paulo Borba et al. Direito internacional, humanismo e globalidade. São Paulo: Atlas, 2008, p. 15.

${ }^{70}$ MELlo, Celso Antonio Bandeira de. Curso de Direito Administrativo. 26. ed. São Paulo: Malheiros, 2009, p. 997.
} 
atividades desempenhadas no interesse de todos. De conseguinte, seu fundamento é o princípio da igualdade, noção básica do Estado de Direito. (grifos do autor)

Nota-se, segundo esse parâmetro, que ora a responsabilidade decorre porque há afronta à legalidade, ora porque a conduta estatal causa uma consequência que fere a isonomia, na medida em que não garante uma repartição equânime dos encargos públicos entre os particulares. De qualquer forma, há sempre uma afronta à ordem jurídica, especialmente ao consagrado na Constituição Federal: ou o ato é ilícito e enseja a responsabilidade ou, sendo o ato lícito, o resultado produzido fere o ordenamento jurídico infringindo a isonomia e então configura a inexistência do dever legal do ofendido suportar uma determinada consequência da atividade estatal.

O dano antijurídico é que delimitará, portanto, a aplicação do instituto da responsabilidade. Nesse sentido, cabe tecer considerações sobre a as características desse pressuposto como meio apto a gerar a responsabilidade.

\subsubsection{A ilicitude do resultado: o dano antijurídico}

Conforme aduzido acima, não é qualquer dano que sujeita o Estado à responsabilidade civil, posto que a admissão dessa tese implicaria conceber o Estado como segurador universal, já que deveria responder por qualquer prejuízo econômico que causasse, independentemente de ser uma lesão contrária à ordem jurídica. Somente o prejuízo patrimonial traduzido em dano qualificado como dano antijurídico gera a responsabilidade.

Celso Antônio Bandeira de Mello ${ }^{71}$, ao elaborar as premissas que caracterizam o dano suscetível de gerar o direito à reparação, destaca a necessidade da existência concomitante de duas delas, quais sejam:

a. o alcance de uma situação jurídica legítima, suscetível de configurar um direito, ou quando menos, um interesse legítimo. Neste caso, sustenta o autor a importância de se distinguir o dano econômico do dano jurídico, posto que apenas este último, que consagra, para além da diminuição econômica, um bem a que se faz jus, algo que a ordem jurídica considera como pertinente ao lesado, enseja reparação;

\footnotetext{
${ }^{71}$ MELlo, Celso Antônio Bandeira de. Curso de Direito Administrativo. 26. ed. São Paulo: Malheiros, 2009, p. 1010 et seq.
} 
b. $\quad$ o dano deve ser certo e não eventual, podendo ser atual ou futuro.

A certeza do dano caracteriza-se pela sua real existência, ainda que os seus efeitos se operem na atualidade ou apenas futuramente. É certo o dano quando, numa situação concreta, não se tem apenas uma mera hipótese de ocorrência, sabendo-se que ele será inevitável e virá a se concretizar.

Embora essas características devam estar presentes tanto nas hipóteses de atos lícitos como ilícitos praticados pelo Estado para gerar o direito ao ressarcimento, segundo o entendimento do autor ${ }^{72}$, ambos os requisitos seriam suficientes para caracterizar o dano indenizável nos casos de lesão por comportamentos ilícitos, quer sejam atos ou fatos, comissivos ou omissivos.

Entretanto, nos casos de atos lícitos haveria, ainda, cumulada com essas características, a necessidade de demonstrar a especialidade (o dano é relativo a uma pessoa ou a um grupo de pessoas) e a anormalidade (o dano excede aos incômodos provenientes da vida em sociedade $)^{73}$, dado que não se poderia conceber qualquer ato lícito gerando responsabilidade estatal, sob pena de inviabilizar-se a própria existência do Estado $^{74}$.

O dano especial caracteriza-se pela contraposição à idéia de dano universal, que é suportado por todos os particulares indistintamente. $\mathrm{O}$ dano universal pode ser considerado uma carga pública a ser suportada por todos como decorrência inerente à vida em sociedade. Já o dano especial fere o princípio da igualdade, posto que ocasiona uma diferença de encargos entre os particulares para efetivação do bem comum, razão pela qual enseja a responsabilidade.

O dano anormal é definido como aquele que excede aos incômodos provenientes da vida em sociedade, ou seja, trata-se de um encargo que extrapola aquilo que normalmente se suporta por viver em sociedade. Os danos normais, os sacrifícios diminutos, de pouca importância, que constituem encargos sociais, seriam compensados por vantagens de outra ordem, provenientes da atuação da máquina estatal. O limiar entre aquilo que se pode chamar de encargo normal da vida em sociedade e o que se qualifica como dano grave, de

\footnotetext{
${ }^{72}$ Ibidem, p. 1012.

${ }^{73}$ Ibidem, p. 1013.

${ }^{74}$ SILVA, Almiro do Couto e. A responsabilidade extracontratual do estado no direito brasileiro. Revista de Direito Administrativo, Rio de Janeiro, n. 202, pp. 19-41, out./dez. 1995, p. 36.
} 
acordo com o exposto, adviria da aplicação do princípio da razoabilidade, de modo que afetações não razoáveis a bens, direitos ou atividades podem gerar pretensões de ressarcimento.

Weida Zancaner Brunini ${ }^{75}$, embora acolha essa distinção de características relativas ao dano indenizável, afirma que, na verdade, esses traços compõem a noção de antijuridicidade do dano - que para essa autora é espécie de injustiça - a qual é sim causa de imputação de responsabilidade ao Estado.

Contudo, nem todos os autores acolhem essas distinções. Jean Rivero ${ }^{76}$, por exemplo, não enuncia essas diferenças de requisitos para configurar o dano ressarcível decorrente da adoção de condutas lícitas ou ilícitas praticadas pelo Estado. Para esse doutrinador estrangeiro, há necessidade de se demonstrar a certeza, a especialidade, a anormalidade e o alcance de uma situação juridicamente protegida para caracterizar o dano, independentemente de que o mesmo seja proveniente de uma conduta lícita ou ilícita.

Todavia, existem na doutrina outros posicionamentos que rechaçam a especialidade, a particularidade ou a singularidade do dano como pressupostos necessários para gerar a responsabilidade do Estado por danos causados por atos lícitos.

No Brasil, atacando de forma específica o critério da especialidade para caracterização do dano antijurídico, manifesta-se César Viterbo Matos Santolim ${ }^{77}$, in verbis: “Aceitar-se que o Estado somente tem a obrigação de indenizar naqueles casos onde o número de atingidos pelo ato legislativo é reduzido é trazer para o plano quantitativo uma situação que é de qualidade. A questão não é quem ou quantos o Estado alcança, mas como e por que o faz". E conclui o autor:

Ficando o Estado, independentemente de manifestar seu poder pela via executiva, legislativa ou judiciária, preso à responsabilidade objetiva por seus atos, que necessita, tão-somente, da demonstração do prejuízo antijurídico e do nexo de causalidade entre este e o ato estatal, o que deve ser examinado é se o interesse tutelado juridicamente e que serve de

\footnotetext{
75 BRUNINI, Weida Zancaner. Da responsabilidade extracontratual da Administração Pública. São Paulo: Revista dos Tribunais, 1981, pp. 55-56.

${ }^{76}$ RIVERO, Jean. Direito Administrativo. (Trad. de Rogério Ehrhardt Soares). Coimbra: Almedina, 1981, pp. $314-315$.

77 SANTOLIM, César Viterbo Matos. A responsabilidade civil do Estado por ato legislativo. Estudos Jurídicos, São Leopoldo (RS), n. 55, v. 22, pp. 44-54, 1989, p. 51.
} 
substrato ao ato, é mais ou menos relevante que aquele que decorre do dano havido ${ }^{78}$.

Segundo Santolim, o fundamento da responsabilidade do Estado por atos legislativos constitucionais - pode-se dizer atos lícitos, independentemente de serem atos legislativos - não deve referir-se ao parâmetro da igualdade perante os encargos públicos, e sim relacionar-se através de uma comparação entre o valor atribuído ao bem jurídico que é tutelado pelo ato legislativo com o valor do bem jurídico que esse mesmo ato violou. Seria através de uma análise comparativa de valores dos direitos afetados, então, que se permitiria a verificação da responsabilidade.

No direito estrangeiro, Miguel Marienhoff ${ }^{79}$ também repudia a especialidade como critério apto a verificar o direito à indenização. Sustenta que mesmo no caso de uma lei causadora de um prejuízo geral, ou seja, a um grande número de pessoas e não um prejuízo meramente particular, que resulte em oposição ou em violação de uma declaração, direito ou garantia constitucional, dita lei deve ser declarada inconstitucional ou deve-se admitir a responsabilidade do Estado pelo prejuízo ou dano que sua aplicação ocasiona no patrimônio dos administrados, ainda que não se trate de um indivíduo ou de um grupo de indivíduos.

Como exemplo, referido autor expõe a hipótese da perda definitiva da propriedade sobre uma coisa, que até então estava sob o domínio privado, através de uma disposição legislativa que a declara de domínio público, porém silencia quanto à indenização. Segundo seu entendimento, tal disposição não traduz, tecnicamente, uma carga pública, mas sim um despojo ou uma confiscação, o que de maneira alguma se harmoniza com disposições constitucionais que garantam o direito de propriedade.

Afirma o autor que a carga pública tem como traço típico o caráter transitório, posto que, se assim não fosse, a sociedade sob regime semelhante se converteria em escrava. Por isso, defende que a desigualdade nas cargas públicas não deva ser o único fundamento possível da responsabilidade do Estado, já que o respeito aos direitos

\footnotetext{
${ }^{78}$ SANTOLIM, César Viterbo Matos. A responsabilidade civil do Estado por ato legislativo. Estudos Jurídicos, São Leopoldo (RS), n. 55, v. 22, pp. 44-54, 1989, p. 53.

${ }^{79}$ MARIENHOFF, Miguel S. Responsabilidad del Estado por su actividad legislativa. Revista de Direito Público, São Paulo, n. 68, pp. 5-18, out./dez. 1983, passim.
} 
adquiridos ou o respeito ao direito de propriedade também consubstanciam razão para $\operatorname{tanto}^{80}$.

Das colocações e opiniões ofertadas acima, é possível extrair que o princípio da igualdade da repartição dos ônus das cargas públicas sustenta a necessidade da reparação, pelos seguintes argumentos a seguir sintetizados.

Em primeiro lugar, considera-se que não é totalmente dispensável a distinção entre ato ilícito e lícito, ainda que o ordenamento jurídico tenha acolhido uma forma de responsabilidade do Estado de moldes objetivos. A diferenciação revela-se importante, sobretudo porque repercute sobre a caracterização do dano antijurídico, facilitando a obtenção de indenização pelo particular quando provado que o ato é ilícito, já que, neste caso, não se requer a demonstração da especialidade e da anormalidade.

Inexistindo condescendência com a atitude, que é fulminada com a anulação, não há porque se aceitar os seus efeitos, especialmente quando afetam bens para os quais se criou e se destina o próprio ordenamento jurídico. Assim, se a conduta é estatal e ilícita, há que se fazer cessá-la e se é produzido um dano certo e não eventual, que atinge um interesse legítimo, por conta de tal conduta (nexo de causalidade), razão existe para se recompensar.

Por outro lado, se o ato é lícito, não há motivo para que este deixe de prevalecer. Entretanto, sua conservação pode implicar efeitos diversos para os particulares, de modo que é necessário ponderar qual seria o fundamento que embasaria o ressarcimento nesta hipótese, caracterizando, consequentemente, o dano que enseja a reparação.

Ainda, a idéia de que os ônus e encargos decorrentes da vida em sociedade devem ser repartidos de forma equânime entre os particulares faz com que, necessariamente, o requisito da especialidade esteja presente na caracterização do dano antijurídico. Uma breve incursão no conteúdo jurídico do princípio da igualdade faz-se necessária.

Das lições de Celso Antônio Bandeira de Mello sobre o princípio da igualdade, extrai-se que a lei pode escolher qualquer elemento residente nas coisas, pessoas ou situações para erigir como fator discriminatório, de modo que um ou outro dos direitos

${ }^{80}$ MARIENHOFF, Miguel S. Responsabilidad del Estado por su actividad legislativa. Revista de Direito Público, São Paulo, n. 68. pp. 5-18, out./dez. 1983, p.13. 
relacionados a tais bens jurídicos podem ser atingidos pela lei, posto que "não é no traço de diferenciação escolhido que se deve buscar algum desacato ao princípio isonômico". 81

E prossegue o autor:

As discriminações são recebidas como compatíveis com a cláusula igualitária apenas e tão-somente quando existe um vínculo de correlação lógica entre a peculiaridade diferencial acolhida por residente no objeto, e a desigualdade de tratamento em função dela conferida, desde que tal correlação não seja incompatível com interesses prestigiados na Constituição. (grifos do autor) ${ }^{82}$.

Analisando de modo específico de que forma um discrímen legal convive com a isonomia, o jurista pátrio ${ }^{83}$ estabelece a imprescindibilidade da concorrência de quatro elementos:

a. que a desequiparação não atinja de modo atual e absoluto, um só indivíduo;

b. que as situações ou pessoas desequiparadas pela regra de direito sejam efetivamente distintas entre si, vale dizer, possuam características, traços, nelas residentes, diferenciados;

c. que exista, em abstrato, uma correlação lógica entre os fatores diferenciais existentes e a distinção de regime jurídico em função deles estabelecida pela norma jurídica;

d. que, in concreto, o vínculo de correlação supra referido seja pertinente em função dos interesses constitucionalmente protegidos, isto é, resulte em diferenciação de tratamento jurídico fundada em razão valiosa, ao lume do texto constitucional, para o bem público.

Das considerações do autor em questão, observa-se que, de fato, quando a lei atinge de modo específico um só indivíduo, acrescente-se também um grupo de indivíduos, ferindo, portanto, o disposto na letra "a" acima, ou se trata de lei inconstitucional ou, sendo constitucional - porque, por um lado, há países que não realizam o controle judicial de constitucionalidade das leis e, por outro, tem-se que a própria atuação estatal, na maioria das vezes, produz uma discriminação, particulariza uma situação para realizar o interesse público - produz uma desigualdade, que deve ser minorada de outra forma (já que o ato

${ }^{81}$ MELLO, Celso Antônio Bandeira de. Conteúdo jurídico do princípio da igualdade. 3. ed. Malheiros: São Paulo, 2002, p. 17.

${ }^{82}$ Ibidem, p. 17.

${ }^{83}$ Ibidem, p. 41 . 
deve ser mantido), através de uma compensação econômica, de modo a manter a harmonia social almejada pelo ordenamento jurídico.

Por isso, o princípio da igualdade, que se traduz no correspondente dever de repartição equânime dos encargos públicos, enseja a pretensão reparatória quando o ato, dada a necessidade de satisfação do interesse público, deve ser mantido.

Cabe ressaltar que a imprescindibilidade da ocorrência dos elementos descritos nas letras "c" e "d" elencadas pelo citado autor revela a necessidade de proporcionalidade entre o fator de discrímen eleito e os parâmetros constitucionais, de modo que não se fere a igualdade através simplesmente de um critério quantitativo (o número de pessoas), mas também em razão da desconformidade com o ordenamento jurídico posto ${ }^{84}$. Aprecia-se, portanto, a razão valiosa da diferenciação estabelecida para a consecução do interesse público.

A teoria de Miguel Marienhoff, que dispensa o requisito da especialidade do dano antijurídico para configurar a responsabilidade civil estatal, baseia-se, contudo, em outro fundamento: o desrespeito a algum princípio ou postulado constitucional (como a propriedade e os direitos adquiridos). Ocorre que, se o ato estatal desrespeita o conteúdo da Constituição, logo se tem uma inconstitucionalidade material, de modo que isto o torna ilícito, inconstitucional. Não se poderia conceber uma lei que atinja a substância de um direito, sem a previsão do seu correspondente patrimonial como constitucional, posto que não é concedido ao Estado o poder de confiscar bens.

Há, então, subsídios suficientes para atendimento da pretensão de ressarcimento porque houve afronta a um direito constitucionalmente protegido, causando um dano que, para sua caracterização como antijurídico, não necessita dos requisitos da especialidade e da anormalidade, posto que decorre de um ato inconstitucional.

Se a princípio parece que pela sua teoria o autor ampliará o rol de possibilidades hábeis a ensejar a responsabilidade estatal, dispensando para a caracterização do dano o requisito da especialidade, por outro vislumbra-se na verdade que o fundamento utilizado

\footnotetext{
${ }^{84}$ Veja-se o exemplo elaborado por Fernando Facury Scaff, consistente na impossibilidade de se estabelecer, por meio de qualquer norma, regime jurídico diverso daquele das demais empresas privadas para as sociedades de economia mista e empresas públicas, em razão tanto do disposto no artigo $173, \S 1^{\circ}$ da $\mathrm{CF}$, bem como em razão do artigo $5^{\circ}$, caput da $\mathrm{CF}$, que estabelece que todos são iguais perante a lei, sem distinção de qualquer natureza. Cf. SCAFF, Fernando Facury. Responsabilidade civil do Estado intervencionista. 2. ed. Rio de Janeiro: Renovar, 2001, p. 191.
} 
para tanto reside numa hipótese de inconstitucionalidade material: ferir o direito de propriedade ou o direito adquirido.

Assim, entende-se necessário que o dano, no caso de atos lícitos, seja ainda, para além de sua qualificação de certeza e de afetação de uma situação juridicamente relevante, caracterizado pela especialidade e pela anormalidade, coadunando-se com o fundamento de que os prejuízos causados pelo Estado, independentemente de se tratar de ato administrativo, legislativo ou judicial, devem ser recompostos quando ferirem o princípio da igualdade perante os encargos públicos.

\subsection{RESPONSABILIDADE CIVIL DO ESTADO POR ATO LÍCITO E O DEVER DE INDENIZAR DECORRENTE DO SACRIFÍCIO DE DIREITO}

Considerando que para a ocorrência da responsabilidade deve haver um dano antijurídico, cabe analisar quando o comportamento estatal, mesmo que obediente a todas as condições exigidas pelo ordenamento jurídico, ou seja, mesmo sendo lícito, é apto a provocar um dano antijurídico que gera a responsabilidade.

Muito já se discutiu na doutrina, tanto pátria quanto estrangeira, sobre a responsabilidade civil do Estado por atos lícitos, sendo que suas condições de existência ainda estão longe de uma fixação definitiva, como observa Rui Stoco ${ }^{85}$ :

(...) nem a doutrina, nem a jurisprudência lograram estabelecer critérios precisos no que se refere à indenizabilidade em casos que tais (atos lícitos).

A casuística tem demonstrado que alguns comportamentos comissivos lícitos da Administração Pública têm sido considerados indenizáveis, enquanto que outros não, embora todos eles se subsumam na teoria em estudo.

Vale salientar que a doutrina estrangeira já considerou mesmo imprópria a consagração de uma responsabilidade estatal por atos lícitos, não significando, contudo, que os prejuízos gerados por tais atos devessem ficar a descoberto. Em relação a esse tipo de ato haveria, na verdade, dever de indenização, em razão da existência de um dano lícito, e não propriamente responsabilidade, que só ocorreria em relação aos atos ilícitos. É o

\footnotetext{
${ }^{85}$ STOCO, Rui. Tratado de Responsabilidade civil. 7. ed. São Paulo: Revista dos Tribunais, 2007, p. 1185.
} 
posicionamento, por exemplo, defendido por Renato Alessi ${ }^{86}$, para quem os atos lícitos ocasionariam lesão a direito, ou seja, uma debilitação do direito do particular, enquanto que em razão aos atos ilícitos ocorreria violação a direito. A distinção principal entre os institutos é que em relação ao primeiro, ato lícito, corresponderia o dever de indenizar, cujo conteúdo é limitado ao valor efetivo e atual do bem, objeto do direito sacrificado. Já na segunda hipótese, ato ilícito, caberia o ressarcimento, que compreende todos os casos derivados do fato. $\mathrm{O}$ ressarcir difere-se do indenizar, a ponto de esta diferença refletir-se nas quantias respectivas de quem foi violado ou lesionado em seu direito ${ }^{87}$.

Segundo Guido Zanobini, que também compartilha desse mesmo entendimento, não se trata propriamente de responsabilidade quando se está diante de ato lícito, posto que nessa hipótese ocorre uma conversão forçada de um direito individual num outro direito que representa o valor econômico ${ }^{88}$. Para Canotilho, cogita-se na hipótese de um conflito de interesses entre várias situações jurídicas, de modo que o ordenamento, ao mesmo tempo em que autoriza o sacrifício do direito de um sujeito para beneficiar outro, impõe, por razões de equidade, a obrigação de indenização a favor do titular do direito sacrificado $^{89}$.

No mesmo sentido da distinção entre indenização e responsabilidade tem-se a posição de Fernando Garrido Falla, na Espanha ${ }^{90}$.

Em suma, na opinião de tais juristas, a responsabilidade ficaria compreendida nas hipóteses decorrentes de atos ilícitos praticados pelo Estado, de modo que os danos provenientes de comportamentos lícitos não estariam albergados pelo instituto, mas sim pela categoria da indenização, o que acarretaria diferenças no valor a ser pago pelo Estado ao prejudicado.

\footnotetext{
${ }^{86}$ ALESSI, Renato. La responsabilitá della pubblica amministrazione, Vol. I. Milano: Dott A. Giufrée, 1939, p. 244. Apud FALDINI, Cristiana Corrêa Conde. Responsabilidade do Estado pela prática de atos lícitos. Dissertação (Mestrado em Direito) - Faculdade de Direito, Universidade de São Paulo, São Paulo, 2007, p. 59.

${ }^{87}$ Cf. BRUNINI, Weida Zancaner. Responsabilidade extracontratual da Administração Pública. São Paulo: RT, 1981, p. 38.

${ }^{88}$ ZANOBINI, Guido. Corso di diritto amministrativo, I. Milano, 1958, p. 270. Apud Canotilho, José Joaquim Gomes. O problema da responsabilidade do Estado por actos lícitos. Coimbra: Almedina, 1974, p. 234.

${ }^{89}$ CANOTILHO, José Joaquim Gomes. O problema da responsabilidade do Estado por actos lícitos. Coimbra: Almedina, 1974, p. 234.

${ }^{90}$ FALLA, Fernando Garrido. Tratado de Derecho Administrativo. 4. ed. Madrid: Instituto de Estudios Políticos, 1971, p. 244.
} 
Todavia, já defendeu-se em passagem anterior deste trabalho, com amparo na doutrina nacional que, mesmo no caso de comportamentos lícitos, poderia ocorrer um resultado ilícito, dado que essa consequência pode causar um desequilíbrio juridicamente identificado nos encargos a que estão sujeitos os particulares, infringindo, assim, o princípio da igualdade perante os encargos públicos. Diante disso, o ato, mesmo sendo lícito, pode gerar um dano antijurídico, razão pela qual, de modo geral, no direito brasileiro, a doutrina cogita do fenômeno da responsabilidade do Estado aplicado aos atos lícitos.

Maria Sylvia Zanella Di Pietro ${ }^{91}$, por exemplo, aduz que ao contrário do Direito Privado, em que a responsabilidade exige sempre um ato ilícito (contrário à lei), no Direito Administrativo ela pode decorrer de atos ou comportamentos que, embora lícitos, causem a pessoas determinadas ônus maior do que o imposto aos demais membros da coletividade.

Weida Zancaner Brunini ${ }^{92}$, criticando especificamente o pensamento de Alessi, entende que a responsabilidade do Estado abrange tanto os danos provenientes de atividades lícitas quanto os de atividades ilícitas, não havendo por que cindir e apartar de seu campo de abrangência os danos provenientes de atividades lícitas.

Edmir Netto de Araújo ${ }^{93}$ admite o amparo ao particular prejudicado por ato lícito imputável ao Estado (admite a responsabilidade objetiva), quando há sacrifício de direito patrimonial imposto compulsoriamente por este, para permitir a prevalência de um interesse público ou social relevante, atingindo unidades ou parcelas localizadas de particulares, sendo o dano conscientemente assumido pelo agente para esse fim.

No entanto, Celso Antônio Bandeira de Mello ${ }^{94}$, meditando sobre a questão colocada, mesmo admitindo a responsabilidade do Estado por ato lícito, observa que o pensamento de Alessi procede não no tocante à terminologia utilizada, mas na medida em que o autor italiano vislumbra duas hipóteses distintas: sacrifício de direito e responsabilidade, embora não as separe. Para o doutrinador pátrio, essa distinção é importante e deve ser feita porque não se confundem as situações em que a lei autoriza um

\footnotetext{
${ }^{91}$ DI PIETRO, Maria Sylvia Zanella. Direito Administrativo. 22. ed. São Paulo: Atlas, 2009, p. 638.

92 BRUNINI, Weida Zancaner. Responsabilidade extracontratual da Administração Pública. São Paulo: RT, 1981, pp. 39-40.

93 ARAÚJO, Edmir Netto de. Curso de Direito Administrativo. 4. ed. São Paulo: Saraiva, 2009, p. 764.

${ }^{94}$ MELLO, Celso Antônio Bandeira de. Curso de Direito Administrativo. 26. ed. São Paulo: Malheiros, 2009, p. 985.
} 
comportamento cuja finalidade não é outra senão sacrificar o direito, daquelas outras situações em que se atinge de forma reflexa o direito de alguém por um comportamento estatal que visava satisfazer outro interesse jurídico (ato lícito que gera responsabilidade).

Bandeira de Mello registra que nos casos em que o Direito confere ao Estado o poder jurídico diretamente preordenado ao sacrifício do direito de outrem não se está no campo da responsabilidade. Exemplo dessa situação seria o caso da desapropriação, onde o Estado está, especificamente no Brasil, obrigado a indenizar previamente pelo ato de despojamento compulsório da propriedade. Diversamente, quando uma atividade lícita do Estado, orientada para certo fim não necessariamente colidente com o direito de outrem, vem a compor situação na qual este último resulta transgredido, tem-se a hipótese que faz atuar a responsabilidade estatal ${ }^{95}$.

Lançando mão da Teoria Geral do Direito, em que a responsabilidade melhor se situa, pode-se vislumbrar que as hipóteses de indenização por sacrifícios de direito e responsabilidade decorrente de atos lícitos diferem entre si. Kelsen ${ }^{96}$ distingue as situações ao elucidar que nem sempre o dever jurídico de um indivíduo em ressarcir os prejuízos materiais ou morais causados por ele ou por outrem consiste numa sanção. A ordem jurídica pode impor aos indivíduos o dever de não causarem prejuízos a outrem, sem estatuir, contudo, a obrigação ou o dever de indenizar os prejuízos causados em razão da infração dessa regra. Tal seria o caso se os indivíduos não pudessem evitar a sanção através da indenização do prejuízo. Porém, segundo o Direito positivo, pode-se, normalmente, evitar a sanção pela indenização do prejuízo. Nas palavras do autor:

Ele não só é obrigado a não causar a outrem qualquer prejuízo com a sua conduta mas ainda, no caso de, com essa conduta, ter causado um prejuízo a outrem, a indenizar esse prejuízo. A sanção da execução civil constitui dois deveres: o dever de não causar prejuízos, como dever principal, e o dever de ressarcir os prejuízos licitamente causados, como dever subsidiário que vem tomar o lugar do dever principal violado. $\mathrm{O}$ dever de ressarcir os prejuízos não é uma sanção, mas é esse dever subsidiário ${ }^{97}$.

Para explicar como se constitui a sanção, prossegue o autor:

A sanção da execução, isto é, a indenização compulsória do prejuízo através do órgão aplicador do Direito, apenas surge quando este dever

\footnotetext{
${ }^{95}$ MELLO, Celso Antônio Bandeira de. Curso de Direito Administrativo. 26. ed. São Paulo: Malheiros, 2009 , p. 985.

${ }^{96}$ KELSEN, Hans. Teoria pura do direito. Trad. João Baptista Machado. 6. ed. São Paulo: Martins Fontes, 1998, p. 139.

${ }^{97}$ Ibidem, p. 139
} 
não é cumprido. Se esta sanção da execução civil se dirige ao patrimônio do indivíduo que causou o prejuízo através de sua conduta e o não indenizou, este indivíduo responde por seu próprio delito, que consiste no não ressarcimento do prejuízo por ele causado. Mas, por este delito, isto é, pelo não-ressarcimento do prejuízo por ele causado, também pode responder um outro indivíduo ${ }^{98}$. (grifo nosso)

Pelo que se observa das lições de Kelsen, a imposição do dever de indenizar não pressupõe um ilícito, posto que se constitui num dever subsidiário (obrigação) e não numa sanção. Não há, nesse caso, ilicitude. Há um dano licitamente causado - que a ordem jurídica considerou, entende-se, passível de ocorrer - e que requer, todavia, o cumprimento de uma obrigação subsidiária. Daí diferenciar-se da responsabilidade, que pressupõe a ilicitude, uma vez que essa integra a sua própria concepção.

Em virtude dessas lições, assente que a ordem jurídica pode autorizar, ou mesmo determinar, de modo específico, que o Estado afete algum direito do particular, podendo até extingui-lo, e que, nesses casos, tem-se um dano licitamente produzido, na medida em que há previsão de cumprimento de uma obrigação subsidiária consistente no pagamento do equivalente patrimonial do direito ${ }^{99}$. Há, enfim, uma conversão do direito no seu equivalente patrimonial.

Como fundamento para autorizar o Estado a sacrificar um direito, invoca-se, geralmente, a idéia de supremacia de algum interesse coletivo em face de situações jurídicas individuais, tal como legitimamente ocorre com o direito de propriedade nos casos de desapropriação, servidão e tombamento ${ }^{100}$. Dada a necessidade da satisfação de

98 KELSEN, Hans. Teoria pura do direito. Trad. João Baptista Machado. 6. ed. São Paulo: Martins Fontes, 1998 , p. 139.

${ }^{99}$ Reconhecendo essa possibilidade do Estado sacrificar os direitos causando danos lícitos aos particulares, observa Celso Antônio Bandeira de Mello que tal decorre da autorização conferida pela ordem jurídica ao Estado de “(...) especificamente em aniquilar o direito alheio, que se converterá em correlativa expressão patrimonial”. MELLO, Celso Antonio Bandeira de. Curso de Direito Administrativo. 26. ed. São Paulo: Malheiros, 2009, p. 985.

${ }^{100}$ PIRES, Luis Manoel Fonseca. A propriedade privada em área de proteção ambiental: limitações ou restrições administrativas. In: PIRES, Luis Manoel Fonseca. ZOCKUN, Maurício (coord.). Intervenções do Estado. São Paulo: Quartier Latin, 2008, p. 37. Não se trata, contudo, de posição compartilhada por todos os autores. Clóvis Beznos, por exemplo, defende que a desapropriação funda-se no próprio perfil do direito de propriedade tal como consagrado constitucionalmente, cujo contorno é composto da possibilidade de seu exaurimento, ou seja, o direito de propriedade, tal como concebe a Constituição, já traria ínsita a possibilidade de sacrifício. Cf. BEZNOS, Clóvis. Aspectos jurídicos da indenização na desapropriação. Tese (Doutorado em Direito). Faculdade de Direito - Pontifícia Universidade Católica de São Paulo, São Paulo, 2002, pp. 30-31. 
um determinado interesse público ${ }^{101}$, a Constituição autoriza o Estado a legitimamente investir contra um direito privado, aniquilando-o.

Comumente as hipóteses de sacrifícios de direitos são estudadas no setor da atividade estatal compreendido sob a rubrica de poder de polícia, expressão que recebe atualmente críticas da doutrina tanto em razão do fato de evocar uma época pretérita conhecida como Estado de Polícia, que precedeu o Estado de Direito, quanto em função deste designativo entonar uma carga autoritária, como se fosse inerente ao Estado o referido poder, sem a conotação de sua instrumentalidade. O poder de polícia, em seu sentido amplo, abrange tanto as leis quanto os atos administrativos destinados a impor limitações à liberdade e à propriedade dos indivíduos, de modo a entrelaçá-los ao interesse coletivo $^{102} \mathrm{e}$, em sentido restrito, limita-se às intervenções do Poder Executivo, quer gerais e abstratas como os regulamentos, quer concretas e específicas tais como as autorizações, as licenças, as injunções do Poder Executivo, destinadas a prevenir e obstar o desenvolvimento de atividades particulares contrastantes com os interesses sociais ${ }^{103}$.

No exercício do poder de polícia, o Estado goza da prerrogativa jurídica para legitimamente investir contra o direito do particular, podendo desde simplesmente imporlhe certas limitações que configurariam o próprio delineamento do direito, ao que, adotando-se a denominação e classificação de Carlos Ari Sundfeld ${ }^{104}$, que parece bastante didática, se denomina de condicionamentos de direitos, bem como pode impor sacrifícios de direitos, que corresponderiam a uma diminuição, suspensão ou eliminação das possibilidades de desfrute genericamente admitidas pelo ordenamento ao direito de

\footnotetext{
${ }^{101}$ Pode-se dizer que hoje não existe um único interesse público, mas vários interesses públicos que estão a exigir a sua realização por parte do Estado, dada a desvinculação da noção de interesse público com interesse da maioria, bem como diante da impossibilidade de identificação de uma maioria, com características homogêneas. Cf. JUSTEN FILHO, Marçal. Conceito de interesse público e a "personalização" do direito administrativo. Revista Trimestral de Direito Público, São Paulo, n. 26, pp. 115-136, 1999, pp. 115-136.

${ }^{102}$ Carlos Ari Sundfeld, em estudo promovido sobre o tema e, adotando em substituição ao designativo poder de polícia a expressão administração ordenadora, aponta que essa função estatal abrange, atualmente, mais do que a simples imposição de um não fazer. Segundo o autor, o Estado, no exercício do seu poder de autoridade, tendo em vista a necessidade de organização da vida privada para promoção do bem comum pode tanto: a) dar origem a direitos; b) regular o exercício dos direitos titularizados pelos particulares, de modo a definir-lhes o perfil; c) sacrificá-los sendo que, neste último caso, os sacrifícios atingem apenas os direitos patrimoniais, de modo parcial ou total e d) pode impor prestações dos particulares em favor da Administração. Cf. SUNDFELD, Carlos Ari. Direito Administrativo Ordenador. São Paulo: Malheiros, 2003, pp. 26-27.

${ }^{103}$ MELLO, Celso Antonio Bandeira de. Curso de Direito Administrativo. 26. ed. São Paulo: Malheiros, 2009 , p. 815.

${ }^{104}$ SUNDFELD, Carlos Ari. Op.cit., p. 86.
} 
propriedade $^{105}$. Os primeiros não gerariam direito à indenização, haja vista tratar-se de uma forma de compatibilização entre o interesse público e o privado, não infligindo mais que um gravame normal ao direito, inerente à convivência em sociedade, enquanto que os segundos acarretariam o direito à indenização, por inviabilizarem o próprio direito.

Vale considerar aqui que os ordenamentos jurídicos estrangeiros há muito já se preocuparam em distinguir dentre os atos estatais que incidem sobre a propriedade aqueles que geram direito à indenização daqueles outros que se tratam de medidas que, embora restritivas, constituem-se no campo de delineamento do próprio direito. No direito norteamericano, relata García de Enterría ${ }^{106}$ a existência da distinção entre taking ou expropriação e regulation, que é legítima e embora possa resultar na redução de alguma utilidade ao proprietário de qualquer bem, não segue acompanhada de indenização alguma. Conforme ensina o doutrinador espanhol, com base nas lições de Schwartz, o critério estabelecido para determinar quando termina uma regulation e começa um taking pode ser auferido, de modo geral, quando o Estado, através de seu poder expropriatório (eminent domain), toma a propriedade e a destina a um uso que beneficia o público, enquanto que o poder de polícia (fonte normal da regulation) implica simplesmente na restrição do uso ou do desfrute que o proprietário tem sobre sua propriedade, já que um exercício ilimitado dos direitos de propriedade é considerado contrário ao interesse público.

Há que se salientar que Carlos Ari Sundfeld refere-se explicitamente ao direito de propriedade quando trata das hipóteses de sacrifícios de direito, desenvolvendo o estudo do regime jurídico dos sacrifícios somente em relação a esse direito, uma vez que compreende que os demais direitos não admitem tal vulneração estatal, sob pena de inconstitucionalidade - com exceção das hipóteses de supressão a título de sanção previstas na própria Constituição e na lei, tais como a prisão pela prática de crimes, bem como nas situações de estado de defesa e estado de sítio -, mas apenas uma interferência

\footnotetext{
105 Não há unanimidade nem entre os autores, nem nos tribunais a respeito da classificação das intervenções do Estado na liberdade e na propriedade alheia. Para Maria Sylvia Zanella Di Pietro, por exemplo, haveria diversas modalidades em que o Estado poderia restringir o direito de propriedade, cada qual o afetando de modo diverso: as limitações administrativas, a ocupação temporária e a requisição de imóveis, o tombamento, a servidão administrativa, a desapropriação, a requisição de bens móveis e fungíveis, a edificação e o parcelamento compulsório. DI PIETRO, Maria Sylvia Zanella. Direito Administrativo. 22. ed. São Paulo: Atlas, 2009, pp. 124-125. Edmir Netto de Araújo classifica as restrições à propriedade privada em limitações administrativas, requisição de imóveis (no qual inclui a ocupação temporária), tombamento, servidão administrativa, desapropriação e parcelamento ou edificação compulsórios. ARAÚJO, Edmir Netto de. Curso de Direito Administrativo. 4. ed. São Paulo: Saraiva, 2009, pp. 1028-1029.

${ }^{106}$ ENTERRÍA, Eduardo García de. La responsabilidad patrimonial del Estado Legislador en el Derecho español. 2. ed. Navarra: Civitas, 2007, p. 155.
} 
estatal no âmbito do lícito, ou seja, da determinação das condições em que devem ser adquiridos e exercidos pelos indivíduos ${ }^{107}$.

Considerando compreender-se, hodiernamente, que o conteúdo do direito de propriedade refere-se à forma mais ampla possível da concepção de propriedade, ou seja, inclui todo e qualquer direito patrimonial assegurado ao cidadão, não se limitando à propriedade imóvel, mas sim, como dispõe o Decreto-lei no 3.365, de 1941, em seu artigo $2^{\circ}$, abarca todos os bens, sejam eles corpóreos ou incorpóreos, reais ou pessoais, excluindose apenas aqueles personalíssimos, parece acertado tratar do sacrifício de direito sempre relacionado ao direito de propriedade, ou melhor, tem-se que somente se pode admitir a existência um sacrifício de algum direito subjetivo patrimonial do particular, o qual está abrangido na garantia constitucional da propriedade.

Atualmente o significado do direito de propriedade acolhe, para além da propriedade sobre bem imóvel, qualquer direito ao crédito e outros bens, a possibilidade de apropriar-se de ações, o direito de autor, etc. ${ }^{108}$. Esse caráter amplo do conceito do referido direito, que implicará diferentes possibilidades atribuídas ao beneficiário, a depender do bem sobre o qual recaia a garantia (um terreno ou um bem móvel de consumo, por exemplo), permitirá considerar que as ablações praticadas pelo Estado de forma legítima estarão vinculadas a algum direito de índole patrimonial, dado o fato de que é o direito subjetivo patrimonial que permitirá ao homem talhar para si um espaço, maior ou menor, de liberdade ${ }^{109}$.

Compreendendo-se, então, que um sacrifício de direito atua sobre o direito de propriedade, há que se ressaltar que nessas hipóteses tem-se consagrada a possibilidade legítima de gerar um dano ao direito do particular, posto que, com base na defesa de um interesse da coletividade, haveria uma prerrogativa conferida ao Estado de, nos estritos limites da necessidade, aniquilar ou amesquinhar o direito alheio, ao que não corresponde,

\footnotetext{
${ }^{107}$ SUNDFELD, Carlos Ari. Direito Administrativo Ordenador. São Paulo: Malheiros, 2003, p. 86.

${ }^{108}$ Sobre a necessidade de compreender-se o direito de propriedade como abrangente de todos os direitos subjetivos privados de natureza patrimonial, tem-se que tal é uma decorrência da transformação econômica da sociedade. Como justifica Rui Medeiros, a necessidade de alargar o conceito constitucional de propriedade privada aos direitos subjetivos privados de natureza patrimonial só se torna verdadeiramente visível no momento em que o Estado, despido de sua veste liberal, multiplica as intervenções na esfera jurídica dos particulares. Como informa o autor, a opinião de que o conceito constitucional de propriedade abrange direitos patrimoniais privados é, hoje, geralmente defendida no Direito Comparado, no âmbito da Convenção Européia dos Direitos do Homem e pela doutrina portuguesa. Cf. MEDEIROS, Rui. Ensaio sobre a responsabilidade civil do Estado por actos legislativos. Coimbra: Almedina, 1992, pp. 251-252.

${ }^{109}$ Ibidem, p. 266.
} 
contudo, a imunidade estatal ao dever de recompor o patrimônio alheio de forma subsidiária. Haveria um direito à indenização nessas situações de sacrifícios de direitos, por ser este um dos meios de defesa e proteção dos cidadãos previstos em qualquer sistema democrático, como o adotado pela Constituição Federal de 1988.

A indenização como obrigação subsidiária seria o símbolo do respeito pelo poder aos direitos individuais, traduzindo-se também em evidente significado do princípio da igualdade, na medida em que proporciona uma repartição equânime decorrente de um ônus necessário para a realização do bem comum, representaria também respeito aos postulados de segurança jurídica e preservação da harmonia do ordenamento. Não se poderia admitir que a ordem jurídica de um Estado que acolhe o princípio da igualdade como inviolável, ao que se percebe do que ocorre no direito brasileiro em face do que dispõe o artigo $5^{\circ}$, caput c.c. artigo $60, \S 4^{\circ}$, inciso IV da $\mathrm{CF} / 88$, possibilitasse que o Estado adotasse uma conduta destinada ao aniquilamento do direito de um particular ou de um grupo deles, causando assim um prejuízo especial e anormal, ou seja, exigindo mais de uns do que de outros, sem prever o pagamento do equivalente valor patrimonial desse direito. Mais do que mera possibilidade, a indenização traduzir-se ia num dever jurídico imposto pela norma jurídica superior, que consagra e estabelece garantias aos direitos individuais, elegendo-os como invioláveis.

O direito previsto constitucionalmente seria amesquinhado se fosse autorizado ao Estado agredi-lo, quando um interesse jurídico mais relevante devesse prevalecer, mas não se obrigasse esse mesmo Estado a convertê-lo no equivalente patrimonial. Esse dever jurídico de indenização é assim, em última instância, uma necessidade de resguardo da própria ordem jurídica e dos direitos e garantias que ela prevê, decorrência lógica, portanto, do Estado de Direito.

É o que ocorre com o direito de propriedade nos casos de desapropriação, hipótese clara em que a indenização funciona como equivalente patrimonial do direito. Clóvis Beznos $^{110}$, em trabalho no qual analisou o dever de indenização para os casos de vulneração do direito de propriedade em virtude de desapropriação, salienta que nas situações de desapropriação indireta, ou seja, quando ocorre o despojamento da propriedade privada pela Administração, com ânimo definitivo, sem os pressupostos

\footnotetext{
${ }^{110}$ BEZNOS, Clóvis. Aspectos jurídicos da indenização na desapropriação. Tese (Doutorado em Direito). Faculdade de Direito - Pontifícia Universidade Católica de São Paulo, São Paulo, 2002, p. 50 et. seq.
} 
exigíveis para tanto (sem prévia e justa indenização e adoção do processo devido), constitui-se um ato ilícito e vulnera-se, de pronto, tanto o direito de propriedade e o procedimento prescrito na Constituição para efetivação da desapropriação, como também resta atingido o princípio constitucional da igualdade, de vez que alguém se vê especialmente sacrificado pela ação administrativa, sem nenhuma compensação ${ }^{111}$.

Infere-se, com isso, que o ato estatal cuja finalidade é realizar o sacrifício do direito em nome do bem comum deve prever o seu equivalente patrimonial, ou seja, o ato estatal deve dizer de antemão que a consequência do esgarçamento do direito ensejará indenização, de modo a não produzir uma violação da ordem jurídica.

Ademais, observa-se, ainda, que no ordenamento jurídico brasileiro basta apenas um uso danoso da propriedade pelo Estado para que seja cabível a indenização (artigo $5^{\circ}$, inciso XXV da CF), de modo que mais razão haverá para que seja devida a indenização quando de forma mais contundente o Estado viole uma acepção protegida pela garantia constitucional da propriedade $^{112}$.

Subsiste, no entanto, o problema prático de saber quais, efetivamente, dentre as medidas estatais constituem-se em sacrifícios e quais representam delimitações do direito, dado que não há consenso, na doutrina e na jurisprudência, na classificação de quais formas de intervenção do Estado no direito alheio se constituem em sacrifícios de direito. E a distinção é de capital importância, pois as primeiras obrigariam o Estado a prever o equivalente patrimonial do direito, enquanto que as segundas seriam mera conformação jurídica do direito, que não ensejariam o pagamento da indenização.

\subsubsection{Sacrifício de direito}

Vários critérios são utilizados para a caracterização do sacrifício do direito. Destacam-se os seguintes ${ }^{113}$ : a) a idéia de que haverá sacrifício quando ocorrer

\footnotetext{
${ }^{111}$ Defendendo que a desapropriação comina um dano lícito, fazendo nascer o dever de o Estado recompor o conteúdo econômico do direito sacrificado antes de esse instituto deflagrar os seus efeitos jurídicos ver também a posição de ZOCKUN, Maurício. A matriz constitucional da responsabilidade do Estado, a responsabilidade do Estado por atos legislativos e a obrigatoriedade de prévia indenização. Tese (Doutorado em Direito). Faculdade de Direito - Pontifícia Universidade Católica de São Paulo, São Paulo, 2009, p. 117.

${ }^{112}$ MOTA, Maurício Jorge Pereira da. Responsabilidade civil do Estado legislador. Rio de Janeiro: Lumen Juris, 1999, p. 199.

${ }^{113}$ SUNDFELD, Carlos Ari. Direito Administrativo Ordenador. São Paulo: Malheiros, 2003, pp. 87-95.
} 
transferência do bem para a propriedade do Estado; b) a análise do tipo de ato veiculador do gravame (tratando-se de ato administrativo seria hipótese de sacrifício; em sendo imposto através de uma lei, seria um condicionamento do direito); c) um juízo acerca da generalidade ou singularidade da medida; d) o crivo sobre a forma de afetação do direito, ou seja, em que medida o ato estatal afeta o conteúdo do direito, restringindo a preservação desse conteúdo mínimo ${ }^{114}$.

Inicia-se a análise pelo critério relativo ao veículo que impõe o condicionamento: a noção de que, simplesmente, por se tratar de ato legislativo, esse realizaria um condicionamento de direito, enquanto que a restrição veiculada por ato administrativo constituiria sacrifício.

Tal compreensão, ao que se entende, parte do pressuposto de que a lei, por ser ato geral e abstrato, não pode mais do que estabelecer o regramento, o condicionamento dos direitos de todos os cidadãos. Essa conclusão, contudo, desconsidera que se vive hoje numa época em que se concebe como legítima a lei-medida, que visa à solução de uma situação concreta e específica. Como se verá detalhadamente no capítulo 1 da segunda parte deste trabalho, a lei atual pode veicular medidas específicas, destinadas a atingir determinadas situações, provocando consequências que não são gerais e sim especiais. Pode também, ainda que geral e abstrata, concretizar-se (ser aplicada) de forma específica, enquadrando determinado grupo de indivíduos. Nesse sentido, não se poderia simplesmente afirmar, sem analisar o conteúdo da formulação, que por se tratar de um ato legislativo este apenas veicularia restrições de caráter geral e abstrato que se configurariam como delineamentos do direito, pois esta é um concepção de lei vigente no Estado Liberal, que não mais se adequa hodiernamente.

A lei hoje pode vincular limitações à propriedade dos indivíduos que culminam com o esvaziamento do conteúdo do direito. Admite-se, como destaca Eduardo García de Enterría e Tomás-Ramón Fernández, a existência de leis materialmente expropriatórias, que excluem ou simplesmente diminuem as garantias comuns da propriedade. Poderia

\footnotetext{
${ }^{114}$ Eduardo García de Enterría também elenca o critério da singularidade da privação e do conteúdo essencial do direito de propriedade, como adotado pelo Tribunal Constitucional espanhol para verificar quando uma intervenção legislativa sobre uma classe determinada de propriedade deva qualificar-se como limitação ou como expropriação, embora o autor considere como critério substancial apenas o segundo. ENTERRÍA, Eduardo García de. La responsabilidad patrimonial del Estado Legislador en el Derecho español. 2. ed. Navarra: Civitas, 2007, p. 188 et. seq.
} 
ocorrer, inclusive, que uma lei especial disponha sobre a apropriação do bem e não tenha previsto ou exclua de maneira expressa a indenização ${ }^{115}$.

Como também escreve Agustín Gordillo, existem hoje leis de polícia, ou seja, a atividade de polícia, que hoje não mais se caracteriza como somente proibitiva, deixou de ser uma ação exercida somente através da função executiva, passando a se concretizar também através da faculdade de ditar normas que regem uma determinada atividade ${ }^{116}$.

Logo, existindo leis que podem veicular restrições cujo conteúdo pode chegar a aniquilar um direito, o juízo acerca do tipo de ato veiculador do condicionamento não é critério apto a realizar a diferenciação das situações em que se justifica o pagamento da indenização das quais tal não é cabível, sob pena de cometimento de flagrantes injustiças e, sobretudo, inconstitucionalidades.

Já quanto à alusão à característica da especialidade como apta a distinguir um sacrifício de um condicionamento do direito, tem-se que este seria um dos requisitos que deveriam ser levados em conta para permitir a diferenciação entre eles, não devendo ser considerado, contudo, como critério único. Isso porque, ao falar-se na especialidade, existe uma vasta gama de situações que vão desde a afetação de um único indivíduo até o alcance de todo um bairro ou uma comunidade, que podem ser considerados como atingidos de forma especial em comparação com o resto de toda a sociedade, ou seja, não há um critério jurídico unívoco que permita auferir quando ocorre uma afetação especial e quando ela se dá de modo generalizado pela sociedade.

Por certo, como aponta Carlos Ari Sundfeld, a adoção do requisito da especialidade quer evitar que ocorra a discriminação entre as pessoas, sem exigir-se mais de uma que de outras, entrelaçando-se, necessariamente, ao princípio da igualdade ${ }^{117}$.

Daí que o critério não poderia ser desconsiderado, posto compreender-se que se a restrição de um determinado direito difunde-se por toda a sociedade, logo ou houve a modificação do delineamento daquele direito ou trata-se não mais de um sacrifício

\footnotetext{
${ }^{115}$ ENTERRÍA, Eduardo García de. FERNÁNDEZ, Tomáz-Ramón. Curso de Derecho Administrativo. vol. II. 9. ed. Madri: Civitas, 2004, pp. 215-217.

${ }^{116}$ GORDILlO, Agustín. Tratado de Derecho Administrativo. Tomo 2. 5. ed. Belo Horizonte: Del Rey, 2003, pp. V-14.

${ }^{117}$ SUNDFELD, Carlos Ari. Direito Administrativo Ordenador. São Paulo: Malheiros, 2003, p. 91.
} 
legitimamente admitido pela Constituição, mas sim de uma total afronta a esta, ao subverter-se através dos atos infraconstitucionais os direitos que ela consagra.

É certo, porém, que não bastará a verificação da extensão numérica para se configurar o sacrifício, mas haverá que se considerar a forma de afetação do direito, ou seja, como ele é atingido em sua substância. Assim, a aferição da ocorrência de um sacrifício estaria relacionada, para além de uma especialidade de um prejuízo, à manutenção ou não de um conteúdo essencial mínimo do direito fundamental, isto é, o sacrifício se configuraria na medida em que esse conteúdo essencial do direito não tivesse sido respeitado, o qual só poderia ser legítimo se previsse a correspondente indenização, de modo proporcional ao sacrifício realizado. A impossibilidade de fruição do direito, tal como ocorre num tombamento que, por impingir medidas severamente restritivas, conduzissem à inviabilidade do uso que se faz da propriedade imóvel, seria caracterizada como sacrifício, embora o ato estatal não provocasse a transferência da titularidade do domínio acerca do bem.

Para caracterizar-se o sacrifício, haveria de levar-se em conta o conteúdo essencial do direito, ou seja, que prerrogativas esse direito oferece para o particular, no que consiste, qual a sua configuração no direito atual. O direito de edificação, por exemplo, seria uma faculdade que se atrelaria à essência do direito de propriedade, visto que, por certo, na possibilidade de uso, gozo e disponibilidade da coisa também se compreende a faculdade de transformá-la, edificá-la. Sua extinção implicaria eventual direito à indenização, independentemente do tipo de ato que a veiculasse.

Esse mesmo critério é utilizado por Eduardo García de Enterría, bem como pelo Tribunal Constitucional espanhol, para verificar quando ocorre uma intervenção legislativa que possa ser qualificada como uma expropriação forçada e não como uma mera delimitação do conteúdo do direito. Segundo o autor, a não preservação de um conteúdo essencial do direito de propriedade por parte da lei deve ser articulada como uma lei expropriatória e, por isso, resulta a necessidade de que ocorra a indenização correspondente $^{118}$.

Acerca de como se caracterizaria o conteúdo essencial de um direito, é Celso Antônio Bandeira de Mello quem nos traz algum parâmetro para aferição. O autor dispõe

118 ENTERRÍA, Eduardo García de. La responsabilidad patrimonial del Estado Legislador en el Derecho español. 2. ed. Navarra: Civitas, 2007, p. 192. 
que o conteúdo essencial do direito estaria relacionado à funcionalidade do bem, ou seja, o direito estaria sacrificado quando não se pudesse dar ao bem utilização funcional, entendendo-se por funcionalidade a aptidão natural deste em conjugação com a destinação social que cumpre, segundo o contexto em que esteja inserido ${ }^{119}$. De acordo com a vocação jurídica do direito, sua configuração constitucional e, ainda, avaliado segundo as circunstâncias históricas de um determinado momento, é que se poderia analisar se o ato estatal legitimamente praticado constituiria mero delineamento deste ou se haveria uma supressão do direito ou de seu conteúdo ${ }^{120}$.

Em resumo, pode-se dizer que o sacrifício de um direito, ou seja, o seu legítimo esgarçamento, total ou parcial, devidamente justificado e embebido de razoabilidade, restaria configurado através da supressão do seu conteúdo essencial, auferido conforme o seu delineamento jurídico e a acepção, a funcionalidade que a ele se atribui num determinado momento histórico. A conversão de tal direito no seu equivalente patrimonial seria mais do que uma forma de precaução, configuraria um dever, um requisito essencial cujo descumprimento levaria à sua invalidade.

Vale observar, ainda, que se é em razão do aniquilamento do conteúdo de um direito que é devida a indenização, logo se pode também compreender que não é a sua aquisição por parte do Estado que gera o direito à indenização. Como aduz Carlos Ari Sundfeld $^{121}$, não haveria justificativa jurídica razoável para diferenciar duas hipóteses em que o ato estatal destina-se à violação do patrimônio - uma na qual ocorre a aquisição da propriedade pelo Estado e na outra não - de modo a possibilitar a atribuição de regimes jurídicos diferenciados. Seria a supressão do direito, de seu conteúdo mínimo, que exigiria a conversão deste no equivalente patrimonial e não estaria, necessariamente, vinculado à idéia de aquisição deste pelo Estado.

\footnotetext{
${ }^{119}$ MELLO, Celso Antônio Bandeira de. Natureza jurídica do zoneamento - Efeitos. Revista de Direito Público. Revista dos Tribunais, São Paulo, v. 61, pp. 34-47, 1982, pp. 39-40.

${ }^{120}$ Sobre as variadas formas de se verificar a funcionalidade de um bem, confira-se, a título de exemplo, a decisão monocrática proferida pelo Ministro Joaquim Barbosa do Supremo Tribunal Federal, por ocasião do julgamento do Recurso Extraordinário no 361.127 , na qual o Ministro fez expressa observação de que os proprietários de um bem imóvel que está situado na Avenida Paulista podem, de inúmeras formas, fazer uso lucrativo de tal imóvel, não se limitando simplesmente na possibilidade de venda do bem. STF, RE 361.127, Relator: Ministro Joaquim Barbosa, julgado em 22/09/2009, publicado em 09/10/2009. Disponível em: <http://www.stf.jus.br/portal/jurisprudencia/listarJurisprudencia.asp?s1=((361127.NUME.OU361127.DMS.) NAO S.PRES.\&base=baseMonocraticas $>$. Acesso em: 10 out. 2009.

${ }^{121}$ SUNDFELD, Carlos Ari. Direito Administrativo Ordenador. São Paulo: Malheiros, 2003, p. 89.
} 
A corroborar também tal posicionamento, confira-se a argumentação de Júlio César dos Santos Esteves ${ }^{122}$ :

As determinações constitucionais de indenização da propriedade não se esgotam, pois, nas previsões explícitas da ação expropriatória (art. $5^{\circ}$, XXIV) e da requisição com dano (art. $5^{\circ}, \mathrm{XXV}$ ). A redação, in concretu e particularizada do direito de propriedade inspira a necessidade de indenização, mesmo não se tratando de medida que envolva a transferência da propriedade para o domínio público ou sua utilização direta pelo Estado. ${ }^{123}$

Pelo variado conteúdo que assume o direito de propriedade não se poderia considerar que apenas nas hipóteses de transferência do domínio se teria direito à indenização, já que tal implicaria admitir o aniquilamento do direito por via transversa, o que estaria, por certo, em desacordo com o sistema constitucional pátrio.

Feitas essas considerações à respeito do delineamento do sacrifício do direito, é possível observar que a hipótese difere daquela em que atua a responsabilidade civil do Estado, posto que na primeira não há conexão com a produção antijurídica de um dano. A responsabilidade, por ter natureza também sancionatória, não se confunde com a obrigação subsidiária de pagamento de indenização, mas pode surgir quando houver descumprimento $\operatorname{desta}^{124}$.

O descumprimento do dever subsidiário, ou seja, a ausência do pagamento da indenização como estatuído pela norma constitucional, é que desencadeará a sanção da responsabilidade civil estatal, mas não há que se confundir os institutos, dado que no primeiro não houve uma violação da ordem jurídica, enquanto que no segundo, essa necessariamente ocorreu.

Mais duas particularidades, no entanto, devem ser consideradas neste ponto do trabalho, posto se referirem ao sacrifício do direito e, especificamente, relacionarem-se ao direito de propriedade tal como configurado no direito brasileiro. A primeira diz respeito ao fato de que, no ordenamento pátrio, o sacrifício do direito de propriedade exige para mais do que o pagamento do seu equivalente patrimonial, que este seja feito previamente, ou seja, antes da efetivação do ato, e de forma justa - mas a justiça já é circunstância

${ }^{122}$ ESTEVES, Júlio César dos Santos. Responsabilidade civil do Estado por ato legislativo. Belo Horizonte: Del Rey, 2003, p. 242.

${ }^{123}$ Ibidem, p. 242.

${ }^{124}$ Eis o posicionamento defendido por Fernando Dias Menezes de Almeida, com o qual se concorda. Cf. ALMEIDA, Fernando Dias Menezes de. Responsabilidade extracontratual do Estado por atos lícitos: ensaio em homenagem a Guido Soares. In: CASELLA, Paulo Borba et al. Direito internacional, humanismo e globalidade. São Paulo: Atlas, 2008, p. 21. 
inerente à finalidade de preservação do direito; outra diz respeito ao âmbito da indenização para os casos de sacrifícios, ou seja, se tal incluiria somente o equivalente patrimonial do direito ou se abrangeria uma indenização mais ampla, incluindo os lucros cessantes.

Com efeito, conforme disposição do artigo $5^{\circ}$, inciso XXIV da CF, a desapropriação - modalidade extrema de sacrifício - somente se efetua com o pagamento de justa e prévia indenização em dinheiro, salvo as exceções dispostas no próprio Texto Fundamental. Tem-se assim que o Poder Constituinte Originário previu um determinado regime jurídico para o ato destinado ao sacrifício do direito de propriedade consistente na desapropriação, a qual é compreendida pelos doutrinadores pátrios como limitação que afeta o caráter perpétuo da propriedade, porque é o meio pelo qual o Poder Público determina a transferência compulsória da propriedade particular para o seu próprio patrimônio ou de seus delegados ${ }^{125}$. Não poderia, assim, o legislador prever um regime menos favorável para esse sacrifício, sob pena de flagrante inconstitucionalidade.

Haveria que se diferenciar, contudo, a desapropriação da requisição extraordinária de bens prevista no artigo $5^{\circ}$, inciso XXV da $\mathrm{CF}$, hipótese em que a afetação do uso da propriedade particular é realizada em circunstância anormal, ou seja, no caso de iminente perigo público, onde o Poder Público pode fazer uso da propriedade particular, assegurado o pagamento de indenização ulterior, se houver dano.

Uma inquietação residiria, no entanto, em se considerar apenas os atos que transferem a titularidade da propriedade do particular ao Estado sujeitos ao regime jurídico previsto no citado dispositivo constitucional. É de se questionar se os demais atos que propõem e destinam-se à imposição de um sacrifício, em condições normais, ainda que não configurem a modificação do domínio, deveriam ser precedidos de prévia e justa indenização em dinheiro.

Por certo que, como já se afirmou, a necessidade de indenização está atrelada à proteção jurídica de que dispõe o direito de propriedade no ordenamento pátrio. E é exatamente isso o que leva a defender que o regime da desapropriação deve ser aplicado aos demais tipos de sacrifícios destinados ao aniquilamento total ou parcial do conteúdo do direito de propriedade, posto que essa indenização, esse dever de pagamento do equivalente patrimonial não está ligado à necessidade de incorporação do bem ao

${ }^{125}$ SILVA, José Afonso da. Curso de direito constitucional positivo. 32. ed. São Paulo: Malheiros, 2009, p. 281. 
patrimônio estatal, mas sim a uma diminuição substanciosa das faculdades que lhes são inerentes ou mesmo sua total supressão.

Há quem defenda, como Maurício Jorge Pereira da Mota, de que no direito brasileiro a desapropriação não se coaduna com o conceito alargado de expropriação, abrangendo expropriações não translativas da propriedade ou expropriações de valor ${ }^{126}$.

Edmir Netto de Araújo, ao promover estudo sobre a forma em que a desapropriação foi considerada nos textos constitucionais brasileiros, conclui que ora foi considerada como forma originária de aquisição da propriedade, ora como forma de perda da propriedade, ou ainda como substituição imposta pelo Poder Público do seu equivalente em dinheiro, operando simultaneamente sua transferência para o domínio público ${ }^{127}$. Aduz, ao final, que a desapropriação (hoje) é um procedimento pelo qual o Poder Público ou seus delegados, iniciando por prévia declaração de utilidade pública, necessidade pública ou interesse social, impõem ao proprietário pessoa física ou jurídica, a perda ou retirada de um bem de seu patrimônio, substituindo-o pela justa indenização que, em regra, será prévia e em dinheiro, salvo as exceções previstas na Constituição Federal, bem esse que se incorporará, também em regra, ao patrimônio do expropriante ${ }^{128}$.

Entende-se, contudo, que não haveria justificativa para adotar o procedimento da desapropriação tão só e unicamente para as hipóteses em que ocorre a aquisição do bem pelo expropriante. Não haveria justificativa jurídica razoável para diferenciar duas hipóteses em que o ato estatal destina-se à violação do patrimônio - uma na qual ocorre a aquisição da propriedade pelo Estado e outra não - de modo a possibilitar a atribuição de regimes jurídicos diferenciados. O que importa é o ato direcionado à violação do direito patrimonial e a necessidade de sua proteção, dada a configuração jurídica do referido direito como um direito fundamental e considerando, especialmente, que a garantia da propriedade é um complemento e um aspecto da liberdade humana, pois ela é o fundamento econômico da vida de muitos homens ${ }^{129}$.

\footnotetext{
${ }^{126}$ MOTA, Maurício Jorge Pereira da. Responsabilidade civil do Estado Legislador. Rio de Janeiro: Lúmen Júris, 1999, p. 215.

${ }^{127}$ Cf. ARAÚJO, Edmir Netto de. Curso de Direito Administrativo. 4. ed. São Paulo: Saraiva, 2009 , p. 1040.

128 Ibidem, pp. 1023-1024. No mesmo sentido DI PIETRO, Maria Sylvia Zanella. Curso de Direito Administrativo. 22. ed. São Paulo: Atlas, 2009, p. 159.

${ }_{129}$ MEDEIROS, Rui. Ensaio sobre a responsabilidade civil do Estado por actos legislativos. Coimbra: Almedina, 1992, p. 250.
} 
Concorda-se, assim, mais uma vez, com Carlos Ari Sundfeld que, partindo de uma concepção ampla do fenômeno da expropriação - justificado em razões históricas ${ }^{130}$, o qual abrangeria não só os atos de transferência de bens imóveis para o Estado, mas também qualquer forma de mutilação, em qualquer grau, do direito de propriedade e incluiria, ainda, não só restrições aos bens imóveis, mas qualquer tipo de bens -, defende que em virtude da proteção conferida ao direito de propriedade na Carta Constitucional, segue-se a impossibilidade de alguém ter seu patrimônio sacrificado, total ou parcialmente, temporária ou definitivamente, senão pela via expropriatória ${ }^{131}$.

Para além do reconhecimento da imprescindível indenização, esta deve, ainda, ser prévia, posto que a imposição de um sacrifício (ato estatal legitimamente destinado ao aniquilamento), o qual pressupõe a afetação de forma anormal do conteúdo essencial do direito, para determinado número de pessoas (especialidade), ainda que não acarrete a transferência da propriedade do bem, pode implicar o total esvaziamento do conteúdo do direito patrimonial, que se encontra garantido no direito de propriedade.

A admissão de um conteúdo amplo do direito de propriedade, que abrange não só a titularidade de um particular sobre um bem, mas também a garantia e o direito ao aproveitamento desse mesmo bem, implica a admissão da tese de que não se viola o referido direito simplesmente com a transferência do domínio, mas também se revela um sacrifício quando se diminui de tal forma o conteúdo do direito de propriedade, que se torna inviável sua utilização econômica pelo cidadão.

Essa premissa é importante porque a partir dela, tem-se que, no ordenamento jurídico brasileiro, o sacrifício de direito, prevendo o pagamento de prévia indenização, causa dano lícito, legitimamente permitido pelo ordenamento jurídico ${ }^{132}$. Não raras vezes,

\footnotetext{
${ }^{130}$ Segundo o autor, originalmente, a expropriação era entendida tão só como modo de transferência de bens imóveis para o Estado, sendo esse fenômeno explicável em virtude de dois fatores históricos: a) a propriedade imobiliária era, até o final do século passado, a base fundamental da riqueza; b) o Estado intervinha muito restritamente na vida social: apenas as obras públicas - como a construção de estradas de ferro - justificava a expropriação. Contudo, com a evolução econômica, a riqueza dissociou-se dos bens materiais e, em paralelo, o Estado ampliou sua atuação, interferindo na economia, no urbanismo, etc., donde a mais intensa fricção entre direitos privados e interesses públicos. Daí a necessidade de conceber a expropriação de modo mais amplo, dado que isso seria uma decorrência natural da finalidade perseguida pela Constituição quanto à proteção do direito de propriedade, qual seja, assegurar preservar o instrumento essencial da atuação dos indivíduos na economia. Cf. SUNDFELD, Carlos Ari. Direito Administrativo Ordenador. São Paulo: Malheiros, 2003, p. 96.

${ }^{131}$ SUNDFELD, Carlos Ari. Direito Administrativo Ordenador. São Paulo: Malheiros, 2003, p. 99 et. seq.

${ }^{132}$ Segundo Maurício ZOCKUN a prévia indenização faz com que o dano provocado pelo ato lícito seja lícito e não ilícito, de modo que assim não se pratica uma lesão à ordem jurídica. Cf. ZOCKUN, Maurício. $A$ matriz constitucional da responsabilidade do Estado, a responsabilidade do Estado por atos legislativos e a
} 
contudo, o ato estatal, mesmo destinado ao aniquilamento do direito, não prevê o pagamento da prévia indenização, ocasionando, assim, um dano antijurídico, apto a gerar a responsabilidade civil do Estado. $\mathrm{O}$ ato estatal, mesmo dedicado ao aniquilamento, gera a responsabilidade, na medida em que, sob a aparência de lícito, na verdade desrespeita o regime jurídico imposto pela Constituição para o aniquilamento, caracterizando assim um dano antijurídico. Tal premissa será considerada, especialmente, ao se tratar da responsabilidade do Estado por atos legislativos constitucionais, tema a ser desenvolvido mais adiante neste trabalho.

Outra questão importante a respeito dos sacrifícios de direito relaciona-se ao âmbito dos danos indenizáveis.

É certo que, tendo como objetivo criar uma nova situação patrimonial correspondente e de valor igual à perda sofrida, já que é o próprio sistema jurídico que autoriza o sacrifício, tal como ocorre através da desapropriação, a indenização consubstancia em importância o valor da perda patrimonial suportada, ou seja, abrange apenas o valor que habilita o lesado a adquirir outro bem perfeitamente equivalente ao atingido, alcançando apenas os danos emergentes, posto que esta é a exata medida prescrita pelo sistema para o direito. A indenização, assim, deve corresponder a quantia que preencha no patrimônio do expropriando o vazio deixado pelo desfalque sofrido com a desapropriação ${ }^{133}$.

Dúvida existe, no entanto, seja na seara doutrinária ou na jurisprudencial, quanto a determinar se aquilo que se deixa de auferir, ou seja, os lucros cessantes, devem também compor a indenização. Para Luis Manoel Fonseca Pires, dado o alcance dos lucros cessantes, esses pressupõem para sua ocorrência a violação de um direito, ou seja, a responsabilidade patrimonial do Estado ${ }^{134}$.

Já para José Carlos de Moraes Salles, por exemplo, cuja posição se compartilha, haveria que se efetuar o pagamento dos lucros cessantes, dado o fato de que a Constituição fala em justa indenização no seu artigo $5^{\circ}$, inciso XXIV. Todavia, tanto os danos

obrigatoriedade de prévia indenização. Tese (Doutorado em Direito). Faculdade de Direito - Pontifícia Universidade Católica de São Paulo, São Paulo, 2009, p. 46.

${ }^{133}$ Cf. SALLES, José Carlos de Moraes. A desapropriação à luz da doutrina e da jurisprudência. 6. ed. São Paulo: RT, 2009, p. 447.

${ }^{134}$ PIRES, Luis Manuel Fonseca. A propriedade privada em área de proteção ambiental, pp. 32-53. In: PIRES, Luis Manuel Fonseca e ZOCKUN, Maurício. (Coord.). Intervenções do Estado. São Paulo: Quartier Latin, 2008, p. 41. 
emergentes quanto os lucros cessantes devem ser efetivos e não apenas prováveis, devendo ser, por isso, cumpridamente demonstrados no feito expropriatório ${ }^{135}$.

Como se aduziu, entretanto, a matéria está longe de ser compreendida de forma pacífica nos tribunais superiores, pois há decisões que afirmam que não caberia o pagamento de lucros cessantes no cômputo da indenização devida ao expropriado, conforme se observa do julgamento do Recurso Extraordinário $\mathrm{n}^{\circ}$ 63.926, Relator Ministro Amaral Santos, em que o Supremo Tribunal Federal, por unanimidade, decidiu que "não cabe o pagamento de lucros cessantes no cômputo da indenização devida ao

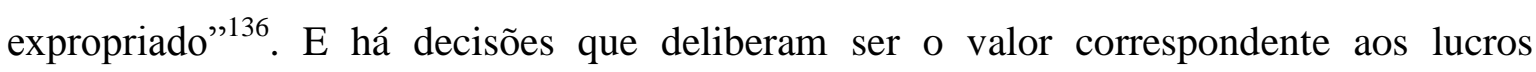
cessantes devido ao expropriado, como se observa do Recurso Especial $n^{\circ} 654.321$ do Superior Tribunal de Justiça ${ }^{137}$, Relatora Ministra Eliana Calmon, em que houve reconhecimento do direito à indenização do particular que, embora ainda não estivesse explorando uma jazida mineral para a qual havia obtido licença para legítima tanto, teve, posteriormente, inviabilizada tal exploração por ato do Poder Público, sendo-lhe devido, por isso, o pagamento de valores a título de lucros cessantes ${ }^{138}$.

Ainda que distante o entendimento pacífico da questão, sustenta-se o ponto de vista de que seria devido o pagamento das perdas e danos sofridas pelo particular cujo direito patrimonial foi sacrificado, de modo que tal característica não se diferenciaria da hipótese de reparação por dano antijurídico (responsabilidade civil do Estado).

No entanto, face ao que será desenvolvido ao longo deste capítulo, haveria que se diferenciar as hipóteses de sacrifícios de direitos daquelas relativas à responsabilidade do Estado por ato lícito, pois: a) nos sacrifícios de direito, a indenização deve ser prevista de

\footnotetext{
${ }^{135}$ SALLES, José Carlos de Moraes. Op. cit., p. 452.

${ }^{136}$ Supremo Tribunal Federal. Recurso Extraordinário no 63.296. Primeira Turma. Relator Ministro Amaral Santos. Revista de Direito Administrativo, Rio de Janeiro, n. 102, out./dez., 1970, p. 192-194.

137 Superior Tribunal de Justiça. Ementa: "Desapropriação. Jazida. Areia. Cascalho. Saibro. Trata-se de desapropriação para fins de reforma agrária em que se discute o cabimento de indenização de jazida mineral que, no caso, teve o seu licenciamento renovado dois meses antes da imissão do Incra na posse, muito embora, na ocasião, não houvesse exploração na área. A Turma, por maioria, ao prosseguir o julgamento, entendeu que, havendo legítima autorização, licença ou concessão, uma vez inviabilizada pelo Poder Público a exploração da jazida, há direito à indenização, ainda que não exercida a atividade de exploração naquele momento. Trata-se na verdade, de indenização por lucros cessantes. Precedentes citados do STF: Ag no RE 140.254-SP, DJ 6/6/1997, e RE 315.135-RS, DJ 7/6/2002; do STJ: REsp 33.832-SP, DJ 28/6/1993, e REsp 77.129-SP, DJ 2/12/1996". Recurso Especial 654.321. Relatora Ministra Eliana Calmon. 2a Turma. Julgado em 27.10.2009. Informativo de jurisprudência $\mathrm{n}^{\circ} 413$ do STJ. Disponível em: http://www.stj.jus.br/SCON/infojur/doc.jsp. Acesso em 08/12/09.

${ }^{138}$ Sobre a referida divergência doutrinária e jurisprudencial sobre o tema, conferir em FERRAZ, Sérgio. Desapropriação: indicações de doutrina e jurisprudência. Rio de Janeiro: Forense, 1972, pp. 57-58.
} 
forma prévia, justa e em dinheiro, tal qual o regime previsto para a realização da desapropriação no direito brasileiro, já que o ato estatal destina-se ao aniquilamento total ou parcial do direito; b) o sacrifício pressupõe a ocorrência de um dano legítimo permitido e, por vezes, querido pela ordem jurídica - enquanto que a responsabilidade pressupõe a ocorrência de um dano antijurídico para sua atuação, o qual é causado também de forma reflexa; c) a responsabilidade tem natureza além de reparatória, também sancionatória, enquanto que a indenização do sacrifício de direito não detém a última característica.

Essas questões serão ainda retomadas por ocasião da análise dos atos legislativos constitucionais danosos, um dos temas a serem enfrentados neste trabalho. 


\section{O REGIME JURÍDICO DA RESPONSABILIDADE CIVIL DO ESTADO NO ORDENAMENTO JURÍDICO BRASILEIRO}

\subsection{SÍNTESE DA EVOLUÇÃO NORMATIVA DA RESPONSABILIDADE CIVIL DO ESTADO NO DIREITO BRASILEIRO}

No Brasil, a Constituição Imperial de 1824 consagrava em seu artigo 179, inciso XXIX, a responsabilidade dos empregados públicos pelos abusos e omissões praticados no exercício de suas funções e por não fazerem efetivamente responsáveis os seus subalternos. Embora excluída a responsabilidade do Imperador, isso não significava, contudo, a irresponsabilidade civil do Estado, que restava designada em outros diplomas normativos como, por exemplo, o Decreto $\mathrm{n}^{\mathrm{o}} 1.930$, de 26 de abril de 1857 (estradas de ferro), o Decreto $\mathrm{n}^{\mathrm{o}} 3.453$, de 20 de abril de 1865 (oficiais de registro), entre outros ${ }^{139}$.

O advento da República não modificou de imediato a orientação constitucional sobre a matéria, de modo que a responsabilidade do funcionário foi mantida, nos mesmos moldes, no artigo 82 da Constituição da República de 1891, o que não significava, contudo, a irresponsabilidade do Estado, posto que se entendia haver solidariedade do Estado em relação aos atos de seus agentes ${ }^{140}$.

Alteração sobreveio com o Código Civil de 1916, diploma normativo que prescreveu a responsabilidade civil estatal nos seguintes termos:

Art. 15. As pessoas jurídicas de Direito Público são civilmente responsáveis por atos de seus representantes que nessa qualidade causem danos a terceiros, procedendo de modo contrário ao direito ou faltando a dever prescrito em lei, salvo o direito regressivo contra os causadores do dano.

Tratava-se de dispositivo que indicava claramente a existência da responsabilidade civil estatal, embora reclamasse a demonstração de culpa para sua atuação, seja esta a culpa civil ou a falta do serviço, o que constituía ainda um grande encargo para o administrado lesado pelo Poder Público. A redação ambígua do dispositivo, no entanto, causava certa controvérsia na doutrina quanto ao regime da responsabilidade, posto que alguns já sustentavam que o artigo abarcava uma responsabilidade objetiva.

${ }^{139}$ Cf. ARAÚJO, Edmir Netto de. Curso de Direito Administrativo. 4. ed. São Paulo: Saraiva, 2009, p. 758.

${ }^{140}$ Cf. MELlo, Celso Antônio Bandeira de. Curso de Direito Administrativo. 26. ed. São Paulo: Malheiros, 2009, p. 1018. 
$\mathrm{Na}$ linha evolutiva, adveio a Constituição de 1934, que estabeleceu a responsabilidade do Estado, na figura da Fazenda Pública, ainda de forma solidária com a do funcionário público. Pautava-se também em princípios de Direito Privado, sendo pressuposto para sua atuação a verificação da negligência do funcionário e de "abusos ou omissões práticos no exercício de suas funções, e por não fazerem efetivamente responsáveis os seus subalternos".

O tema foi objeto de tratamento inovador, contudo, na Carta Constitucional de 1946, posto que o artigo 194 consagrou a responsabilidade do Estado de forma objetiva, não fazendo alusão a culpa alguma do funcionário, in verbis:

Art. 194. As pessoas jurídicas de direito público interno são civilmente responsáveis pelos danos que os seus funcionários, nessa qualidade, causarem a terceiros.

Parágrafo único. Caber-lhes-á ação regressiva contra os funcionários causadores do dano, quando tiver havido culpa destes.

As disposições previstas na Carta Constitucional de 1967 e na Emenda nº 01, de 1969, reproduziram a mesma orientação, estatuindo, a primeira, no seu artigo 105, a referida responsabilidade de modo objetivo, com direito de regresso contra o funcionário nos casos de dolo ou culpa e a segunda repetindo o dispositivo quase que de modo literal.

A Constituição de 1988, seguindo a mesma trilha dos Textos Constitucionais anteriores, previu no artigo $37, \S 6^{\circ}$, a responsabilidade civil estatal de moldes objetivos, consagrando também em seu artigo $5^{\circ}$, inciso $\mathrm{X}$, a responsabilidade por dano moral, independentemente da personalidade jurídica da pessoa que provoca o dano.

A redação do dispositivo (artigo 37, §6 $6^{\circ}$, bem como o regime jurídico por ele estabelecido serão estudados a seguir.

\subsection{O CONTEÚDO DO ARTIGO 37, $\S 6^{\circ}$, DA CONSTITUIÇÃO}

No ordenamento jurídico brasileiro, a responsabilidade civil do Estado, primado do princípio republicano, está disposta expressamente no artigo $37, \S 6^{\circ}$, do Texto Maior, cuja redação é a seguinte:

Art. 37.

(...)

$\S 6^{\circ}$. As pessoas jurídicas de direito público e as de direito privado prestadoras de serviços públicos responderão pelos danos que seus 
agentes, nessa qualidade, causarem a terceiros, assegurado o direito de regresso contra o responsável nos casos de dolo ou culpa.

Trata-se de norma jurídica específica consagrada no texto constitucional, na qual o termo responsabilidade diz respeito à situação jurídica a que é submetido o Poder Público, em que deve responder com seu patrimônio por um dano decorrente do exercício de quaisquer de suas funções, seja ela a administrativa, a jurisdicional ou a legislativa. Referese à responsabilidade de natureza patrimonial, dita civil, em âmbito extracontratual, ou seja, quando a obrigação de reparação do Poder Público não decorre de um contrato, atribuída ao Estado ou a quem lhe faça as vezes.

De se registrar, ainda, que a Constituição de 1988 previu a responsabilidade do Estado em outros dois dispositivos: o artigo $5^{\circ}$, inciso LXXV, que trata do direito à indenização por erro judiciário e por prisão além do tempo previsto na sentença, e no artigo 21, XXIII, "c", que veicula a responsabilidade estatal por danos nucleares.

Será objeto de estudo, no entanto, apenas o disposto no artigo $37, \S 6^{\circ}$, da Carta Maior, já que o tema desta dissertação refere-se à responsabilidade do Estado por atos legislativos.

Segundo a doutrina pátria, esse preceito constitucional, seguindo a evolução histórica do instituto da responsabilidade civil estatal no direito brasileiro, reafirma o princípio da responsabilidade objetiva, que prescinde da investigação da culpa ou dolo do agente, sendo o dano um dos pressupostos para o seu nascimento. Proclama também, a exemplo das Constituições anteriores, o direito de regresso do Estado contra o responsável, nos casos de dolo ou culpa.

Acolhe a teoria do risco administrativo, também já consagrada desde a Carta Política de 1946, fazendo emergir da mera ocorrência de ato lesivo causado à vítima pelo Estado o dever de indenizá-la ${ }^{141}$. Contudo, quanto a este ponto, como será visto, não há

\footnotetext{
${ }^{141}$ Supremo Tribunal Federal. Ementa: “(...) A teoria do risco administrativo, consagrada em sucessivos documentos constitucionais brasileiros desde a Carta Política de 1946, confere fundamento doutrinário à responsabilidade civil objetiva do Poder Público pelos danos a que os agentes públicos houverem dado causa, por ação ou por omissão. Essa concepção teórica, que informa o princípio constitucional da responsabilidade civil objetiva do Poder Público, faz emergir, da mera ocorrência de ato lesivo causado à vítima pelo Estado, o dever de indenizá-la pelo dano pessoal e/ou patrimonial sofrido, independentemente de caracterização de culpa dos agentes estatais ou de demonstração de falta do serviço público. Os elementos que compõem a estrutura e delineiam o perfil da responsabilidade civil objetiva do Poder Público compreendem (a) a alteridade do dano, (b) a causalidade material entre o eventus damni e o comportamento positivo (ação) ou negativo (omissão) do agente público, (c) a oficialidade da atividade causal e lesiva, imputável a agente do
} 
entendimento unânime da doutrina, sendo que alguns autores, nos casos de comportamentos omissivos do Estado, compreendem que se aplica a responsabilidade pela teoria da culpa ou falta do serviço, seja porque este não funcionou, quando deveria normalmente funcionar, seja porque funcionou mal ou funcionou tardiamente ${ }^{142}$.

Explica Maria Sylvia Zanella Di Pietro que o reconhecimento da responsabilidade objetiva do Estado é entendimento extraído da letra da lei de forma excludente: uma vez que só se exige culpa ou dolo para o direito de regresso contra o funcionário, logo é porque não se quis fazer a mesma exigência para as pessoas jurídicas - situação que tipifica, então, a responsabilidade objetiva ${ }^{143}$.

Marçal Justen Filho destaca, ainda, que o preceito constitucional abarca uma pluralidade de regimes jurídicos para a responsabilidade civil estatal, cabendo uma responsabilidade regida por princípios e regras de Direito Público para as pessoas jurídicas de direito público e para as de direito privado prestadoras de serviços públicos, e uma responsabilidade civil própria da iniciativa privada (regida pelo Direito Privado) que é aplicada às entidades integrantes da Administração indireta, dotadas de personalidade jurídica de direito privado e exploradoras de atividade econômica ${ }^{144}$.

Interessa, todavia, apenas a análise do regime jurídico que é imputado às pessoas jurídicas de direito público, como definidas nos artigos $1^{\circ}$ e 18 da Constituição Federal, bem como no artigo 41 do Código Civil, dado que o foco do presente estudo refere-se aos danos decorrentes da atividade legislativa, a qual é titularizada pelas referidas pessoas jurídicas (artigos 22, 24, 25 e 30 da CF), não sendo oportuno, por isso, problematizar o tema com relação às pessoas jurídicas prestadoras de serviços públicos ou exploradoras de atividade econômica.

Poder Público, que tenha, nessa condição funcional, incidido em conduta comissiva ou omissiva, independentemente da licitude, ou não, do comportamento funcional (RTJ 140/636) e (d) a ausência de causa excludente da responsabilidade estatal (RTJ 55/503 - RTJ 71/99 - RTJ 91/377 - RTJ 99/1155 - RTJ 1 31/417)". RE n. 109.615-2/ RJ. Relator: Ministro Celso de Mello. $1^{\text {a }}$ Turma. j. 28/5/96. DJ 02/08/96. Disponível em: http://www.stf.jus.br/portal/inteiroTeor/obterInteiroTeor.asp?numero=109615\&classe=RE. Acesso em 07.12.09.

${ }^{142}$ Cf. MELLO, Celso Antônio Bandeira de. Curso de Direito Administrativo. 26. ed. São Paulo: Malheiros, 2009, p. 1022. Também reconhecendo que, embora seja regra a responsabilidade objetiva do Estado, fundada na teoria do risco administrativo, resta ainda espaço apara a responsabilidade subjetiva do Estado baseada na culpa anônima ou falta de serviço, ver CAVALIERI FILHO, Sérgio. Programa de responsabilidade civil. 8. ed. São Paulo: Atlas, 2008, p. 255.

${ }^{143}$ DI PIETRO, Maria Sylvia Zanella. Direito Administrativo. 22. ed. São Paulo: Altas, 2009, p. 645.

144 JUSTEN FILHO, Marçal. A responsabilidade do Estado. In: FREITAS, Juarez (Org.). Responsabilidade civil do Estado. São Paulo: Malheiros, 2006, pp. 228-229. 
A doutrina afirma, categoricamente, que essa imposição de reparar os danos causados a terceiros em decorrência de comportamentos estatais, abrange atos comissivos ou omissivos, materiais ou jurídicos, lícitos ou ilícitos, desde que imputáveis aos agentes públicos $^{145}$.

Discorrer-se-á sobre todas essas características ao longo do presente capítulo, não se seguindo, contudo, necessariamente, a ordem em que foram acima enunciadas.

\subsubsection{Atos comissivos ou omissivos, materiais ou jurídicos, lícitos ou ilícitos}

A responsabilidade estatal inclui comportamentos comissivos ou omissivos, conforme sejam originados de uma ação ou omissão do Estado, respectivamente, materiais (fatos jurídicos) ou jurídicos (declaração de vontade feita na forma que o ordenamento jurídico prescreve para produzir efeitos jurídicos determinados) ${ }^{146}$.

No repertório do STF, tem-se como regra geral o reconhecimento da responsabilidade objetiva pela atividade comissiva do Estado, ilícita ou lícita ${ }^{147}$, sendo admissível, no entanto, a ocorrência de hipóteses excludentes.

No tocante às omissões, observa-se que não há consenso entre os juristas quanto ao regime de responsabilidade aplicável - quanto a tratar-se de responsabilidade subjetiva ou objetiva -, não havendo, nem mesmo, uniformidade nas decisões do Supremo Tribunal Federal sobre a questão.

A despeito da referida divergência, será tratado no presente trabalho apenas da responsabilidade civil do Estado pelos atos legislativos (atos comissivos) e não serão abordadas as hipóteses de omissão legislativa que ensejam a responsabilidade civil estatal,

\footnotetext{
${ }^{145}$ Cf. DI PIETRO, Maria Sylvia Zanella. Curso de Direito Administrativo. 22. ed. São Paulo: Atlas, 2009, p. 639. No mesmo sentido: MELLO, Celso Antonio Bandeira de. Curso de Direito Administrativo. 26. ed. São Paulo: Malheiros, 2009, p. 1022. ARAÚJO, Edmir Netto de. Curso de Direito Administrativo. 4. ed. São Paulo: Saraiva, 2009, p. 762. MODESTO, Paulo. Responsabilidade do Estado pela Demora na Prestação Jurisdicional. Revista Eletrônica sobre a Reforma do Estado (RERE), Salvador, Instituto de Direito Público, $\mathrm{n}^{\mathrm{o}}$ 13, março/abril/maio de 2008, Disponível em: 〈http://www.direitodoestado.com.br/rere.asp>. Acesso em: 09 de dezembro de 2009, p. 11.

${ }^{146}$ ARAÚJO, Edmir Netto de. Curso de Direito Administrativo. 4. ed. São Paulo: Saraiva, 2009, p. 762.

${ }^{147}$ Sobre a responsabilidade por atos lícitos, confira-se: “(...) É da jurisprudência do Supremo Tribunal que, para a configuração da responsabilidade objetiva do Estado não é necessário que o ato praticado seja ilícito". STF, AgR RE 456.302. Relator: Ministro Sepúlveda Pertence. Primeira Turma. Julgado em 06/02/2007. DJ 16-03-2007. Disponível em: http://www.stf.jus.br/portal/inteiroTeor/obterInteiroTeor.asp?numero=456302\&classe=RE-AgR. Acesso em: 08/12/09.
} 
razão pela qual será feita neste item do trabalho apenas breve referência à responsabilidade por omissão, a fim de não deixar o leitor desprovido de qualquer parâmetro a respeito da discussão que se trava no cenário jurídico brasileiro.

No âmbito da doutrina, Celso Antonio Bandeira de Mello ${ }^{148}$ defende que se aplica a regra da responsabilidade subjetiva pela omissão estatal. Isso porque, segundo o autor, na omissão, a rigor o Estado não causa o dano, apenas o propicia. A omissão ou a deficiência do Poder Público no exercício de determinada atividade é condição do dano e não sua causa, pois essa última constitui-se no fator que positivamente gera o resultado, enquanto que a condição é o evento que não ocorreu, mas que se tivesse ocorrido teria impedido o resultado. No entendimento do jurista o artigo $37, \S 6^{\circ}$, da $\mathrm{CF}$ faz referência à forma objetiva apenas quanto aos danos causados diretamente pelo Poder Público, isto é, aos danos aos quais os agentes que atuam em nome do Estado deram causa. Ademais, argumenta que não seria razoável o Estado responder objetivamente pelos danos que não causou, mas que outros causaram.

Somente se estivesse por direito obrigado a impedir os danos, ou seja, se o Estado tivesse o dever de agir e não o fez ou o fez de forma deficiente, havendo, portanto, negligência no ato, é que se pode falar então em responsabilidade, razão pela qual se requer a demonstração da culpa, ainda que essa não seja personificada (culpa anônima), de modo que a responsabilidade estatal nos casos de omissão seria subjetiva ${ }^{149}$.

Paulo Modesto ${ }^{150}$, no entanto, diverge de tal opinião. Segundo o autor, embora para aferir-se a omissão que constitui fato jurídico relevante para a produção de lesão ressarcível leve-se em conta sempre alguma manifestação de culpa - já que a omissão, em termos jurídicos, inclui e embute a violação do dever de observar a conduta legal obrigatória, o que pode traduzir-se em culpa ou consciência na contrariedade ao dever de cuidado exigido - ainda assim tal não importa em exigir do administrado a prova de culpa, ou em excepcionar a norma constitucional enunciada no artigo $37, \S 6^{\circ}$, da Constituição da República.

${ }^{148}$ MELLO, Celso Antônio Bandeira de. Curso de Direito Administrativo. 26. ed. São Paulo: Malheiros, 2009 , p. 1022.

${ }^{149}$ MELLO, Celso Antônio Bandeira de. Curso de Direito Administrativo. 26. ed. São Paulo: Malheiros, 2009 , p. 1022.

${ }^{150}$ MODESTO, Paulo. Responsabilidade do Estado pela Demora na Prestação Jurisdicional. Revista Eletrônica sobre a Reforma do Estado (RERE), Salvador, Instituto de Direito Público, $\mathrm{n}^{\circ}{ }^{13}$, março/abril/maio de 2008, Disponível em: <http://www.direitodoestado.com.br/rere.asp〉. Acesso em: 09 de dezembro de 2009, p. 13 et seq. 
No seu entendimento a responsabilidade pela omissão também é objetiva e a escusa ocorre com a demonstração do rompimento do nexo causal, o qual se caracteriza através da demonstração do atendimento razoável dos deveres sintetizados na norma de competência ou com a demonstração da existência de concausas.

Em relação ao problema da responsabilidade por omissão do Estado, observa Yussef Said Cahali ${ }^{151}$ - de forma muito apropriada, entende-se - que é a elasticidade do conceito de exigibilidade do ato estatal que induz alguns autores a pensarem sob a perspectiva da necessidade de aferição da culpa para atuação do instituto. Mas, como reconhece o autor, baseado nas lições de João Donizete Gandini e Diana Silva Salomão, não é necessário transmudar a responsabilidade de objetiva em subjetiva para que a Administração se desvincule do dever de indenizar, bastando que ela demonstre que não tinha o dever de agir e que, portanto, a sua conduta não foi, do ponto de vista jurídico, causa do evento danoso.

No entanto, para o doutrinador - cuja posição se compartilha - a aferição do dever jurídico descumprido somente pode ser identificável concretamente, isto é, diante de uma hipótese concreta, sendo que a simples conduta omissiva não é suficiente para desencadear a responsabilidade, havendo necessidade de que esta conduta tenha dado causa ou concorrido para a ocorrência do acidente ${ }^{152}$.

A dificuldade que se verifica na omissão, portanto, diz respeito à aferição da possibilidade de agir: tem que se estar diante de uma conduta que além de exigível da Administração, seja possível, razão pela qual tal somente pode ser avaliado diante do caso concreto.

$\mathrm{Na}$ jurisprudência, conforme salientado acima, a questão também não está pacificada. O Supremo Tribunal Federal já considerou que, nos casos de omissão, o Estado responde objetivamente, como na situação em que uma omissão estatal, caracterizada pela ausência do cumprimento do dever constitucional de guarda, propiciou a morte de detento por outro preso dentro de cadeia pública ${ }^{153}$, mas já havia compreendido,

${ }^{151}$ CAHALI, Yussef Said. Responsabilidade civil do Estado. 3. ed. São Paulo: Revista dos Tribunais, 2007, pp. 221-222.

${ }^{152}$ CAHALI, Yussef Said. Responsabilidade civil do Estado. 3. ed. São Paulo: Revista dos Tribunais, 2007, p. 222.

${ }^{153}$ STF. Ementa: "Responsabilidade objetiva do Estado. Morte de detento por outro preso. 1. Detento assassinado por outro preso. Responsabilidade objetiva do Estado de reparar o dano. 2. Agravo regimental a 
anteriormente, em acórdão cujo voto paradigma foi proferido pelo Ministro Relator Carlos Velloso, que no caso de detento ferido por outro detento dentro de delegacia de polícia, a responsabilidade do Estado surgia apenas de modo subjetivo, de modo que caberia ao particular demonstrar a culpa do serviço ${ }^{154}$.

Em que pese tal divergência, reitera-se que na omissão caberá a avaliação no caso concreto do dever de agir estatal e de suas efetivas possibilidades, o que não conduz, todavia, à afirmação de que nessas hipóteses tem-se caracterizada a necessidade de o particular demonstrar a culpa do ente público para que se possa responsabilizá-lo.

Quanto à possibilidade de responsabilização decorrente de ato ilícito ou lícito, reporta-se ao Capítulo 2 do presente trabalho, razão pela qual faz-se desnecessário retornar ao tema.

\subsubsection{Dano}

No capítulo anterior salientou-se que somente o dano antijurídico dá margem à responsabilização estatal, havendo necessidade de que este se caracterize pela afetação prejudicial de um direito, ou seja, deve haver um prejuízo jurídico e não meramente patrimonial; que ele seja certo, podendo ser atual ou futuro; e nos casos de atos lícitos, que o dano seja, ainda, anormal e especial.

Em regra, os efeitos danosos incidem no patrimônio atual da vítima (danos emergentes), mas é possível que esses efeitos também possam incidir no futuro (lucros cessantes), o que não significa dizer, contudo, que a reparação deva se estabelecer em relação ao dano hipotético, uma vez que o prejuízo, para ser reparável, conforme dito anteriormente, deve ser certo, situando-se numa zona de grande probabilidade de ocorrência, de acordo com as circunstâncias peculiares do caso concreto.

que se nega provimento". Ag R RE no 466.322. Relator: Ministro Eros Grau. 2 ${ }^{\mathrm{a}}$ Turma. Julgado em 13/03/2007. DJ 27/04/07. Disponível em: http://www.stf.jus.br/portal/inteiroTeor/obterInteiroTeor.asp?numero=466322\&classe=RE-AgR. Acesso em 18.09.09. No mesmo sentido o RE 272.839. Relator: Ministro Gilmar Mendes. Segunda Turma, julgado em 01/02/2005. DJ 28/04/05. Disponível em: http://www.stf.jus.br/portal/inteiroTeor/obterInteiroTeor.asp?numero=272839\&classe=RE. Acesso em 18.09.09.

${ }^{154}$ STF. Ementa: "Responsabilidade civil do Estado. Ato omissivo do Poder Público: detento ferido por outro detento. Responsabilidade subjetiva. Culpa publicizada: falta do serviço. CF, ART. 37, §6”" RE $382.054-$ RJ. Relator: Ministro Carlos Velloso. 2a Turma. Julgado em 31.08.04. DJ 01.10.2004. Disponível em: http://www.stf.jus.br/portal/inteiroTeor/obterInteiroTeor.asp?numero=382054\&classe=RE. Acesso em: 09.12.09. 
Quanto à natureza da lesão, os danos podem ser tanto materiais quanto morais. A Constituição Federal, em seu artigo $5^{\circ}$, consagra no inciso V não apenas o direito de resposta ao agravo sofrido em virtude do exercício da liberdade por outrem, reconhecendo explicitamente o direito à indenização por dano moral ou à imagem. $\mathrm{O}$ inciso $\mathrm{X}$ do mesmo artigo também assegura, em virtude da inviolabilidade da intimidade, da vida privada, da honra e da imagem das pessoas, o direito à indenização por dano material ou moral decorrente de sua violação.

A distinção entre dano material e moral, entretanto, não decorre da natureza do direito, mas do efeito da lesão, de modo que tanto é possível ocorrer dano patrimonial em consequência de lesão a um bem não patrimonial como dano moral em resultado de ofensa a bem material.

As indenizações por dano material e por dano moral podem ser cumuladas, como já pacificou o Superior Tribunal de Justiça por meio da Súmula 37, cuja redação é a seguinte: "São cumuláveis as indenizações por dano material e por dano moral oriundas do mesmo fato".

O dano material corresponde ao prejuízo sofrido no patrimônio da vítima, enquanto que o dano moral não atinge tal patrimônio.

Não é qualquer abalo que se caracteriza como dano moral. Embora nem sempre fácil seja delimitar e reconhecer a sua ocorrência, pode-se dizer que o dano moral constitui a dor, o espanto, a emoção, a vergonha, a injúria física ou moral, em geral uma dolorosa sensação experimentada pela pessoa, atribuído à palavra dor o mais largo significado ${ }^{155}$.

Esse prejuízo coloca em causa o delicado problema da quantificação do valor da indenização. Os efeitos puramente psíquicos e sensoriais experimentados pela vítima do dano são de difícil avaliação para o estabelecimento de um critério objetivo a pautar-lhe a reparação pela ofensa sucedida.

Se o seu próprio conteúdo inviabiliza uma pura e simples equação matemática, tal não pode levar a objetar sua reparação, já que não se pode abandonar a vítima sem ao menos procurar amenizar o seu sofrimento com um quantum arbitrado prudentemente, apaziguando-lhe os ânimos.

${ }^{155}$ DIAS, José de Aguiar. Da responsabilidade civil. 11. ed. Rio de Janeiro: Renovar, 2006, p. 993. 
A reparação pecuniária de um dano moral não visa restabelecer o status quo ante, mas sim compensar, pela satisfação ou benefícios que possa proporcionar, a dor moral resultante do ato praticado. Sem dúvida de que tal indenização também tem um caráter punitivo, devendo por meio dela desestimular o ofensor à prática de outros atos nesse sentido.

Quanto à responsabilidade civil decorrente da atuação estatal, é de se observar que abrange tanto os danos materiais como os morais causados aos particulares, uma vez que a própria Constituição não distingue a reparação em virtude da pessoa jurídica ser de direito público ou privado. Também não caberia dizer que o Estado somente provoca abalos patrimoniais, posto que no exercício de suas atividades pode, como, por exemplo, numa revista, proceder com excessos vexatórios, acarretando dano moral.

Cabe ressaltar que hoje resta reconhecido, por meio da Súmula $227^{156}$ do Superior Tribunal de Justiça, que a pessoa jurídica também pode sofrer dano moral, em virtude do abalo de sua credibilidade, honestidade ou boa fama.

Nesse sentido, admitindo-se de forma ampla o direito à reparação pelo abalo sofrido, pode-se dizer que o Estado responde tanto por danos materiais quanto morais provocados pelos seus agentes a terceiros.

\subsubsection{Agentes}

Do disposto no artigo 37, $\S 6^{\circ}$, da Carta Magna, nota-se que o Poder Constituinte de 1988 preferiu utilizar a expressão agentes, que é bastante ampla, o que possibilitou abarcar não apenas os funcionários públicos, mas todos aqueles que de forma permanente, temporária ou acidental participam da atividade do Estado. A norma engloba, assim, toda pessoa física que exerce função pública (legislativa, administrativa ou judicial), com ou sem vínculo empregatício, em caráter definitivo ou transitório.

Inclui, portanto, os agentes políticos ${ }^{157}$, categoria esta que mantém com o Estado uma relação política, de representação e que ocupa os órgãos de administração superior,

\footnotetext{
156 "Súmula 227. A pessoa jurídica pode sofrer dano moral”

${ }^{157}$ Nos termos do voto do Ministro Relator Eros Grau, proferido por ocasião do julgamento do AgR no RE $\mathrm{n}^{\circ}$ 518.278-9, in verbis: “O Supremo Tribunal Federal, no julgamento RE n 228.977, Relator o Ministro Néri da Silveira, fixou entendimento no sentido de que os agentes políticos não agem em nome próprio, mas em nome do Estado, exercendo função eminentemente pública, de modo que não há como lhes atribuir
} 
como no caso dos parlamentares (senadores, deputados estaduais, deputados distritais e vereadores) ${ }^{158}$.

Todavia, é certo que o artigo $37, \S 6^{\circ}$ exigiu que os agentes agissem nessa qualidade para configurar a responsabilidade estatal. Logo, tem-se que o simples fato de ser agente público não é condição suficiente para desencadear a responsabilidade do Estado. A condição de atuar nessa qualidade revela que o agente deve estar no exercício de suas funções para possibilitar a imputação da responsabilidade ao Estado ${ }^{159}$.

Por sua vez, o exercício de suas funções não deve ser compreendido como o estar em serviço, podendo mesmo ocorrer a responsabilidade estatal ainda que o agente esteja fora do seu período de trabalho, bastando que tenha se utilizado da condição de agente, como já reconheceu a mais alta Corte no AgR RE 418.023-5 - RJ, Relator Ministro Eros Grau, sob a seguinte ementa:

Agravo Regimental no Recurso Extraordinário. Responsabilidade civil objetiva do Estado. Art. $37, \S 6^{\circ}$, da Constituição. Crime praticado por policial militar durante o período de folga, usando arma da corporação. Responsabilidade civil objetiva do Estado. Precedentes. Agravo regimental a que se nega provimento ${ }^{160}$.

\subsubsection{Terceiros}

Quanto ao vocábulo terceiros observa-se, desde logo, que o preceito constitucional refere-se a alguém estranho à Administração e ao particular que sofre o dano, seja ele pessoa física ou jurídica, e que não possui qualquer vínculo jurídico com o Estado, o que denota a consagração de uma responsabilidade no campo extracontratual, já que aquele que contrata com o Estado não é terceiro, mantendo vínculo jurídico com a Administração.

responsabilidade direta por eventuais danos causados a terceiros no desempenho de suas funções. 3 . Assentou, ainda, que o texto constitucional não restringiu a responsabilidade do Estado aos atos praticados pelos funcionários públicos como na Carta anterior, mas consignou o termo agente - gênero do qual é espécie o agente político - abarcando, assim, os atos praticados por todos os agentes públicos”. STF. AgR RE 518278 - GOIÁS Relator: Ministro Eros Grau. 2a Turma. Julgamento: 31/03/2009. DJe no 75 . Publicação 24/04/09.

Disponível

em: http://www.stf.jus.br/portal/jurisprudencia/listarJurisprudencia.asp?s1=responsabilidadeobjetivaestado\&base =baseAcordaos. Acesso em 10.08.09.

${ }^{158}$ ARAÚJO, Edmir Netto de. Curso de Direito Administrativo. 4. ed. São Paulo: Saraiva, 2009, pp. 255 e 838.

${ }^{159}$ DI PIETRO, Maria Sylvia Zanella. Curso de Direito Administrativo. 22. ed. São Paulo: Saraiva, 2009, p. 646.

${ }^{160}$ STF, AgR RE 418.023-5 - RJ. Relator: Ministro Eros Grau. $2^{\text {a }}$ Turma. Julgamento em: 09/09/08. DJe ${ }^{\circ}$ 197. Publicação 17/10/08. Disponível em: http://www.stf.jus.br/portal/inteiroTeor/obterInteiroTeor.asp?numero=418023\&classe=RE-AgR. Acesso em 10.08.09. 
Recentemente o STF reconheceu, inclusive, que os não-usuários dos serviços públicos também estão abrangidos pela figura do terceiro, modificando, assim, entendimento anterior já consagrado quanto à responsabilidade das pessoas jurídicas de direito privado prestadoras de serviços públicos em relação a terceiros não-usuários do serviço $^{161}$.

\subsubsection{Nexo causal}

Do teor disposto no artigo $37, \S 6^{\circ}$, da CF verifica-se, ainda, como requisito indispensável a configurar a responsabilidade, a necessidade de que exista um dano causado a terceiro. Tal se refere à necessidade de que a vítima demonstre o nexo de causalidade (relação de causa e efeito) entre o ato comissivo ou omissivo do Estado e o resultado danoso produzido para que possa ocorrer ressarcimento.

Somente cabe falar em responsabilidade estatal quando o autor da ação provar em juízo que o comportamento do agente é causa eficiente do dano, ou seja, necessariamente o prejuízo de que se queixa o particular tem que ser consequência da atividade ou omissão administrativa para fazer atuar o instituto.

Todavia, se resta claro que não há responsabilidade sem esse liame que liga a atuação estatal ao dano, há problema, contudo, para identificação dessa causa. Discute-se qual seria o motivo eficiente para revelar a responsabilidade, especialmente quando se está diante de uma pluralidade de fatos que podem interferir na causa.

Há várias teorias na busca da melhor explicação sobre a relação causal ${ }^{162}$. Importa destacar apenas duas delas, por serem as mais utilizadas pela jurisprudência pátria: a teoria da causalidade adequada e a teoria dos danos diretos e imediatos ou teoria da interrupção do nexo causal.

\footnotetext{
161 "O Supremo Tribunal Federal (STF) definiu que há responsabilidade civil objetiva (dever de indenizar danos causados independente de culpa) das empresas que prestam serviço público mesmo em relação a terceiros, ou seja, aos não-usuários. A maioria dos ministros negou provimento ao Recurso Extraordinário (RE) 591874 interposto pela empresa Viação São Francisco Ltda". In: Prestadoras de serviço público têm responsabilidade objetiva em relação a terceiros não-usuários. Notícias do STF de 26 de agosto de 2009. Disponível em http://www.stf.jus.br/portal/cms/verNoticiaDetalhe.asp?idConteudo=112429. Acesso em 18.09.09.

${ }^{162}$ Cite-se a teoria da equivalência das condições, teoria da causa próxima e da causa remota, teoria da causalidade eficiente, teoria negativa de Mayer, teoria da causalidade típica, teoria da causalidade adequada.
} 
A teoria da causalidade adequada leva em consideração as possibilidades e as probabilidades de certo resultado ocorrer. Parte de juízos hipotéticos para determinar qual a verdadeira causa adequada para a produção do dano. Todavia, embora adotada por alguns tribunais pátrios, recebe críticas da doutrina, que julga que a teoria padece de dificuldade em determinar o que efetivamente é ou não causa adequada, além de depender demasiadamente do arbítrio do julgador para ser aplicada em concreto.

Já a teoria dos danos diretos e imediatos é mais bem acolhida no ordenamento jurídico pátrio, sendo que o próprio Código Civil dispõe, no seu artigo 403, sobre a possibilidade de pleitear perdas e danos somente em face dos prejuízos efetivos e lucros cessantes por efeito direto e imediato da inexecução do devedor.

Por meio dessa teoria defende-se que nem todo fator que desemboca no evento danoso é necessariamente causa do dano, sendo necessário traçar um liame lógico-jurídico para verificar a causa necessária para o dano. Dentre os entendimentos que defluem da expressão direto e imediato, destaca-se aquele que a compreende como causa o evento mais necessário e determinante a proporcionar o resultado, ou seja, é o evento mais direto, ainda que não temporalmente próximo.

O Superior Tribunal Federal já teve oportunidade de enfrentar o assunto no RE 130.764, Primeira Turma, Relator Ministro Moreira Alves, julgado em 12/05/1992, DJ 07 de agosto de $1992^{163}$, e consagrou, ainda que de forma não muito precisa, a referida teoria quando do julgamento da ocorrência da responsabilidade do Estado por força de um dano decorrente de assalto por quadrilha de que fazia parte um preso foragido da prisão vários meses antes e que, mesmo diante do lapso temporal entre a fuga e o evento danoso, verificou-se que tal não teria ocorrido não fosse a omissão da autoridade pública na guarda do referido elemento.

\footnotetext{
${ }^{163}$ STF, Ementa: “(...) Em nosso sistema jurídico, como resulta do disposto no artigo 1.060 do Código Civil, a teoria adotada quanto ao nexo de causalidade e a teoria do dano direto e imediato, também denominada teoria da interrupção do nexo causal. Não obstante aquele dispositivo da codificação civil diga respeito a impropriamente denominada responsabilidade contratual, aplica-se ele também a responsabilidade extracontratual, inclusive a objetiva, até por ser aquela que, sem quaisquer considerações de ordem subjetiva, afasta os inconvenientes das outras duas teorias existentes: a da equivalência das condições e a da causalidade adequada. No caso, em face dos fatos tidos como certos pelo acórdão recorrido, e com base nos quais reconheceu ele o nexo de causalidade indispensável para o reconhecimento da responsabilidade objetiva constitucional, é inequívoco que o nexo de causalidade inexiste, e, portanto, não pode haver a incidência da responsabilidade prevista no artigo 107 da Emenda Constitucional n. 1/69, a que corresponde o parágrafo $6^{\circ}$ do artigo 37 da atual Constituição (...)". Disponível em: http://www.stf.jus.br/portal/inteiroTeor/obterInteiroTeor.asp?numero=130764\&classe=RE. Acesso em: 08.12 .09 .
} 
Utilizando-se dessa mesma teoria a Corte Máxima também reconheceu no RE 136.247-RJ, Segunda Turma, em julgamento de 07.03.2006, DJ 20 de abril de $2007^{164}$, a responsabilidade estatal pela omissão do Estado em fiscalizar o cumprimento do regime prisional por parte de um condenado, o que permitiu com que este praticasse crime de estupro contra menor de 12 anos de idade, justamente no período em que deveria estar recolhido à prisão. Aventou-se, no caso, nos votos dos Ministros Celso de Mello, Joaquim Barbosa e Ellen Gracie, tendo o Ministro Carlos Velloso, relator do caso, proferido voto divergente, a afirmação de que a omissão estatal foi causa direta do evento danoso, o que reiterou, enfim a caracterização da responsabilidade civil estatal.

\footnotetext{
${ }^{164}$ STF, Ementa: "Responsabilidade civil do Estado. Art. 37, § $6^{\circ}$ da Constituição Federal. Faute du service public caracterizada. Estupro cometido por presidiário, fugitivo contumaz, não submetido à regressão de regime prisional como manda a lei. Configuração do nexo de causalidade. Recurso Extraordinário desprovido. Impõe-se a responsabilização do Estado quando um condenado submetido a regime prisional aberto pratica, em sete ocasiões, falta grave de evasão, sem que as autoridades responsáveis pela execução da pena lhe apliquem a medida de regressão do regime prisional aplicável à espécie. Tal omissão do Estado constituiu, na espécie, o fator determinante que propiciou ao infrator a oportunidade para praticar o crime de estupro contra menor de 12 anos de idade, justamente no período em que deveria estar recolhido à prisão. Está configurado o nexo de causalidade, uma vez que se a lei de execução penal tivesse sido corretamente aplicada, o condenado dificilmente teria continuado a cumprir a pena nas mesmas condições (regime aberto), e, por conseguinte, não teria tido a oportunidade de evadir-se pela oitava vez e cometer o bárbaro crime de estupro. Recurso extraordinário desprovido". Disponível em: http://www.stf.jus.br/portal/inteiroTeor/obterInteiroTeor.asp?numero=136247\&classe=RE. Acesso em: 08.12 .09 .
} 
SEGUNDA PARTE:

A RESPONSABILIDADE CIVIL DO ESTADO LEGISLADOR 


\section{O ESTADO LEGISLADOR}

\subsection{A FUNÇÃO LEGISLATIVA}

Antes de adentrar propriamente no tema da responsabilidade civil do Estado Legislador, há que se ter uma noção mais apropriada e específica do objeto que pode ensejar a atuação do instituto da responsabilidade: a função legislativa. O tema predica dar um passo atrás para se analisar as modificações pelas quais passou e ainda passa o próprio conceito de lei e do modo como se estrutura e se organiza o Estado Legislador atualmente.

Há que se considerar que o Estado Legislador da época liberal não é o mesmo do momento hodierno. $\mathrm{O}$ mesmo se pode dizer da lei. Características do ato legislativo, como a consideração de ato dotado de generalidade e abstração, o seu caráter inviolável, a idéia formal de ato proveniente do Poder Legislativo, não se encaixam mais tão bem com o tipo de Estado que emerge no presente século.

Por isso, faz-se necessário o estudo, ainda que de forma breve, das construções jurídicas desenvolvidas ao longo da História, na tentativa de explicar o conceito de lei, para que se possa melhor compreender o desempenho da função legislativa no ordenamento jurídico pátrio.

\subsubsection{Evolução do conceito de lei}

Ao longo da História, diversos foram os ensaios, as construções jurídicas desenvolvidas para formulação de um conceito de lei, não se podendo dizer, contudo, que se trate de construções estanques, em que não se misturam os aspectos de uma em outra ${ }^{165}$. O que será feito adiante é, sem dúvida, uma simplificação dessas visões, apontando suas principais características, de modo a propiciar tanto a compreensão dessas diversas formulações, quanto o modo como ocorre o desempenho da função legislativa no ordenamento pátrio.

${ }^{165}$ Cf. MARTín, Carlos de Cabo. Sobre el concepto de ley. Madrid: Trotta, 2000, p. 23. 
Na Idade Média, vigorava a concepção de que a lei era não mais do que uma forma de autenticação do costume. Não havia a criação de uma lei, sendo que ela era apenas o registro feito pelo Parlamento de uma prática, um comportamento já vigente na comunidade, que o reconhecia como justo. Bem por isso a lei assumia, nessa época, a conotação de justiça, ou seja, toda lei era fundamentalmente justa e por isso deveria ser obedecida.

Essa concepção modificou-se apenas com o surgimento do Estado de Direito, mais especificamente no período após o triunfo da Revolução Francesa. Nessa época, os postulados de segurança e unidade jurídica, necessários ao desenvolvimento da autonomia da vontade e da livre circulação de mercadorias, associavam a produção do direito com o Estado. Daí que, adotando a teoria da separação de poderes elaborada por Montesquieu, as Constituições do século XVIII, especialmente a americana e a francesa ${ }^{166}$, atribuíam o processo legislativo como função precípua do Poder Legislativo, órgão onde se encontravam os representantes da vontade do povo.

Dado o caráter representativo do Parlamento, percebido como órgão de representação de toda a nação e não apenas de cada cidadão que elegeu o seu representante, este era o único capaz de produzir a lei e sintetizar a vontade geral, ou seja, era o único órgão com legitimidade para produzir um ato legislativo que limitasse a liberdade dos cidadãos. Diante disso a lei, independentemente do conteúdo que apresentasse, passou a ser compreendida como o ato pelo qual adquirem forma as decisões do Parlamento. Trata-se, portanto, de uma concepção formal de lei: a lei era definida pelo Parlamento e, posteriormente, também o definia (o Parlamento era o órgão que criava a lei).

Em razão da legitimidade democrática do órgão de que provém, sintetizador da vontade geral, atribui-se à lei um caráter de inviolabilidade, quase sagrado, não se concebendo, por isso, qualquer possibilidade de controle desta, nem muito menos que ela pudesse causar qualquer prejuízo injusto.

Essa concepção, entretanto, passa a sofrer críticas quando, através da consagração do sufrágio universal, o Parlamento converte-se no centro de debate político e passa, então, a sofrer com a crise de representação. O sufrágio universal, ao permitir o desenvolvimento

${ }^{166}$ Cf. FERREIRA FILHO, Manoel Gonçalves. Do processo legislativo. 6. ed. São Paulo: Saraiva, 2007, p. 63. 
dos partidos políticos e de grupos de pressão no seio do parlamento, levou ao reconhecimento da lei como fruto de um interesse prevalente, não mais se caracterizando como a síntese da vontade geral, o que conduziu ao seu desprestígio e, ainda, como se vê hoje, à sua constante desconsideração.

Outro ensaio sobre o conceito de lei, desta vez uma concepção que a toma em seu sentido material, desenvolveu-se no clima histórico da época da Restauração na França, entre a queda do Império francês (1814) e a Revolução de 1830, marcada pelo retorno da França à soberania monárquica. Na Alemanha, quando também apareceram as primeiras monarquias constitucionais (Constituições que surgem a partir de 1814), nas quais, igualmente, articula-se o princípio monárquico com o princípio representativo, também despontou a construção da lei de acordo com o conteúdo que esta apresenta.

Por meio dessa construção identifica-se a lei como norma jurídica (regra de direito) e norma jurídica é unicamente aquela manifestação da vontade estatal (ato votado pelo Parlamento), cujo conteúdo tem por finalidade a regulação de situações jurídicas, nomeadamente daquelas situações que interferem na liberdade e na propriedade dos cidadãos. Os demais atos normativos que afetam o funcionamento do Estado não são regras de direito, mas sim normas administrativas.

Caracteriza-se, assim, a teoria dualista, pois para ser ato legislativo não apenas deve ter forma de lei (ato votado pelo Parlamento), mas também precisa ter conteúdo de lei (interferir na esfera de liberdade e propriedade dos cidadãos) ${ }^{167}$.

Tal distinção, contudo, do ponto de vista jurídico, carecia de precisão, em virtude da dificuldade de realizar uma construção teórica uniforme do conceito de regra de direito. Daí que essa dificuldade, aliada também a fatores históricos, não permitiu que tal concepção lograsse estabelecer-se como uma teorização adequada do conceito de lei.

Outra tentativa de identificar uma lei decorre da construção que a reconhece como $\mathrm{o}$ ato dotado de generalidade e abstração. Generalidade seria aquela qualidade em virtude da qual os destinatários do ato estão genericamente determinados; a abstração refere-se às condutas a que se aplica: no ato legislativo as previsões fáticas as quais se aplica devem estar abstratamente consideradas.

${ }^{167}$ CLÈVE, Clèmerson Merlin. A lei no Estado contemporâneo. Cadernos de Direito Constitucional e Ciência Política, Revista dos Tribunais, São Paulo, n.21, pp. 124-138, out./dez. 1997, p. 126. 
Essa concepção, elaborada já em tempos pré-estatais ${ }^{168}$, destaca-se no momento limiar do constitucionalismo, que passa a incorporá-la aos textos constitucionais. Concebese, na França, principalmente pela doutrina de Duguit, a idéia de lei como ato-regra: o ato regra é um ato estatal que formula uma regra de direito objetivo (incluindo-se as que regulam os órgãos ou instituições dirigidas a assegurar o cumprimento dessas regras) que, por sua vez, caracteriza-se por sua imperatividade e generalidade compreensiva de sua abstração ${ }^{169}$. Na Alemanha também se desenvolve tal entendimento, sob a argumentação de que somente a lei (geral) pode servir aos fins do Estado de Direito, que busca participação e distribuição.

Contudo, nos fins do século XIX, quando se constatou a insuficiência do modelo liberal para garantia dos direitos individuais, cobrou-se do Estado uma feição intervencionista, o que resultou no crescimento do aparelho administrativo e no fortalecimento do Poder Executivo, ante as novas funções que o Estado devia então desempenhar.

Essas novas competências assumidas demandaram a atribuição da função normativa ao Poder Executivo que poderia, em determinados sistemas jurídicos, baixar regulamentos, inclusive autônomos, participar do processo de elaboração das leis ou expedir atos normativos com força de lei.

Disso resulta, por certo, a desvinculação da concepção de ato legislativo como aquele proveniente unicamente do parlamento, já que também o Executivo passou a ter competência para expedir atos de caráter normativo, de acordo com a regulamentação constitucional estabelecida.

Há, neste momento, uma reconfiguração do entendimento acerca do princípio da legalidade, passando-se a compreender que o conceito de lei abrange diferentes normas de direito, oriundas de fontes diversas (não apenas os atos normativos editados pelo Poder Legislativo, mas também os atos normativos que então poderiam ser editados pelo Poder Executivo).

\footnotetext{
${ }^{168}$ Cf. MARTíN, Carlos de Cabo. Sobre el concepto de ley. Madrid: Trotta, 2000, p. 47.

${ }^{169}$ DUGUIT, Léon. Traité de Droit Constitutionnel. T. II. Paris: Ancienne Librairie Fontemoing, 1923, p. 144 et seq.
} 
O conteúdo da lei também se modificou, pois ela passa a prever a solução para circunstâncias concretas, o que traz por conseqüência a perda da sua característica de generalidade. O Estado intervencionista precisa alcançar determinados objetivos e, deste modo, o ato legislativo passa a condensar essa conjuntura, bem por isso produzem-se as denominadas leis-objetivo ou leis de efeitos concretos, as quais, concomitantemente, possuem um caráter transitório, na medida em que são criadas apenas para solução de uma determinada situação.

Carlos de Cabo Martín adverte que dois pressupostos modificam a teorização da generalidade da lei, que é própria do Estado liberal de Direito. Um é o pressuposto de natureza sócio-econômica, in verbis:

Um desses pressupostos é o de natureza sócio-econômica. Trata-se, como se vinha indicando, de uma parte, da correspondência entre lei geral e mercado de livre concorrência, uma vez que a generalidade garantia que a concorrência se desenvolvesse em um quadro de igualdade entre os sujeitos competidores; de outra parte, a existência de uma burguesia relativamente homogênea que dominava os Parlamentos permitia chegar com certa facilidade a consensos que se expressavam como 'interesse geral', segundo a habitual transformação ideológica burguesa do interesse próprio em interesse geral; e finalmente, dada a escassa intensidade das relações Estado-sociedade, estas também eram demarcadas por um escasso número de leis. Tudo isso muda com o capitalismo monopolístico, ao desaparecer a livre concorrência, romper-se a homogeneidade e coerência da classe dominante, e, consequentemente, sua representação parlamentar, e aparecer uma nova articulação Estadosociedade, com um sistema de inter-relações quantitativas e qualitativamente distintas (ou seja, freqüentes e concretas) que já não se ajustam às exigências usuais de lei ${ }^{170}$. (tradução livre)

O outro pressuposto é de natureza jurídico-constitucional e consiste:

(...) na configuração definitiva das constituições como normativas, o que supõe desde logo a incorporação de um ponto de vista formal da garantia técnica do ordenamento e de um ponto de vista material do valor da

\footnotetext{
170 "Uno de esos supuestos es de naturaleza socio-económica. Se trata, como se había venido indicando, por una parte, de la correspondencia entre ley general y mercado de libre competencia, en cuanto la generalidad garantizada que la competencia se desarrollara en un marco de igualdad entre los sujetos que competían; por otra, la existencia de una burguesía relativamente homogénea que dominaba los Parlamentos permitía llegar con cierta facilidad a confluencias que se expresaban como 'interés general' según la habitual transmutación ideológica burguesa del interés proprio en general; y finalmente, dada la escasa intensidad de las relaciones Estado-sociedad, cabían en un también escaso número de leyes como marco - general - de las mismas. Todo ello cambia con el capitalismo monopolístico al desaparecer la libre competencia, romperse la homogeneidad $\mathrm{u}$ coherencia de la clase dominante, y por tanto su representación parlamentaria, y aparecer una nueva articulación Estado-sociedad con un sistema de interrelaciones cuantitativa y cualitativamente distintas (es decir, frecuentes y concretas) que ya no se ajustan a las exigencias de la ley como general". MARTíN, Carlos de Cabo. Sobre el concepto de ley. Madrid: Trotta, 2000, p.53.
} 
igualdade, de maneira que se encobrem as funções que a lei usualmente desempenhava ${ }^{171}$. (tradução livre)

Assim, conclui o autor:

Ambas as modificações se complementam: a sócio-econômica exige a quebra da generalidade, a jurídico-constitucional a possibilita. Daí que efetivamente passe a ser dominante a postura que nega à lei o caráter de generalidade, por se entender que isso é inútil nos sistemas em que está assegurada a supremacia da Constituição, já que além de assumir o papel que a lei costumava desempenhar, abrange, ainda, a característica de obrigatoriedade e limite para o legislador. Daí também - obedecendo àquelas exigências - que passa a ser admissível, a partir dessas considerações, a aparição de leis especiais ${ }^{172}$. (tradução livre).

Compreende-se que a quebra da concepção da lei como ato geral e abstrato relaciona-se ao aumento das funções que passam a ser desempenhadas pelo Estado por ocasião do surgimento do Welfare State. O aumento da intervenção estatal, traduzida pelo incremento de seus deveres para com os administrados, modifica a atuação legislativa, pois demanda a elaboração de um número de leis cada vez maior, com maior especificidade e de acordo com os novos padrões de complexidade existentes na sociedade.

Daí resultar na modificação da concepção clássica da lei, considerada ato geral e abstrato, para compreendê-la como um instrumento de conformação social, uma norma que precisa implementar uma política pública e, para realizá-la, pode direcionar-se a um determinado indivíduo ou grupo deles. Modificam-se, portanto, as características da lei, que passa a compreender não só os atos gerais e abstratos, mas sim leis-objetivo ou leismedida, destinadas a solucionar casos particulares e concretos.

Diante de todas as concepções elaboradas, conclui Carlos de Cabo Martín ${ }^{173}$ que, atualmente, não há um conceito unitário de lei, já que isto é impossível em face da aparição no Direito Positivo de diferentes tipos de lei e, por sua vez, pela ruptura da coesão dos seus elementos característicos.

\footnotetext{
171 “(...)en la configuración definitiva de las constituciones como normativas, lo que supone incorporar desde un punto de vista formal la garantía técnica del ordenamiento y desde un punto de vista material el valor de la igualdad, de manera que se cubren las funciones que desempeñaba la ley en cuanto general.”. MARTín, Carlos de Cabo. Sobre el concepto de ley. Madrid: Trotta, 2000, p.53.

172 "Ambos cambios se complementan: el socio-económico exige la quiebra de la generalidad; el jurídicoconstitucional la posibilita. De ahí que efectivamente pase a ser dominante la postura que niega a la ley el carácter de la generalidad por entenderse que es inútil en los sistemas en los que está asegurada la supremacía de la Constitución y, por tanto, su asunción del papel que hacía la ley como general, incluida la de la obligatoriedad y limite para el legislador. De ahí también - obedeciendo a aquellas exigencias - la aparición de las leyes especiales que se admiten a partir de esas consideraciones". Ibidem, p.53.

${ }^{173}$ Cf. MARTín, Carlos de Cabo. Sobre el concepto de ley. Madrid: Trotta, 2000, p. 97.
} 
No mesmo sentido é a síntese de Clèmerson Merlin Clève que, escrevendo sobre o conceito de lei vigente nos tempos hodiernos, infere:

Não se concilia com a idéia de lei com conteúdo porque a lei contemporânea não tem nenhum compromisso prévio com determinado conteúdo e também não se concilia com a idéia de lei definida a partir de sua estrutura - generalidade e abstração - porque o Estado agora utiliza a lei não apenas como mecanismo de arbitragem, mas também para alcançar determinados objetivos concretos. Hoje, bem por isso, a lei votada pelo Parlamento é, muitas vezes, uma lei transitória, criada para resolver determinada questão respeitante apenas a uma singular conjuntura. Uma lei-objetivo à medida que dirigida à solução de uma questão concreta, atingindo determinados grupos ${ }^{174}$.

Fala-se, assim, na crise do próprio conceito de lei, que não pode mais ser concebida através de uma noção unitária e universal, dada a ruptura da coesão dos elementos característicos da lei que foram formulados ao longo da História ${ }^{175}$.

Daí a necessidade de compreender o fenômeno legislativo de acordo com o disposto no quadro constitucional de determinado ordenamento jurídico, haja vista não ser possível falar-se num conceito universal de lei, nem compreender também que o processo legislativo está adstrito a ser exercido por um dos poderes estatais.

Vale ressaltar, ainda, que alguns aspectos que conduzem à inviabilidade da elaboração de um conceito de lei de modo unitário e universal também resultam no sentido do reconhecimento da inadequação do ato legislativo proveniente do Parlamento para atender aos anseios de uma sociedade cada vez mais conflitiva e de interesses antinômicos.

Os constantes avanços tecnológicos, a exigir medidas normativas cada vez mais técnicas, bem como acompanhantes do mesmo ritmo das modificações, conduzem não só a uma intensa multiplicação legislativa, como também levam ao reconhecimento do caráter transitório do ato legislativo, fatores que, aliados à falta de planejamento e estudo na sua elaboração - especialmente porque os interesses particulares, no modelo parlamentar clássico, ainda adotado no ordenamento pátrio, por exemplo, dirigem a formação do ato levam a sua inadequação à imprestabilidade para a solução dos problemas hoje vigentes na sociedade.

${ }^{174}$ CLÈVE, Clèmerson Merlin. A lei no Estado contemporâneo. Cadernos de Direito Constitucional e Ciência Política, Revista dos Tribunais, São Paulo, n.21, pp. 124-138, out./dez. 1997, p. 128.

${ }^{175}$ Ibidem, p. 97. 
Sua abundância e efemeridade resultam no constante desprezo dos atos legislativos por parte dos cidadãos, que, evidentemente, identificam suas imperfeições e, em consequiência, ajuízam medidas questionando a sua legitimidade em face da Constituição.

\subsubsection{O Estado Legislador no Brasil}

A Constituição Federal de 1988 definiu, no artigo 59 e incisos, que o processo legislativo no ordenamento jurídico brasileiro compreende a elaboração de emendas à Constituição, leis complementares, leis ordinárias, leis delegadas, medidas provisórias, decretos legislativos e resoluções.

Observa-se que o dispositivo listou não só atos que são provenientes do Poder Legislativo, mas também os que são oriundos do Poder Executivo, os quais, na verdade, se resumem a um apenas: a medida provisória ${ }^{176}$. Formalmente, portanto, tem-se que o Estado Legislador, no Brasil, embora prioritariamente se confunda com o Poder Legislativo - a Constituição conferiu a função legislativa de modo preferencial ao Poder Legislativo abrange também o Poder Executivo, órgão que, através da edição de medida provisória que não é lei, mas tem força de lei (art. 62, caput da CF) - pode legislar $^{177}$.

Vislumbra-se, diante da expressa previsão do artigo 59, que vigora no direito constitucional brasileiro o princípio da tipicidade dos atos legislativos, ou seja, consideram-se atos legislativos apenas aqueles assim dispostos no citado dispositivo, que não estão necessariamente vinculados entre si por serem originários de um mesmo órgão, nem, como se verá, por deterem certo conteúdo ou estrutura - generalidade e abstração embora, para serem válidos, todos devam obedecer aos valores constitucionais e também se submeter às regras relativas ao processo legislativo. Daí que, como conclui Clèmerson Merlin Clève ${ }^{178}$, dentro do quadro constitucional brasileiro a lei se define por seu regime

\footnotetext{
${ }^{176}$ José Afonso da Silva aduz que as medidas provisórias não deveriam figurar no rol do artigo 59, uma vez que não são objeto de processo legislativo, sendo simplesmente editadas pelo Presidente da República. Cf. SILVA, José Afonso da. Curso de Direito Constitucional Positivo. 32. ed. São Paulo: Malheiros, 2009, p. 524.

${ }^{177}$ Cf. CLÈVE, Clèmerson Merlin. A lei no Estado contemporâneo. Cadernos de Direito Constitucional e Ciência Política, Revista dos Tribunais, São Paulo, n.21, pp. 124-138, out./dez. 1997, p. 131.

${ }^{178}$ Cf. CLÈVE, Clèmerson Merlin. A lei no Estado contemporâneo. Cadernos de Direito Constitucional e Ciência Política, Revista dos Tribunais, São Paulo, n.21, pp. 124-138, out./dez. 1997, p. 129.
} 
jurídico, ou seja, a lei consubstancia uma decisão veiculada por um ato legislativo previsto na Lei Fundamental da República, especificamente no artigo $59^{179}$.

Cabe destacar que a Constituição Federal assegura aos demais Poderes a participação no processo legislativo, ora, por exemplo, através da possibilidade de veto acaso oposta pelo Poder Executivo à lei, ora através da iniciativa das leis, tal como disposto no artigo 96, II, "b”, da Carta Maior, o qual preconiza competir privativamente ao Supremo Tribunal Federal, aos Tribunais Superiores e aos Tribunais de Justiça (órgãos do Poder Judiciário) propor ao Poder Legislativo a criação e a extinção de cargos e a remuneração dos seus serviços auxiliares e dos juízos que lhe forem vinculados, bem como a fixação do subsídio de seus membros e dos juízes, inclusive dos tribunais inferiores, onde houver.

Essa possibilidade de cooperação, que realiza a independência entre os Poderes, não retira, entretanto, a característica de que a ação de legislar é primordialmente exercida pelo Poder Legislativo, cabendo a este essencialmente elaborar, discutir e votar os atos delineados pelo artigo 59 do Texto Fundamental.

Há que se observar que a Constituição não adotou como critério para reunir os atos elencados no citado dispositivo a característica de que essas normas introduzam inovação originária na ordem jurídica, uma vez que outros veículos normativos, previstos na própria Carta Fundamental, também podem produzir tal inovação.

Confiram-se os exemplos citados por Maurício Zockun ${ }^{180}$, como os Convênios (artigos 155, §2 $2^{\circ}$ XII, “g” da CF e artigo 34, $\S 8^{\circ}$ do ADCT), as Instruções (art. $92, \S 4^{\circ}$ do ADCT), certas espécies de Resoluções, como as editadas pelo Conselho Nacional de Justiça (art. $5^{\circ}, \S 2^{\circ}$, do ADCT) ${ }^{181}$, que também são capazes de introduzir inauguralmente

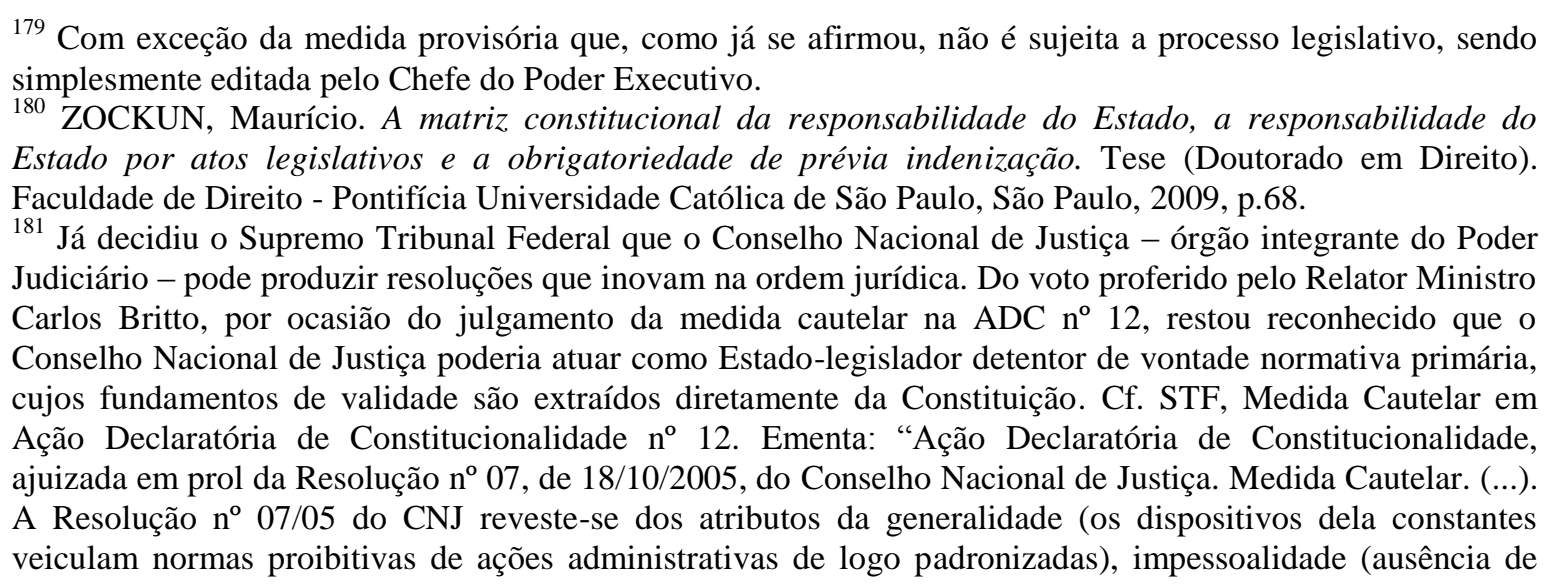


novos encargos na ordem jurídica. Poderia se destacar, ainda, os regimentos internos elaborados pelos tribunais, que também são normas através das quais se produz uma inovação originária no ordenamento.

Nesse sentido, não se pode afirmar, sem cair em certa contradição, que os atos legislativos, no contexto da CF de 1988, definem-se pela sua característica de inovação na ordem jurídica, posto que outros atos normativos também o fazem, conforme permitido pelo próprio Texto Fundamental. Não é, portanto, tal traço que diferencia os atos legislativos dos demais atos normativos editados pelo Estado.

Todavia, não sendo possível compreender como ato legislativo aquele proveniente do Poder Legislativo, nem aquele que inova originariamente na ordem jurídica, pondera-se, com Manoel Gonçalves Ferreira Filho ${ }^{182}$, que o artigo 59 da Constituição inclui dentre os atos oriundos do processo legislativo medidas que não possuem caráter geral e abstrato, tais como os decretos legislativos e as resoluções. Os decretos legislativos, por destinaremse a reger matéria exclusiva do Congresso Nacional, arroladas no artigo 49 da CF, não possuem a normatividade abstrata a possibilitar a definição da lei como norma geral e abstrata. Já as resoluções parlamentares, também destinadas à definição de assuntos políticos e administrativos internos do próprio Congresso, estão reservadas para a solução de questões individuais.

Somado a isso há que se considerar, como já afirmado, que a existência de um Estado, tal como o consagrado no ordenamento pátrio, dedicado a estimular, guiar e controlar a atividade dos grupos e dos indivíduos para a consecução de certas metas, levao, necessariamente, em determinadas circunstâncias, a editar leis, tais como as formalmente previstas no artigo 59, que não possuem as características de generalidade e abstração, posto que visam alterar uma situação concreta, promover determinado setor da atividade econômica através de estímulos, realizar o planejamento urbano de uma

indicação nominal ou patronímica de quem quer que seja) e abstratividade (trata-se de um modelo normativo com âmbito temporal de vigência em aberto, pois claramente vocacionado para renovar de forma contínua o liame que prende suas hipóteses de incidência aos respectivos mandamentos). A Resolução $n^{\circ} 07 / 05$ se dota, ainda, de caráter normativo primário , dado que arranca diretamente do $\S 4^{\circ}$ do art. 103-B da Carta-cidadã e tem como finalidade debulhar os próprios conteúdos lógicos dos princípios constitucionais de centrada regência de toda a atividade administrativa do Estado, especialmente o da impessoalidade, o da eficiência, o da igualdade e o da moralidade.". (Grifo nosso). Relator: Ministro Carlos Britto. Tribunal Pleno. Julgado em 16/02/06. DJ 01/09/06. Disponível em: http://www.stf.jus.br/portal/inteiroTeor/obterInteiroTeor.asp?numero=12\&classe=ADC-MC. Acesso em: 17/12/09.

${ }^{182}$ FERREIRA FILHO, Manoel Gonçalves. Do processo legislativo. 6. ed. São Paulo: Saraiva, 2007, p. 199. 
determinada cidade (v. artigo 182 e seguintes da Constituição). Daí que esta ordem jurídica, no fluxo das idéias que pugnam por uma atitude estatal interventiva, admite a existência de leis-objetivo, destinadas a resolver uma situação concreta. Podem, por isso, ser editadas leis, de forma legítima, pelo Poder Legislativo, que visam à proteção de uma determinada área verde; que, ao definirem o zoneamento urbano, estabelecem um tratamento concreto para um caso individual, interferindo no direito de propriedade do particular, etc.

Por isso mesmo também não é possível concluir que este ordenamento compreende como leis apenas as normas que possuem caráter geral e abstrato, pois tal seria desconsiderar uma infinidade de normas que, a despeito de revestirem-se da forma disposta num dos incisos do artigo 59, apresentam características individuais e concretas e que são necessárias à consecução de finalidades constitucionalmente válidas.

Para fins de responsabilidade, contudo, se verá que tais atos legislativos são considerados pela doutrina e jurisprudência pátria como equiparáveis aos atos administrativos, o que, como se explicará adiante, é admissível, se facilitar a caracterização da responsabilidade estatal em benefício do particular.

Pelo exposto, firma-se que o Estado Legislador, no direito brasileiro, qualifica-se através de um critério formal, de modo que os atos legislativos são o resultado, conforme delimitado no artigo 59 da CF, do processo legislativo.

Para fins de responsabilização estatal por atos legislativos, contudo, é comum verificar-se tanto na doutrina pátria quanto na jurisprudência uma concepção de Estado Legislador que não parte de tal compreensão, mas que identifica o ato legislativo como aquele que inova originariamente na ordem jurídica - ato normativo primário - com características de generalidade e abstração, provenientes de um corpo de representantes políticos. Leva-se em consideração o ato legislativo típico, que é aquele concebido no período do Estado liberal, cujas idéias já foram explicadas anteriormente.

Com base nisso, afasta-se a admissão da responsabilidade civil do Estado Legislador, já que essa retomada dos conceitos ditados pela teoria constitucional dos séculos XVIII, XIX e início do XX resulta na noção de supremacia da lei, sua incontrastabilidade e, conseqüentemente, na concepção de que lhe seja impossível gerar qualquer prejuízo. 
Reforça-se apenas que tais conceitos de ato legislativo não mais sobrevivem nos dias hodiernos, de modo que esses argumentos não encontram ressonância, tendo em conta, especificamente, a delimitação de ato legislativo adotada no ordenamento pátrio e o modelo de Estado desenhado pela Constituição. Cada um desses argumentos será estudado, ainda, de modo específico com relação à influência no tema da responsabilidade civil do Estado, no item que se segue neste trabalho.

Oportuno observar, por fim, que é comum a aplicação desses mesmos princípios e argumentos da responsabilidade civil do Estado Legislador para a solução de situações em que há um prejuízo causado ao particular em função do desempenho da função normativa pelo Estado, na qual não há, não obstante, a produção de um ato descrito no artigo 59 do Texto Maior.

Identificam-se, por exemplo, como situações de responsabilidade civil do Estado Legislador, quando o Poder Executivo, ao exercer o seu poder normativo, expede regulamentos com caráter geral e abstrato, equiparando o referido ato ao conceito material de lei historicamente desenvolvido.

Não só a generalidade e a abstração levam a aplicação dos mesmos princípios da responsabilidade do Estado Legislador a atos que não se enquadram formalmente na configuração de ato legislativo. Explica José Cretella Júnior ${ }^{183}$ que o tipo de regulamento existente no direito brasileiro também induz a um tratamento conjunto da responsabilidade em decorrência da lei e do regulamento, in verbis:

Regulamento não é lei. É ato administrativo geral, destinado a facilitar a aplicação da lei, devendo ser secundum legem e, jamais, praeter legem ou contra legem. Logo, forma um todo único indissociável, um conjunto com a lei, porque no Brasil não temos regulamento autônomo como em outros países.

Por esses motivos, a generalidade da doutrina assimila o regulamento à lei e unifica a responsabilidade legal e a responsabilidade regulamentar, tratando-as conjuntamente. (grifos do autor)

Todavia, como observa o referido autor, embora a lei e o regulamento possam apresentar inúmeros pontos de contato, não se pode confundir o desempenho da função legislativa, cujo resultado final é a lei, elaborada por todo um colegiado, com o exercício da função regulamentar, que se concretiza no decreto, editado pelo Chefe do Poder Executivo. Daí que, não se identificando o exercício da função legislativa de maneira

${ }^{183}$ CRETELLA JÚNIOR, José. Responsabilidade civil do Estado Legislador. In: CAHALI, Yussef Said (coord.). Responsabilidade civil: doutrina e jurisprudência. São Paulo: Saraiva, 1984, pp. 174 e 185. 
completa com o exercício do poder regulamentar, estes se regem, em vários casos, por princípios diferentes $^{184}$.

De modo geral, no entanto, em relação especificamente ao tema da responsabilidade civil do Estado, há que se levar em consideração que, normalmente, enfrenta-se o problema da responsabilidade do Estado Legislador examinando-se as características materiais do ato, motivo pelo qual se pode dizer que, sob esse aspecto material, quando o ato regulamentar guarda as características que classicamente se atribuem à lei (generalidade e abstração), seria possível a aplicação dos mesmos princípios ou argumentos que foram desenvolvidos para firmar a responsabilidade do Estado Legislador para a hipótese, o que não significa, entretanto, equiparar a lei ao ato regulamentar ou, ainda, responsabilizar o Estado Legislador, pois aquele que responderá pelos prejuízos, em eventual ação de regresso, no caso do regulamento, será o agente que integra os quadros do Poder Executivo, desde que reste comprovada a sua culpa ou dolo na elaboração da norma.

No entanto, acolhe-se aqui a posição de José Cretella Júnior, por se compreender que as especificidades de cada ato, inclusive no tocante ao seu processo de elaboração, levarão a argumentações diversas em relação ao tema da responsabilidade civil do Estado. Não se terá, por exemplo, as mesmas circunstâncias para tratar-se da ação de regresso na comparação entre um dano proveniente de um regulamento e de uma lei, já que os respectivos processos de elaboração são diversos (os diferentes procedimentos para elaboração do ato legislativo levariam a também diferentes conclusões acerca da culpa do agente público). Também não se utiliza argumentos relativos, por exemplo, a existência de imunidades, tais como as conferidas aos parlamentares pelo artigo 53 da Constituição, para tratar de danos decorrentes de atos normativos do Executivo.

Como bem observa Maurício Zockun ${ }^{185}$, a responsabilidade civil do Estado por atos legislativos pode tanto decorrer do produto legislado como o processo legislativo. Daí, evidentemente, não se poder equiparar, nem para fins de responsabilização, o ato

\footnotetext{
${ }^{184}$ CRETELLA JÚNIOR, José. Responsabilidade civil do Estado Legislador. In: CAHALI, Yussef Said (coord.). Responsabilidade civil: doutrina e jurisprudência. São Paulo: Saraiva, 1984, p. 185.

185 ZOCKUN, Maurício. A matriz constitucional da responsabilidade do Estado, a responsabilidade do Estado por atos legislativos e a obrigatoriedade de prévia indenização. Tese (Doutorado em Direito). Faculdade de Direito - Pontifícia Universidade Católica de São Paulo, São Paulo, 2009, p. 76.
} 
regulamentar danoso à lei danosa, uma vez que tais atos possuem processos de elaboração diferentes.

Dadas todas essas peculiaridades, não se elegeu no presente trabalho, como foco de análise, todos os atos legislativos consagrados no artigo 59 da Constituição Federal, nem é o intuito ater-se sobre o estudo dos atos que podem ser concebidos como contendo conteúdo material de lei. O objetivo é bem mais modesto e restrito: a análise dos atos legislativos, tal como definidos no artigo 59 da CF, provenientes do Poder Legislativo. Serão analisados os atos normativos especificamente provenientes do Poder Legislativo, de vez que uma tentativa abrangente de incluir toda manifestação legislativa ou todas as manifestações normativas que apresentam os mesmos caracteres do conceito de ato legislativo típico levaria a um estudo amplo, porém superficial, podendo inclusive desbordar em omissões de importantes características que interfeririam no tema da responsabilidade civil do Estado. 


\section{A RESPONSABILIDADE CIVIL DO ESTADO LEGISLADOR}

A responsabilidade do Estado em decorrência da edição - ou omissão - de atos legislativos foi a que por último surgiu na escala da evolução do instituto da responsabilidade estatal. Várias barreiras se apresentaram e ainda se apresentam à aceitação da responsabilidade do Estado Legislador, sendo certo que por muito tempo prevaleceu, tanto na doutrina quanto na jurisprudência, a tese da total irresponsabilidade do Estado em decorrência de sua atuação legislativa.

Léon Duguit foi um dos primeiros autores a afastar a tese da irresponsabilidade do Estado Legislador, na medida em que, ao considerar que o Estado atua como segurador de todo o risco resultante de sua atividade em geral, este seguro também cobre o risco que resulta da aplicação de uma lei. Daí considerar-se responsável o Estado pelas consequências de seus atos legislativos ${ }^{186}$.

O leading case que marca a admissão da responsabilidade do Estado por ato legislativo foi o aresto La Fleurette, proferido pelo Conselho de Estado francês em 1938, cuja decisão determinou que o Estado reparasse os prejuízos pela edição de ato legislativo de 29 de julho de 1934. Essa lei, em seu artigo $1^{\text {o }}$, determinava a interdição da fabricação, exposição, colocação à venda, importação, exportação ou transporte de qualquer produto destinado ao mesmo uso que as natas que não proviessem exclusivamente do leite. $\mathrm{O}$ ato visava, enfim, a proteção da indústria leiteira. O caso é que a referida lei, ao estabelecer tal proibição, diretamente interditou a fabricação de grandine, um creme sucedâneo de natas, que era produzido pela sociedade anônima La Fleurette. Essa empresa havia construído uma usina em Colombes, cuja produção anual era da ordem de 200.000 litros de grandine $^{187}$.

Analisando essa interdição legal, o Conselho de Estado entendeu que esta não atentava à saúde pública e que nada, nem no texto da lei, nem nos trabalhos preparatórios, nem no conjunto das circunstâncias do caso, permitia concluir que o legislador pretendera impor ao interessado uma carga que não lhe incumbiria normalmente, de modo que, criada

${ }^{186}$ DUGUIT, Léon. Traité de droit constitutionnel. t. 3. 3. ed. Paris : Ancienne Librarie Fontemoing \& Cie, 1930 , p. 554.

${ }^{187}$ MOTA, Maurício Jorge Pereira da. Responsabilidade civil do Estado legislador. Rio de Janeiro: Lumen Juris, 1999, p. 196. 
num interesse geral, devia ser suportada pela coletividade e por isso condenou o Estado a reparar os prejuízos.

Posteriormente a essa decisão, outras poucas foram proferidas pelo Conselho de Estado francês reconhecendo a responsabilidade civil do Estado Legislador: o aresto Cacheteux et Desmond, de 21 de janeiro de 1944, o aresto Bovero, de 25 de fevereiro de 1963, e o aresto Compagnie d'aménagément et de promotion imobilière (Capri), de 1 de novembro de $1981^{188}$.

No entanto, o desenvolvimento do tema da responsabilidade civil do Estado permite dizer, hoje, com maior tranquilidade, que os países que efetuam o controle de constitucionalidade das leis demonstram certa tendência em admitir a responsabilidade estatal quando se trata de leis inconstitucionais. Admite-se, assim, a responsabilização por danos decorrentes de toda e qualquer manifestação legislativa, com exceção daquela relativa ao poder constituinte originário, que tem por função a elaboração da Constituição. Este, por ser inicial, absoluto, ilimitado e incondicionado não submete o Estado à obrigação de reparar danos que as suas disposições venham a causar, já que cria o próprio Estado.

A responsabilidade por atos legislativos é, todavia, assunto sensível e intrincado, dada a sua natureza impactante - já que a admissão do dever indenizatório em virtude de atos legislativos pode, sobretudo quando se trata de normas gerais, implicar desequilíbrio nas finanças públicas -, a complexidade da busca do equilíbrio entre este dever, que encontra fundamento no princípio da equidade, e a noção de liberdade da atuação legislativa e, somado a isso, a inexistência, de modo geral, de qualquer sistematização no ordenamento jurídico tanto estrangeiro quanto pátrio sobre a questão.

Esses motivos, dentre outros receios, levam ainda hoje alguma doutrina e jurisprudência a titubearem a respeito de uma afirmação da responsabilidade do Estado por atos legislativos, o que, entende-se, não se coaduna com a evolução da idéia de Estado de Direito, que busca, de forma democrática, promover a justiça.

Nesse sentido, o presente estudo busca analisar o tema da responsabilidade do Estado no desempenho de sua atividade legislativa através de uma perspectiva consentânea

\footnotetext{
${ }^{188}$ Cf. ENTERRÍA, Eduardo García de. La responsabilidad patrimonial del Estado Legislador en el Derecho español. 2. ed. Navarra: Civitas, 2007, p. 175.
} 
aos atuais princípios de Direito Público, levando em conta a constante interferência estatal em âmbitos cada vez mais complexos e íntimos do particular.

É certo, contudo, que somente pode-se estabelecer um delineamento adequado do tema levando-se em conta a análise do ordenamento jurídico constitucional de cada país, uma vez que cada ordem jurídica definirá os regimes de reparação estatal, os mecanismos de controle e constitucionalidade, os efeitos da referida declaração, os princípios materiais que lhe dirigem, já que todas essas características influem sobre as hipóteses deflagradoras da responsabilidade. Diante disso, será considerado o ordenamento jurídico pátrio, sem desconsiderar, entretanto, as contribuições estrangeiras, que revelam sua importância tanto no que são semelhantes, quanto nas particularidades em relação ao direito brasileiro.

\subsection{ARGUMENTOS CONTRA A RESPONSABILIDADE CIVIL DO ESTADO POR ATOS LEGISLATIVOS: CRÍTICAS}

Previamente à análise das hipóteses em que se pode vislumbrar a responsabilidade civil do Estado pelo desempenho da função legislativa, há que se analisar os argumentos utilizados para defender a irresponsabilidade do Estado, quais sejam: a noção de lei como ato de soberania, as características de generalidade e abstração da lei, a concepção de lei como ato de criação de direitos, a representatividade dos parlamentos e a inviolabilidade dos parlamentares.

\subsubsection{A lei como ato de soberania}

Um dos primeiros e mais antigos argumentos utilizados para sustentar a tese da irresponsabilidade do Estado por atos legislativos baseia-se na noção de lei como ato de soberania, resultando dizer que ela se impõe a todos, sem que para isso possa reclamar-se compensação. Essa tese foi sustentada por Laferrière ${ }^{189}$, conforme citação de Rui Medeiros:

É princípio de que os danos causados aos particulares por medidas legislativas não lhes geram nenhum direito à indenização. A lei é, com efeito, um ato de soberania, e é próprio da soberania se impor a todos, sem que se possa reclamar alguma compensação. O legislador pode

\footnotetext{
${ }^{189}$ Traité de la jurisdiction administrative et dês recours contentieux. II. Paris, 1989 (reimp. da edição 1888), p. 12. Apud MEDEIROS, Rui. Ensaio sobre a responsabilidade civil do estado por actos legislativos. Coimbra: Almedina, 1992, p. 30.
} 
sozinho apreciar se concede essa compensação, conforme a natureza e a gravidade do dano, conforme as necessidades e os recursos do Estado: as jurisdições não podem concedê-la em seu lugar, não podem avalizar o montante, conforme os fundamentos e de acordo com as formas previstas pela lei. ${ }^{190}$. (tradução livre).

Entretanto, tal justificativa não tem sido mais acolhida pela doutrina e pela jurisprudência, já que há muito se deixou de compreender a soberania ${ }^{191}$ como apta a afastar o dever de responsabilidade extracontratual do Estado, sendo que, mais ainda, há muito já se deixou de conceber a lei como único ato que expressa soberania.

Vale ressaltar aqui, conforme já afirmado em passagem anterior ${ }^{192}$, que a idéia de soberania do Estado foi utilizada por um longo período, especialmente na época dos Estados absolutos e despóticos, para afastar o dever de indenizar por parte do Estado, porque se afirmava, dentre outros fundamentos, que o soberano não errava e, por isso, os agravos que ele causava não eram reparáveis.

Essa noção de infalibilidade de todos os atos estatais ficava ainda mais acentuada quando se tratava de atos legislativos, posto que os argumentos teóricos que influenciavam a época relacionavam a soberania ao poder de legislar.

Entretanto, ao longo da História, as modificações econômicas e sociais que influenciaram a própria concepção de Estado e, no mesmo sentido, o modo de compreender a lei e todo o processo que a envolve, inclusive em relação ao aspecto subjetivo (daquele que a elabora), demonstram não apenas a queda desse entendimento, mas a sua total contraposição: nos tempos atuais observa-se o caráter transitório do ato legislativo, a sua incapacidade de sintetizar e resolver os problemas de uma sociedade cada vez mais complexa e tecnológica, o seu desvio da noção de ato como expressão da vontade

\footnotetext{
190 "Il est de principe que les dommages causes à des particuliers par des mesures législatives ne leur ouvrent aucun droit à indemnité. La loi est, en effect, um acte de souveraineté, et le propre de la souveraineté et de s'imposer à tous, sans qu'on puisse reclamer d'elle aucune compensation. Le législateur peut seul apprécier, d'aprés la nature et la gravité du dommage, d'après les necessités et les ressources de l'État, s'il doit accorder cette compensation: les jurisdictions ne peuvent pas l'aller à sa place, elles ne peuvent qu'en évaluer le montant, d'après les bases et dans les formes prévues par la loi".

${ }^{191}$ Há que se ressaltar aqui que soberania não é um termo unívoco, havendo várias concepções a seu respeito. Aderson de Menezes, após anotar tal divergência, enuncia: "pelo que é de todo em todo procedente definir o conceito de soberania como a qualidade que o Estado possui, na esfera de sua competência jurídica, de ser supremo, independente e definitivo, dispondo, portanto, de decisões ditadas em último grau pela sua própria vontade e que pode impor inclusive pela força coativa". MENEZES, Aderson de. Teoria Geral do Estado. (Atual. por José Lindoso). Rio de Janeiro: Forense, 1999, pp. 147-149.

${ }^{192}$ Cf. Primeira Parte, Capítulo 1 deste trabalho.
} 
geral para expressar uma vontade política, fatores que levam a sua desvalorização e constante desrespeito por parte dos integrantes da sociedade.

Fala-se mesmo na crise da lei, fato que, como lembra Manoel Gonçalves Ferreira Filho, liga-se à falência dos Parlamentos como legisladores ${ }^{193}$.

Nota-se que, se durante muito tempo a lei foi considerada como intocável, cabendo a completa submissão a ela, já que era considerada "a razão humana manifesta pela vontade geral em que se encarna e expressa pelos representantes do povo"194, hoje, o evidente descrédito em que se encontra, conjugado a fenômenos como o da hiperconstitucionalização do sistema ${ }^{195}$, permitem cada vez mais o avanço do seu controle, especialmente o realizado no âmbito judicial, em face da Carta Constitucional.

Arraiga-se, assim, a consciência da falibilidade do ato legislativo, o que alarga o leque de possibilidades capazes de dar ensejo a uma ação de indenização em face do Estado. Neste sentido, Miguel Marienhoff ${ }^{196}$ posiciona-se:

Atualmente impera a convicção de que soberania - da qual uma de suas expressões típicas seria a atividade legislativa - de modo algum implica em 'infalibilidade'. Prova disto se constitui as numerosas leis que são declaradas nulas por serem inconstitucionais - é dizer - errôneas - já que aparecem vulnerando algum valor ou direito essencial protegido ou amparado pela Constituição. E se soberania não implica 'infalibilidade', menos ainda traduz-se em 'impunidade': daí ser possível a responsabilidade estatal por atos legislativos irregulares ${ }^{197}$. (tradução livre)

\footnotetext{
${ }^{193}$ FERREIRA FILHO, Manoel Gonçalves. Do processo legislativo. São Paulo: Saraiva, 2007, p. 14.

${ }^{194}$ Burdeau, Georges. Essai sur l'évolution de la notion de loi en droit français. Archives de Plilosophie du Droit et de Sociologie Juridique. n. 1 e 2, Paris, 1939.1-2 :12. Apud FERREIRA FILHO, Manoel Gonçalves. Do processo legislativo. São Paulo: Saraiva, 2007, p. 14.

195 Nas palavras de Carlos de Cabo Martín: "La sustitución del Principio de legalidad por el de constitucionalidad como eje del ordenamiento jurídico se ve potenciado por lo que puede llamarse la tendencia hacia la hiperconstitucionalización del sistema; se trata de extender progressivamente el ambito y aplicación de la Constitución reduciendo simultáneamente los de la ley”. MARTíN, Carlos de Cabo. Sobre el concepto de ley. Madrid: Trotta, 2000, p. 80.

196 MARIENHOFF, Miguel. Responsabilidad del Estado por su actividad legislativa. Revista de Direito Público. São Paulo, n. 68, pp. 5-18, out./dez., 1983, p. 7.

197 "Actualmente impera la convicción de que soberanía - una de cuyas expresiones típicas sería la actividad legislativa - en modo alguno implica 'infalibilidad'. Prueba de ello lo constituyen las numerosas leyes que son declaradas nulas por ser inconstitucionales - es decir - erróneas - ya que aparecen vulnerando algún valor o derecho esencial protegido o amparado por la Constitución. Y si soberanía no implica 'infalibilidad', menos aún trasunta 'impunidad': de ahí posible responsabilidad estatal por sus actos legislativos irregulares".
} 
Maria Emília Mendes Alcântara também destaca que essa idéia de soberania como ato incontrastável reduziu-se a nada, já que hoje a lei encontra-se submetida à Constituição $^{198}$.

Entretanto, conforme se verá ao longo deste trabalho, não é só diante da existência da falha na atividade legislativa que se tem o pressuposto para a responsabilização do Estado Legislador. Atos legislativos perfeitamente válidos poderão dar ensejo a atuação desse mecanismo de consagração e proteção aos direitos dos particulares, desde que presentes os pressupostos que o orientam.

\subsubsection{A lei como ato geral e abstrato}

Um segundo motivo para afastar o dever de indenização do Estado por atos legislativos circunscreve-se ao entendimento da lei como ato dotado de características de impessoalidade, generalidade e abstração. Dadas essas qualidades, não poderia a lei causar prejuízo a um particular, pois a ele não se dirige, de modo que tal ato não seria capaz de gerar o direito a receber uma indenização por parte do Estado.

Considera-se que se algum ônus decorre da lei, por ser esta uma norma geral e abstrata, logo ele se divide entre todas as pessoas que se encontram na mesma situação, de modo que não há quebra do princípio da igualdade de todos perante os ônus e encargos sociais.

Mais uma vez é de se reafirmar que a justificativa baseia-se numa concepção histórica tanto do Estado quanto da lei que hoje não mais subsiste.

A admissão de leis específicas, que também podem ser chamadas de leis-medida, descaracteriza a tese que pugnava pela irresponsabilidade fundamentada na idéia de que a lei provocava a repartição dos ônus e encargos sociais. Os diferentes tipos de normas, bem como a produção de efeitos laterais ou acessórios decorrentes da lei - ainda que esta apresente características de generalidade e abstração -, que impliquem danos anormais e especiais aos direitos dos particulares, possibilitam a responsabilização estatal pelo ato legislativo.

198 ALCÂNTARA, Maria Emília Mendes. Responsabilidade do Estado por atos legislativos e jurisdicionais. São Paulo: Editora Revista dos Tribunais, 1988, p. 54. 
Observa-se hoje que leis de efeitos concretos atingem situações jurídicas individuais e causam danos. Não se desconsidera, todavia, que leis genéricas e abstratas podem, através de sua aplicação, também gerar danos. Nesse sentido, Maria Emília Mendes Alcântara ${ }^{199}$ salienta que:

(...) se é certo que o ato legislativo pode, em princípio e tradicionalmente, ser caracterizado como geral, abstrato e impessoal, não é menos revestido de certeza o fato de que sua aplicação não pode se dar em relação a uma única pessoa ou a um grupo determinado de pessoas, e a estas especificamente causar danos.

Muitas vezes, uma lei a título de impor limitações à generalidade dos indivíduos, termina por impor sacrifícios especiais e anormais a uma parcela da coletividade. O interesse geral que se visava atingir é alcançado, na espécie, através do sacrifício de interesses individuais determinados, devendo pois serem ressarcidos.

Daí que a lei geral e abstrata pode, quando de sua aplicação, atingir direitos subjetivos, gerando danos aos particulares. Como destaca Maurício Zockun, a lei pode produzir efeitos em relação a pequeno grupo de pessoas, ainda que diretamente volvida a todas as camadas da sociedade, de modo, então, que as conseqüências prescritas não são gerais, mas sim especiais ${ }^{200}$.

Sendo suas consequiências causadoras de prejuízos especiais e anormais, além de certos, ou seja, decorrendo de sua aplicação um dano antijurídico, será deflagrada a responsabilidade civil estatal, que é una, independentemente de tratar-se especificamente de ato administrativo, legislativo ou jurisdicional.

\subsubsection{A lei como ato de criação dos direitos}

Uma terceira razão utilizada para a defesa da irresponsabilidade do Estado por atos legislativos é no sentido de que é ínsita à atividade de legislar a possibilidade de modificar a lei, podendo mesmo ocorrer a alteração ou a extinção de direitos que leis anteriores reconheciam. A lei não violaria nenhum direito preexistente, porque esses direitos deixariam de existir ou de ser como eram, no mesmo momento em que a lei nova os houver extinguido ou modificado.

\footnotetext{
199 ALCÂNTARA, Maria Emília Mendes. Responsabilidade do Estado por atos legislativos e jurisdicionais. São Paulo: Revista dos Tribunais, 1988, pp. 54-55.

200 ZOCKUN, Maurício. A matriz constitucional da responsabilidade do Estado, a responsabilidade do Estado por atos legislativos e a obrigatoriedade de prévia indenização. Tese (Doutorado em Direito). Faculdade de Direito - Pontifícia Universidade Católica de São Paulo, São Paulo, 2009, p. 134.
} 
Marisa Helena D`Arbo Alves ${ }^{201}$ de Freitas, expondo as idéias de Varela e Duez, principais defensores desse argumento, assim sintetiza a opinião dos autores:

Pondera-se que, sendo a configuração do direito dada pela lei, esta, ao criá-lo e delimitá-lo, não pode atentar contra ele. Assim, quando a lei limita direitos anteriormente concedidos, traz encargos que devem ser suportados pelos indivíduos como membros da sociedade.

Acrescenta-se a essa consideração o argumento de que a admissão da responsabilidade do Estado por atos legislativos implicaria a paralisação da atividade legislativa, ou seja, o simples fato de legislar, ao atingir direitos dos particulares, constituiria hipótese de responsabilidade, de modo que tal circunstância acabaria por levar o Estado a interromper sua atividade legiferante.

Fossem corretas tais concepções, por certo inexistiria a defesa do direito adquirido e seus correlatos (ato jurídico perfeito e coisa julgada) no ordenamento pátrio. É de se observar que a própria Constituição, com vistas a proporcionar segurança e estabilidade nas relações jurídicas, protege a eficácia dos direitos e relações jurídicas constituídas sob determinadas normas, como se observa do disposto no artigo $5^{\circ}$, inciso XXXVI, da CF, ainda que seus efeitos não hajam sido produzidos por falta de vontade do titular do direito, diante do surgimento da lei nova.

A Lei de Introdução ao Código Civil, que é tida como parâmetro de interpretação de todo o ordenamento jurídico pátrio, em seu artigo $6^{\circ}$ também destaca a impossibilidade de normas novas interferirem no direito que passou a integrar o patrimônio material ou moral do sujeito, regulando a matéria da seguinte forma:

Lei de Introdução ao Código Civil - Decreto-lei 4.657/42 - Redação de acordo com o artigo $1^{\circ}$ da Lei 3.238/57

Art. $6^{\circ}$. A lei em vigor terá efeito imediato e geral, respeitados o ato jurídico perfeito, o direito adquirido e a coisa julgada.

$\S 1^{\circ}$. Reputa-se ato jurídico perfeito o já consumado segundo a lei vigente ao tempo em que se efetuou.

$\S 2^{\circ}$. Consideram-se adquiridos assim os direitos que o seu titular, ou alguém por ele, possa exercer, como aqueles cujo começo do exercício tenha termo prefixo, ou condição preestabelecida inalterável, a arbítrio de outrem.

$\S 3^{\circ}$. Chama-se coisa julgada ou caso julgado a decisão judicial de que já não caiba recurso.

${ }^{201}$ VARELA, L. Banco de Seguros, p. 34. DUEZ, Paulo. La responsabilité de la puissance publique. Paris: Dalloz, 1927, p. 104. Apud FREITAS, Marisa Helena D’Arbo de. Responsabilidade do Estado por atos legislativos. Franca: UNESP - FHDSS, 2001, p. 81. 
Perante direitos adquiridos, não há lei nova que possa afetar os seus contornos, pois continuam a ser regidos pela lei antiga.

Diante disso, pode-se concluir que é possível cuidar-se de indenização quando a lei nova atinge os contornos de um direito que foi devidamente constituído sob a égide da lei antiga, posto que o respeito ao direito adquirido no sistema brasileiro funciona como um limitador da atuação estatal na atividade legiferante, já que, no caso, trata-se de uma proteção de índole constitucional, inserta no capítulo dos direitos fundamentais, razão pela qual não pode o legislador ignorá-la.

O tema será retomado com maior profundidade quando for tratado da responsabilidade civil do Estado por atos legislativos constitucionais.

\subsubsection{A representatividade do órgão legislativo e a imunidade parlamentar}

Sob o prisma da representatividade, também se advoga a tese da irresponsabilidade do Estado por atos legislativos. Neste caso, argumenta-se que sendo o parlamento formado por representantes dos membros da sociedade, logo são estes mesmos os responsáveis pelos danos derivados da produção legislativa, não havendo que se falar, assim, em responsabilidade do Estado. Em outras palavras, crê-se que "a lesão causada por ato legislativo tem por autor o próprio lesado"202.

$\mathrm{O}$ argumento não parece resistir, contudo, à evolução das teorias que explicam a relação entre os agentes políticos, o Estado e o povo, nem se adequa à concepção sociológica da relação Estado-sociedade hoje vigente.

Hodiernamente, compreende-se que a relação existente entre o Estado, pessoa jurídica e seus agentes é melhor explicada pela teoria do órgão, cuja síntese estabelece que a pessoa jurídica manifesta a sua vontade por meio dos órgãos, de tal modo que quando os agentes que os compõem manifestam a sua vontade, é como se o próprio órgão o fizesse ${ }^{203}$. Logo, os parlamentares, uma vez investidos (eleitos, diplomados, empossados) tornam-se pleno iure os órgãos do Estado e, do mesmo modo que ocorre com os agentes pertencentes ao Executivo e o Judiciário, seus atos tornam-se atos imputáveis ao Estado.

${ }^{202}$ ALCÂNTARA, Maria Emília Mendes. Responsabilidade do Estado por atos legislativos e jurisdicionais. São Paulo: Editora Revista dos Tribunais, 1988, p. 56.

${ }^{203}$ DI PIETRO, Maria Sylvia Zanella. Direito Administrativo. 22. ed. São Paulo: Atlas, 2009 , p. 504. 
Igualmente o argumento utilizado para afastar a responsabilidade civil estatal hoje não mais corresponde com o processo integrativo Estado-sociedade. É bem verdade que o sufrágio universal não garante a autenticidade da representação, nem é eficaz para a constituição de órgãos de decisão voltados para o interesse geral, sendo o Parlamento atualmente um órgão que se tornou um campo de batalha composto por diferentes visões hostis que vivem se digladiando, propiciando com isso a utilização do interesse geral como uma arma em proveito das categorias sociais dominantes ${ }^{204}$.

No tocante à compreensão da inviolabilidade parlamentar como fundamento a justificar uma pretensa irresponsabilidade civil do Estado, há que se reconhecer que tal prerrogativa, disposta no artigo 53, caput da $\mathrm{CF}$, consiste numa proteção não da pessoa estatal, mas sim dos parlamentos, no sentido de assegurar a sua independência e liberdade, de modo que não pode ser considerada como um privilégio apto a afastar a sua responsabilização quando provoque danos que mereçam a devida reparação.

\subsection{HIPÓTESES DE RESPONSABILIDADE CIVIL DO ESTADO LEGISLADOR: ATOS LEGISLATIVOS INCONSTITUCIONAIS E CONSTITUCIONAIS}

Costuma a doutrina dividir as hipóteses de responsabilização do Estado Legislador em função das diferentes espécies de atos: atos legislativos constitucionais, inconstitucionais e, ainda, os casos de omissão legislativa inconstitucional ${ }^{205}$.

Há uma tendência mundial, especialmente nos países em que se permite ao Judiciário realizar o controle de constitucionalidade das leis, de aceitar a responsabilidade civil do Estado por ato legislativo inconstitucional. É o que ocorre, por exemplo, na Espanha $^{206}$, na Argentina ${ }^{207}$, em Portugal $^{208}$ e na Alemanha ${ }^{209}$.

\footnotetext{
${ }^{204}$ Cf. FERREIRA FILHO, Manoel Gonçalves. Do processo legislativo. 6. ed. São Paulo: Saraiva, 2007, p. 120. Também destacando a crise de representação que, entre outros fatores conduz à crise do Parlamento e à dessacralização da lei, ver MARTín, Carlos de Cabo. Sobre el concepto de ley. Madri: Trotta, 2000, p. 77.

${ }^{205}$ Não se desconsidera a ocorrência de hipóteses de inação legislativa que podem ser consideradas constitucionais, como observa Vanice Regina Lírio do Valle. No entanto, dentre as hipóteses consideradas como deflagradoras de responsabilidade estatal encontra-se, no tocante à inação estatal, apenas a omissão legislativa inconstitucional que não será objeto de estudo neste trabalho. VALLE, Regina Vanice Lírio do. Sindicar a omissão legislativa: real desafio à harmonia entre os poderes. Belo Horizonte: Fórum, 2007, p. 161.

${ }^{206}$ ENTERRÍA, Eduardo García de. FERNÁNDEZ, Tomás-Ramón. Curso de Derecho Administrativo. v. II. 9. ed. Madri: Civitas, 2004, pp. 419-424

${ }^{207}$ DROMI, Roberto. Derecho Administrativo. 4. ed. Buenos Aires: Ediciones Ciudad Argentina, 1995, p. 701.
} 
No Brasil, onde se permite referido controle desde a instauração da República, o entendimento majoritário tanto da doutrina quanto da jurisprudência atual não é em sentido diferente, embora hoje ainda ecoem vozes dissonantes sobre a matéria ${ }^{210}$.

É neste contexto que se pretende analisar, inicialmente, como ocorre o controle de constitucionalidade das leis no Brasil para que, diante do quadro apresentado, seja possível verificar como o reconhecimento da incompatibilidade da lei com a Constituição pode fazer atuar o instituto da responsabilidade civil do Estado Legislador: em que situações, em qual medida e extensão, entre outras questões que envolvem o tema.

Para esse exame serão recepcionadas as considerações já oferecidas por alguns autores sobre o tema no direito estrangeiro. Não se trata de um estudo propriamente de direito comparado. Entretanto, busca-se a compreensão de como a matéria vem sendo tratada e discutida em determinados países que, de alguma forma, já a enfrentaram e disciplinaram.

Após, será analisada a possibilidade de responsabilização estatal em virtude de atos legislativos constitucionais, sem a pretensão de esgotar o tema, mas apenas pincelar os principais aspectos que o permeiam.

\subsubsection{A responsabilidade civil do Estado por lei inconstitucional}

Apresenta-se, inicialmente, um quadro - sem qualquer pretensão de delinear toda a grande problemática que envolve o tema - do controle da constitucionalidade no Brasil, especialmente o realizado pelo Poder Judiciário, para que se possa adentrar na análise de como a doutrina e jurisprudência reconhecem a possibilidade de responsabilização do Estado por lei declarada inconstitucional.

Busca-se analisar os argumentos que fundamentam a responsabilidade do Estado (princípio da legalidade e da igualdade) e como tal raciocínio induz a sua aplicabilidade em razão da atuação legislativa estatal. Para tanto, será feito um exame de como a

${ }^{208}$ MEDEIROS, Rui. Ensaio sobre a responsabilidade civil do Estado por actos legislativos. Coimbra: Almedina, pp. 130-131.

${ }^{209}$ RIBEIRO, Martha Chantal da Cunha Machado. Da responsabilidade do Estado pela violação do direito comunitário. Coimbra: Almedina,1996, p. 110.

${ }^{210}$ Hely Lopes Meirelles entende que não existe fundamento jurídico para a responsabilização civil da Fazenda Pública por danos eventualmente causados por lei, ainda que declarada inconstitucional. Cf. MEIRELLES, Hely. Direito Administrativo brasileiro. 35. ed. São Paulo: Malheiros, 2009, p. 665. 
inconstitucionalidade da lei pode ou não ser reconhecida como pressuposto do dever indenizatório num sistema que pugna pela responsabilidade de forma objetiva.

Questiona-se o quanto será necessário reconhecer a inconstitucionalidade para declarar-se a responsabilidade diante do regime adotado pela Constituição no Brasil. Será também possível falar em diferenças, no tocante à responsabilização estatal, em relação a uma declaração de inconstitucionalidade com eficácia ex nunc ou ex tunc? A eficácia ex nunc postulará a rejeição das pretensões de indenização com fundamento na norma declarada inconstitucional?

Essas são questões que não se deixará de enfrentar ao longo deste capítulo.

\subsubsection{Considerações sobre o controle de constitucionalidade no Brasil}

Num sistema de Constituição rígida, demanda-se um processo mais complicado e solene para reforma das disposições constitucionais (maioria qualificada, votação repetida em casas legislativas sucessivas, ratificação pelos Estados-membros em algumas organizações federativas, etc.) do que ocorre em relação às demais leis. Tal processo confere às normas constitucionais uma estabilidade ou rigidez diferenciada, que resulta na supremacia incontrastável da lei constitucional sobre as demais regras em determinado ordenamento, criando, assim, uma hierarquia jurídica que se estende da norma constitucional às demais normas do referido ordenamento.

Essa supremacia, por óbvio, impede que, no desempenho da função legislativa, o Estado produza normas que contrariem os preceitos da Constituição, sob pena de serem tais normas reputadas como nulas, despidas de validade.

É com vistas a concretizar a supremacia constitucional que se consagram mecanismos para impedir que leis inconstitucionais permaneçam ou ingressem na ordem jurídica estabelecida. Esses instrumentos permitem a verificação da compatibilidade vertical entre os atos normativos e a Constituição, e podem ser tanto preventivos quanto repressivos.

Sob o ângulo da natureza do órgão que realiza o controle de constitucionalidade, este pode ser decomposto em: controle político, quando praticado por órgão excluído da 
estrutura do Poder Judiciário; controle judicial, praticado por órgão pertencente ao Poder Judiciário.

No Brasil, onde se proclama uma Constituição rígida, adota-se, como regra, o controle judicial da constitucionalidade, cujo fundamento encontra-se no artigo 102, caput, combinado com os seus incisos I, alínea "a" e III, alíneas "a", "b” e "c", e também o artigo 103, $\S \S 1^{\circ}$ a $3^{\circ}$, da Constituição Federal. Esses dispositivos determinam a competência do Supremo Tribunal Federal para realizar, precipuamente, a guarda da Constituição, hipótese que se expressa na possibilidade dessa Corte processar e julgar a ação direta de inconstitucionalidade de lei ou ato normativo federal ou estadual, bem como a ação direta de inconstitucionalidade por omissão e a ação declaração de constitucionalidade de lei ou ato normativo federal ou, ainda, de apreciar, em sede de recurso extraordinário, a decisão proferida em única ou última instância que contrarie dispositivo da Carta Magna, que declare a inconstitucionalidade de tratado ou lei federal ou julgue válida lei ou ato de governo local contestado em face do texto constitucional.

Os artigos citados contemplam, em suma, a possibilidade de a inconstitucionalidade ser declarada tanto em face da ação legislativa quanto diante da sua omissão. Entretanto, em vista do foco deste trabalho, será discutida apenas a inconstitucionalidade por ação.

Vale salientar apenas que, embora a fiscalização da constitucionalidade caiba, principalmente, aos órgãos do Poder Judiciário, posto que a este incumbe dizer de forma definitiva acerca da interpretação da Constituição, os demais poderes também podem exercitá-la, conforme já consagrou a jurisprudência do próprio Supremo Tribunal Federal $^{211}$.

No que é pertinente ao modelo de controle judicial adotado no país, pode-se dizer que a Constituição Federal consagra um sistema misto, pois possibilita tanto um controle difuso quanto concentrado: a) ora o controle pode ser exercido pela via de exceção (forma

\footnotetext{
${ }^{211}$ Brasil. Supremo Tribunal Federal. Recurso em Mandado de Segurança no $14.553 /$ MG. Recorrente: Clóvis da Silva Araújo e outro. Recorrida: Prefeitura Municipal de Ipanema. Relator: Luiz Galotti. J. 13.04.65. Revista Trimestral de Jurisprudência, Brasília, v.33, n. 2, p.328-336, ago./1965, p. 336. E também conforme restou assentado na ementa do julgamento da Medida Cautelar da ADIN no 221/DF: “(...)os Poderes Executivo e Legislativo, por sua Chefia - e isso mesmo tem sido questionado como o alargamento da legitimação ativa na ação direta de inconstitucionalidade -, podem deixar de aplicar administrativamente as leis ou atos com força de lei que considerem inconstitucionais.”. Tribunal Pleno. Requerente: Procurador Geral da República. Requerido: Presidente da República. Relator: Ministro Moreira Alves. J. 20.03.90. DJ 22.10.1993. Disponível em: http://redir.stf.jus.br/paginador/paginador.jsp?docTP=AC\&docID=346262\&pgI=1\&pgF=100000. Acesso em: 08.07.2009.
} 
difusa): quando, no curso de um pleito judiciário, uma das partes levanta, em defesa de sua causa, a objeção de inconstitucionalidade da lei que se lhe quer aplicar; b) ora pela via de ação (forma concentrada), que permite o controle da norma in abstrato, ou seja, o mérito da ação é a impugnação direta da norma em face ao texto constitucional. Cabe esclarecer que este último é exercido independentemente de um caso concreto ou de um litígio entre as partes, tendo por objetivo a aferição, em tese, da constitucionalidade da norma cuja compatibilidade com o texto constitucional é controversa.

Quanto à origem do vício, tem-se que uma lei pode contrariar as normas ou princípios consagrados na Constituição de duas formas: a) pela não obediência aos requisitos formais ou aos procedimentos estabelecidos para elaboração do ato legislativo, onde se tem a então denominada inconstitucionalidade formal; b) pela contrariedade da lei ao conteúdo disposto no texto constitucional, o que então é denominado inconstitucionalidade material.

Oportuno salientar que nada impede a coexistência da inconstitucionalidade formal e material em um mesmo ato legislativo, já que se trata de vícios distintos. Entretanto, tanto a existência de um como de outro, no plano da invalidade da norma, geram a mesma consequência. Questão que se discute, entretanto, como se verá adiante, é se em relação à responsabilidade civil do Estado podem surgir diferenças quando se trate de uma lei formalmente e uma lei materialmente inconstitucional.

Classifica-se, ainda, a inconstitucionalidade em razão da ocasião do vício. Neste sentido, pode-se dizer que ela é originária ou superveniente. A primeira se expressa desde o momento do ingresso da norma no mundo jurídico, seja do ponto de vista formal ou material. Já a segunda ocorre em momento posterior à produção da norma alvo do controle, em razão da reforma ou mutação constitucional.

Controvérsia existe, entretanto, seja no âmbito da doutrina quanto da jurisprudência, em relação aos efeitos produzidos com a declaração de inconstitucionalidade. Há que se explicitar tais efeitos em razão do tipo de controle que está sendo exercido: se de forma incidental ou por meio de um controle abstrato.

No tocante ao controle concentrado, a decisão de inconstitucionalidade pode ser declarada com efeitos erga omnes (com relação a todos) e vinculante, relativamente aos 
demais órgãos do Poder Judiciário e da Administração Pública Direta e Indireta, nas esferas federal, estadual e municipal.

No entanto, a doutrina não é uníssona em relação ao momento em que a lei inconstitucional deixa de ser aplicada. Mais apropriado dizer, conforme pondera José Afonso da Silva, que a discussão dos efeitos da declaração de inconstitucionalidade remete ao problema da natureza do ato inconstitucional: ato inexistente, nulo ou anulável ${ }^{212}$.

Essa discussão é importante para o tema da responsabilidade do Estado Legislador, pois entre a edição da lei inconstitucional e sua retirada do ordenamento jurídico através dos mecanismos de controle podem ter sido praticados atos materiais e jurídicos com base na lei que, se posteriormente declarada inconstitucional - conforme afirmam alguns autores - sequer poderia ter sido considerada como existente.

É o que entende Francisco Campos ao dizer que "uma lei inconstitucional não é lei, nem poderia ser, jamais, como tal considerada. Ela era o que é e continuará a ser, isto é coisa nenhuma em Direito, antes e depois da declaração de inconstitucionalidade" ${ }^{213}$.

Caio Tácito, por sua vez, afirma que "as leis inconstitucionais não geram direitos adquiridos, nem à sombra delas podem prosperar situações jurídicas legítimas e respeitáveis". Para o autor, a lei inconstitucional não é verdadeiramente uma lei, sendo apenas um ato emanado do Congresso ${ }^{214}$.

Alfredo Buzaid entende que toda lei adversa à Constituição é absolutamente nula, não simplesmente anulável ${ }^{215}$.

Esse entendimento é também tradicionalmente consagrado pelo Supremo Tribunal Federal, que elegeu a nulidade da lei inconstitucional como uma regra, pacificando a necessidade de retroação dos efeitos da decisão de inconstitucionalidade, conforma relata Ana Paula Oliveira Ávila ${ }^{216}$ e se observa do voto proferido pelo Ministro Celso de Mello,

${ }^{212}$ SILVA, José Afonso da. Curso de Direito Constitucional Positivo. 32. ed. São Paulo: Malheiros, 2009, pp. $52-53$.

${ }^{213}$ CAMPOS, Francisco. Direito Constitucional. v. I. São Paulo - Rio de Janeiro: Freitas Bastos, 1956, p. 440.

${ }^{214}$ TÁCITO, Caio. Anulação de Leis Inconstitucionais. Temas de Direito Público. vol. 2. Rio de Janeiro: Renovar, pp. 1069 - 1070.

${ }^{215}$ BUZAID, Alfredo. Da ação direta de inconstitucionalidade no direito brasileiro. São Paulo: Saraiva, 1958, p. 128.

216 ÁVILA, Ana Paula Oliveira. A modulação de efeitos temporais pelo STF no controle de constitucionalidade. Porto Alegre: Livraria do Advogado, 2009, p. 47. 
relator da decisão proferida na Questão de Ordem da Ação Direta de Inconstitucionalidade $\mathrm{n}^{\mathrm{o}} 652-5 / \mathrm{MA}^{217}$ :

(...) Atos inconstitucionais são, por isso mesmo, nulos e destituídos, em conseqüência, de qualquer carga de eficácia jurídica. - A declaração de inconstitucionalidade de uma lei alcança, inclusive, os atos pretéritos com base nela praticados, eis que o reconhecimento desse supremo vício jurídico, que inquina de total nulidade os atos emanados do poder público, desampara as situações constituídas sob sua égide e inibe - ante a sua inaptidão para produzir efeitos jurídicos válidos - a possibilidade de invocação de qualquer direito (...)

No entanto, embora tenha como regra a declaração de inconstitucionalidade com efeitos ex tunc, o próprio Supremo Tribunal Federal, antes do advento da Lei 9.868/99, enfrentava dissidências na aplicação desse entendimento, deparando-se com outras circunstâncias e argumentos que não permitiam a desconstituição de fatos pretéritos, ainda que baseados em lei inconstitucional. Exemplos dessas circunstâncias podem ser observados nas decisões proferidas no Recurso Extraordinário no ${ }^{\circ} 105.789$, Relator Ministro Carlos Madeira, de 15 de abril de $1986^{218}$, e no Recurso Extraordinário no 122.202 , Relator Ministro Francisco Rezek, de 10 de agosto de $1993^{219}$, nas quais não foi aplicada a regra da declaração de inconstitucionalidade com efeitos ex tunc.

No âmbito doutrinário, também havia resistência de certos autores em admitir a declaração de inconstitucionalidade com efeitos tão radicais. José Afonso da Silva, por exemplo, defende que a doutrina privatista da invalidade dos atos jurídicos não poderia ser

${ }^{217}$ BRASIL. Supremo Tribunal Federal. ADIN 652- MA Questão de Ordem. Relator: Ministro Celso de Mello. Julgado em 2 de abril de 1992. DJ 02/04/93. Disponível em: http://www.stf.jus.br/portal/inteiroTeor/obterInteiroTeor.asp?numero=652\&classe=ADI. Acesso em: 19.12.2009.

${ }^{218}$ BRASIL. Supremo Tribunal Federal. Ementa: "Magistrado. Garantia constitucional da irredutibilidade de vencimento. A nova qualificação do tempo de serviço, anos depois de averbado e de haver produzido efeitos pecuniários em favor do magistrado, malfere a garantia constitucional da irredutibilidade de vencimentos, que torna intangível o direito que já nasceu e não pode ser suprimido sem que sejam diminuídas as prerrogativas que suportam o seu cargo. Recurso conhecido e provido". Recurso Extraordinário. RE 105.789. Relator: Ministro Carlos Madeira. Segunda Turma. Julgado em 15/04/1986. DJ 09-05-1986. Disponível em: http://www.stf.jus.br/portal/inteiroTeor/obterInteiroTeor.asp?numero=105789\&classe=RE. Acesso em 19.12.2009.

219 BRASIL. Supremo Tribunal Federal. Ementa: "Recurso Extraordinário. Efeitos da declaração de inconstitucionalidade em tese pelo Supremo Tribunal Federal. Alegação de direito adquirido. Acórdão que prestigiou lei estadual à revelia da declaração de inconstitucionalidade desta última pelo Supremo. Subsistência de pagamento de gratificação mesmo após a decisão erga omnes da Corte. Jurisprudência do STF no sentido de que a retribuição declarada inconstitucional não é de ser devolvida no período de validade inquestionada da lei de origem - mas tampouco paga após a declaração de inconstitucionalidade. Recurso extraordinário provido em parte". RE 122.202. Relator: Ministro Francisco Rezek. Segunda Turma, Julgado em 10/08/1993. DJ 08-04-1994. .Disponível em: http://www.stf.jus.br/portal/inteiroTeor/obterInteiroTeor.asp?numero=122202\&classe=RE.. Acesso em: 19.12.2009. 
transposta para o campo da inconstitucionalidade, pelo menos no direito brasileiro, que estruturou uma técnica peculiar de controle ${ }^{220}$.

Inobstante as divergências apresentadas, é certo que com o advento da Lei 9.868/99 oficializou-se, no direito brasileiro, a possibilidade de declaração de inconstitucionalidade da lei com efeitos ex nunc ou pro futuro. $\mathrm{O}$ artigo 27 desse diploma legal permitiu que, excepcionalmente, o Supremo Tribunal Federal manipulasse os efeitos da declaração de inconstitucionalidade com o voto da maioria de dois terços dos seus membros. Os efeitos da declaração poderiam ser fixados desde o trânsito em julgado ou de outro momento a ser decidido pelo referido órgão.

Possibilitou-se, assim, de forma expressa, que nos casos em que a segurança jurídica ou o excepcional interesse público o exigissem, poderia o STF declarar os efeitos da inconstitucionalidade de forma ex nunc ou, ainda, pro futuro.

Nota-se, com isso, que houve um distanciamento entre a nulidade e a inconstitucionalidade da lei, o que permitiu a proteção e a incontestabilidade de determinadas relações jurídicas em face do reconhecimento da inconstitucionalidade da lei.

Frente a esse fato, pode-se dizer, em suma, que no controle de constitucionalidade concentrado acolhido no Brasil, consubstanciado por meio da ação direta de inconstitucionalidade genérica, os efeitos da sentença que declara a inconstitucionalidade são, em regra, ex tunc, podendo, entretanto, ser dado efeito ex nunc ou pro futuro se houver manifestação de dois terços dos Ministros da Corte Suprema, que observará o cumprimento dos requisitos materiais para tanto.

Diferentemente, entretanto, são os efeitos alcançados na hipótese de reconhecimento da inconstitucionalidade por meio do controle difuso. Primeiramente, quanto ao âmbito subjetivo da decisão, pode-se dizer que no direito pátrio, tradicionalmente, entende-se que a decisão acerca da questão prejudicial da inconstitucionalidade restringe-se ao caso concreto em análise, posto que, nos termos do artigo 52, inciso X, da Carta Magna, caberia ao Senado decidir a respeito da eficácia erga omnes do referido julgamento.

${ }^{220}$ SILVA, José Afonso da. Curso de Direito Constitucional Positivo. 32. ed. São Paulo: Malheiros, 2009, p. 53. 
Com relação à eficácia temporal dessa decisão, em sendo proferida a resolução do Senado que suspende a execução da lei declarada inconstitucional num determinado caso concreto, a doutrina apresenta duas posições contraditórias a respeito do tema: uma defendendo a eficácia retroativa (ex tunc) e outra defendendo a eficácia prospectiva (ex nunc).

Para Themístocles Brandão Cavalcanti, José Afonso da Silva e Guilherme Peña de Moraes $^{221}$, a eficácia da suspensão operaria após a edição da resolução, não alcançando os atos jurídicos perfeitos e direitos adquiridos na vigência do ato declarado inconstitucional pelo STF. Trata-se, portanto, segundo o entender dos referidos doutrinadores, de uma decisão com eficácia ex nunc.

De forma diversa, para Gilmar Ferreira Mendes ${ }^{222}$, não há que se cogitar de "atos jurídicos perfeitos" ou de "efeitos futuros de direitos adquiridos", com fulcro em lei inconstitucional. Isto porque se afirma no direito pátrio, quase de forma unânime, que a pronúncia de inconstitucionalidade tem efeito ex tunc, de modo que a decisão judicial teria eminente caráter declaratório. No mesmo sentido, como já se afirmou, o entendimento expresso, em regra, pelo STF.

Entretanto, o próprio Ministro Gilmar Ferreira Mendes compreendeu que tal eficácia também encontra limites, conforme consta do seu voto proferido na Reclamação Constitucional $\mathrm{n}^{\circ}$ 4.335:

Evidentemente, esta eficácia ampla deve ser entendida com temperamentos. A pronúncia da inconstitucionalidade não retira do mundo jurídico, automaticamente, os atos praticados com base na lei inconstitucional, criando apenas condições para eventual desfazimento ou regulação dessas situações. Tanto a coisa julgada como outras fórmulas de preclusão podem tornar irreversíveis as decisões ou atos fundados na lei censurada. Assim, operada a decadência ou a prescrição, ou decorrido in albis o prazo para a propositura da ação rescisória, não há mais que se cogitar da revisão do ato viciado.

Cabe salientar que, atualmente, os Ministros do Supremo Tribunal Federal apresentam uma postura dúbia a respeito dos limites subjetivos da eficácia da declaração de inconstitucionalidade em sede de controle difuso. É o que se observa das posições

221 Conforme levantamento feito por Guilherme Peña de Moraes. Direito Constitucional: Teoria da Constituição. 4. ed. Rio de Janeiro: Lúmen Júris, 2007, p. 165.

${ }^{222}$ Observação realizada quando do voto proferido na Reclamação Constitucional $\mathrm{n}^{\circ}$ 4.335. Conforme constante no Informativo $n^{\circ} 463$ do Supremo Tribunal Federal. Brasília, 16 a 20 de abril de 2007. Disponível em: http://www.stf.jus.br/arquivo/informativo/documento/informativo463.htm. Acesso em: 27.06.2009. 
proferidas no julgamento da Reclamação Constitucional $\mathrm{n}^{\circ} 4.335$, que tem por objeto a aplicação com efeitos erga omnes da decisão que declarou, de forma incidente, a inconstitucionalidade do artigo $2^{\circ}, \S 1^{\circ}$ da Lei ${ }^{\circ}$ 8.072/90 (Lei de Crimes Hediondos), independentemente da resolução emitida pelo Senado.

Apenas para situar o leitor, cabe aqui tecer um resumo do caso para que se compreenda a discussão travada.

A Reclamação $n^{\circ} 4.335$ - Acre foi ajuizada pela Defensoria Pública da União contra decisão do juiz da Vara de Execuções Penais de Rio Branco (AC), na qual este não avaliou o pedido de progressão de regime para dez condenados por crimes hediondos. Sustentou o juiz que existe vedação legal para admitir a progressão de regime para crimes hediondos e que a decisão do STF que declarou a inconstitucionalidade desta proibição foi dada em um pedido de Habeas Corpus (HC 82.959), de modo que gerava efeitos apenas para aquele caso específico.

A questão ainda não está decidida, porém vislumbra-se a existência de posicionamentos, como os dos Ministros Gilmar Ferreira Mendes e Eros Roberto Grau, no sentido de que a referida declaração feita de forma incidental geraria efeitos contra todos, independentemente da intervenção do Senado Federal.

Dentre os argumentos apontados pelo Ministro Gilmar Mendes, estaria o fato de que a própria Corte Suprema, ao julgar inconstitucional a proibição da progressão de regime através do controle incidental (HC 82.959), previu que tal decisão teria efeito ex nunc. Tal significaria, implicitamente, uma consideração de efeito erga omnes à decisão, o que acabaria por acarretar uma forte debilitação da intervenção do Senado Federal nesta questão.

Diferentemente é a posição do Ministro Sepúlveda Pertence, que julgou a reclamação improcedente, embora tenha reconhecido a dispensabilidade da reserva de plenário (artigo 97 da Constituição), quando já houvesse declaração de inconstitucionalidade de determinada norma legal pelo Supremo Tribunal Federal, ainda que em via de controle incidental, em razão dessa circunstância quebrar a presunção de constitucionalidade que reveste qualquer lei ou ato normativo. O Ministro reportou-se aos fundamentos do voto que proferiu no julgamento do RE 191.896/PR, julgado em 27/05/97, cuja ementa sintetiza que: 
(...) a decisão plenária do Supremo Tribunal declaratória de inconstitucionalidade da norma, posto que incidente, sendo pressuposto necessário e suficiente a que o Senado lhe confira efeitos erga omnes, elide a presunção de sua constitucionalidade; a partir daí, podem os órgãos parciais dos outros tribunais acolhê-la para fundar a decisão de casos concretos ulteriores, prescindindo de submeter a questão de constitucionalidade ao seu próprio plenário ${ }^{223}$

Não admitiu o referido Ministro que a declaração incidental da inconstitucionalidade tenha efeitos erga omnes, posto que no seu entendimento isto reduziria o Senado a um mero órgão de publicidade das decisões do Supremo Tribunal Federal. O meio capaz de elidir a insegurança trazida pela controvérsia a respeito da constitucionalidade da norma poderia, então, ser resolvido através de uma súmula vinculante editada pelo Supremo. Em suma, sua opinião é no sentido de que o controle incidental não teria o condão de retirar, com relação a todos, a validade da lei ${ }^{224}$.

Já o Ministro Joaquim Barbosa não conheceu da reclamação, mas conheceu do pedido como habeas corpus e o concedeu de ofício. Considerou que a suspensão da execução da lei pelo Senado seria um complemento à ampla efetividade das decisões do Supremo, fazendo, assim, uma leitura tradicional do artigo 52, inciso X, da Constituição: seria uma autorização ao Senado para determinar a suspensão de execução do dispositivo tido por inconstitucional e não de uma faculdade de cercear a autoridade do STF. Também defendeu, como fez o Ministro Sepúlveda Pertence, a possibilidade de edição de súmula vinculante para a situação ${ }^{225}$.

Nota-se que, embora não se tenha um posicionamento firmado a respeito do alcance da declaração incidental da inconstitucionalidade da norma legal por meio do controle incidental, tem-se como unânime a posição de que tal reconhecimento, ainda que feito pelo STF no julgamento de um caso específico, quebra a presunção da constitucionalidade do ato legislativo, o que levanta a possibilidade de questionar-se em que medida a mitigação deste invólucro pode servir de pressuposto para ensejar a responsabilização do Estado.

Em face de todas essas considerações, pode-se extrair daqui algumas conclusões que nortearão o estudo a respeito da responsabilidade do Estado por lei inconstitucional:

\footnotetext{
223 Primeira Turma. Relator: Ministro Sepúlveda Pertence. DJ 29/08/97. Disponível em: http://redir.stf.jus.br/paginador/paginador.jsp?docTP=AC\&docID=232399\&pgI=1\&pgF=100000. Acesso em: 13.10 .09 .

224 Cf. Informativo $\mathrm{n}^{\mathrm{o}} 463$ do STF. Brasília, 16 a 20 de abril de 2007. Disponível em: https://www.stf.jus.br//arquivo/informativo/documento/informativo463.htm . Acesso em: 27.06.09.

${ }^{225} \mathrm{Cf}$. Informativo $\mathrm{n}^{\circ} 463$ do STF.
} 
a. no ordenamento pátrio, algumas situações jurídicas encontram proteção e merecem ser mantidas, ainda que fundamentadas em lei posteriormente reconhecida como inconstitucional ${ }^{226}$;

b. a declaração de inconstitucionalidade de forma incidental pelo plenário do STF quebra a presunção de constitucionalidade da lei, servindo como um precedente para que outras decisões também reconheçam essa inconstitucionalidade, até que uma decisão definitiva e com eficácia erga omnes seja proferida.

\subsubsection{A inconstitucionalidade da lei e a responsabilidade civil do Estado Legislador}

Ao tratar da importância do instituto da responsabilidade do Estado Legislador nas hipóteses decorrentes de lei declarada inconstitucional, Júlio César dos Santos Esteves afirma que "a intangibilidade da Constituição não se garante com a mera supressão do diploma normativo da ordem jurídica". Daí afirmar que a repulsa só se fará de modo completo se restabelecidos os direitos individuais afetados pela lei inconstitucional ${ }^{227}$.

Bem sucedida a posição do autor ao reconhecer que o instituto da responsabilidade, conforme já mencionado em momento anterior neste trabalho, apresenta-se como um reforço da proteção aos direitos fundamentais, na medida em que requer a análise das consequências causadas in concretu pelo ato legislativo contrário aos preceitos constitucionais.

No mesmo sentido posiciona-se Rui Medeiros, in verbis:

A obrigação de indenizar por ilícito legislativo é, precisamente, um dos outros efeitos da inconstitucionalidade: não se trata já de impedir que a norma constitucional produza os efeitos jurídicos que lhe corresponderiam, mas de eliminar todos os danos que resultaram da vigência da lei na ordem jurídica ${ }^{228}$.

\footnotetext{
${ }^{226}$ Ana Paula Ávila, realizando ponderações acerca da constitucionalidade do artigo 27 da Lei no 9.868/99, conclui que haverá situações em que invalidar os efeitos da norma inconstitucional seria ainda mais contrário à Constituição do que mantê-los. Segundo a autora, deve-se analisar nessas situações não só as normas constitucionais que justificam a declaração de inconstitucionalidade da norma infraconstitucional, mas também se deve recorrer às normas constitucionais que tutelem/justifiquem a preservação dos efeitos produzidos por essa norma. Cf. ÁVILA, Ana Paula Oliveira. A modulação de efeitos temporais pelo STF no controle de constitucionalidade. Porto Alegre: Livraria do Advogado, 2009, pp. 69-70.

${ }^{227}$ ESTEVES, Júlio César dos Santos. Responsabilidade Civil do Estado por Ato Legislativo. Belo Horizonte: Del Rey, 2003, pp. 218-219.

${ }^{228}$ MEDEIROS, Rui. Ensaio sobre a responsabilidade civil do estado por actos legislativos. Coimbra: Almedina, 1992, p. 131.
} 
Prossegue o autor, afirmando que mesmo nos casos de declaração de inconstitucionalidade da lei com efeitos ex tunc, ou seja, ainda que ocorra a destruição dos efeitos jurídicos produzidos diretamente pela lei inconstitucional, não se consegue, porém, apagar os efeitos materiais danosos e, nessa medida, não se elimina o problema da responsabilidade civil do Estado pela aprovação de lei inconstitucional ${ }^{229}$.

Certo é que entre o ordenamento jurídico brasileiro e o ordenamento jurídico português encontram-se diferenças, principalmente porque no segundo está na própria Constituição a forma de regular as situações jurídicas decorrentes de lei declarada inconstitucional.

No Brasil, embora se admita a modulação dos efeitos da inconstitucionalidade pelo Supremo Tribunal Federal, nem a Constituição nem um diploma legal preveem qual deve ser o tratamento dispensado às diversas situações jurídicas realizadas durante a vigência da norma inconstitucional.

Isso influenciará, por certo, o tema da responsabilidade civil do Estado por lei inconstitucional, como se verá adiante. Trata-se, todavia, de uma questão ainda não estruturada pelo ordenamento jurídico brasileiro, sendo oportuno abordar, inclusive, como alguns ordenamentos estrangeiros têm enfrentado a questão. Vale, contudo, como início para um debate, instigando novos estudos no direito pátrio.

\subsection{Argumentos para a admissão da responsabilidade civil do Estado pelo desempenho inconstitucional da função legislativa}

Em matéria de responsabilidade, costuma-se compreender a lei inconstitucional como uma espécie de ato ilícito, ainda que a expressão possa parecer curiosa, conforme salienta César Viterbo Matos Santolim ${ }^{230}$.

Alguns autores chegam a afirmar que a lei, quando eivada de vício de inconstitucionalidade, perde o dom da legalidade, reduzindo-se ao patamar mesmo da ilicitude, isto é, sustenta-se que a lei inconstitucional não chega a ser propriamente um ato

${ }^{229}$ MEDEIROS, Rui. Ensaio sobre a responsabilidade civil do estado por actos legislativos. Coimbra: Almedina, 1992, p. 138.

${ }^{230}$ SANTOLIM, César Viterbo Matos. A responsabilidade civil do Estado por ato legislativo. Estudos Jurídicos, São Leopoldo (RS), n. 55, v. 22, pp. 44-54, 1989, p. 52 
legislativo, figurando na categoria de ato decorrente de mera atividade da Administração. Daí adotar-se para esses casos o regime da responsabilidade civil do Estado por atos administrativos, cujos princípios são largamente conhecidos ${ }^{231}$.

Para Rui Medeiros, no entanto, não se pode enquadrar corretamente as normas que regem a responsabilidade da Administração por atos de gestão pública ou privada no regime de responsabilidade dos atos legislativos, uma vez que a própria característica do órgão que elabora os atos legislativos, bem como as formalidades adotadas para sua preparação, os diferenciam dos atos administrativos e os colocam numa diferente posição hierárquica $^{232}$. Nem os casos em que a lei encerra um ato com características de individualidade - as chamadas leis-medida ou leis-individuais - permitiriam a completa invocação do regime dos atos administrativos para aqueles contidos em diploma legal ${ }^{233}$.

Tais posições fazem retomar a noção de lei abordada em passagem anterior. Conforme se concluiu, a lei, na experiência constitucional brasileira, é definida por seu regime jurídico e forma. Não é apenas o conteúdo que a define, como se ensaia na Alemanha $^{234}$, nem apenas a origem (ato proveniente do Poder Legislativo) e estrutura (contendo as características de generalidade, abstração e permanência), conforme se defende na França, que permitem a sua diferenciação perante os demais atos normativos praticados pelo Estado. Nem, ainda, o conteúdo dirigido à solução de uma questão concreta lhe retira o caráter de ato legislativo. A lei que contém tal traço reflete a busca de um conceito capaz de dar conta da atividade legislativa do Poder Público no Estado contemporâneo.

Admite Clèmerson Merlin Clève a legitimidade das leis-objetivo, ou seja, aquelas que buscam resolver circunstâncias concretas, sendo a um tempo lei e execução de lei. São atos que trazem, em seu universo, ao mesmo tempo, características da lei e do ato administrativo de cumprimento da lei ${ }^{235}$.

\footnotetext{
${ }^{231}$ FREITAS, Maria Helena D'Arbo Alves de. A responsabilidade civil do Estado por ato legislativo. Franca: UNESP - FHDSS, 2001, p. 46.

${ }^{232}$ MEDEIROS, Rui. Ensaio sobre a responsabilidade civil do Estado por actos legislativos. Coimbra: Almedina, 1992, p. 21.

${ }^{233}$ Ibidem, p. 21.

${ }^{234}$ CLÈVE, Clèmerson Merlin. A lei no Estado contemporâneo. Cadernos de Direito Constitucional $e$ Ciência Política. Revista dos Tribunais, São Paulo, n.21, pp. 124-138, out./dez. 1997, p. 128.

${ }^{235}$ Ibidem, p. 128.
} 
Nesse sentido, considerando todas essas características que estão associadas à acepção da lei, pode-se concluir que, quando há uma declaração de inconstitucionalidade da lei, não se pode equipará-la a mero ato administrativo e aplicar-se, integral e indistintamente, o regime de responsabilidade civil do Estado por atos administrativos. Isto não quer dizer, todavia, que o regime de responsabilidade por atos legislativos deva ser diferente do consagrado pela Constituição, pois é esta quem define - e não qualquer outra norma - o regime de responsabilidade por atos comissivos ou omissivos praticados pelo Estado.

O problema não deixa de ser, entretanto, de responsabilidade do Estado Legislador, pois a lei, ainda que no sentido formal, não deixa de ser um ato com características e procedimento próprios. Há que se ressaltar, outrossim, como forma de amparar tal posicionamento, o fato de que vigora no direito constitucional brasileiro o princípio da tipicidade dos atos legislativos, conforme disposto no artigo 59 da Constituição Federal. Não há distinção entre lei constitucional e inconstitucional, ou entre lei com conteúdo abstrato e genérico e lei com características individuais que permitam a aplicação de um regime jurídico diverso.

Assim, se a Constituição Federal não excepciona tais hipóteses, não caberia a adoção de critérios diferentes para o caso de lei com efeitos concretos ou de lei declarada inconstitucional diante dos demais diplomas legais. Seguramente que se deve considerar haver leis que contêm, a um mesmo tempo, lei e execução de lei. Aí sim até se poderia falar em responsabilidade por ato administrativo, muito embora as formalidades a que está sujeita a lei, ou seja, o seu regime diferenciado, não permita, ainda, uma completa subsunção desta ao tratamento dispensado aos atos administrativos.

Não é o que entende, entretanto, o STF, que desconsidera serem espécies normativas os atos emanados do Poder Legislativo que contêm efeitos concretos, os quais sequer ficam sujeitos à jurisdição do controle de constitucionalidade ${ }^{236}$.

\footnotetext{
${ }^{236}$ BRASIL. Supremo Tribunal Federal. Ementa: “Ação Direta de Inconstitucionalidade - Decreto Legislativo Estadual que sustou concorrência instaurada pelo Poder Público - ato materialmente administrativo - inviabilidade de seu exame em sede de controle normativo abstrato - não-conhecimento da ação direta quanto ao artigo $1^{\circ}$ do Decreto Legislativo $\mathrm{n}^{\circ}$ 2.841/92 (...). Pedido parcialmente conhecido". Ação Direta de Inconstitucionalidade n. 834-0 - Mato Grosso (Medida Liminar). Relator: Ministro Celso de Mello. Tribunal Pleno. Julgado em: 11.02.93. DJ 02.04.93. Disponível em: http://www.stf.jus.br/portal/inteiroTeor/obterInteiroTeor.asp?numero=834\&classe=ADI-MC. Acesso em: 19.12.09.
} 
Embora reconhecendo a possibilidade de responsabilização estatal, o Supremo se manifestou no sentido de que não se está propriamente diante de uma lei quando esta é declarada inconstitucional, conforme voto do Ministro Relator Cândido Mota Filho:

Uma vez praticado pelo poder público um ato prejudicial que se baseou em lei que não é lei, responde ele por suas consequiências. (STF, Recurso Extraordinário $\mathrm{n}^{\circ}$ 21.504, Relator Cândido Mota Filho, Julgado em 15.05.1957) ${ }^{237}$.

No tema da responsabilidade, no entanto, apropriada parece a posição adotada por José Joaquim Gomes Canotilho, que compreende somente ter relevância deslocar o problema para o terreno da responsabilidade da Administração se assim for mais fácil a justificação da pretensão ressarcitória do lesado, hipótese a ponderar, tanto mais que a maioria das legislações não aceita uma responsabilidade por fato das leis. No entanto, aceitar essa posição, segundo o autor, é contradizer outra já sustentada: ou se admite um regime de reparação por fato das leis, com base nos princípios materiais constitucionais, ou então não parece haver como justificar uma dualidade de critérios num ordenamento onde não se distingue entre leis gerais e individuais ${ }^{238}$.

Daí que uma lei, ainda que inconstitucional, não deixa de ser lei para se tornar ato administrativo, razão pela qual este é um problema da responsabilidade do Estado Legislador, embora, como já ressalvado, a responsabilidade estatal não deixe de ser unitária, pois o que há é uma divisão funcional do poder, exercida por órgãos diferentes, embora sujeitos ao mesmo artigo $37, \S 6^{\circ}$ da Constituição da República.

De qualquer modo, nota-se que de forma mais comum a doutrina tem aceitado a responsabilidade do Estado quando a situação pessoal dos indivíduos tenha sofrido agravo motivado pelo desempenho inconstitucional da função de legislar.

Bielsa afirma que a lei inconstitucional legitima a pretensão indenizatória porque, neste caso, "a responsabilidade resulta virtualmente"239.

Amaro Cavalcanti propugna que:

(...) declarada uma lei inválida ou inconstitucional por decisão judiciária, um dos efeitos da decisão deve ser logicamente o de obrigar a União, Estado ou Município, a reparar o dano causado ao indivíduo, cujo direito fora lesado - quer restituindo aquilo que indevidamente foi exigido do

\footnotetext{
${ }^{237}$ Revista Trimestral de Jurisprudência, Brasília, v. 2, pp. 121-123, jul./set.1957.

${ }^{238}$ CANOTILHO, José Joaquim Gomes. O problema da responsabilidade do Estado por actos lícitos. Coimbra: Almedina, 1974, pp. 155-156.

${ }^{239}$ BIELSA, Rafael. Derecho Administrativo. Tomo V. 6. ed. Buenos Aires: La Ley, 1966, p. 3.
} 
mesmo, como sucede nos casos de impostos, taxas ou multas inconstitucionais, quer satisfazendo-se os prejuízos provadamente sofridos pelo indivíduo com a execução da lei suposta. ${ }^{240 .}$

Ainda na doutrina brasileira, Themístocles Brandão Cavalcanti afirma que "a nulidade da lei ou de alguns de seus dispositivos, por violar garantias constitucionais, justifica a responsabilidade quando, de sua aplicação, resultar prejuízo patrimonial"241.

As decisões do Supremo Tribunal Federal também prestigiam essa mesma conclusão:

RESPONSABILIDADE CIVIL DO ESTADO - DECLARAÇÃO DE INCONSTITUCIONALIDADE. O Estado responde civilmente pelo dano causado em virtude de ato praticado com fundamento em lei declarada inconstitucional (Recurso Extraordinário $\mathrm{n}^{\circ}$ 8.889, Relator: Ministro Castro Nunes, Julgado em 19.06.1948) ${ }^{242}$

RESPONSABILIDADE CIVIL DO ESTADO - LEI INCONSTITUCIONAL - INDENIZAÇÃO. O Estado responde civilmente por danos causados aos particulares pelo desempenho inconstitucional da função de legislar. (Recurso Extraordinário $\mathrm{n}^{\circ}$ 153.464, Relator: Ministro Celso de Mello, Julgado em 02. 09.1992, DJ $16.09 .90)^{243}$

\section{ATO LEGISLATIVO - INCONSTITUCIONALIDADE}

RESPONSABILIDADE CIVIL DO ESTADO. Cabe responsabilidade civil pelo desempenho inconstitucional da função de legislar (Recurso Extraordinário $\mathrm{n}^{\mathrm{0}}$ 158.962, Relator: Ministro Celso de Mello, Julgado em 04.12.1992, DJ 18.12.1992) $)^{244}$

Criticando, contudo, o entendimento de que a lei inconstitucional possa gerar a responsabilização estatal, aduz Sérgio Cavalieri Filho que uma lei, ainda que inconstitucional, não pode, por si só, causar danos a ninguém enquanto permanecer no plano da abstração, já que depende sempre de um ato administrativo para ser aplicada. Daí que, segundo o autor, a responsabilidade sempre se relacionará ao ato administrativo e não será desencadeada pelo reconhecimento da inconstitucionalidade da $\mathrm{lei}^{245}$.

Todavia, parece acertado concluir com Júlio César dos Santos Esteves que a circunstância de intermediação, isto é, da prática de ato administrativo fiel ao comando legal e necessário à sua execução, decorrência do princípio da legalidade a que se

\footnotetext{
${ }^{240}$ CAVALCANTI, Amaro. Responsabilidade civil do Estado. v. II. Rio de Janeiro: Borsoi, 1957, p. 623.

${ }^{241}$ CAVALCANTI, Themístocles Brandão. Tratado de Direito Administrativo. Vol. 1. 5. ed. São Paulo - Rio de Janeiro: Livraria Freitas Bastos, 1955, p. 437.

${ }^{242}$ Revista de Direito Administrativo, Rio de Janeiro, v. 20, p. 42-45, 1950.

${ }^{243}$ Revista de Direito Administrativo, Rio de Janeiro, v. 189, p. 305-306, 1992.

${ }^{244}$ Revista de Direito Administrativo, Rio de Janeiro, v. 191, p. 175-177, 1993.

${ }^{245}$ CAVALIERI FILHO, Sergio. Programa de responsabilidade civil. 8. ed. São Paulo: Atlas, 2008, p. 265.
} 
subordina o administrador público, não desnatura, na hipótese de dano, a realidade de que a causa da lesão se situa na inconstitucionalidade da lei, originada, pois, no desempenho da função de legislar ${ }^{246}$.

Nesse sentido, mais uma vez afirma-se que se trata de hipótese de responsabilidade civil do Estado Legislador, sendo o ato administrativo o meio de concretização de um dano já proveniente do exercício da função legislativa: é a ilicitude da função legislativa, somada à ocorrência do dano, que funcionará como justificativa bastante para o dever de reparação $^{247}$.

A maioria dos autores defende, ainda, que na hipótese de responsabilidade do Estado por lei inconstitucional haveria a necessidade de prévia declaração desta inconstitucionalidade através do controle de constitucionalidade abstrato, por meio do qual o Judiciário declarasse de forma erga omnes a invalidade de lei perante a Constituição.

A declaração de inconstitucionalidade constituiria um prius indispensável da responsabilidade civil do Estado, de modo que enquanto não fosse reconhecida a inconstitucionalidade do ato pelos tribunais, o Estado seria irresponsável, já que milita a favor do dispositivo legal a presunção de constitucionalidade ${ }^{248}$.

Argumenta-se, também, que essa presunção de constitucionalidade somente poderia ser elidida pelo órgão com competência específica para a declaração de inconstitucionalidade, mediante a observância do quórum e demais formalidades estabelecidas nas leis regedoras do controle concentrado.

Yussef Said Cahali ${ }^{249}$ ressalta, inclusive, a resistência em admitir a possibilidade de o Estado ressarcir os danos advindos da lei declarada inconstitucional pelo critério difuso, posto que seria permitir a propositura de uma ação direta de indenização, com declaração incidente de inconstitucionalidade da lei, para reparação dos danos consequentes do ato legislativo que se pretende inconstitucional, buscando-se, na fase do conhecimento, um substituto da actio judicati.

\footnotetext{
${ }^{246}$ Cf. ESTEVES, Júlio César dos Santos. Responsabilidade civil do Estado por ato legislativo. Belo Horizonte: Del Rey, 2003, p. 221.

${ }^{247}$ Ibidem, p. 220.

${ }^{248}$ Cf. CRETELLA JÚNIOR, José. O Estado e a obrigação de indenizar. Rio de Janeiro: Forense, 1998, p. 148.

${ }^{249}$ CAHALI, Yussef Said. Responsabilidade civil do Estado. 3. ed. São Paulo: Revista dos Tribunais, 2007, p.533.
} 
Entretanto, sustenta o autor que não haveria necessidade da declaração de inconstitucionalidade ter sido proclamada anteriormente ao ajuizamento da ação indenizatória, bastando que o tenha sido no curso da lide, pelas vias próprias ${ }^{250}$.

Analisa-se, no próximo item, em que medida ainda é razoável exigir, face ao sistema de controle de constitucionalidade adotado hodiernamente no Brasil, bem como diante da possibilidade de responsabilização estatal em face de atos lícitos, a declaração prévia de inconstitucionalidade de uma lei através de controle abstrato para fins de responsabilização estatal.

\subsection{A necessidade de prévia declaração de inconstitucionalidade para fins de responsabilização do Estado pela edição de ato legislativo}

Como acima mencionado, modificações estão ocorrendo nas próprias posições adotadas pelo Supremo Tribunal Federal em relação ao controle de constitucionalidade das leis, embora certas questões ainda não estejam completamente decididas ${ }^{251}$.

Mesmo sem definição acerca do efeito da decisão de inconstitucionalidade proferida em sede de controle difuso ${ }^{252}$, o STF tem reconhecido que essa declaração quebra a presunção de constitucionalidade inerente à regra jurídica, circunstância, portanto, que parece afastar o entendimento de que a declaração de inconstitucionalidade para fins de responsabilidade é somente aquela proferida através do controle concentrado.

Formalidades no âmbito do controle concentrado têm sido reconhecidas como dispensáveis para fins de declaração da inconstitucionalidade. É o que se pode verificar da decisão proferida pela $2^{\mathrm{a}}$ Turma do STF no Agravo Regimental em Agravo de Instrumento $\mathrm{n}^{\mathrm{o}} 168.149^{253}$, cujo relato foi elaborado pelo Ministro Marco Aurélio, a seguir transcrita:

Versando a controvérsia sobre o ato normativo já declarado inconstitucional pelo guardião da Carta Política da República - o Supremo Tribunal Federal -, descabe o deslocamento previsto no artigo

\footnotetext{
${ }^{250}$ CAHALI, Yussef Said. Responsabilidade civil do Estado. 3. ed. São Paulo: Revista dos Tribunais, 2007, p. 533.

${ }^{251}$ Refere-se aqui a divergência de opiniões apresentada por ocasião do julgamento da Reclamação Constitucional $\mathrm{n}^{\circ} 4.335$, a qual se encontra, ainda, pendente de julgamento.

${ }^{252}$ Reclamação constitucional $n^{\circ} 4.335$.

253 Brasil. Supremo Tribunal Federal. AI-AgR 168.149. Relator Ministro Marco Aurélio. Julgado em 26.06.95. DJ de 4.8.1995. Disponível em: http://www.stf.jus.br/portal/inteiroTeor/obterInteiroTeor.asp?numero=168149\&classe=AI-AgR. Acesso em: 15.08.09.
} 
97 do referido Diploma maior. O julgamento de plano pelo órgão fracionado homenageia não só a racionalidade, como também implica interpretação teleológica do art. $97 \mathrm{em}$ comento, evitando a burocratização dos atos judiciais no que nefasta ao princípio da economia e da celeridade. A razão de ser do preceito está na necessidade de evitarse que órgãos fracionados apreciem, pela vez primeira, a pecha de inconstitucionalidade argüida em relação a um certo ato normativo.

Outra característica que se nota nos posicionamentos do STF diz respeito à extensão da decisão do plenário que declara a inconstitucionalidade da norma municipal a outras situações idênticas, provenientes de municípios distintos. O Tribunal tem considerado dispensável a submissão da questão ao Pleno do Tribunal no caso de modelos legais idênticos.

Seguindo essa orientação, o Ministro Maurício Corrêa, quando do julgamento do RE 228.844/SP ${ }^{254}$, no qual se discutia a legitimidade do IPTU progressivo cobrado pelo Município de São José do Rio Preto, no Estado de São Paulo, valeu-se de fundamento fixado pelo plenário do STF, em precedente oriundo do Estado de Minas Gerais, no sentido da inconstitucionalidade da lei do Município de Belo Horizonte, que havia instituído alíquota progressiva do IPTU.

Modificação relevante haverá, ainda, se for vencedora a posição adotada pelo Ministro Relator Gilmar Mendes na Reclamação Constitucional n 4.335, a qual resultará na equiparação dos efeitos da decisão de inconstitucionalidade proferida por meio do controle difuso ao controle concentrado ${ }^{255}$.

Nota-se, portanto, que os argumentos no sentido de que a declaração de inconstitucionalidade que possibilita o ressarcimento é somente aquela proferida em sede de controle concentrado, com a obediência a todas as formalidades e requisitos de quórum exigidos, mostram-se em dissonância com a própria orientação do Supremo Tribunal Federal, que passou a ter uma tendência mais flexível e menos burocrática para a declaração da incompatibilidade da lei com a Carta Política, sem, todavia, descuidar do zelo que requer tal questão.

\footnotetext{
254 Decisão Monocrática. RE 228.844/SP. Ministro Maurício Correa. Julgamento em 20/05/1999. DJ 16/06/1999. Disponível em: http://www.stf.jus.br/portal/jurisprudencia/listarJurisprudencia.asp?s1=((228844.NUME. OU 228844.DMS. )) NAO S.PRES.\&base=baseMonocraticas. Acesso em: 19/12/2009.

255 STF, Reclamação Constitucional no 4.335. Brasília, 16 a 20 de abril de 2007. Disponível em: http://www.stf.jus.br/arquivo/informativo/documento/informativo463.htm. Acesso em: 27.06.2009.
} 
Compreende-se, portanto, que é possível a declaração da inconstitucionalidade para que a responsabilização do Estado Legislador ocorra através do exercício do controle difuso, principalmente quando o STF já a tenha pronunciado em determinado caso ou quando a norma legal que se questiona for análoga a outra também já apreciada e reconhecida como em dissonância com o Diploma maior.

Cabe ressaltar, ainda, que a doutrina mais recente objeta à exigência de que a prévia declaração de inconstitucionalidade da lei ocorra através do controle concentrado para permitir a responsabilização estatal. Maurício Jorge Pereira da Mota pondera que, tendo o ordenamento jurídico brasileiro acolhido, ao lado do controle abstrato de constitucionalidade das leis, o controle difuso, o qual permite que qualquer magistrado afaste a aplicação da norma inconstitucional diante de um caso concreto, nada justifica que tal matéria de fato seja insindicável pelo juiz ordinário antes da referida declaração dos tribunais. Acrescenta o autor que, embora exista a presunção de constitucionalidade das leis - argumento no qual se baseia a doutrina brasileira para justificar a exigência de prévia declaração de inconstitucionalidade das leis pelos Tribunais - esta é uma presunção iuris tantum, ou seja, admite prova em contrário, que é exatamente o que se realiza no processo de conhecimento ${ }^{256}$. Também advogando a possibilidade de que a responsabilização estatal por lei inconstitucional decorra do exercício do controle incidental de constitucionalidade, observam-se as posições de Marisa Helena D’Arbo Alves de Freitas ${ }^{257}$, Júlio César dos Santos Esteves ${ }^{258}$ e Eliana Bueno de Miranda Santos ${ }^{259}$.

Pelo exposto, considerando, especificamente, a existência de duas modalidades de controle de constitucionalidade das leis no ordenamento jurídico pátrio, entende-se que não há justificativa jurídica suficiente para opor-se a possibilidade de que o particular proponha diretamente a ação de indenização requerendo, incidentalmente, a declaração de inconstitucionalidade da lei, haja vista que nada impede que o magistrado julgue a referida inconstitucionalidade e, em seguida, reconheça o direito do particular ao ressarcimento.

\footnotetext{
${ }^{256}$ Cf. Mota, Maurício Jorge Pereira da. Responsabilidade civil do Estado Legislador. Rio de Janeiro: Lumen Juris, 1999, p. 142.

${ }^{257}$ FREITAS, Marisa Helena D'Arbo Alves de. Responsabilidade do Estado por atos legislativos. Franca: Unesp - FHDSS, 2001,p. 103.

${ }^{258}$ ESTEVES, Júlio César dos Santos. Responsabilidade civil do Estado por atos legislativos. Belo Horizonte: Del Rey, 2003, pp.231-232.

${ }^{259}$ SANTOS, Eliana Bueno de Miranda. Responsabilidade civil do Estado por atos legislativos. São Paulo: SRS Editora, 2008, pp. 134-137.
} 
Entretanto, há que se dar um passo para trás na questão da responsabilidade do Estado Legislador e analisar, em face do ordenamento jurídico, se ainda é relevante verificar a inconstitucionalidade da lei para fins de fazer atuar o instituto da responsabilidade do Estado Legislador.

Como já registrado, a declaração de inconstitucionalidade com força obrigatória geral não destroi todos os efeitos gerados pela lei declarada inconstitucional, resulta possível, então, demandar-se indenização quando houver lesão da esfera juridicamente protegida do cidadão, para fins de garantia da própria supremacia da Constituição.

Essa possibilidade de responsabilização, todavia, não decorre de forma automática da declaração de inconstitucionalidade. Como pressuposto da aplicação do instituto, há a necessidade de averiguar-se a ocorrência do dano como critério apto a gerar e influir na quantificação da indenização, além de ser indispensável a existência do nexo causal que liga o dano à conduta estatal.

É nesse sentido que José Cretella Júnior afirma: “A lei inconstitucional (...), $\underline{\text { se }}$ causar danos, possibilita, sempre, aos prejudicados as providências jurídicas para que cessem os efeitos produzidos"260 (grifo nosso).

\title{
Maria Emília Mendes Alcântara também ressalta que:
}

\begin{abstract}
A só inconstitucionalidade da lei, a só desconformidade dela ao ordenamento jurídico não é suficiente para determinar a atuação do instituto da responsabilidade. Pode ocorrer que o ato legislativo inconstitucional produza lesão de direitos cujos efeitos não sejam patrimoniais; a sanção será neste caso a mera declaração de inconstitucionalidade ${ }^{261}$.
\end{abstract}

Canotilho, por sua vez, defende que pode haver ilegalidade sem que haja responsabilidade: no caso de a ilegalidade não ter provocado danos. No seu entendimento, o particular na referida situação terá direito à eliminação do ato viciado, mas não à reparação de danos. Isso porque a violação das normas emanadas no interesse público é insuficiente para fundamentar um pedido de indenização se, pelo menos, o fim dessa norma não for também o da defesa do lesado ${ }^{262}$.

\footnotetext{
${ }^{260}$ CRETELLA JUNIOR, José. Responsabilidade civil do Estado legislador. p. 181. In: CAHALI, Yussef Said (Coord). Responsabilidade civil: doutrina e jurisprudência. São Paulo: Saraiva, 1984, pp. 169-195.

${ }^{261}$ ALCÂNTARA, Maria Emília Mendes. Responsabilidade do Estado por atos legislativos e jurisdicionais. São Paulo: Revista dos Tribunais, 1988, pp. 66-67.

${ }^{262}$ CANOTILHO, José Joaquim Gomes. O problema da responsabilidade do Estado por actos lícitos. Coimbra: Almedina, 1974, p. 73.
} 
Segundo o entendimento do autor lusitano:

A violação dos preceitos jurídicos não é, por si só, fundamento bastante da responsabilidade. Quer se exija a violação de direitos subjetivos, quer a violação dum dever jurídico ou funcional para com o lesado, quer ainda uma falta da administração, faz-se intervir sempre um elemento qualificador e definidor de uma relação mais íntima do indivíduo prejudicado para com a administração do que a simples legalidade e regularidade do funcionamento dos órgãos administrativos ${ }^{263}$.

Entende-se apropriada a opinião do autor - já que está em consonância com o próprio conceito de responsabilidade - da qual se extrai a necessidade de ocorrência de uma lesão na esfera juridicamente protegida de outrem ${ }^{264}$, razão pela qual a incompatibilidade entre a lei e a Constituição não se mostra como condição suficiente para demandar indenização, especialmente porque tal incompatibilidade pode ser meramente formal, não causando prejuízo material a qualquer cidadão.

Controverso é, no entanto, saber quando se evidencia a ocorrência do dano, face às peculiaridades dos pressupostos que o caracterizam quando ele é decorrente de ato lícito ou ilícito.

Conforme já se argumentou em capítulo anterior, embora diante da consagração do princípio da divisão dos encargos públicos tenha ocorrido uma diminuição da importância da análise do tipo de conduta estatal, a diferença entre a consideração de um ato lícito ou ilícito ainda tem influência sobre os pressupostos que devem ser demonstrados pelo particular para gerar a responsabilidade do Estado, além de implicar também diferentes consequências para o Estado, principalmente diante da possibilidade de acionar-se o agente público de forma regressiva. Deste modo, a princípio, mostra-se relevante distinguir um ato legislativo constitucional - lícito - de um ato legislativo inconstitucional - ilícito - para fins de aplicação do instituto.

Vale lembrar que, no caso de atos administrativos ilícitos, bastaria ao particular provar que o ato atingiu uma situação jurídica legítima ou, ao menos, um interesse legítimo, e que o dano é certo e não eventual. Já no caso de atos administrativos lícitos, haveria a necessidade de que o particular provasse, além desses pressupostos, a especialidade e anormalidade do dano, para que assim esse fosse considerado passível de indenização.

\footnotetext{
${ }^{263}$ Ibidem, p. 75.

${ }^{264}$ MELLO, Celso Antonio Bandeira. Curso de Direito Administrativo. 26. ed. São Paulo: Malheiros, 2009, p. 1010.
} 
Se existem diferenças na configuração de um dano decorrente de ato administrativo ilícito e lícito, há que se questionar se elas também são aplicáveis quando se trata de atos legislativos que, no caso, seriam considerados inconstitucionais ou constitucionais.

Essa questão passa, necessariamente, sob a ótica do controle de constitucionalidade das leis, principalmente em relação aos efeitos produzidos com o reconhecimento da inconstitucionalidade, tema sobre o qual já se discorreu anteriormente e que, a esta altura, será relacionado com os pressupostos do dever de indenizar.

As posições que sustentam a necessidade de prévia declaração da inconstitucionalidade parecem derivar, na verdade, da facilidade de se observar a concretização do dano quando esse é decorrente de uma atitude ilícita do Estado, já que essa ilicitude, por infringir diretamente a ordem jurídica, revelaria a falha da função estatal, o mau funcionamento da função pública que caracteriza a culpa administrativa apta a fazer surgir, por parte do Estado, a obrigação de indenizar.

Assim, ao que parece, defender a necessidade da prévia declaração de inconstitucionalidade significa que o fundamento da responsabilidade do Estado neste caso estaria baseado na teoria do acidente administrativo, pela qual uma irregularidade anônima do serviço, no caso a inconstitucionalidade da lei, independentemente do comportamento culposo do agente, fundamentaria o dever estatal de indenizar.

É seguindo esta linha que Eliana Bueno de Miranda Santos defende não ser suficiente a comprovação do dano e do nexo de causalidade quando se trata de responsabilidade do Estado por atuação legislativa ilícita. Para a autora, além destes requisitos, seria necessário comprovar a ilegalidade ou inconstitucionalidade do ato normativo elaborado pelo Poder Legislativo, sem a qual não emerge ao Estado Legislador o dever de ressarcir os danos sofridos. Segundo o seu entendimento, o Estado Legislador responde por ato ilícito após a comprovação da ilegalidade do ato normativo, via declaração de inconstitucionalidade, prévia ou incidentalmente ${ }^{265}$.

265 SANTOS, Eliana Bueno de Miranda. Responsabilidade civil do Estado por atos legislativos. São Paulo: SRS Editora, 2008, pp. 142-143. 
Acrescenta que, quando um ato legislativo é declarado inconstitucional, todos os lesados têm direito ao ressarcimento, pois ninguém é obrigado a suportar um dano causado por ato ilegal, independentemente de sua natureza jurídica ${ }^{266}$.

Entretanto, tal consideração parece não corresponder à evolução do instituto da responsabilidade pública que busca se desvencilhar do modelo da culpa. A defesa da indispensabilidade da prévia declaração de inconstitucionalidade da lei para gerar o direito à indenização não se coaduna com a possibilidade atual do Estado ser responsabilizado, inclusive, por condutas lícitas, desde que preenchidos os pressupostos deste tipo de responsabilização.

Admite-se hoje na doutrina e jurisprudência que o direito à reparação abarca até condutas lícitas, sendo irrelevante demonstrar-se a ocorrência da faute de service, nem sequer quando se trate de ato ilícito.

Marisa Helena D’Arbo Alves de Freitas, contrapondo-se à necessidade de prévia declaração de inconstitucionalidade da lei para gerar o direito à indenização, sustenta que embora a situação de ilicitude do ato seja garantidora da reparação dos danos, o prejudicado tem, nesta situação, uma proteção menos eficaz do que a dada ao particular quando lesado por leis conformes aos preceitos constitucionais. Isso porque, nesse caso, caberia ainda ao autor comprovar previamente a invalidade do ato lesivo através de uma declaração proferida pelo tribunal de cúpula ou órgão especial, requisito este que não se faz necessário quando se trata de amparar a responsabilidade em bases objetivas ${ }^{267}$.

É pertinente a opinião da autora, já que, como se observa do disposto no artigo 103 da CF, há um rol específico de legitimados para propor a ação direta de inconstitucionalidade, o que dificulta, sobremaneira, a proteção jurídica que se confere aos direitos fundamentais através do instituto da responsabilidade estatal se este se encontra condicionado ao julgamento de inconstitucionalidade da lei pelo Poder Judiciário.

Ainda que se possa obter incidentalmente a declaração de inconstitucionalidade, a necessidade desta declaração prévia pode dificultar ou simplesmente atrasar o exame dos pressupostos necessários a fazer agir o instituto da responsabilidade estatal.

\footnotetext{
${ }^{266}$ Ibidem, p. 143.

${ }^{267}$ FREITAS, Marisa Helena D’Arbo Alves de. Responsabilidade do Estado por atos legislativos. Franca: UNESP - FHDSS, 2001, p. 103.
} 
Oportuno salientar a opinião de José Joaquim Gomes Canotilho ${ }^{268}$ sobre essa questão. O autor afirma que a pretensão indenizatória nunca pode assentar-se na culpa do órgão ou agente lesante, já que é possível, inclusive, submeter os casos de atos ilícitos ao regime da responsabilidade de atos lícitos. Quando se trata, especificamente, de atos legislativos, defende o autor que tal premissa é deveras importante, porque há países que não realizam o controle de constitucionalidade das leis.

Para o citado jurista, seria cabível a adoção do regime de responsabilidade civil por atos lícitos quando se trata de lei formalmente inconstitucional, em que, apesar de ter-se a declaração de inconstitucionalidade, não se identifica de pronto o dano. Em suas palavras:

\begin{abstract}
A violação das normas de competência ou de processo de formação das leis não é de per se um sacrifício grave e, por isso, não pode fundamentar autonomamente uma pretensão indemnizatória. Todavia, se porventura se constatar uma lesão grave e anormal da posição jurídica do cidadão, ocasionada por leis formalmente inconstitucionais, o fenômeno reparatório obedecerá aos mesmos princípios das leis constitucionais. Deverá reconhecer-se uma tutela ressarcitória quando os danos provocados por actos formal ou organicamente inconstitucionais foram de tal modo graves que eles seriam indemnizáveis mesmo no caso de serem impostos por actos irrefutavelmente válidos. Caso contrário, seria tratar mais desfavoravelmente os atos lícitos impositivos de sacrifícios de que os ilícitos, chegando-se ao resultado paradoxal de ser a inconstitucionalidade a justificar a irressarcibilidade. Concluímos, assim, que o carácter ilegal é, nestes casos, um elemento irrelevante: decisiva é apenas a imposição do sacrifício especial e grave, originador da ruptura da igualdade material. ${ }^{269}$
\end{abstract}

Na hipótese aventada, a prévia declaração de inconstitucionalidade não seria suficiente para comprovar a falha da função estatal geradora do dano, de modo que o particular lesado teria que demonstrar outras características do seu prejuízo para configurar o direito à indenização.

Não concorda Rui Medeiros integralmente com tal conclusão ${ }^{270}$. Para este outro autor português, embora a inconstitucionalidade formal não confira, por si só, qualquer interesse legítimo ao terceiro lesado, essa inconstitucionalidade pode ter como consequência a ofensa de um interesse protegido pela ordem jurídica e, nessa medida, constituir um fato ilícito.

\footnotetext{
${ }^{268}$ CANOTILHO, José Joaquim Gomes. O problema da responsabilidade do Estado por actos lícitos. Coimbra: Almedina, 1974, pp. 126 e 156 et seq.

${ }^{269}$ CANOTILHO, José Joaquim Gomes. O problema da responsabilidade do Estado por actos lícitos. Coimbra: Almedina, 1974, p. 158.

${ }^{270}$ MEDEIROS, Rui. Ensaio sobre a responsabilidade civil do Estado por actos legislativos. Coimbra: Almedina, 1992, pp. 169-172.
} 
Isso porque na avaliação que o autor faz do artigo $6^{\circ}$ do Decreto-Lei 48051, constante do referido ordenamento português, destaca que esse diploma legal chama a atenção para o fato de todas as normas jurídicas, incluindo as chamadas normas orgânicas e funcionais, interessarem (e muito) aos particulares e, por isso, haveria um fato ilícito sempre que a violação de uma norma orgânica ou formal tenha como consequência a lesão de um direito ou de uma disposição legal destinada a proteger os interesses do particular.

Ainda defendendo tal posicionamento, o autor recorre a uma análise do âmbito de abrangência do recurso cabível para o Tribunal Constitucional no ordenamento português, para defesa de interesses legítimos. Afirma o jurista que o recorrente poderá alegar qualquer inconstitucionalidade orgânica ou formal da lei para afastar a sua aplicação ao caso concreto. Deste modo, compreende que sempre que da inconstitucionalidade resulte a violação de qualquer direito subjetivo ou interesse legalmente protegido, quer seja tal vício material ou formal, haverá um fato ilícito, o qual configura, segundo o seu entendimento, um pressuposto apto para responsabilizar o Estado Legislador.

Para verificar como ocorre essa violação com a declaração da inconstitucionalidade formal da lei, propõe o citado autor a fórmula denominada causa virtual do dano. Tal procedimento levaria em conta a possibilidade de retroação da norma, ou seja, não haveria o dever de indenizar na hipótese em que o Estado detivesse a faculdade de imprimir, mediante a lei nova, e agora formalmente válida, os mesmos efeitos buscados com a lei invalidada. Neste sentido, a constitucionalidade ou inconstitucionalidade da lei não teria relevância para fundamentar o pedido de indenização ${ }^{271}$.

No Brasil, advogando que não é em todos os casos que a inconstitucionalidade da lei tem caráter relevante para verificação do dano, Maria Emília Mendes Alcântara ${ }^{272}$ expõe:

Acreditamos que para fins de indenização ao atingido por ato legislativo não cabe indagar da constitucionalidade ou não desse ato, mas apenas provar o dano e sua conexão direta e imediata com a atuação do Poder Legislativo.

Isto porque o direito à reparação não derivaria, em todos os casos, da inconstitucionalidade, mas sim do caráter lesivo do ato praticado pelo agente público.

${ }^{271}$ MEDEIROS, Rui. Ensaio sobre a responsabilidade civil do Estado por actos legislativos. Coimbra: Almedina, 1992, p. 173.

${ }_{272}$ ALCÂNTARA, Maria Emília Mendes. Responsabilidade do Estado por atos legislativos e jurisdicionais. São Paulo: RT, 1988, p. 66. 
E mais a frente explica:

O que se quer deixar patente é que a indenização, em certos casos, é devida independentemente do caráter lícito do ato e em outros casos ela só é possível por se tratar de ato inconstitucional. Na primeira hipótese há que se provar a especialidade e a anormalidade do dano, na segunda essas características já decorrem do próprio ato inconstitucional. ${ }^{273}$

Observa-se, pelo exposto, que o foco é o dano advindo da conduta legislativa, de modo que quando esta fosse inconstitucional, em alguns casos, principalmente nos quais se tratasse da inconstitucionalidade material da lei, a declaração apenas facilitaria a demonstração da especialidade e da anormalidade do dano, dispensando-se o particular de sua prova. Tal não significa, entretanto, que haveria sempre a necessidade deste controle prévio, já que quando o particular demonstrasse as características especiais e anormais do prejuízo, independentemente do controle da constitucionalidade, não haveria que se indagar acerca da licitude ou ilicitude do ato legislativo.

Pode-se concluir, assim, que se por um lado é dispensável a exigência de prévia declaração da inconstitucionalidade da lei para se pleitear o direito à indenização, por outro, quando essa incompatibilidade não tiver sido apreciada pelos tribunais, de forma geral ou incidental, segue-se o regime da responsabilidade por atos lícitos, que exige, por certo, além da demonstração da infringência de uma situação jurídica legítima ou, ao menos, de um interesse legítimo, juntamente com a comprovação de um prejuízo certo e a demonstração da especialidade e anormalidade do dano. Tais características não prescindem de demonstração, contudo, caso se esteja diante de uma inconstitucionalidade formal que não possa ser sanada mediante a edição de uma lei nova, posto que nessas situações haverá uma afronta à ordem jurídica, um ilícito que serve de fundamento para a responsabilidade civil estatal.

2.2.1.3. A limitação da responsabilidade civil estatal em razão da modulação dos efeitos da inconstitucionalidade

Como visto anteriormente, no Brasil admite-se que o Supremo Tribunal Federal possa modular os efeitos da declaração de inconstitucionalidade de uma lei, sendo que tal entendimento já era praticado pela Egrégia Corte anteriormente ao advento da Lei 9.868/99, cujo artigo 27 veio permitir expressamente a atribuição, excepcional, de efeitos à

${ }^{273}$ Ibidem, p. 68. 
referida declaração a partir do trânsito em julgado da sentença, ou de outro momento que nesta venha a ser fixado.

Ocorre, então, que quando o Supremo Tribunal Federal declara a inconstitucionalidade da lei com efeitos ex nunc ou ainda pro futuro, inúmeras situações jurídicas que se estabeleceram durante a vigência dessa lei e que ainda irão se assentar quando uma inconstitucionalidade apenas opera num prazo futuro - devem ser mantidas. Sem adentrar no aspecto relativo à constitucionalidade dessa modulação de efeitos, uma vez que o referido artigo é hoje objeto de ação direta de inconstitucionalidade ${ }^{274}$, é fato que o STF tem aplicado o referido dispositivo, modulando os efeitos da inconstitucionalidade de uma lei, invocando razões de segurança jurídica, como observa Ana Paula Oliveira Ávila, conjugadas a argumentos de que o entendimento de modo contrário conduziria à acefalia do ente estatal, a não proteção do acesso à jurisdição ${ }^{275}$.

Caberia, portanto, questionar se haveria responsabilidade civil do Estado mesmo tendo havido a declaração de inconstitucionalidade de uma lei cujos efeitos irão operar apenas a partir de tal reconhecimento, ou em momento posterior.

O problema ainda não foi apreciado pelos tribunais pátrios como uma questão relativa à responsabilidade civil do Estado Legislador, embora a Suprema Corte já tenha se pronunciado expressamente no sentido de que, ausente a previsão de modulação de efeitos, é de se considerar que tal equivale à decisão de retroatividade irrestrita, ou seja, ex tunc, o que, por exemplo, arremete à necessidade de repetição dos valores pagos indevidamente pelo contribuinte com base em lei inconstitucional. Nessa direção, o Agravo Regimental no Recurso Extraordinário no 392.139/RJ, Relator Ministro Eros Grau, cuja ementa se transcreve:

Agravo regimental em Recurso Extraordinário. IPTU. Alíquota progressiva. Declaração de inconstitucionalidade com eficácia

\footnotetext{
${ }^{274}$ Cf. duas ações diretas de inconstitucionalidade (ADIN n ${ }^{\circ}$ 2154-2 e ADIN no 2258-0, Relator: Ministro Sepúlveda Pertence para ambas, ainda pendentes de julgamento).

${ }^{275}$ A autora cita como exemplo dessas situações o RE n ${ }^{\circ}$ 197.917-8. Relator: Min. Maurício Corrêa, de 6 de junho de 2002, decisão em que ocorreu a modulação dos efeitos da inconstitucionalidade (efeitos para o futuro) para preservar os atos já praticados pela Câmara Municipal e garantir a continuidade de sua existência até o final do mandato de vereadores, tempo que deveria ser aprovada nova lei que respeitasse a proporcionalidade estabelecida pela Constituição e o número de vereadores. Menciona também a $\operatorname{ADIN~} \mathrm{n}^{\circ}$ 3.022-1/RS. Relator: Min. Joaquim Barbosa, de 2 de agosto de 2004, no qual houve a declaração de inconstitucionalidade da alínea $a$ do Anexo II da Lei Complementar no 10.194/94, com eficácia pro futuro tendo em vista a necessidade de assegurar, em casos concretos, individualmente, a prestação da assistência jurídica pelo Estado aos hipossuficientes. Cf. ÁVILA, Ana Paula Oliveira. A modulação de efeitos temporais pelo STF no controle de constitucionalidade. Porto Alegre: Livraria do Advogado, 2009, pp. 104-110.
} 
prospectiva [ex nunc] em sede de controle difuso. Não configuração dos requisitos previstos no artigo 27 da lei n. 9.868/99. 1. A possibilidade de atribuir-se efeitos prospectivos à declaração de inconstitucionalidade, dado o seu caráter excepcional, somente tem cabimento quando o Tribunal manifesta-se expressamente sobre o tema, observando-se a exigência de quórum qualificado previsto em lei específica. 2. Em diversas oportunidades, anteriormente ao advento da emenda constitucional n. 29/00, o Tribunal, inclusive em sua composição plenária, declarou a inconstitucionalidade de textos normativos editados por diversos municípios em que se previa a cobrança do IPTU com base em alíquotas progressivas. Em nenhuma delas, entretanto, reconheceu-se a existência das razões de segurança jurídica, boa-fé e excepcional interesse social, ora invocadas pelo agravante, para atribuir eficácia prospectiva àquelas decisões. Pelo contrário, a jurisprudência da Corte é firme em reconhecer a inconstitucionalidade retroativa dos preceitos atacados, impondo-se, conseqüentemente, a repetição dos valores pagos indevidamente. Agravo regimental a que se nega provimento ${ }^{276}$.

No direito estrangeiro, observam-se algumas situações em que o tema foi abordado pela doutrina e jurisprudência. No entanto, como se verá adiante, não há uma solução unívoca, havendo posições ora favoráveis à admissão da responsabilidade, ora contrárias. Daí revestir-se de interesse o estudo desse tema em outros países - especialmente dos que descendem da mesma base romanística - sem a pretensão, contudo, de realizar um estudo de direito comparado. Interessa conhecer algumas luzes que começam a iluminar o assunto e, por isso, será feita uma breve incursão sobre as situações suscitadas no ordenamento português e espanhol.

\subsection{A posição de Rui Medeiros em face do ordenamento jurídico português}

Em Portugal, os efeitos da declaração de inconstitucionalidade de uma lei podem também ser modulados pelo Tribunal Constitucional, por força do que dispõe o artigo 282 da Constituição Portuguesa, in verbis:

Artigo 282. ${ }^{\circ}$ - (Efeitos da declaração de inconstitucionalidade ou de ilegalidade)

1.A declaração de inconstitucionalidade ou de ilegalidade com força obrigatória geral produz efeitos desde a entrada em vigor da norma declarada inconstitucional ou ilegal e determina a repristinação das normas que ela, eventualmente, haja revogado.

2.Tratando-se, porém, de inconstitucionalidade ou de ilegalidade por infracção de norma constitucional ou legal posterior, a declaração só produz efeitos desde a entrada em vigor desta última.

276 Julgado em 26.04.05. DJ 13.05.05. Disponível em:

http://www.stf.jus.br/portal/inteiroTeor/obterInteiroTeor.asp?numero=392139\&classe=RE-AgR. Acesso em: 20 out. 2009. 
3.Ficam ressalvados os casos julgados, salvo decisão em contrário do Tribunal Constitucional quando a norma respeitar a matéria penal, disciplinar ou de ilícito de mera ordenação social e for de conteúdo menos favorável ao arguido.

4.Quando a segurança jurídica, razões de equidade ou interesse público de excepcional relevo, que deverá ser fundamentado, o exigirem, poderá o Tribunal Constitucional fixar os efeitos da inconstitucionalidade ou da ilegalidade com alcance mais restrito do que o previsto nos $n^{\text {os }} 1$ e 2 .

Observa-se que, regra geral, os efeitos da inconstitucionalidade operam desde a entrada em vigor da norma no ordenamento (ressalva feita aos casos em que ocorre inconstitucionalidade posterior). Ainda que a inconstitucionalidade tenha sido declarada com efeitos ex tunc, respeitam-se os casos julgados, salvo decisão em contrário pronunciada pelo Tribunal Constitucional. Ocorre, no entanto, excepcionalmente, a possibilidade de modulação dos efeitos da inconstitucionalidade, quando razões de segurança jurídica, equidade ou interesse público de excepcional relevo assim exigirem.

Rui Medeiros, doutrinador português, em trabalho que analisou a responsabilidade civil do Estado por atos legislativos, observa que há situações jurídicas que devem ser mantidas a despeito da declaração da inconstitucionalidade da lei com efeitos ex tunc, o que não levaria, no entanto, à inadmissibilidade do direito à indenização.

Para o autor ${ }^{277}$, mais do que as situações consolidadas através de uma decisão judicial que transita em julgado e põe termo a uma questão controvertida, também os atos administrativos baseados em lei inconstitucional podem ser meramente anuláveis e, nesses casos, consolidam-se com o decurso do tempo, de modo que devem ficar salvaguardadas da eventual declaração de inconstitucionalidade com efeitos retroativos ${ }^{278}$. Segundo o autor:

Parte da doutrina portuguesa admite, timidamente, que a retroactividade não atinja as relações consolidadas, designadamente as situações de facto ou de direito que se encontram defintivamente encerradas, porque se verificou a prescrição ou a caducidade do direito, cuja existência parecia incompatível com uma lei inconstitucional, porque o acto administrativo, que aplicava uma lei contrária à Constituição, se "sanou", porque um particular cumpriu uma obrigação, imposta por uma norma inconstitucional

\footnotetext{
277 MEDEIROS, Rui. Ensaio sobre a responsabilidade civil do Estado por actos legislativos. Coimbra: Almedina, 1992, p. 148.

278 Nas palavras do citado autor: "Por outro lado, mesmo que se admita que a nulidade dos actos administrativos pode derivar da natureza das coisas, não se deve ignorar que a necessidade de rodear de certeza e segurança as situações jurídicas criadas no desempenho da função administrativa torna indiscutível a preferência pelo instrumento técnico da anulabilidade”. Ibidem, p. 152.
} 
A eventual retroatividade da declaração da inconstitucionalidade não atingiria tais casos, mas apenas as causas pendentes, isto é, a extensão da decisão de inconstitucionalidade alcançaria os fatos passados, mas se deteria perante as causas finalizadas, ou seja, respeitaria as decisões judiciais passadas em julgado e as causas exauridas (relações definitivamente consolidadas, em razão da prescrição, caducidade ou porque o particular cumpriu uma obrigação).

Todavia, mesmo nessas hipóteses em que caberia o respeito a tais situações jurídicas, ainda assim subsistiria a possibilidade de pleitear-se indenização no entendimento do referido doutrinador. Propugna que, no tocante aos atos administrativos que aplicaram a lei, diante do disposto no artigo $7^{\circ}$ do DL $48051 / 67^{279}$, é possível que o lesado pleiteie o ressarcimento dos danos que sofreu, "desde que tal dano não se possa imputar à não interposição do recurso contencioso" 280 - ou seja, desde que o lesado não tenha agido com culpa para a ocorrência do evento danoso. Assim, "o direito de indemnização, efeito secundário da inconstitucionalidade, não é posto em causa nos casos em que a lei inválida produz os seus efeitos principais"281 282.

Para a hipótese, o autor cita o exemplo de um particular que, agindo de boa-fé, efetua uma prestação porque uma lei (inconstitucional) o obriga a realizá-la, sendo que apenas posteriormente a lei é declarada inconstitucional pelo Tribunal Constitucional.

Nos termos propostos, aquele que efetua a prestação pode lançar mão do instituto do enriquecimento sem causa e obter a restituição daquilo que prestou indevidamente em face daquele que o recebeu. Mas a restituição do indevido não destroi os danos suportados por aquele que cumpriu a obrigação fundada na lei inválida, designadamente os provocados pela falta de disponibilidade do bem. Caberia aí a responsabilidade do Estado Legislador, desde que comprovado, nos termos do direito português, a prática de um ato legislativo ilícito e culposo que, nesse caso, não se confunde com a prestação. Mesmo que

\footnotetext{
${ }^{279}$ Explica Rui Medeiros que o artigo $7^{\circ}$ do DL 48057 consagra o princípio geral de que o dever de indenizar do Estado não depende do exercício, pelo lesado, do direito de recorrer do ato causador do dano, desde que tal dano não se possa imputar à não interposição do recurso contencioso. Ibidem, p. 153.

${ }^{280}$ MEDEIROS, Rui. Ensaio sobre a responsabilidade civil do Estado por actos legislativos. Coimbra: Almedina, 1992, p. 153.

${ }^{281}$ Ibidem, p. 154.

${ }^{282} \mathrm{O}$ autor cita como exemplo: "A manutenção de dever de indemnizar é ainda mais flagrante quando a ressalva dos efeitos produzidos pela lei inconstitucional visa impedir a invalidação dos actos administrativos nela baseados. Assim, por exemplo, do facto de as penas disciplinares impostas ao pessoal civil dos estabelecimentos fabris das forças armadas, ao abrigo de um decreto-lei formalmente inconstitucional, não poderem ser anuladas não decorre a impossibilidade de o lesado exigir uma indemnização do Estado pelo ilícito legislativo". Ibidem, p. 157.
} 
não houvesse a obrigação de restituir, aplicando-se o respeito pela situação jurídica consolidada, subsistiria o direito à indenização em face do Estado Legislador, uma vez que o dano provocado não se confunde com a prestação ${ }^{283}$.

De forma análoga à acima citada, Rui Medeiros trata da manutenção do dever de indenizar ainda que a declaração de inconstitucionalidade tenha efeitos ex nunc, ou seja, nos casos em que todas as situações anteriores à declaração foram firmadas. Daí que a manutenção dessas situações não impede o lesado de exigir uma indenização do Estado pelo ilícito legislativo ${ }^{284}$.

Ocorre que, para defender tal posicionamento, o autor parte da ideia de que a indenização e a reconstituição do direito são noções absolutamente autônomas. Para o doutrinador, após a anulação do ato ilegal, deve o Estado ordenar e efetuar a restituição da coisa requisitada, outorgar a licença ilegalmente rejeitada, conceder, nos termos da lei, a isenção de certo tributo, restituindo as somas recebidas, sendo que esses atos não consistem indenização, mas sim uma forma de execução da obrigação, de reconstituição do direito $^{285}$. Haveria autonomia para a propositura da ação de reparação de danos que, no caso da lei inconstitucional, seria uma ação apresentada em face do Estado Legislador e compreenderia os danos resultantes da não utilização da coisa ou bem, requisitados ou expropriados ao abrigo de uma lei inconstitucional.

Com a devida vênia, entende-se que a responsabilidade civil não está desvinculada da noção de reconstituição do direito, posto que essa reconstituição in natura inclui-se na própria função reparadora da responsabilidade civil que, todavia, é menos praticada, dadas as dificuldades da realidade da vida ${ }^{286}$.

Como já visto no capítulo 1 da primeira parte deste trabalho, a responsabilidade civil está ligada à ocorrência de um evento anterior, uma violação a um dever jurídico, buscando-se através dela a restituição do lesado ao estado em que se encontraria caso não tivesse havido a lesão. É função da responsabilidade civil, portanto, repor a vítima na

\footnotetext{
${ }^{283}$ Ibidem, pp. 154-155.

${ }^{284}$ Ibidem, p. 157.

${ }^{285}$ Cf. MEDEIROS, Rui. Ensaio sobre a responsabilidade civil do Estado por actos legislativos. Coimbra: Almedina, 1992, p. 140 et seq.

${ }^{286}$ Cf. DIAS, José de Aguiar. Da responsabilidade civil. 11. ed. Rio de Janeiro: Renovar, 2006, p. 986.
} 
situação anterior à lesão, de modo que opera neste campo o princípio da restitutio in integrum $^{287}$.

Daí que a reparação pode ser efetuada de duas formas: a primeira é por meio do ressarcimento, que consiste na compensação de uma soma pecuniária equivalente ao dano perpetrado. Consiste na composição em dinheiro, apurada mediante a estimativa das perdas e danos. A outra forma é por meio da reparação específica, ou in natura, que se concretiza com a restituição do sujeito ao estado anterior ao dano.

A reparação específica, como ensina José de Aguiar Dias, corresponde melhor ao fim de restaurar, mas a indenização em dinheiro legitima-se, subsidiariamente, pela consideração de que o dano patrimonial acarreta diminuição do patrimônio, e este é um conceito aritmético $^{288}$.

No direito brasileiro, dispõe o artigo 947 do Código Civil, que prejudicada a reposição das coisas no seu estado anterior, restará, subsidiariamente, a opção da reparação em dinheiro. Trata-se de norma que, embora assentada no referido Código, que rege as situações entre particulares, não deixa de ter caráter geral no que tange ao tema da responsabilidade civil.

No âmbito da responsabilidade civil estatal, visualiza-se também a possibilidade de reparação in natura. Observa-se que normalmente a declaração de inconstitucionalidade de uma lei com efeitos ex tunc gera para o particular a possibilidade, por exemplo, de repetir o indébito, o que configura, ao que se entende, a realização do próprio direito do particular de não ter o patrimônio afetado irregularmente, constituindo-se numa reparação pelo dano sofrido, muito embora, nessa situação, nem sempre se vislumbre a concretização da responsabilidade civil do Estado Legislador, haja vista que o pagamento será efetuado pela entidade arrecadadora que, através de ato administrativo, aplicou a lei, o Poder Executivo.

Não deixa de existir, contudo, a responsabilização civil do Estado, uma vez que deverá efetuar a restituição do valor do tributo atualizado e corrigido monetariamente. No caso da restituição não consistir em reparação integral do dano - circunstância que deverá ser devidamente comprovada pelo prejudicado -, subsiste, ainda, o direito de promover

\footnotetext{
${ }^{287}$ CAVALIERI FILHO, Sérgio. Programa de responsabilidade civil. 8. ed. São Paulo: Atlas, 2008, p. 13.

${ }^{288}$ DIAS, José de Aguiar. Op. cit., p. 985.
} 
ação em face do Estado, já que, como pondera Sérgio Cavalieri Filho, indenizar pela metade é responsabilizar a vítima pelo resto ${ }^{289}$.

\subsection{A posição de Eduardo García de Enterría em face do ordenamento jurídico espanhol}

Oportuno também conhecer o que na Espanha tem sido debatido sobre o assunto, uma vez que nesse país situações jurídicas firmadas com força de coisa julgada foram, posteriormente, desconstituídas através da responsabilização estatal em virtude da declaração de inconstitucionalidade da lei que havia servido de fundamento para pronúncia da decisão.

Inicialmente, cabe salientar que, na Espanha, a Constituição de 1978 estabelece um sistema de controle de constitucionalidade das leis, conferindo ao Tribunal Constitucional a competência para conhecer e julgar os recursos de inconstitucionalidade contra leis e disposições normativas com força de $1 \mathrm{e}^{290}$. No artigo 161.1, alínea "a", a Carta Constitucional espanhola prescreve que a declaração de inconstitucionalidade de uma norma jurídica com força de lei, interpretada pela jurisprudência, afeta a mesma, embora a sentença ou as sentenças não percam a força de coisa julgada.

Já o artigo 40.1 da Lei Orgânica do Tribunal Constitucional complementa que as sentenças declaratórias da inconstitucionalidade das leis não permitirão revisar processos terminados com força de coisa julgada nos quais tenha ocorrido a aplicação dessas leis, disposições ou atos inconstitucionais, salvo nos casos de processos penais ou de contencioso administrativo referentes a um procedimento sancionador, no qual, como consequência da nulidade da norma aplicada, resulte uma redução da pena ou da sanção ou uma exclusão, isenção ou limitação da responsabilidade ${ }^{291}$.

\footnotetext{
${ }^{289}$ CAVALIERI FILHO, Sérgio. Programa de responsabilidade civil. 8. ed. São Paulo: Atlas, 2008, p. 13.

290 Constituição Espanhola de 1978. Constitución Española de 1978: “Artículo 161. El Tribunal Constitucional tiene jurisdicción en todo el territorio español y es competente para conocer: a) Del recurso de inconstitucionalidad contra leyes y disposiciones normativas con fuerza de ley. La declaración de inconstitucionalidad de una norma jurídica con rango de ley, interpretada por la jurisprudencia, afectará a ésta, si bien la sentencia o sentencias recaídas no perderán el valor de cosa juzgada". Disponível em: http://narros.congresso.es.constitucion/constitucion/indice/articulos.jsp?ini=159\&fin=165\&tipo=2. Acesso em 24.06.09.

${ }^{291}$ ESPANHA. Tribunal Constitucional. LEY ORGÁNICA 2/1979, DE 3 DE OCTUBRE, DEL TRIBUNAL CONSTITUCIONAL. Texto consolidado e integrado con las modificaciones introducidas por las Leyes Orgánicas 8/1984, 4/1985, 6/1988, 7/1999 y 1/2000 y con expresión particularizada de las reformas conforme a la Ley Orgánica 6/2007, de 24 de mayo. "Artículo cuarenta. 1. Las sentencias declaratorias de la
} 
Não resta estabelecido na Carta Política se a declaração de inconstitucionalidade de uma lei deve operar sempre com efeitos ex tunc ou ex nunc. Todavia, Eduardo García de Enterría apresenta em sua obra precedentes jurisprudenciais e posições doutrinárias que confirmam que, a partir da Sentença 45/1989, o Tribunal Constitucional espanhol passou a reconhecer que lhe cabe decidir em cada caso quais os efeitos das sentenças que proferir ${ }^{292}$.

A responsabilidade do Estado Legislador no ordenamento espanhol em razão do reconhecimento da inconstitucionalidade de uma lei, a partir do ano 2000, ganhou fôlego para ser amplamente reconhecida pelo Tribunal Supremo.

Em 1996, através da Sentença $173 / 1996^{293}$, de 31 de outubro, o Tribunal Constitucional espanhol reconheceu a inconstitucionalidade de uma lei que havia estabelecido um encargo fiscal complementar sobre as máquinas de jogo, cujo pagamento havia sido efetuado por seus respectivos proprietários no ano de 1990. A sentença não delimitou, porém, os efeitos da declaração de inconstitucionalidade.

A partir disso, generalizaram-se os pedidos de devolução do mencionado tributo, ao que foi reconhecido pelo Tribunal Supremo como uma espécie de ação para

inconstitucionalidad de Leyes, disposiciones o actos con fuerza de Ley no permitirán revisar procesos fenecidos mediante sentencia con fuerza de cosa juzgada en los que se haya hecho aplicación de las Leyes, disposiciones o actos inconstitucionales, salvo en el caso de los procesos penales o contenciosoadministrativos referentes a un procedimiento sancionador en que, como consecuencia de la nulidad de la norma aplicada, resulte una reducción de la pena o de la sanción o una exclusión, exención o limitación de la responsabilidad". Disponível

http://85.62.99.51/es/tribunal/normasreguladoras/Lists/NormasRegPDF/Normas\%20Reguladoras/leyorgtrib.p df. Acesso em 24.06.09.

${ }^{292}$ ENTERRÍA, Eduardo García de. La responsabilidad patrimonial del Estado Legislador en el Derecho español. 2. ed. Navarra: Civitas, 2007, p. 242.

${ }^{293}$ ESPANHA. Tribunal Constitucional. Sentença 173 de 31 de outubro de 1996. PLENO. SENTENCIA 173/1996, DE 31 DE OCTUBRE DE 1996. CUESTIONES DE INCONSTITUCIONALIDAD 3.563/1993, 3.564/1993, 3.565/1993 Y 100/1994 (ACUMULADAS). EN RELACION, LAS TRES PRIMERAS, CON EL ART. 38.2.2 DE LA LEY 5/1990, DE MEDIDAS URGENTES EN MATERIA PRESUPUESTARIA, FINANCIERA Y TRIBUTARIA, QUE CREO UN GRAVAMEN COMPLEMENTARIO DE LA TASA FISCAL SOBRE LOS JUEGOS DE SUERTE, ENVITE O AZAR PARA EL AÑO 1990, Y CON EL APARTADO A), A), DEL NUM. 2 DEL ART. 3.4, DEL REAL DECRETO-LEY 16/1977, POR EL QUE SE REGULAN LOS ASPECTOS PENALES, ADMINISTRATIVOS Y FISCALES DE LOS JUEGOS DE SUERTE, ENVITE O AZAR Y APUESTAS, SEGUN LA NUEVA REDACCION DADA A DICHO PRECEPTO POR EL ART. 38.2.1 DE LA CITADA LEY 5/1990, Y LA CUARTA EN RELACION CON EL ART. 38.2.2 DE LA LEY 5/1990. Relatores: Fernando García-Mon y González-Regueral. BOE 03/12/1996. Disponível

em: http://www.boe.es/aeboe/consultas/bases_datos/doc.php?coleccion=iberlex\&id=1996/27188. Acesso em 24.06.09. 
responsabilização do Estado Legislador, obrigando-se a devolução pelo Estado das quantias pagas, incrementadas de juros legais ${ }^{294}$.

Embora conste expressamente no ordenamento espanhol que a declaração de inconstitucionalidade de uma lei deve respeitar a coisa julgada, conforme disposto no artigo 161.1, alínea "a", da Constituição, e artigo 40.1, da Lei Orgânica do Tribunal Constitucional, a posição do Tribunal Supremo em relação à declaração de inconstitucionalidade da lei feita pelo Tribunal Constitucional é a de que o exercício da ação de responsabilidade patrimonial do Estado Legislador é alheia ao âmbito da coisa julgada, de modo que mesmo nos casos em que já havia sido proferida uma decisão que transitou em julgado, na qual houve a aplicação da lei considerada inconstitucional (posteriormente) e que obrigou a parte ao pagamento do tributo, seria possível propor a referida ação de indenização e obter provimento, como se observa do disposto nas sentenças de 20 de janeiro de 2001 e 29 de janeiro de 2000, respectivamente:

No nosso sistema legal, quem teve que satisfazer o encargo
complementar imposto pelo preceito declarado inconstitucional, depois
de haver impugnado na via administrativa e em sede jurisdicional dito
ônus obtendo sentença firme que o declarou conforme ao direito, não tem
outra alternativa, em virtude do disposto no artigo 40.1 da Lei Orgânica
$2 / 1979$ do Tribunal Constitucional, do que exercer, como nesse caso
procedeu a entidade demandante, uma ação de responsabilidade
patrimonial derivada do ato do Legislador, dentro do prazo fixado pela
Lei. ${ }^{295}$ (tradução livre)

${ }^{294}$ Eduardo García de Enterría cita as seguintes sentenças, proferidas no ano de 2000 pelo Tribunal Supremo da Espanha, que reconheceram a responsabilidade patrimonial do Estado: de 13 de junho, de 15 de julho, de 30 de setembro, de 6 de novembro, de 14 de dezembro (duas sentenças), 19 de dezembro, 22 de dezembro, 23 de dezembro, (duas sentenças), 27 de dezembro (duas sentenças). No ano de 2001, enumera as sentenças de 11 de janeiro (duas sentenças), 16 de janeiro (duas sentenças), 20 de janeiro (duas sentenças), 22 de janeiro (duas sentenças), 23 de janeiro (duas sentenças), 25 de janeiro, 30 de janeiro, 3 de fevereiro, 5 de fevereiro, 8 de fevereiro, 13 de fevereiro, 17 de fevereiro, 19 de fevereiro, 20 de fevereiro (três sentenças), 22 de fevereiro, 2 de março, 3 de março (duas sentenças), 13 de março, 20 de março, 27 de março (duas sentenças), 7 de abril, 18 de abril (duas sentenças), 24 de abril, 12 de junho, 3 de julho, 5 de julho (duas sentenças), 17 de julho, 3 de outubro, 18 de outubro, 25 de outubro, 27 de outubro, 22 de dezembro (três sentenças). Em 2002, as sentenças de 24 de janeiro, 22 de janeiro (duas sentenças), 20 de fevereiro (duas sentenças), 18 de abril. Em 2003, diminuíram-se os números, tendo sido proferidas as seguintes: 4 de março, 13 de maio, 17 de junho, 1 de julho, 3 de julho (duas sentenças), 8 de julho, 15 de julho (duas sentenças). Em 2004, duas mantém a mesma tese: a de 22 de janeiro e a de 17 de junho. Cf: ENTERRÍA, Eduardo García de. La responsabilidad patrimonial del Estado Legislador en el Derecho español. 2. ed. Navarra: Civitas, 2007, p. 221.

${ }^{295}$ Espanha. Tribunal Supremo. "En nuestro sistema legal, quienes han tenido que satisfacer el gravamen complementario , impuesto por el precepto declarado inconstitucional, después de haber impugnado en via administrativa y sede jurisdiccional dicho gravamen obteniendo sentencia firme que lo declara conforme a derecho, no tienen otra alternativa, en virtud de lo dispuesto por el artículo 40.1 de la Ley Orgánica 2/1979, del Tribunal Constitucional, que ejercitar, como en este caso ha procedido la entidad demandante, una acción por responsabilidad patrimonial, derivada del acto del legislador, dentro del plazo fijado por la ley". $\mathrm{N}^{\circ}$ de Recurso: 562/1998. Relator: Jesus Ernesto Peces Morate. Disponível em: http://www.poderjudicial.es/jurisprudencia/pdf/28079130062001100776.pdf?formato=pdf\&K2DocKey=E: IS ENTENCIAS 20031030\28079130062001100776.xml@sent_TS\&query=\%28gravamen+\%3CAND\%3E+co 
Esta Sala considera, no entanto, que a ação de responsabilidade exercida é alheia ao âmbito da coisa julgada. O ressarcimento do dano causado pelo Poder Legislativo não implica deixar sem efeito a confirmação de quitação praticada, que segue mantendo todos os seus efeitos, exceto quanto ao reconhecimento de que existiu um prejuízo individualizado, concreto e claramente identificado pelo pagamento parcial de umas quantidades que resultaram serem indevidas por estarem fundadas na aplicação direta de uma disposição de caráter inconstitucional, não consentida pela interessada. ${ }^{296}$ (tradução livre)

Na sentença de 8 de março de 2001, o referido Tribunal Supremo destacou a seguinte justificativa para permitir a responsabilização estatal:

Esta Sala julga, sem embargo, nas sentenças que servem de precedente a esta, que a ação de responsabilidade exercida é alheia ao âmbito da coisa julgada derivada da sentença, pois a sentença firmemente ditada, ao não corrigir o prejuízo causado pelo preceito inconstitucional mediante a abordagem da questão da inconstitucionalidade da Lei a que acudiram outros tribunais, consolidou a atuação administrativa impugnada. ${ }^{297}$ (tradução livre)

O Tribunal Supremo justifica, explicitamente, que razões de segurança jurídica não exoneram o Estado da responsabilidade civil, como pronuncia a sentença de 16 de janeiro de 2001:

Esse princípio (da segurança jurídica), com efeito, tal como se infere da doutrina do Tribunal Constitucional em relação à declaração para a devolução dos tributos dessa natureza, realizado ao amparo de uma Lei declarada inconstitucional (p. ex., STC 45/1989), afeta ao ingresso tributário em si mesmo, ao ato administrativo em cuja força tem tomado

mplementario+\%3CAND\%3E+responsabilidad+\%3CAND\%3E+patrimonial+\%3CAND\%3E+legislador\%29 $\% 3 \mathrm{CAND} \% 3 \mathrm{E} \% 28 \% 3 \mathrm{CYESNO} \% 3 \mathrm{E} \% 28 \mathrm{fech}$ _resolucion+\%3E\%3D+20010120\%29\%29. Acesso em 26.06 .09 , p. 5.

296 Espanha. Tribunal Supremo. "Esta Sala considera, sin embargo, que la acción de responsabilidad ejercitada es ajena al ámbito de la cosa juzgada derivada de la sentencia. El resarcimiento del perjuicio causado por el poder legislativo no implica dejar sin efecto la confirmación de la autoliquidación practicada, que sigue manteniendo todos sus efectos, sino el reconocimiento de que ha existido un perjuicio individualizado, concreto y claramente identificable, producido por el abono de unas cantidades que resultaron ser indebidas por estar fundado aquél en la directa aplicación por los órganos administrativos encargados de la gestión tributaria de una disposición legal de carácter inconstitucional no consentida por la interesada." $\mathrm{N}^{\mathrm{o}}$ de Recurso: 49/1998. Relator: Juan Antonio Xiol Rios. Disponível em: http://www.poderjudicial.es/jurisprudencia/pdf/28079130062000100510.pdf?formato=pdf\&K2DocKey=E: IS ENTENCIAS $20031030 \backslash 28079130062000100510 . x m l @$ sent_TS\&query=\%28responsabilidad+\%3CAND\%3 E+estado+\%3CAND\%3E+ley+\%3CAND\%3E+inconstitucional\%29\%3CAND\%3E\%28\%3CYESNO\%3E\% 28fecha resolucion+\%3E\%3D+20000229\%29\%29. Acesso em 26.06.09., pp.9-10.

${ }^{297}$ Espanha. Tribunal Supremo. "Esta Sala estima, sin embargo, en las sentencias que sirven de precedente a ésta, que la acción de responsabilidad ejercitada es ajena al ámbito de la cosa juzgada derivada de la sentencia, pues la sentencia firme dictada, al no corregir el perjuicio causado por el precepto inconstitucional mediante el planteamiento de la cuestión de inconstitucionalidad a la que acudieron otros tribunales, consolidó la actuación administrativa impugnada". $N^{\circ}$ de Recurso: 532/1998. Relator: Jose Manuel Sieira Miguez. Disponível em: http://www.poderjudicial.es/jurisprudencia/pdf/28079130062001100383.pdf?formato=pdf\&K2DocKey=E: IS ENTENCIAS 20031018\28079130062001100383.xml@sent_TS\&query=\%28responsabilidad+\%3CAND\%3 E+estado+\%3CAND\%3E+ley+\%3CAND\%3E+inconstitucional\%29\%3CAND\%3E\%28\%3CYESNO\%3E\% 28fecha resolucion+\%3E\%3D+20000229\%29\%29. Acesso em 26.06.09, p. 4. 
lugar e a Administração que o tem percebido dentro de um sistema tributário que se rege por um princípio de equilíbrio entre ingressos e gastos. Sem embargo, dito princípio não pode ser extraído desse contexto para justificar uma exoneração do Estado pelos danos e prejuízos originados por sua atuação legislativa. Com efeito, dita atuação é alheia e de natureza distinta da atividade administrativa tributária sobre a qual aquele princípio se projeta em sua formulação pelo Tribunal Constitucional. O ressarcimento dos danos causados pela aplicação de uma Lei inconstitucional não equivale à devolução das receitas realizadas, a qual pode corresponder a um ente diferente. $O$ Estado, em sua vertente de Legislador responsável pelos prejuízos causados é alheio à Administração concreta a quem corresponde a gestão tributária amparada em uma Lei declarada inconstitucional (...), como no caso examinado. ${ }^{298}$ (tradução livre) (grifos nossos)

Logo se percebe que o referido Tribunal considera que, ainda que tenha existido uma decisão transitada em julgado aplicando uma determinada lei como constitucional, esta não elimina a possibilidade de responsabilização estatal em decorrência do ato legislativo inconstitucional, posto que tais situações são autônomas. Se a lei que criou o tributo é inconstitucional, aquele que o pagou não teria o dever de suportá-lo, de modo que houve a produção de um dano essencialmente antijurídico no entender do referido tribunal e que, portanto, geraria o direito a obter uma indenização estatal. $O$ fato de haver uma decisão judicial que houvesse declarado a constitucionalidade de tal pagamento não seria um fator impeditivo dessa ação.

Eduardo García de Enterría, contudo, critica firmemente tal posicionamento que partiria da premissa, segundo o autor, de que todos os atos administrativos liquidatários do encargo, cuja lei de criação foi declarada inconstitucional, são atos nulos de pleno

\footnotetext{
${ }^{298}$ Espanha. Tribunal Supremo. N ${ }^{\circ}$ de Recurso: 548/1998. Relator: Juan Antonio Xiol Rios. "Este principio, en efecto, tal como se infiere de la doctrina del Tribunal Constitucional, que lo aplica al ámbito tributario en relación con la devolución de los ingresos de esta naturaleza realizados al amparo de una ley declarada inconstitucional (v. gr., sentencia 45/1989) afecta al ingreso tributario en sí mismo, al acto administrativo en cuya virtud éste ha tenido lugar y a la Administración que lo ha percibido dentro de un sistema tributario que se rige por un principio de equilibrio entre ingresos y gastos. Sin embargo, dicho principio no puede extraerse de este contexto, para acudir a exonerar al Estado por los daños y perjuicios originados por su actuación legislativa. En efecto, dicha actuación es ajena y de naturaleza distinta a la actividad administrativa tributaria sobre la que aquel principio se proyecta en su formulación por el Tribunal Constitucional. El resarcimiento de los daños causados por la aplicación de la ley inconstitucional no equivale a la devolución de los ingresos realizados, la cual puede corresponder a un ente diferente. El Estado, en su vertiente de legislador responsable de los perjuicios causados a los particulares, es un ente ajeno a la Administración concreta a quien corresponde la gestión tributaria amparada en la ley declarada inconstitucional (...) como en el caso examinado (...)". Disponível em: http://www.poderjudicial.es/jurisprudencia/pdf/28079130062001100774.pdf?formato=pdf\&K2DocKey=E:IS ENTENCIAS 20031030128079130062001100774.xml@sent_TS\&query=\%28resarcimiento+\%3CAND\%3E + danos $\% 29 \% 3 \mathrm{CAND} \% 3 \mathrm{E} \% 28 \% 3 \mathrm{CYESNO} \% 3 \mathrm{E} \% 28 \mathrm{fech}$ resolucion+\%3E\%3D+20001228\%29\%29.

Acesso em 30.06.09. p. 11.
} 
direito $^{299}$. De tal posição se inferiria que, com a declaração de inconstitucionalidade da lei, haveria uma super nulidade capaz de afetar todos os atos constituídos sob a égide do referido diploma legal, de modo que todos os efeitos produzidos pela lei deveriam ser desfeitos - retroatividade geral - mediante a recomposição de eventual direito ou dano sofrido pelo particular.

Para o autor, não se poderia entender que se respeita a coisa julgada de um primeiro processo cuja decisão confere à Administração direito a perceber uma determinada dívida tributária quando se dita, posteriormente, uma segunda sentença exatamente contrária: dizendo que o contribuinte tem direito à devolução do importe integralmente pago, mais atualização monetária e juros ${ }^{300}$. Na opinião do autor, se a primeira sentença declarou a obrigação de pagamento do tributo, essa decisão fica agora sem efeito algum se resulta que a quantia desse pagamento pode ser reclamada em sua integralidade da Administração arrecadadora em um novo processo: a decisão do primeiro processo fica, pois, sem execução possível.

Diante disso, critica o autor a posição do Tribunal Supremo da Espanha, afirmando que esse órgão jurisdicional não se deu conta de que a anulação de uma lei por inconstitucionalidade pode referir-se, normalmente, a leis muito antigas. Supondo que o Tribunal Constitucional houvesse declarado que todo o sistema legal da sucessão legítima fosse incompatível com a Constituição, nenhuma só das heranças produzidas, distribuídas e liquidadas nos 115 anos do Código Civil estariam vigentes (ou ao menos nos 27 anos decorridos desde que entrou em vigor a Constituição de 1978): todas e cada uma, inclusive as consentidas em acordos de repartição ou confirmadas em virtude de sentenças com força de coisa julgada, todas, absolutamente todas, em virtude da aplicação que se faz de tal entendimento, seriam revisáveis e todas essas situações tidas por consolidadas gerariam, em virtude da doutrina da singularidade da ação de responsabilidade civil contra o Estado autor da lei anulada, uma pretensão indenizatória contra os cofres públicos, pretensão que, seguramente, excederia a todos os ativos e riquezas disponíveis, levando o Estado à

\footnotetext{
${ }^{299}$ ENTERRÍA, Eduardo García de. La responsabilidad patrimonial del Estado Legislador en el Derecho español. 2. ed. Navarra: Civitas, 2007, p. 224.

${ }^{300}$ Não se adentra aqui nas questões elencadas pelo autor relativas à competência do Tribunal Constitucional e do Tribunal Supremo para efetivação dos efeitos da declaração de inconstitucionalidade de uma lei. Para aprofundamento no tema, ver ENTERRÍA, Eduardo García de. La responsabilidad patrimonial del Estado Legislador en el Derecho español. 2. ed. Navarra: Civitas, 2007, pp. 244-249.
} 
falência. Afirma o autor, diante disso, que a regra da razoabilidade é também um princípio geral do direito, e não dos menores ${ }^{301}$.

Não seria razoável, segundo o autor, a exigência, em face do Estado, de uma responsabilidade patrimonial eterna ou imprescritível pela consequência da declaração de inconstitucionalidade de uma $\mathrm{lei}^{302}$.

O doutrinador rechaça a ideia de que, em sendo nula a lei, seriam igualmente nulos todos os atos ditados na aplicação desta, impondo-se, assim, a eliminação de todos os seus efeitos. Sustenta que, no Direito, não existe tal classe de nulidades extremas, capazes de neutralizar, excluir ou purgar todas as titularidades adquiridas por prescrição ou usucapião $^{303}$.

O raciocínio do autor, entende-se, parece que também pode ser aplicado aos casos em que ocorre a modulação dos efeitos da inconstitucionalidade no Brasil.

Ora, como já pronunciado, no Brasil, a lei, ainda que inconstitucional, pode produzir efeitos, desde que assim expressamente declarado pelo Supremo Tribunal Federal, conforme se apure razões de segurança jurídica e relevante interesse coletivo. Ocorre, portanto, uma situação em que a anulabilidade da lei desvincula-se da noção de ineficácia. As situações passadas, tanto as que se encontram sob a rubrica de coisa julgada, quanto as que se constituem sob a égide de um ato administrativo, ou firmadas entre particulares, ainda que baseadas em uma lei inconstitucional, são válidas e eficazes, pois, conforme ponderou o Supremo Tribunal Federal, guardião da Constituição, razões de segurança jurídica, que também encontram acolhida na Constituição, impõem a manutenção dessas situações.

Como pondera Ana Paula Oliveira Ávila, cujo entendimento se acolhe, só é cabível a modulação dos efeitos da inconstitucionalidade, ou seja, somente se aplica o artigo 27 da Lei 9.868/99, quando deste resultar a sobrevalência de uma norma também constitucional somente pode-se admitir a flexibilização dos efeitos da inconstitucionalidade quando essa tem em vista a proteção de bens jurídicos ou de interesses de hierarquia também

\footnotetext{
${ }^{301}$ ENTERRÍA, Eduardo García de. La responsabilidad patrimonial del Estado Legislador en el Derecho español. 2. ed. Navarra: Civitas, 2007, p. 259.

${ }^{302}$ Ibidem, p. 260.

303 Ibidem, p. 258.
} 
constitucional $^{304}$. A preservação das situações dos efeitos da norma inconstitucional deve ser também, por isso, um meio de preservação da Constituição.

Logo, admitir uma ação de responsabilidade em face do Estado em razão de uma lei declarada posteriormente inconstitucional, mas cujos efeitos foram modulados para que fossem mantidas as situações jurídicas constituídas sob sua vigência, seria o mesmo que propor uma ação visando à desconstituição dessas situações.

Como já afirmado por diversas vezes no decorrer deste trabalho, a ação de responsabilidade visa reconstituir o status quo anterior, tornar indene a vítima, minorar o seu sofrimento ou compensar a perda sofrida (como nos casos de pagamento de indenização pela ocorrência de um dano exclusivamente moral).

Já a manutenção das situações jurídicas, buscada através da modulação, deve se apresentar como a medida proporcional, ou seja, constituir-se como meio adequado e necessário para atingir a promoção da supremacia da Constituição. É, fundamentalmente, a necessidade de segurança jurídica, conjugada com a realização de direitos fundamentais, que deve servir como baliza para a flexibilização dos efeitos da inconstitucionalidade.

Assim, dado que a manutenção de determinadas situações, ainda que amparadas por meio de uma lei inconstitucional, é a opção escolhida pelo intérprete final da Constituição - Supremo Tribunal Federal -, admitir a responsabilização estatal em razão de uma lei reconhecida como inconstitucional, mas cujos efeitos foram modulados, constituiria uma forma oblíqua de desmantelá-las, o que, por certo, afrontaria não apenas a decisão da Corte que restringiu os referidos efeitos, mas todos os fundamentos que a suportam, os quais, enfim, baseados na própria Constituição, implicariam o seu próprio desrespeito.

Desse modo, pode-se concluir que a modulação dos efeitos da inconstitucionalidade, cujas justificativas para tanto se encontram em consonância com a ordem jurídica, não permitem a caracterização de um prejuízo que afronta o ordenamento, razão pela qual, uma vez ausente a antijuridicidade do prejuízo, não se tem por caracterizado um dos pressupostos aptos à responsabilização civil do Estado.

304 Cf. ÁVILA, Ana Paula Oliveira. A modulação de efeitos temporais pelo STF no controle de constitucionalidade. Porto Alegre: Livraria do Advogado, 2009, p. 67. 


\subsubsection{Responsabilidade civil do Estado por lei constitucional}

Uma lei que está em perfeita consonância com a Constituição, tanto sob o aspecto formal quanto material, não pode trazer prejuízos aos particulares. Eis o senso comum, a ideia geral que dominou durante longo período a seara jurídica administrativa.

Entretanto, o desenvolvimento de um regime da responsabilidade estatal em termos de Direito Público, que erigiu seus próprios princípios e desenvolveu uma sistemática peculiar, acolhendo a possibilidade de responsabilização do Estado inclusive pela prática de atos administrativos lícitos, remete ao questionamento desse dogma, ainda que, na hipótese, o ato que ocasione o direito à reparação seja uma lei, cuja característica de inovação e definição dos direitos torne a questão ainda mais complexa.

Yussef Said Cahali chega ao extremo de admitir que o problema da responsabilidade civil do Estado por ato legislativo estaria, na verdade, efetivamente ligado à possibilidade de indenização do dano causado pelo ato normativo conforme as regras constitucionais, e não circunscrito às hipóteses de lei inconstitucional e abuso do poder regulamentar, que constituiriam um falso problema, embora essas sejam as hipóteses normalmente ventiladas pelos autores. No seu entendimento, o princípio da irresponsabilidade do Estado por ato legislativo é colocado em crise quando a lei é promulgada com objetivo específico de sacrifício de direitos subjetivos legítimos, danoso para seus destinatários, mas em nome de um interesse político maior ${ }^{305}$.

Não é, por certo, o entendimento perfilhado neste estudo, na medida em que, por já ter-se dedicado parte deste trabalho à problemática relativa à responsabilidade civil do Estado por ato legislativo inconstitucional, considera-se a relevância e a dificuldade que a questão avulta, estando ainda a exigir estudos para propiciar um equacionamento consistente do tema, especialmente no direito brasileiro.

De modo geral, ventila-se a possibilidade de responsabilização do Estado por lei considerada constitucional de acordo com o regime aplicado aos atos administrativos lícitos e, por isso, em certas ocasiões do presente capítulo será feita remissão ao desenvolvido já anteriormente quanto à responsabilidade civil do Estado por ato lícito.

${ }^{305}$ Cf. CAHALI, Yussef Said. Responsabilidade civil do Estado. 3. ed. São Paulo: RT, 2007, p. 527. 


\subsubsection{Colocação do problema}

A lei constitucional é aquela que está em perfeita consonância com a Constituição, tanto nos aspectos materiais quanto formais. Mais do que a observância do iter formal do exercício do poder, o conteúdo da lei atende de forma adequada à valoração constitucional, estando em plena compatibilidade vertical com a norma superior. A inovação produzida na ordem jurídica através desse ato é pautada por todas as limitações e vinculações anteriores (diga-se, constitucionais), de modo que possui um traço que vai além de uma simples observância das cláusulas de repartição de competências, assumindo mesmo um conteúdo axiológico voltado a concretizar a preeminência do interesse público.

A lei constitucional que enseja a responsabilidade civil do Estado é aquela que, embora obedeça a todos os requisitos acima expostos, causa um dano diga-se antijurídico, ou seja, produz um resultado que atinge um direito ou uma situação jurídica legítima de um particular ou de um grupo deles, de forma certa e, ainda, de modo anormal e especial. Esse dano antijurídico é causado de forma indireta pelo ato, uma vez que este não tem em vista aniquilar o direito alheio - posto que nesse caso se trataria de hipótese de sacrifício de direito e deveria ser prevista a prévia indenização, como já se afirmou em capítulo anterior - mas objetiva atingir um outro interesse público que, não obstante, implica na produção de um prejuízo para o direito de um particular.

Dentre as situações ventiladas pela doutrina como suscetíveis de gerar a responsabilidade estatal em decorrência de atos legislativos constitucionais, encontram-se as hipóteses em que o Estado estabelece a seu benefício um monopólio industrial ou comercial de certa atividade, que, assim, fica interdita aos particulares, sofrendo aqueles que a exerciam a sua privação; bem como a situação em que o particular desfruta de certas vantagens econômicas asseguradas por um ato legislativo e, sendo este modificado ou revogado, resulta-lhe a supressão ou diminuição daquelas vantagens - é o caso do proprietário que, em virtude de lei, vê o seu direito de uso, gozo e disposição do imóvel exposto a restrições administrativas quanto à forma de utilização ${ }^{306}$.

Debate-se nessas situações acerca da possibilidade do Estado, no exercício de sua função legislativa, cuja característica é inovar na ordem jurídica, simplesmente modificar uma determinada orientação que resultou na criação de expectativas e/ou direitos para os

${ }^{306}$ CAHALI, Yussef Said. Responsabilidade civil do Estado. 3. ed. São Paulo: Revista dos Tribunais, 2007, p. 539. 
particulares. É possível a aplicação do princípio da segurança jurídica, em seu aspecto relativo à confiança legítima que as pessoas depositam na atividade estatal, como argumento suficiente para fazer atuar a responsabilidade civil? Pode-se concluir que, em sendo positiva a resposta anterior, não apenas a violação ao princípio da igualdade - dada a ocorrência de um prejuízo especial e anormal - mas também a violação dos princípios da segurança jurídica e da boa-fé dos particulares, em virtude da modificação abrupta de uma expectativa que o Estado gerou, constituiria um fundamento da responsabilidade civil do Estado Legislador? Na verdade, questionam-se quais os limites e que critérios resultam na vinculação do legislador que, acaso descumpridos, propiciam o nascimento de um dano antijurídico. Mas será que ao se encontrar esses limites não se estaria caracterizando a hipótese de uma lei inconstitucional, retirando a especulação do campo da responsabilidade do Estado por ato legislativo lícito?

Adianta-se que não, embora reflexões mais cuidadosas serão feitas adiante neste trabalho. Haveria situações em que a ultrapassagem desses limites não consagraria uma afronta à ordem constitucional, mas seria por ela mesma autorizada. Seriam circunstâncias, como pondera Júlio César dos Santos Esteves, em que as restrições poderiam ser consideradas necessárias, ainda que atingindo determinada parcela da coletividade, a fim de evitar risco ou prejuízo para toda essa comunidade. Não se trataria, assim, de um discrímen ou de uma diferenciação que malferiria valores constitucionais, mas que harmonizaria interesses coletivos e individuais ${ }^{307}$

Mas em que situações e quais os requisitos teriam de ser obedecidos pelo ato legislativo a fim de não caracterizar essa afronta? Por certo que tal implicaria analisar cada uma das situações jurídicas criadas pelas normas para os indivíduos, bem como avaliar se a finalidade do ato legislativo destina-se a um sacrifício de direito ou se causa indiretamente um dano, o que só poderia ser devidamente aquilatado perante o caso concreto, dada a infinidade de situações que podem ser aí albergadas. No entanto, pode-se, sem a pretensão de esgotar o assunto, estabelecer alguns parâmetros e critérios, um delineamento esquemático que pode auxiliar o intérprete nessa missão, tendo em vista já algumas questões levantadas em relação à atuação legislativa e os direitos e as situações jurídicas dos particulares.

${ }^{307}$ Cf. ESTEVES, Júlio César dos Santos. Responsabilidade civil do Estado por ato legislativo. Belo Horizonte: Del Rey, 2003, pp. 236-237. 
Começa-se, assim, por retomar os pressupostos da responsabilidade expostos anteriormente. A responsabilidade civil do Estado pela atividade (comissiva) lícita pressupõe a ocorrência de um dano antijurídico, de um nexo causal e de uma conduta estatal.

O dano antijurídico, tratando-se de atos administrativos lícitos, caracteriza-se: a) pelo atingimento de uma situação jurídica legítima, capaz, ao menos, de configurar um direito ou um interesse legítimo; b) pela sua certeza e não eventualidade; c) pela anormalidade; d) pela especialidade.

Ressalte-se considerar necessária a presença da especialidade do dano, a despeito de honrosas vozes que defendem a sua desnecessidade ${ }^{308}$, uma vez compreender-se que se tratando de dano geral e não especial o problema se deslocaria para uma hipótese de inconstitucionalidade, posto que a lei atenta, nesses casos, contra direitos assegurados pela Constituição, modificando o seu conteúdo.

Mas serão esses os mesmos pressupostos para atuação da responsabilidade por ato legislativo constitucional? Ou melhor, como se configuram esses requisitos quando deslocada a análise para o âmbito legislativo? É certo que o parâmetro da antijuridicidade do dano, no caso de atos legislativos é extraído da Constituição, e não da própria lei, como se faz em relação aos atos administrativos. A força normativa que possui a lei pode constituir uma causa de exoneração de responsabilidade para a Administração que a tenha aplicado $^{309}$, mas não proporciona nenhuma impunidade pelos danos que possa produzir, já que isso atentaria contra a garantia da responsabilidade do Poder Público ${ }^{310}$.

Subsiste o problema prático de saber, então, quais, dentre as várias posições jurídicas do particular, têm consistência jurídica suficiente para merecerem tutela reparatória no caso de ingerência estatal legislativa daquelas outras em relação às quais as incidências estatais lícitas só podem produzir desvantagens juridicamente relevantes ${ }^{311}$.

\footnotetext{
${ }^{308}$ MARIENHOFF, Miguel S. Responsabilidad del Estado por su actividad legislativa. Revista de Direito Público, São Paulo, n. 68. pp. 5-18, out./dez. 1983, p. 12 et seq.

309 Embora, cabe reforçar, compreenda-se que a responsabilidade civil do Estado é unitária, a ela se submetendo todos os atos estatais, de índole administrativa, judiciária ou legislativa.

${ }^{310}$ Cf. VIOQUE, Roberto Galán. De la teoría a la realidad de la responsabilidad del Estado legislador, p. 313. Disponível em: <http://www.cepc.es/rap/Publicaciones/Revistas/1/2001_155_285.PDF>. Acesso em 21.11.2009.

${ }^{311}$ Eis um problema já levantado por Canotilho. CANOTILHO, José Joaquim Gomes. O problema da responsabilidade do Estado por actos lícitos. Coimbra: Almedina, 1974, p. 285.
} 
Diante dessa perspectiva é que se procede à análise das questões acima levantadas, iniciando-se por um estudo do princípio da segurança jurídica, uma vez que dele se extraem, geralmente, dois aspectos: um de natureza objetiva, que envolve o limite à retroatividade dos atos do Estado, incluindo a proteção ao direito adquirido, ao ato jurídico perfeito e à coisa julgada; e outro de natureza subjetiva, no qual se compreende o princípio da proteção à confiança. $\mathrm{O}$ estudo desses dois aspectos faz-se indispensável na medida em que a quebra da norma anterior, produzida em razão da modificação legislativa, pode ensejar prejuízos, havendo que se considerar quando esses prejuízos traduzem-se em um dano apto a ensejar a responsabilização.

Não se entrará na discussão a respeito do descumprimento da lei por parte da Administração, por não ser objeto deste trabalho, mas interessa espargir luzes sobre a modificação legislativa em face dos direitos fundamentais, já que a atividade é, enfim, indispensável para guardar fidelidade aos variáveis e superiores anseios sociais.

De início, analisa-se mais cuidadosamente algumas características da atividade legislativa e, após, essas características serão confrontadas com os direitos e garantias presentes na Carta Constitucional, bem como com os interesses juridicamente protegidos dos cidadãos pela ordem jurídica brasileira.

2.2.2.2. A necessidade de liberdade para o legislador acomodar o Direito às circunstâncias cambiantes

O costume, primeira fonte do Direito, existiu antes do direito legislado, jurisprudencial ou doutrinário. Caracterizava-se pelo uso constante e uniforme, decorrente da consciência coletiva, do espírito de um povo, sob a convicção de corresponder a uma necessidade jurídica ${ }^{312}$.

Fritz Kern, citado por Eduardo García de Enterría, explica que na Idade Média o costume constituía-se em fonte primária do Direito e que sua principal característica era exatamente o de ser velho, de estar arraigado nas antigas práticas. Vigorava nessa época a ideia essencial do alte, gute Recht (em inglês good, old Law), que prescrevia ser o primeiro atentado contra a comunidade a tentativa de alterar os seus velhos costumes, nos quais o povo havia encontrado sua identidade e que se concebiam como fruto de uma revelação

\footnotetext{
${ }^{312}$ PINTO, Fernando. A presença do costume e sua força normativa. Rio de Janeiro: Líber Júris, 1982, p. 61.
} 
divina ou como decorrente da iluminação de um padre ou de um heroi histórico que haviam fundado e estabelecido para sempre a estrutura e uma ordem de funcionamento, em meio a um caos ou no entorno de inimigos existenciais ${ }^{313}$.

A nota característica do Direito Antigo, existente até o século XVIII quando se instaura na Inglaterra o princípio da supremacia parlamentar, é a de que Deus era a origem de todo o Direito, sendo que Deus se expressava pelo costume, acaso revelado por ele mesmo na origem da comunidade. Vigia, assim, um princípio contrário ao existente atualmente, qual seja, a ideia de que o Direito velho rompe ou invalida o Direito novo (legislado) $)^{314}$.

A ideia de imutabilidade do Direito predomina nos pensadores medievais, posto conceberem que a criação do direito não era nada mais do que a descoberta do direito. Percebia-se, assim, hostilidade contra qualquer mudança daquilo que por muito tempo vinha sendo praticado pelos povos.

Manoel Gonçalves Ferreira Filho resume a situação existente na época:

$\mathrm{Na}$ verdade, se se examinar o processo de estabelecimento de leis, tanto em Portugal como no restante da Europa medieval, em linhas gerais se encontra o mesmo. Em primeiro lugar, não se conhece propriamente a iniciativa legislativa, uma vez que não se considerava possível, ou admissível, criar novas regras. Admite-se, tão-somente, que, para maior clareza, sejam consolidadas, ou escritas, as regras já vigentes na comunidade. Essa função pertence ao monarca, que, todavia, não pode levá-la a cabo sem o acordo do povo, representado pela sua valentior pars. Por outro lado, essa declaração do direito existente, que é a lei medieval, em muitos países, como a França, por exemplo, não bastava por si só para estabelecer o direito que os magistrados deviam aplicar. Dependia ainda de registro pelo Parlamento, o supremo órgão judiciário, a que era facultado recusá-lo, embora essa rejeição pudesse ser superada por nova intervenção do monarca ${ }^{315}$

No entanto, as grandes revoluções modernas, propiciadas pelo clima racional que pugnava pela compreensão do Direito como expressão da razão humana, aliadas às modificações que se operavam na sociedade no âmbito industrial, técnico e comercial, acabam por atestar a insuficiência e a incompatibilidade dos costumes então vigentes para

\footnotetext{
${ }^{313}$ KERN, Fritz. Recht und Verfassung im Mittelalter. Basel, s.d., en Bruno Scwabe \& Co. Verlag. Apud ENTERRÍA, Eduardo García de. La responsabilidad patrimonial del Estado Legislador en el Derecho español. 2. ed. Navarra: Civitas, 2007, p. 52.

${ }^{314}$ Ibidem, p. 53.

${ }^{315}$ FERREIRA FILHO, Manoel Gonçalves. Do processo legislativo. 6. ed. São Paulo: Saraiva, 2007, p. 35.
} 
reger as relações sociais que ora se formavam, o que acarreta uma mudança das fontes jurídicas e, principalmente, das concepções políticas então existentes.

Os movimentos revolucionários trouxeram uma determinada ideia de representação que, por sua vez, encontrava-se intimamente ligada à separação de poderes ${ }^{316}$. O povo estaria representado no Parlamento, órgão responsável pela elaboração das leis, a qual seria, enfim, a expressão da vontade geral, o resultado da razão humana. Nenhum costume poderia prevalecer contra a lei ou a despeito dela, porque só ela encarna os imperativos da razão. A ela nada poderia ser oposto: nenhum direito subjetivo ou título anterior, os quais se encontrariam derrogados e substituídos.

Afirma-se, assim, o primado da lei, que pode inovar completamente na ordem jurídica.

Essas características levam Eduardo García de Enterría a afirmar que a imutabilidade das situações jurídicas face à lei revela-se como uma característica de um ordenamento jurídico antigo ou pré-moderno, nota que as revoluções democráticas rechaçaram completamente. Para o autor, é uma faculdade necessária do legislador, uma faculdade essencial do sistema, que ele possa modificar as leis. Ao órgão legislativo cabe, justamente, inovar o Direito, já que, por um princípio democrático, não se pode sujeitar uma geração futura, de modo algum, às leis ditadas por outras gerações, ou, ainda, pelo mesmo Parlamento, supondo que este é o único intérprete capaz de expressar juridicamente as necessidades ou políticas novas, as aspirações cambiantes do povo que, somente assim, com essa liberdade plena, pode navegar pela História.

Diante da democracia, o jurista estrangeiro não tolera a invocação de nenhuma confiança, ou comodidade, ou o interesse de alguém em manter a situação existente e que possa justificar a impossibilidade do legislador modificar a lei conforme seu arbítrio. Somente os direitos fundamentais do homem, único espaço descrito de acordo com as particularidades de cada Constituição, são irredutíveis a tal arbítrio. Qualquer intento de

\footnotetext{
316 Como destaca Manoel Gonçalves Ferreira Filho, a representação na era medieval significava a pressuposição de que os representados têm no representante um mero instrumento de expressão de sua vontade. A representação é, nesse período, a transposição do mandato civil para o plano político, o plano do Direito Público. Já na era moderna, esta traduz a noção de que o representante não representa os seus eleitores, mas a nação inteira, inclusive os que não participaram de sua eleição ou que se opuseram a ela. Trata-se de uma representação geral, mas também livre, no sentido de que o representante não está adstrito às recomendações por parte de seus eleitores e deve apreciar cada questão de acordo com a sua consciência. Cf. FERREIRA FILHO, Manoel Gonçalves. Do processo legislativo. 6. ed. São Paulo: Saraiva, 2007, pp. 65-68.
} 
condicionar a livre configuração do legislador, seja invocando-se a confiança que poderia haver na manutenção da situação legislativa, seja gravando o exercício legislativo com cargas indenizatórias em favor daqueles que invoquem um prejuízo derivado da mudança legislativa, devem resultar insustentáveis ${ }^{317}$. Destacando Jéze, dispõe o autor que pretender encerrar uma geração nas instituições políticas, administrativas e sociais então vigentes seria forçá-la à revolução e à violência ${ }^{318}$.

De fato, na Revolução Francesa e nos movimentos liberais do século XVIII, o Parlamento representava o repúdio ao absolutismo e traduzia o intento de modificação das instituições, no sentido do estabelecimento de um poder mais popular. Por isso, a ação dos parlamentos no período foi considerada como baluarte da defesa da liberdade e da democracia, identificando-se a primazia parlamentar, no que diz respeito à lei, com a democracia $^{319}$.

A lei seguia impregnada de um caráter popular e racional de acordo com a sua vinculação à origem (Parlamento), por isso fazia-se referência a ela como expressão da vontade geral.

Ocorre que hoje o Parlamento não mais se apresenta como único representante do povo, pois sofre uma deterioração crítica e funcional, uma degeneração partidarista, que torna o processo legislativo um campo de batalha onde se acotovelam os grupos de pressão. Reflete-se acerca da incapacidade da representação no modelo tradicional vinculado à atuação eleitoral, defendendo-se a existência de outros mecanismos que prevejam a participação e influência da sociedade no processo político. Fala-se mesmo numa forma de soberania complexa, que permite uma representação funcional, que se exerce através de outras estruturas institucionais consagradas no próprio texto constitucional, como o controle de constitucionalidade das leis, que nada mais seria, enfim, do que o controle do mau funcionamento da representação política ${ }^{320} 321$.

\footnotetext{
${ }^{317}$ ENTERRÍA, Eduardo García de. La responsabilidad patrimonial del Estado Legislador en el Derecho español. 2. ed. Navarra: Civitas, 2007, p. 59.

318 JÉZE, Gaston. Du retrait dês actes juridiques. Revue de Droit Public. 1913, pp. 225-229. Apud ENTERRÍA, Eduardo García de. La responsabilidad patrimonial del Estado Legislador en el Derecho español. 2. ed. Navarra: Civitas, 2007, pp. 63-64.

319 Cf. FERREIRA FILHO, Manoel Gonçalves. Do processo legislativo. 6. ed. São Paulo: Saraiva, 2007, pp. 275-276.

${ }^{320}$ Cf. VALLE, Vanice Regina Lírio do. Sindicar a omissão legislativa: real desafio à harmonia entre os poderes. Belo Horizonte: Fórum, 2007, pp. 403-405.

${ }^{321}$ V. a opinião de Manoel Gonçalves Ferreira Filho, que sugere a experimentação de novos rumos no campo da elaboração legislativa. Essas experiências, segundo o autor, ainda que amesquinhem a participação das
} 
Essa degeneração do Parlamento, o reconhecimento de sua burocracias tecnocráticas ou partidaristas ou de grupos de interesse que atuam em seu meio, levam ao reconhecimento da crise que, inevitavelmente, conduz à dessacralização $d a{ }^{2} i^{322}$, que passa a não mais ser considerada a síntese da vontade geral, mas sim o resultado da vontade de grupos que lutam pela consagração de seus próprios interesses, como já se afirmou no capítulo 1 da Segunda Parte deste trabalho.

Configura-se, assim, o desprestigio da lei, compreendida então como uma vantagem, um trunfo que se obtém pela astúcia ou pressão - ou até pela corrupção - na busca pela satisfação de interesses particulares ${ }^{323}$.

Daí que, a princípio, defender a possibilidade do legislador modificar ad nutum o Direito pode parecer mesmo que se está fazendo menoscabo dos direitos e garantias fundamentais, na medida em que resulta na falsa aparência de que se permite ao legislador simplesmente modificar um direito que já havia sido objeto de concretização por meio da lei, a qual lhe havia dado densidade normativa, restringindo-o, ou, ainda, de que é permitido ao legislador adotar providências em total contradição com as que foram por ele mesmo impostas. Essa não é, todavia, a interpretação mais apropriada da questão, nem se trata da posição que se defende neste trabalho.

Com efeito, não mais se reconhece atualmente a mesma primazia que antes envolvia o Poder Legislativo, concebido como órgão soberano, bem como o principal ato que produz: a lei. Outros parâmetros estão a pautar a ordem jurídica hodierna, destacandose os novos desenvolvimentos do Direito Internacional e do Direito Comunitário, a implantação da normatividade constitucional, decorrente da consideração da Constituição como norma jurídica, a substituição do princípio da legalidade pelo da constitucionalidade, o aumento do controle de constitucionalidade da lei, dada a própria existência de maior normatividade constitucional, circunstâncias essas que impactam sobre a sua forma de consideração e, especialmente, sobre a liberdade que se confere ao legislador para inovar na ordem jurídica.

câmaras nessa tarefa, não podem ser recusadas por serem consideradas antidemocráticas, desde que atendam aos valores fundamentais de liberdade e igualdade. Cf. FERREIRA FILHO, Manoel Gonçalves. Do processo legislativo. 6. ed. São Paulo: Saraiva, 2007, p. 278.

322 Ibidem, p. 77.

${ }^{323}$ Ibidem, p. 267. 
Qualquer lei, tanto no ordenamento pátrio quanto na maioria dos Estados modernos, deve retirar da Constituição, direta ou indiretamente, o seu fundamento de validade. Assim, tem-se que, embora o progresso social exija as constantes alterações legislativas, e é próprio que isso ocorra, como afirma Enterría - sendo oportuno até suscitar que se avulta mesmo hoje, dada a complexidade da sociedade, o reconhecimento de uma insuficiência, um retardamento legislativo face às mudanças sociais que ocorrem, o que tem levado, no Brasil especialmente, a uma ampliação da atribuição normativa ao Poder Executivo, justificada entre outros argumentos pelo seu maior conhecimento técnico e agilidade $^{324}$-, é certo também que há um núcleo intangível proposto pela Constituição que não está à livre disposição do legislador, de modo que objeta-se a modificação de direitos fundamentais nela consagrados - como o direito adquirido (artigo $5^{\circ}$, inciso XXXVI da $\mathrm{CF}$ ) - como um limite material intransponível, inclusive na hipótese em que o legislador age como Poder Constituinte Derivado, de revisão ou de emenda à Constituição, mas também impõe-se uma rigorosa observância de procedimentos para que seja possível essa alteração.

Se não se pode obstar por completo a atuação legislativa, reconhecendo-se de forma inconsequente a responsabilidade do Estado Legislador - posto observar-se necessariamente que a atribuição da responsabilidade constitui uma forma de limitação, dada a própria função preventiva que exerce -, devendo-se, por isso, admitir que seja inerente a essa atividade a possibilidade de alterações, sob pena de petrificação do Direito, por outro lado há que se considerar que resta expressamente reconhecido na Carta Maior a proteção ao direito adquirido, ao ato jurídico perfeito e à coisa julgada, razão pela qual essas situações configurariam limites incontestes à atuação legislativa, que não poderia sumariamente modificá-los, muito menos extingui-los, sem caracterizar uma hipótese de desapropriação ou de responsabilidade estatal.

Há, por certo, nos dias atuais, uma tensão já apontada por Maria Coeli Simões Pires $^{325}$ entre os postulados da estabilidade jurídica e da mutabilidade necessária da normatividade do Direito. E, como ressalta a autora, o ponto de equilíbrio entre essas duas invocações é de complexo equacionamento, não sendo nem evidente em sua expressão, nem homogêneo nos diversos ordenamentos.

\footnotetext{
${ }^{324}$ Como é o caso da atribuição de poderes quase legislativos para as agências reguladoras.

325 PIRES, Maria Coeli Simões. Direito adquirido e ordem pública: segurança jurídica e transformação democrática. Belo Horizonte: Del Rey, 2005, p. 436.
} 
Como se verá adiante, divergências ainda existem no tocante à amplitude da proteção consagrada através da norma constitucional que protege o direito adquirido face a modificação legislativa, especialmente quando se está diante de um processo de modificação da Constituição.

Maior temperamento há, ainda, no reconhecimento de situações em que não há propriamente um direito adquirido, mas uma mera expectativa, uma confiança de que o Estado continue agindo de determinada maneira como limite à atuação legislativa.

Bem por isso faz-se necessário o estudo dessas questões. Especialmente importa saber quais situações encontram-se sob a rubrica de direitos adquiridos e, ainda, a que ponto a previsão constitucional funciona como um limite ao legislador, tanto ordinário quanto constituinte. Também há que se analisar as hipóteses das expectativas dos cidadãos na continuidade do desempenho da atividade estatal. É o que se fará nos itens seguintes.

\subsubsection{A segurança jurídica}

Decorre da necessidade de estabilidade nas relações travadas entre os indivíduos a incorporação da segurança jurídica ao Direito. Por meio deste princípio pretende-se mais do que uma solução para as questões de aplicação das normas no tempo, busca-se também a previsibilidade das decisões, a submissão dos problemas aos padrões estruturados pela iteração da experiência, trazendo, com isso, uma certa coerência, indispensável à preservação do equilíbrio que permite o fluir da vida.

No aspecto jurídico, como ensina Almiro do Couto e Silva, o princípio da segurança jurídica possui dupla acepção: um de natureza objetiva, que envolve a questão dos limites à retroatividade dos atos do Estado, referindo-se à proteção ao direito adquirido, ao ato jurídico perfeito e à coisa julgada, os quais, no Brasil, encontram-se consagrados no artigo $5^{\circ}$, inciso XXXVI, da Constituição. Outro de natureza subjetiva, que diz respeito à proteção à confiança das pessoas em relação aos atos, procedimentos e condutas do Estado nos mais diferentes aspectos de sua atuação ${ }^{326}$.

\footnotetext{
${ }^{326}$ SILVA, Almiro do Couto e. O princípio da segurança jurídica (proteção à confiança) no direito público brasileiro e o direito da Administração pública anular seus próprios atos administrativos: o prazo decadencial do art. 54 da Lei do Processo Administrativo da União (Lei no 9.784/99). Revista de Direito Administrativo. Rio de Janeiro, n. 237, pp. 271-315, jul./set. 2004, p. 273-274.
} 
Analisa-se, primeiramente, o aspecto objetivo da segurança jurídica, dando especial destaque para o direito adquirido.

\subsection{Aspecto objetivo da segurança jurídica: o direito adquirido e seus correlatos (ato jurídico perfeito e coisa julgada)}

O direito adquirido, o ato jurídico perfeito e a coisa julgada constituem a dimensão objetiva do princípio da segurança jurídica, indispensável à concretização do Estado de Direito.

Reside grande dificuldade doutrinária em fixar com precisão o conceito de direito adquirido. Para Rubens Limongi França ${ }^{327}$, direito adquirido "é a conseqüência de uma lei, por via direta ou por intermédio de fato idôneo; conseqüência que, tendo passado a integrar o patrimônio material ou moral do sujeito, não se fez valer antes de lei nova sobre o mesmo objeto".

Decifrando a complexa categoria do direito adquirido, José Afonso da Silva explica que o direito adquirido é o direito subjetivo que, sendo exercitável e exigível à vontade de seu titular, tornou-se adquirido porque surgiu uma lei nova. A lei nova não pode prejudicálo, só pelo fato de o titular não o ter exercido antes. A possibilidade de exercício do direito subjetivo foi adquirida no regime da lei velha e persiste garantida em face da lei superveniente. Não se trata de uma questão de retroatividade da lei, mas tão só de limite de sua aplicação. A lei nova não se aplica à situação subjetiva constituída sob o império da lei anterior $^{328}$.

Na síntese de Maria Coeli Simões Pires ${ }^{329}$, com base nas lições de Cláudia Toledo, o direito adquirido é: "aquele apenas titularizado ou gozado antes da vigência de nova lei que disponha de modo diverso sobre os requisitos de constituição da situação jurídica, o qual atrai a aplicação da lei antiga como garantia da posição mais vantajosa para seu titular".

\footnotetext{
${ }^{327}$ FRANÇA, Rubens Limongi. A irretroatividade das leis e o direito adquirido. 3. ed. São Paulo: RT, 1982, p. 208.

${ }^{328}$ SILVA, José Afonso da. Reforma constitucional e direito adquirido. Revista de Direito Administrativo. Rio de Janeiro, n. 213, p. 121-131, jul./set. 1998, p. 123.

${ }^{329}$ PIRES, Maria Coeli Simões. Direito adquirido e ordem pública: segurança jurídica e transformação democrática. Belo Horizonte: Del Rey, 2005, p. 241.
} 
Sem adentrar, contudo, em pormenores dos aspectos que permeiam o instituto, observa-se dos conceitos expostos que a garantia do direito adquirido consagrada na Constituição visa preservar as situações jurídicas geradas através da aplicação direta da lei ou de fatos aquisitivos idôneos embasados em uma lei (norma) então vigente, da aplicação de uma lei nova, mais restritiva ou que trate de modo diverso a situação geradora do direito.

Intenta-se com isso o resguardo das situações em que, embora não tenha ocorrido o exercício de um determinado direito - e é inerente ao conceito de direito adquirido o fato de ser um direito exercitável, mas que ainda não foi exercido ${ }^{330}-$, este já foi adquirido, passou a integrar o patrimônio do seu titular, de modo que deve ficar imune à nova lei, ao que corresponde, então, o fenômeno da ultratividade da lei (projeção dos efeitos da lei para além de sua vigência, para resguardar o direito adquirido sob sua vigência). Pressuposto para a atuação da garantia é, portanto, a ocorrência de uma lei nova, que trate de modo diverso a situação geradora do direito.

Há que se ressaltar aqui a noção de que o direito adquirido, como observa Rubens Limongi França, liga-se à ideia de incorporação ao patrimônio - material ou moral - do seu titular ${ }^{331}$. Daí que o direito adquirido, associado à ideia de vantagem, exclui-se da esfera de autonomia daquele que a tenha constituído em favor do beneficiário ou da de terceiro, para integrar-se ao conteúdo da relação jurídica ou ao patrimônio de um titular. Por isso mesmo, não exercitada na vigência da lei antiga ou tendo seus efeitos diferidos no tempo, mantém-se intangível pela lei nova ${ }^{332}$.

Já o ato jurídico perfeito é, segundo o artigo $6^{\circ}, \S 1^{\circ}$, da Lei de Introdução ao Código Civil, aquele já consumado segundo a lei vigente ao tempo em que se efetuou. Trata-se, portanto, de ato que está além de um direito adquirido, sendo um direito esgotado, definitivamente exercido. Além de integrar o patrimônio do indivíduo, este já o exerceu.

\footnotetext{
330 Cf. SILVA, José Afonso da. Reforma constitucional e direito adquirido. Revista de Direito Administrativo. Rio de Janeiro, n. 213, p. 121-131, jul./set. 1998, p. 124.

${ }^{331}$ FRANÇA, Rubens Limongi. A irretroatividade das leis e o direito adquirido. 3. ed. São Paulo: RT, 1982, p. 208.

${ }^{332}$ Cf. PIRES, Maria Coeli Simões. Direito adquirido e ordem pública: segurança jurídica e transformação democrática. Belo Horizonte: Del Rey, 2005, p. 257.
} 
Situa-se também como um limite à retroatividade da lei e não poderia ser de outra forma já que, como ensina José Afonso da Silva, se o simples direito adquirido (isto é, direito que já integrou o patrimônio, mas ainda não exercido) é protegido contra interferência da lei nova, mais ainda o é o direito adquirido já consumado ${ }^{333}$.

Quanto à coisa julgada, vislumbra-se tanto do disposto no artigo $5^{\circ}, \mathrm{XXXVI}$, da $\mathrm{CF}$, quanto do artigo $6^{\circ}, \S 3^{\circ}$, da Lei de Introdução ao Código Civil que a coisa julgada apresenta-se como barreira categórica à retroatividade da lei.

Cabe assinalar que a proteção refere-se à coisa julgada material, ou seja, diz respeito à decisão definitiva, perene, imutável, que não pode mais ser discutida nem em outro processo (artigo 467 do Código de Processo Civil). A coisa julgada formal, ou seja, a decisão definitiva que não pode mais ser discutida no mesmo processo, apenas se beneficia indiretamente, na medida em que está contida na coisa julgada material.

O sentido da proteção da coisa julgada refere-se também à ideia de definitividade e segurança, pois a tutela da estabilidade dos casos julgados destina-se a fazer com que o titular do direito aí reconhecido tenha a certeza jurídica de que ele ingressou definitivamente em seu patrimônio ${ }^{334}$. Tal como o ato jurídico perfeito, a coisa julgada já estaria abrangida na proteção ao direito adquirido, sendo, na verdade, a forma de consolidação da situação mais forte que em Direito se pode imaginar.

\subsection{Aspecto subjetivo da segurança jurídica: a proteção da confiança e da boa-fé}

Os estudos sobre a manutenção ou não das situações jurídicas geradas pela confiança que os indivíduos depositam na atividade estatal ainda são recentes no direito brasileiro, como observa Maria Sylvia Zanella Di Pietro ${ }^{335}$. Aos poucos ocorre a incorporação ao ordenamento jurídico pátrio da defesa de situações decorrentes da crença dos indivíduos na continuidade de um determinado comportamento estatal, seja este decorrente da atividade administrativa, legislativa ou judiciária - cite-se como exemplo o disposto no artigo 105, III da CF/88, dispositivo esse que possibilita o manejo de recurso

\footnotetext{
${ }^{333}$ Cf. SILVA, José Afonso da. Op.cit., p. 124.

${ }^{334}$ Cf. SILVA, José Afonso da. Reforma constitucional e direito adquirido. Revista de Direito Administrativo. Rio de Janeiro, n. 213, p. 121-131, jul./set. 1998, p. 125.

${ }^{335}$ DI PIETRO, Maria Sylvia Zanella. Direito Administrativo. 22. ed. São Paulo: Atlas, 2009, p. 85.
} 
especial em virtude da existência de uma divergência jurisprudencial - bem como desponta o desenvolvimento doutrinário sobre a matéria.

Como já se assinalou, o referido princípio refere-se ao aspecto subjetivo do princípio da segurança jurídica, concernente à proteção da confiança que as pessoas têm em relação aos atos, procedimentos e condutas do Estado.

O princípio da proteção à confiança, assim denominado no direito alemão, no qual tem sua origem, é também identificado como princípio da proteção à confiança legítima, no direito comunitário europeu. Supõe um amparo que o juiz deve dar ao cidadão, frente à repentina modificação do comportamento ou forma de decidir da Administração Pública, o que faz romper a confiança do cidadão na manutenção de uma conduta que a Administração seguia em circunstâncias (políticas, sociais, econômicas) similares.

O princípio seria destinado à manutenção do status quo e a evitar que as pessoas sejam surpreendidas por modificações no direito positivo ou na conduta do Estado, mesmo quando manifestadas em atos ilegais que possam ferir os interesses dos administrados ou frustrar-lhes as expectativas ${ }^{336}$.

Segundo Judith Martins Costa, o princípio da confiança caracteriza-se, atualmente, não mais por uma lógica unicamente negativa, no sentido de se confiar numa inação estatal que tenha em vista não perturbar o espaço da livre iniciativa, dado que não se tem mais uma conjuntura econômica e filosoficamente liberal, à qual correspondia uma produção jurídica estatal eminentemente repressiva, mas possui também uma faceta positiva, na medida em que se confia na racionalização do poder do Estado e na sua ação, tendo em vista o interesse (que é social e coletivo, e não meramente individual) ao livre desenvolvimento da personalidade dos indivíduos ${ }^{337}$.

Segundo a autora:

A confiança do cidadão perante a Administração Pública vem aí conotada a um dever que se desdobra, que se bifurca em dois sentidos diversos a um mesmo sintagma - boa-fé: a Administração deve não apenas

\footnotetext{
${ }^{336}$ SILVA, Almiro do Couto e. O princípio da segurança jurídica (proteção à confiança) no direito público brasileiro e o direito da Administração pública anular seus próprios atos administrativos: o prazo decadencial do art. 54 da Lei do Processo Administrativo da União (Lei n ${ }^{\circ}$ 9.784/99). Revista de Direito Administrativo. Rio de Janeiro, n. 237, pp. 271-315, jul./set. 2004, p. 272.

${ }^{337}$ MARTINS-COSTA, Judith. Almiro do Couto e Silva e a re-significação do princípio da segurança jurídica na relação entre o Estado e os cidadãos. In: ÁVILA, Humberto (org.). Fundamentos do Estado de Direito: estudos em homenagem ao Professor Almiro do Couto e Silva. São Paulo: Malheiros, 2005, p. 135.
} 
resguardar as situações de confiança traduzidas na boa-fé (crença) dos cidadãos na legitimidade dos atos administrativos ou na regularidade de certa conduta; deve também agir segundo impõe a boa-fé, considerada como norma de conduta produtora de comportamentos ativos e positivos de proteção. (grifos da autora) ${ }^{338}$

Desse aspecto positivo, extrai-se que a proteção da confiança e a boa-fé do cidadão na atuação estatal passam a exigir, por exemplo: a manutenção dos atos administrativos inválidos, no mundo jurídico, por serem ilegais ou inconstitucionais (da proteção a confiança decorreria um certo temperamento à afirmativa contida na Súmula 473 do STF, de que os atos nulos não geram direitos); a responsabilidade do Estado pelas promessas firmes feitas por seus agentes, notadamente em atos relacionados com o planejamento econômico; a responsabilidade pré-negocial do Estado; o dever do Estado de estabelecer regras transitórias em razão de bruscas mudanças introduzidas no regime jurídico (por exemplo, na ordem econômica, no exercício das profissões, em relação aos servidores públicos) ${ }^{339}$.

No ordenamento jurídico brasileiro, a proteção da confiança, embora não tenha amparo explícito - ao menos com essa designação -, seria uma decorrência implícita do ordenamento $^{340}$. É certo que quanto aos atos administrativos, a Lei $\mathrm{n}^{\circ} 9.784$, de 29 de janeiro de 1999, estabeleceu expressamente no parágrafo único do artigo $2^{\text {o }}$ que a Administração deverá observar, nos processos administrativos, o critério da atuação segundo padrões éticos de probidade, decoro e boa-fé.

Contudo, não há previsão expressa na Constituição quanto à proteção à confiança, de modo a possibilitar que fosse considerada como explícito limite ao legislador.

O Supremo Tribunal Federal, contudo, já reconheceu que a segurança jurídica, no seu aspecto relativo à proteção à confiança, seria um princípio constitucional, imanente do Estado de Direito, podendo ser invocado, portanto, com assento constitucional para solução das controvérsias jurídicas. As decisões proferidas na MC 2.900/RS, MS n 24.268/MG e no MS 22.357/DF corroboram a hipótese, como se demonstra a seguir.

\footnotetext{
${ }^{338}$ Ibidem, p. 136.

${ }^{339}$ SILVA, Almiro do Couto e. O princípio da segurança jurídica (proteção à confiança) no direito público brasileiro e o direito da Administração pública anular seus próprios atos administrativos: o prazo decadencial do art. 54 da Lei do Processo Administrativo da União (Lei ${ }^{\circ}{ }^{9}$.784/99). Revista de Direito Administrativo. Rio de Janeiro, n. 237, pp. 271-315, jul./set. 2004, p. 278.

${ }^{340}$ DI PIETRO, Maria Sylvia Zanella. Direito Administrativo. 22. ed. São Paulo: Atlas, 2009, p. 86.
} 
No primeiro deles (MC 2.900/RS), ainda que em caráter provisório, o Ministro Gilmar Mendes, em decisão monocrática, deferiu efeitos suspensivos contra acórdão proferido pelo Tribunal Regional Federal da $4^{\mathrm{a}}$ Região, fundamentando sua decisão no princípio da segurança jurídica e na confiança legítima. Tratava-se de situação em que uma estudante do curso de Direito da Universidade Federal de Pelotas pedira transferência para a Universidade Federal do Rio Grande do Sul. Negada administrativamente a transferência após a autora já ter estabelecido seu domicílio em Porto Alegre, impetrou mandado de segurança, deferido por sentença em dezembro de 2000. Em segundo grau, contudo, o Tribunal Regional Federal da $4^{\mathrm{a}}$ Região reformou a sentença, denegando o mandado de segurança. Ajuizou, então, a autora o recurso extraordinário (manejado em outubro de 2002) e a ação cautelar para atribuir efeito suspensivo a esse recurso, uma vez que já estava prestes a concluir o curso de Direito na UFRGS. O Ministro Gilmar Mendes, reconhecendo a permanência da situação decorrente de um provimento jurisdicional provisório, deferiu a liminar reconhecendo que o princípio da segurança jurídica possui, hodiernamente, assento constitucional (princípio do Estado de Direito) e está disciplinado, parcialmente, no plano federal, pela Lei n $9.784 / 99$, de 29 de janeiro de $1999^{341}$.

Também no MS 24.268/MG ${ }^{342}$, embora a segurança tenha sido concedida com base no desrespeito ao princípio do contraditório e da ampla defesa, houve pronunciamento doutrinário do Ministro Gilmar Mendes a respeito da possibilidade de aplicação da segurança jurídica ao caso, posto que nessa situação a impetrante do referido Mandado de Segurança, a despeito de receber uma pensão previdenciária que lhe havia sido concedida de forma ilegal, já a percebia a vinte anos, de modo que não seria razoável depois do tempo decorrido o desfazimento do ato.

\footnotetext{
${ }^{341}$ Posteriormente, a decisão da medida cautelar proferida pelo Ministro Gilmar Mendes foi referendada pela $2^{\mathrm{a}}$ Turma do Supremo Tribunal Federal, cuja ementa segue nos seguintes termos: "Ação cautelar inominada. Efeito suspensivo a Recurso Extraordinário. 2. Decisão monocrática concessiva. Referendum da Turma. 3. Existência de plausibilidade jurídica da pretensão e ocorrência do periculum in mora. 4. Cautelar, em questão de ordem, referendada". Brasil. STF, Pet 2900 Questão de Ordem. Relator: Ministro Gilmar Mendes. Segunda Turma. Julgado em 27/05/2003, DJ 01-08-2003. Disponível em: http://www.stf.jus.br/portal/inteiroTeor/obterInteiroTeor.asp?numero=2900\&classe=Pet-QO. Acesso em: 11.11.09.

${ }^{342}$ MS 24.268-MG. Relatora: Ministra Ellen Gracie. Relator para acórdão: Ministro Gilmar Mendes. Julgamento: 05.02.04. Tribunal Pleno. DJ 17.09.04. Disponível em: http://www.stf.jus.br/portal/inteiroTeor/obterInteiroTeor.asp?numero=24268\&classe=MS. Acesso em: 11.11.09.
} 
Já no acórdão proferido no julgamento do MS 22.357/DF ${ }^{343}$, a confiança legítima também foi invocada como integrante do princípio da segurança jurídica, de modo que deveriam ser mantidas as situações criadas administrativamente, a despeito da ilegalidade que as acometia. A boa-fé dos impetrantes foi reconhecida como um dos elementos aptos à defesa da manutenção da situação aludida.

Com o reconhecimento de que o referido princípio constitui-se como corolário do Estado de Direito, restaria considerar se tal princípio poderia ser oposto ao legislador, caracterizando a necessidade de atribuir consequências patrimoniais no caso de alteração dessa confiança que o particular deposita na manutenção de uma determinada conduta estatal, expressa por meio da lei.

Há que se ressaltar apenas que, quando se fala em confiança legítima, não se está incluindo os direitos que foram efetivamente adquiridos, mas sim aquelas situações em que se tem uma mera expectativa, onde o direito ainda não se incorporou ao patrimônio, posto que caso se tratasse de uma lei que ferisse os bens que foram apropriados, ocorreria uma vulneração ao direito de propriedade, ao que corresponderia exatamente a uma hipótese de desapropriação ${ }^{344}$.

\subsubsection{Dos limites ao processo legislativo}

Já se afirmou que os limites ao desempenho da função legislativa encontram-se na Constituição Federal, sendo dela que se extraem as balizas para a criação do Direito pelo Parlamento.

É certo que todos os direitos e garantias individuais, dado o disposto no artigo 60, $\S 4^{\circ}$, inciso IV, da Constituição Federal, constituem-se em limites intransponíveis ao legislador, que deve necessariamente observá-los quando realiza o processo legislativo.

Poderia-se, assim, adentrar no conteúdo de todos os direitos elencados pela Constituição e verificar em que medida eles funcionam como limites ao processo

\footnotetext{
${ }^{343}$ MS 22.357-DF. Relator: Ministro Gilmar Mendes. Tribunal Pleno. Julgado em 27.05.04. DJ 05.11.04. Disponível em: http://www.stf.jus.br/portal/inteiroTeor/obterInteiroTeor.asp?numero=22357\&classe=MS. Acesso em: 11.11.09.

${ }^{344}$ SARMIENTO-ERAZO, Juan Pablo. La vulneración a la confianza legítima. ¿Una situación jurídica generadora de responsabilidad del Estado legislador? Disponível em: http://www.javeriana.edu.co/juridicas/pub_rev/documents/4Sarmiento.pdf. Acesso em 17.10.09.
} 
legislativo. Mas esse processo seria, por certo, deveras pretensioso e não esgotaria a vastidão das peculiaridades que permeiam cada um deles.

No entanto, tem-se por evidente que a necessidade de segurança jurídica em face da modificação legislativa visa à proteção das situações jurídicas consolidadas, que se incorporaram ao patrimônio moral e material do indivíduo e que, por isso, criaram verdadeiros direitos para o seu titular, independentemente de serem direitos relacionados à vida, à liberdade, à propriedade, encontrando-se, portanto, sob a rubrica de direitos adquiridos.

Daí que, sob a fórmula dos direitos adquiridos, pode-se dizer que se encontram protegidos tanto os atributos da personalidade (o estado, a capacidade) e seus aspectos morais, como também os de caráter patrimonial, tais como o direito à propriedade intelectual, à propriedade material, etc. De modo que avulta a importância do seu estudo como limite ao processo legislativo, já que diante dele se encontra a proteção de diversos outros direitos, situações jurídicas adquiridas, independentemente de se referirem à vida ou ao patrimônio do seu titular.

Também sob a rubrica das expectativas jurídicas, pode ser incluído qualquer direito que começou a se realizar, mas que ainda falta algum requisito para se completar.

São esses dois aspectos da segurança jurídica, portanto, que se entende como principais limites no balizamento do processo de alteração legislativa, uma vez que através de tal proteção se defenderá a manutenção dos demais direitos ou interesses resultantes da lei anterior.

\subsection{O direito adquirido como limite ao processo legislativo}

Importa salientar que, no ordenamento pátrio, o direito adquirido, o ato jurídico perfeito e a coisa julgada caracterizam-se como direitos fundamentais, conforme expresso no artigo $5^{\circ}$, inciso XXXVI, da CF, dispositivo esse que proíbe expressamente a lei de prejudicá-los.

Por integrar esse conjunto de direitos e garantias fundamentais, observa-se que o dispositivo funciona também como um limite material ao poder constituinte derivado (de reforma, de revisão ou de emenda), por força do disposto no artigo $60, \S 4^{\circ}$, inciso IV do 
Texto Fundamental, que proíbe a deliberação de proposta de emenda tendente a abolir os direitos e garantias individuais, cobrindo-os, assim, com o manto de cláusulas pétreas.

Todavia, embora pareça restar escancarado que o direito adquirido, o ato jurídico perfeito e a coisa julgada, por terem sido alçados à condição de direitos e garantias fundamentais, colocam-se como limites aos processos de revisão ou reforma constitucional, ainda assim a matéria gera controvérsias tanto na doutrina nacional, quanto na jurisprudência, havendo inclusive decisões proferidas pelo Supremo Tribunal Federal que desacolhem a oponibilidade dessa barreira ao poder constituinte derivado. Confira-se, por exemplo, trecho do voto proferido pelo Ministro Moreira Alves, Relator da decisão proferida no Recurso Extraordinário n ${ }^{\circ}$ 94.414, a qual, embora anterior à vigência da atual Constituição, traz em seu bojo lições para a interpretação de norma constitucional que disponha que a lei nova não prejudicará o direito adquirido, o ato jurídico perfeito e a coisa julgada, in verbis:

As normas constitucionais se aplicam de imediato, sem que se possa invocar contra elas a figura do direito adquirido. Mesmo nas Constituições que vedam ao legislador ordinário a edição de leis retroativas, declarando que a lei nova não prejudicará o direito adquirido, o ato jurídico perfeito e a coisa julgada, esse preceito se dirige apenas ao legislador ordinário, e não, ao constituinte, seja ele originário, seja ele derivado ${ }^{345}$.

Dentre os doutrinadores, Paulo Modesto, um dos defensores dessa posição, utilizase do argumento de que há diferenças entre a garantia do direito adquirido e o direito adquirido propriamente dito. Segundo o autor, somente a garantia do direito adquirido, que consiste no bloqueio de toda e qualquer alteração do estatuto fundamental, se encontraria sob a rubrica de cláusula pétrea e não o direito adquirido propriamente dito, uma vez que este corresponderia às situações jurídicas individuais. Nas palavras do autor:

As cláusulas pétreas, também chamadas de cláusulas de imutabilidade ou garantias de eternidade, são limites materiais ao poder de reforma constitucional. Referem a conteúdos, princípios, normas constitucionais que não podem ser objeto de deliberação pelo poder de reforma constitucional. Dizem respeito a normas que constam da Constituição e não a situações jurídicas concretas titularizadas pelo Poder Público ou por particulares. Revestem-se de eficácia reforçada, na medida em que denotam normas constitucionais que somente podem ser derrogadas pelo poder constituinte originário. Constituem exceção ao poder de reforma constitucional e, como tais, reclamam interpretação estrita. Sintetizam a idéia fundamental de direito da coletividade, compondo a identidade

${ }^{345}$ BRASIL. Supremo Tribunal Federal. RE no 94.414. Julgado em 13.02.1985. DJ 19.04.1985. Disponível em: http://www.stf.jus.br/portal/inteiroTeor/obterInteiroTeor.asp?numero=94414\&classe=RE. Acesso em: 18.11.2009. 
básica da Constituição. Reformá-las é inviável para os órgãos constitucionais instituídos, pois significaria o mesmo que a retirada dos alicerces que os sustentam e a derrubada da Constituição ${ }^{346}$.

Para Paulo Modesto, o que está consagrado como cláusula pétrea na Constituição seria a garantia do direito, ou seja, restaria proibido que as emendas constitucionais suprimissem do texto fundamental a norma jurídica, ao que não corresponde, portanto, uma proteção intangível aos direitos incorporados ao patrimônio dos indivíduos.

Outro argumento de que se vale para firmar a sua tese refere-se às diferenças entre lei e emenda constitucional, as quais seriam entidades claramente distintas: a primeira constitui um veículo ordinário de expressão normativa, que irrompe com agilidade o processo legislativo, embora encontre ampla delimitação material fornecida pela Constituição, enquanto que a segunda é um veículo normativo extraordinário, episódico, de dificílima produção no plano processual, mas sujeita a menores restrições de caráter material, as cláusulas pétreas. Essas diferenças não poderiam ser desconsideradas através de uma interpretação que submetesse as emendas aos mesmos limites do legislador ordinário.

De modo que, segundo o autor, o termo lei, utilizado no referido artigo $5^{\circ}$, deveria ser interpretado de forma restrita, como referente apenas aos atos legislativos provenientes do legislador infraconstitucional, ou seja, abrangeria apenas as leis em sentido formal, razão pela qual não se poderia invocar a proteção do direito adquirido em face de normas constitucionais elaboradas por meio de emenda de revisão ou reforma.

Ousa-se aqui discordar, contudo, da interpretação proposta por Modesto. Primeiramente, porque parece que a defesa tão somente da impossibilidade de suprimir norma de garantia do texto constitucional promove, consequentemente, o esvaziamento do conteúdo jurídico da garantia, o seu efeito prático, como bem observa José Afonso da $\mathrm{Silva}^{347}$. E isso seria o mesmo que promover uma garantia que protege o nada jurídico, já que seria plenamente possível eliminar um direito que se efetiva e se concretiza num titular.

\footnotetext{
${ }^{346}$ MODESTO, Paulo. Reforma administrativa e direito adquirido. Revista de Direito Administrativo. Rio de Janeiro: Renovar, n. 211, pp. 79-94, jan./mar. 1998, p. 83.

${ }^{347}$ Reforma constitucional e direito adquirido. Revista de Direito Administrativo. Rio de Janeiro, n. 213 , p. 121-131, jul./ set. 1998, p. 131.
} 
Ademais, a prevalência de tal entendimento representaria, por certo, a submissão da vontade do poder constituinte originário à vontade do poder constituinte derivado, como aduz Maria Sylvia Zanella Di Pietro ${ }^{348}$. Se o poder constituinte derivado (de reforma, revisão ou de emenda da Constituição), como a própria designação explicita, expressa sua autoridade na delegação constitucional, não se manifestando senão com a observância das condições postas pela Constituição (condicionado), havendo, ainda, que respeitar as limitações que essa impõe (limitado), logo é fácil vislumbrar que a possibilidade de vulneração, de afetação do conteúdo de um direito adquirido, representa uma mudança contra a Constituição, uma revolução que somente o Poder originário pode efetuar ${ }^{349}$.

Logo, o poder constituinte derivado não poderia se esquivar de respeitar as situações jurídicas individuais que se tornaram direitos adquiridos, sob pena de inconstitucionalidade e, consequentemente, de vulneração da estabilidade buscada pelo ordenamento jurídico. A interpretação do termo lei previsto no citado comando normativo deveria ser realizada, portanto, de forma finalística, atrelada que está na busca pela segurança jurídica, abrangendo, assim, qualquer ato normativo, desde as emendas constitucionais até os mais particulares e limitados atos emanados do Poder Executivo.

Cabe ressaltar que a tese referente à possibilidade de existência de emendas constitucionais que atentam contra a Carta Maior já foi acolhida pelo Supremo Tribunal Federal quando do julgamento da ADIN $\mathrm{n}^{\circ}$ 939, cujo objeto era avaliar a inconstitucionalidade da Emenda à Constituição nº 03/1993, que instituiu imposto sobre a movimentação financeira (IPMF), por não respeitar os princípios da anterioridade e da imunidade tributária recíproca entre os entes estatais ${ }^{350}$. Também no acórdão proferido por ocasião do julgamento da $\mathrm{ADIN} \mathrm{n}^{\circ}$ 2.024-DF, embora o STF não tenha reconhecido a inconstitucionalidade que ora se apontava, assim restou claro no voto do Ministro Relator Sepúlveda Pertence:

A viabilidade do controle de constitucionalidade abstrato de emenda constitucional - repressiva ou preventivamente - , sob o argumento de

\footnotetext{
${ }^{348}$ DI PIETRO, Maria Sylvia Zanella. Direito Administrativo. 22. ed. São Paulo: Atlas, 2009, p. 585.

349 Cf. FERREIRA FILHO, Manoel Gonçalves. Poder Constituinte e direito adquirido. Revista de Direito Administrativo. Rio de Janeiro, n. 210, pp. 1-9, out./dez. 1997, p. 3.

${ }^{350}$ É o que se pode verificar do seguinte trecho da ementa elaborada pelo Ministro Relator Sidney Sanches: “(...) Uma Emenda Constitucional, emanada, portanto, de Constituinte derivada, incidindo em violação a Constituição originaria, pode ser declarada inconstitucional, pelo Supremo Tribunal Federal, cuja função precípua é de guarda da Constituição (art. 102, I, "a", da C.F.)". Tribunal Pleno. Julgado em 15.12.93. DJ 18.03.94. Disponível 
ofensa a princípio alçado pelo poder constituinte originário instituído à condição de intangível, já está sedimentada na jurisprudência do Tribunal, conforme demonstram os precedentes citados quando do julgamento da cautelar e outros ulteriores ${ }^{351}$.

Há que se lembrar, contudo, que essa limitação ao legislador quer significar que nem por via direta nem por via indireta, oblíqua, dissimulada poderia ser afrontado o direito adquirido, o ato jurídico perfeito e a coisa julgada. Isso significa que nenhum legislador, nem o dotado de maior discricionariedade, nem o que se submete a rígidos e estritos controles, poderá esquivar-se da limitação imposta pelo Poder Constituinte Originário.

Quanto a este último, cabe-nos salientar que é o único que não se encontra adstrito a nenhum direito adquirido vigente no momento em que elabora e edita a Lei Magna. Por ser originário, incondicionado e ilimitado, juridicamente não fica sujeito a nenhuma regra do ordenamento existente nem da Constituição que vigorava antes, podendo romper com todos os direitos adquiridos anteriores.

Vale ressaltar, contudo, que as Constituições, a despeito de não serem condicionadas nem limitadas, podem desejar manter um direito que foi adquirido sob a égide da Constituição anterior. Como ensina José Afonso da Silva ${ }^{352}$ :

\begin{abstract}
Não é que o Poder constituinte não respeita os direitos adquiridos anteriores. A tese é diferente. Ele não está jungido aos direitos anteriores, adquiridos ou não. Ele tem a faculdade de desfazê-lo explícita ou implicitamente. Pois as normas constitucionais originárias também estão submetidas ao mesmo princípio geral que regem todas as leis jurídicas, qual seja o princípio da incidência imediata e geral, passando a reger as situações e condutas presentes e futuras, desde sua entrada em vigor. A irretroatividade das normas, inclusive das normas constitucionais, é um princípio geral de direito, a diferença é que a norma constitucional originária pode colher fatos a ela anteriores, como nota Manoel Gonçalves Ferreira Filho. 'Em conseqüência (adita o ilustre mestre) pode dar-lhe caráter (lícito ou ilícito) diferente do que tinham na ordem jurídica anterior. Igualmente pode pôr termo a direitos adquiridos'.
\end{abstract}

Nesse sentido, conclui-se que um direito que passou a integrar o patrimônio de um particular tanto encontra proteção constitucional em face do que dispõe o artigo $5^{\circ}$, inciso XXXVI, da Constituição, conjugado com o disposto no artigo $60, \S 4^{\circ}$, da $\mathrm{CF}$, já que a

\footnotetext{
${ }^{351}$ ADI 2024. Relator: Ministro Sepúlveda Pertence. Tribunal Pleno. Julgado em 03/05/2007. DJ 22-06$2007 . \quad$ Disponível http://www.stf.jus.br/portal/inteiroTeor/obterInteiroTeor.asp?numero=2024\&classe=ADI. Acesso em $12 / 11 / 2009$.

${ }^{352}$ Reforma constitucional e direito adquirido. Revista de Direito Administrativo. Rio de Janeiro, n. 213 , p. 121-131, jul./ set. 1998, p. 128.
} 
proteção ali referida não se circunscreve a uma garantia de não supressão da cláusula, mas refere-se também às situações jurídicas individuais, como também encontrará proteção em outro dispositivo constitucional que corresponda ao direito fundamental caracterizado, tal como o direito de propriedade, o direito à honra, o direito à imagem, etc. Daí constituírem limites à atuação legislativa ordinária ou decorrente do poder constituinte derivado, que não poderá afastá-los diante da necessária observância da supremacia constitucional.

\subsection{A proteção à confiança como limite ao legislador}

É certo que não é qualquer ato estatal que tem o papel de incutir nos indivíduos uma confiança e, ademais, não é qualquer confiança que pode ser tutelada pelo ordenamento jurídico. Como vislumbra Odete Medauar, cada situação terá a peculiaridade para detectar, ou não, a confiança suscitada ${ }^{353}$.

Já se anunciou que a segurança jurídica possui assento constitucional, tal como reconhecido pelo STF, sendo que um dos seus aspectos refere-se à proteção à confiança.

No campo legislativo, observa-se que não há unanimidade entre os autores quanto às consequências decorrentes da aplicação do princípio da proteção à confiança, de forma que o princípio poderia concretizar-se de inúmeros modos, sendo que a proteção frente a uma modificação legislativa de uma situação jurídica que não se completou como um direito adquirido é apenas um dos aspectos que poderiam ser expressos pelo citado princípio.

Rubio Llorente ${ }^{354}$, magistrado que atuou nos primeiros doze anos de funcionamento do Tribunal Constitucional da Espanha, em trabalho no qual realizou uma recopilação em matéria de direitos fundamentais e princípios constitucionais, conforme citação de García de Enterría, declara que a confiança legítima dos cidadãos restaria prejudicada quando o legislador emanasse uma legislação confusa, obscura ou incompleta que dificultasse a sua aplicação, conduzindo assim à incerteza do Direito. O princípio seria destinado a proteger,

\footnotetext{
${ }^{353}$ MEDAUAR, Odete. Segurança jurídica e confiança legítima. In: ÁVILA, Humberto (org.). Fundamentos do Estado de Direito: estudos em homenagem ao Professor Almiro do Couto e Silva. São Paulo: Malheiros, 2005, p. 117.

${ }^{354}$ LLORENTE, F. Rubio. Derechos fundamentales y principios constitucionales (Doctrina constitucional). Barcelona: (sine nomine), 1995, p. 67 e seguintes. Apud ENTERRÍA, Eduardo García de. La responsabilidad patrimonial del Estado Legislador en el Derecho español. 2. ed. Navarra: Civitas, 2007, p. 38.
} 
dessa forma, a certeza do Direito e não estaria relacionado à preservação de interesses particulares.

Odete Medauar, por sua vez, destaca que a exigência de leis claras e precisas, bem como a necessidade de grau de concreção suficiente na disciplina de certa matéria - já que o caráter vago da norma implicaria, muitas vezes, a delegação de competência ao Executivo e ao Judiciário - seriam decorrências do princípio da segurança jurídica e não relativamente ao seu aspecto de proteção à confiança, sendo que este estaria relacionado "à continuidade das leis, à confiança dos indivíduos na subsistência das normas"355.

Entretanto, ressalva a autora que a proteção à confiança:

não protege os cidadãos genericamente de toda alteração legal, pois cada situação terá a peculiaridade para detectar, ou não, a confiança suscitada. Apresenta-se mais ampla que a preservação dos direitos adquiridos, porque abrange direitos que não são ainda adquiridos, mas se encontram em vias de constituição ou suscetíveis de se constituir; também se refere à realização de promessas ou compromissos da Administração que geraram, no cidadão, esperanças fundadas; visa, ainda, a proteger os particulares contra alterações normativas que, mesmo legais, são de tal modo abruptas ou radicais que suas conseqüências revelam-se chocantes ${ }^{356}$.

Utilizando-se da lição de Egon Bockmann Moreira ${ }^{357}$, parece acertado concluir que, a despeito da dificuldade de se definir o conteúdo de um princípio jurídico, disso não pode derivar sua inaplicabilidade, de modo que daí surge a necessidade de cercá-lo de todos os possíveis significados, de molde a ampliar a sua incidência.

Nesse sentido, poderia-se compreender que a proteção à confiança abrange tanto o dever de emanar atos legislativos claros, precisos e completos, quanto revela a necessidade de proteger os cidadãos face às alterações estatais legislativas arbitrárias e, ainda, compreende a necessidade de realização pelo Estado das promessas e compromissos que geraram fundadas esperanças nos indivíduos.

Todavia, como bem advertiu Odete Medauar, a invocação do princípio da confiança não se traduz, consequentemente, numa proteção genérica do cidadão frente a toda e qualquer alteração legislativa. É certo, como resta reconhecido pela autora, que admitir a

\footnotetext{
${ }^{355}$ MEDAUAR, Odete. Segurança jurídica e confiança legítima. In: ÁVILA, Humberto (org.). Fundamentos do Estado de Direito: estudos em homenagem ao Professor Almiro do Couto e Silva. São Paulo: Malheiros, 2005, p. 117.

${ }^{356}$ MEDAUAR, Odete. Op. cit., p.117.

${ }^{357}$ MOREIRA, Egon Bockmann. Processo administrativo: princípios constitucionais e a Lei 9.784/1999. 3 ed. São Paulo: Malheiros, 2007, p. 103.
} 
aplicação do princípio da proteção à confiança à atividade legislativa é limitar a liberdade de alterar a legislação ou a disciplina normativa existente em certa matéria, impondo ao legislador ou à autoridade administrativa a necessidade de previsão de um regime de transição, quando ocorrerem modificações de leis vigentes, sobretudo para direitos ainda não adquiridos, mas em vias de aquisição, ou suscetíveis de aquisição ${ }^{358}$.

Diante do desenvolvimento do tema na Espanha e no âmbito da Comunidade Europeia, vale a pena aqui observar como tem sido a aplicação do princípio face ao legislador em tais ordens jurídicas, especialmente porque, como destaca Judith MartinsCosta, este princípio vem assumindo um papel significativo no Direito Administrativo europeu, aplicando-se, por exemplo, ora para reforçar o dever de motivação dos atos administrativos, ora para proteger os estados de fato que não se põem, a rigor, como direitos adquiridos, mas como situações de fundada confiança ou de fundada expectativa no comportamento estatal ${ }^{359}$.

Da pesquisa empreendida, observa-se que tanto a Espanha quanto o Tribunal de Justiça da Comunidade Europeia já se depararam com pedidos indenizatórios que invocavam o princípio da confiança legítima para amparar a responsabilidade do Estado Legislador. É de se ressaltar a importância que tiveram essas decisões tanto na Espanha quanto na Comunidade Europeia, tal como destaca Juan Pablo Sarmiento-Erazo, na medida em que se busca nessa comunidade justamente promover um projeto de unificação econômica que exige a garantia de expectativas legítimas para responder a necessidade de uma integração de mercado, que permita o livre fluxo de bens e serviços, e que, ademais, deve admitir a intervenção de cada Estado em sua economia interna e a liberdade de configuração dos respectivos sistemas jurídicos ${ }^{360}$.

O primeiro caso em que se invocou o princípio da confiança legítima na Espanha ocorreu logo após o ingresso deste país na Comunidade Econômica Europeia, cuja adesão ao Tratado foi autorizada pela Lei Orgânica 10/1985, de 2 de agosto desse ano. Essa lei

\footnotetext{
${ }^{358}$ MEDAUAR, Odete. Segurança jurídica e confiança legítima. In: ÁVILA, Humberto (org.). Fundamentos do Estado de Direito: estudos em homenagem ao Professor Almiro do Couto e Silva. São Paulo: Malheiros, 2005 , p. 118.

${ }^{359}$ Cf. MARTINS-COSTA, Judith. Almiro do Couto e Silva e a re-significação do princípio da segurança jurídica na relação entre o Estado e os cidadãos. In: ÁVILA, Humberto (org.). Fundamentos do Estado de Direito. São Paulo: Malheiros, 2005, p. 139.

${ }^{360}$ SARMIENTO-ERAZO, Juan Pablo. La vulneración a la confianza legítima. ¿Una situación jurídica generadora de responsabilidad del Estado legislador? Disponível em: http://www.javeriana.edu.co/juridicas/pub_rev/documents/4Sarmiento.pdf. Acesso em 17.10.09, p. 95.
} 
modificou a regulação anterior existente, que concedia importantes benefícios físcais a várias empresas pesqueiras, as quais aproveitaram as condições favoráveis para ampliar sua atividade econômica. Contudo, após a adesão da Espanha ao Tratado, essas empresas ajuizaram demandas de reparação contra o Estado, o que culminou com as sentenças de 5 de março de $1993^{361}$, 27 de junho de 1994 e 16 de setembro de $1997^{362}$ proferidas pelo Tribunal Supremo, que reconheceu, a despeito da ampla liberdade de configuração que é conferida ao legislador para definir o ordenamento jurídico e a direção das relações internacionais, que esse deveria ser responsabilizado, pois a integração internacional havia causado aos particulares prejuízos econômicos especiais.

Essas decisões expressam que o Estado fica obrigado a responder - ainda que o princípio da boa-fé não garanta aos agentes econômicos a perpetuação da situação jurídica existente, nem se reconheça um direito adquirido à manutenção de uma vantagem - pelo marco comunitário de alteração, dada a ausência de conhecimento antecipado, de medidas transitórias suficientes para que os sujeitos pudessem acomodar sua conduta econômica ao interesse público em jogo, sem as devidas medidas compensatórias das circunstâncias econômicas habituais e estáveis que geravam esperanças fundadas na sua manutenção ${ }^{363}$.

Daí o reconhecimento no referido país de que somente são indenizáveis aquelas expectativas legitimamente fundadas em disposições que fomentem atividades econômicas e que determinem ao indivíduo o desenvolvimento de determinadas ações de investimentos.

Em outra situação em que também se invocava o princípio da confiança para amparar um pedido indenizatório em face do Estado, não se tratando, contudo, de legislação destinada ao fomento econômico, não se acolheu, de modo geral, o pedido indenizatório. Trata-se da ocasião em que os funcionários do Estado pleiteavam indenização em virtude da promulgação da Lei $n^{\circ} 30$, de 1984, que reduziu a idade de

361 Sentença de 5 de março de 1993. Relator: Pedro Antonio Mateos García. Disponível em: http://www.poderjudicial.es/search/doAction?action=contentpdf\&databasematch=TS\&reference=1095568\&l inks=empresa $\% 20 y \% 20$ pesquera\&optimize=20051201. Acesso em: 16.12.09.

${ }^{362}$ Cf. consta da própria sentença de 16 de setembro de 1993. Recurso 265/1988. Sentença de 16 de setembro de 1993. Relator: Jose Manuel Sieira Miguez. Disponível em: http://www.poderjudicial.es/search/doAction?action=contentpdf\&databasematch=TS\&reference=3155451\&l inks=responsabilidad\%20y\%20estado\&optimize=20030912. Acesso em: 13.10.09.

${ }^{363}$ Cf. ENTERRÍA, Eduardo García de. La responsabilidad patrimonial del Estado Legislador en el Derecho español. 2. ed. Navarra: Civitas, 2007, p. 32 e também SARMIENTO-ERAZO, Juan Pablo. La vulneración a la confianza legítima. ¿Una situación jurídica generadora de responsabilidad del Estado legislador? Disponível em: http://www.javeriana.edu.co/juridicas/pub_rev/documents/4Sarmiento.pdf. , Acesso em 17.10.09, p. 90. 
aposentadoria de 70 para 65 anos, ato que causou frustração nas expectativas dos servidores públicos que pretendiam obter pensões mais vantajosas. $O$ Tribunal Constitucional reconheceu a constitucionalidade da lei, mas, por sua vez, o Tribunal Supremo, na decisão de 30 de novembro de 1992, que serviu como paradigma às demais decisões que se formaram em virtude dos inúmeros questionamentos judiciais que surgiram, denegou os pedidos indenizatórios, sendo que, dentre os argumentos utilizados, defendeu que não se poderia pretender a responsabilidade estatal em face de meras expectativas de direitos, já que admitir o contrário seria conduzir a uma petrificação legislativa $^{364}$.

Tanto os doutrinadores espanhois que criticaram essa sentença e que a denominaram, inclusive, de antilafleurette espanhola ${ }^{365}$, como os que a apoiaram ${ }^{366}$ reconheceram que uma eventual decisão de concessão da indenização, diante do elevado número de pessoas afetadas, conduziria a uma enorme carga econômica para os cofres públicos, agravando ainda mais a crise econômica que ocorria no país naquele ano ${ }^{367}$.

As decisões favoráveis à concessão de indenização não foram, contudo, acatadas tranquilamente pelos doutrinadores espanhois. Eduardo García de Enterría, jurista do referido país, depois de reconhecer que tanto o princípio da segurança jurídica como o da proteção à confiança são princípios que informam a totalidade do ordenamento, aduz que tais princípios somente alcançam verdadeira força constitucional, com capacidade para

${ }^{364}$ ENTERRÍA, Eduardo García de. La responsabilidad patrimonial del Estado Legislador en el Derecho español. 2. ed. Navarra: Civitas, 2007, pp. 69-70.

${ }^{365}$ Cf. VIOQUE, Roberto Galán. De La teoria a la realidad de La responsabilidad del Estado legislador. Disponível em: <http://www.cepc.es/rap/Publicaciones/Revistas/1/2001_155_285.PDF>. Acesso em: 21.11.2009, p. 305.

${ }^{366}$ Cf. ENTERRÍA, Eduardo García de. La responsabilidad patrimonial del Estado Legislador en el Derecho español. 2. ed. Navarra: Civitas, 2007, p. 69.

367 Outra situação ocorrida deu-se com a Lei do Parlamento Autônomo no 5 de 1986, conforme indica Juan Pablo Sarmiento-Erazo, que aplicava um imposto sobre combustíveis derivados do petróleo, lei essa que conduziu os comerciantes de tais produtos a vender seus estoques a preços inferiores aos adquiridos. Por este fato, o Tribunal Supremo espanhol declarou o Estado Legislador responsável, entendendo que este não levou em consideração as situações jurídicas individualizadas, tendo o dever de dispor sobre medidas transitórias que garantissem a equidade tributária e evitassem possíveis desequilíbrios na atividade empresarial. Segundo o referido autor, nessa decisão há uma dupla justificativa para reconhecimento da reparação das expectativas legitimamente criadas. A primeira corresponderia à noção de que as modificações abruptas podem romper com o equilíbrio de situações anteriores à expedição da norma, gerando com isso uma vulneração da igualdade na medida em que as situações preexistentes mais favoráveis criam expectativas e conduzem o particular a tomar decisões econômicas baseadas em supostos normativos vigentes. A segunda justificativa consiste numa omissão legislativa geradora do dano. Essa se caracterizaria pela ausência de previsão de pagamento de indenização, o que, segundo o Supremo Tribunal espanhol deveria ocorrer quando há ausência de normas de transição e o prejuízo ao particular ocorre de modo anormal. Cf. SARMIENTO-ERAZO, Juan Pablo. La vulneración a la confianza legítima. ¿Una situación jurídica generadora de responsabilidad del Estado legislador? Disponível em: http://www.javeriana.edu.co/juridicas/pub_rev/documents/4Sarmiento.pdf. Acesso em 17.10.09., p. 92. 
impor-se às leis e de enfraquecer ou aditar o seu conteúdo (pois, segundo o autor, ligar a uma lei a necessidade de uma indenização como consequência de sua aplicação trata-se de evidente inovação ao seu conteúdo) em casos verdadeiramente extremos e singulares. Explicando a origem do princípio da confiança no direito alemão, o autor conclui que tal princípio serve como um limite ao problema da retroatividade ou irretroatividade das leis, não sendo fundamento para se reconhecer, entretanto, a responsabilidade estatal. A proteção à confiança, segundo o doutrinador, não é argumento suficiente para declarar a inconstitucionalidade de uma lei, nem o Tribunal Constitucional da Espanha assim o fez em qualquer ocasião ${ }^{368}$.

No âmbito da Comunidade Europeia, cabe considerar, inicialmente, que não há disposição comunitária expressa a respeito da responsabilidade civil do Estado, o que não impede, no entanto, que o Tribunal de Justiça da CE a compreenda como inerente ao Tratado da referida Comunidade, dada a autonomia da ordem jurídica comunitária, as exigências de uma proteção efetiva e eficaz dos direitos que esta confere aos particulares e o dever de cooperação e lealdade que resulta do Tratado da $\mathrm{CE}^{369}$. No entanto, considera que para imputar a responsabilidade a alguns dos seus Estados membros é insuficiente a simples violação do tratado, de forma que se deve ter uma ilegalidade que tangencie uma arbitrariedade e que produza um dano anormal, derivado precisamente de uma ilegalidade suficientemente caracterizada. Segundo Marta Chantal da Cunha Machado Ribeiro:

O critério decisivo para que se considere uma violação suficientemente caracterizada é o da existência de uma violação manifesta e grave, tanto por um Estado-membro, como por uma instituição comunitária, dos limites que se impõem ao seu poder de apreciação ${ }^{370}$

Outra condição invocada para permitir a responsabilização refere-se à necessidade de que a disposição comunitária violada tenha por objeto conferir direitos aos particulares, de modo que não bastará a ilegalidade, devendo a norma violada estar de acordo com o interesse subjetivo do reclamante ${ }^{371}$.

\footnotetext{
${ }^{368}$ Cf. ENTERRÍA, Eduardo García de. La responsabilidad patrimonial del Estado Legislador en el Derecho español. 2. ed. Navarra: Civitas, 2007, p. 36 passim.

${ }^{369}$ Cf. RIBEIRO, Marta Chantal da Cunha Machado. O regime de responsabilidade civil extracontratual dos Estados-membros pela violação do direito comunitário: delineamento e aperfeiçoamento progressivo. Disponível em: www.almedina.net. Acesso em: 12.11.2009, p. 12.

${ }^{370}$ Cf. RIBEIRO, Marta Chantal da Cunha Machado. O regime de responsabilidade civil extracontratual dos Estados-membros pela violação do direito comunitário: delineamento e aperfeiçoamento progressivo. Disponível em: www.almedina.net. Acesso em: 12.11.2009, p. 12.

371 Ibidem, p. 11 et. seq. E também: ENTERRÍA, Eduardo García de. La responsabilidad patrimonial del Estado Legislador en el Derecho español. 2. ed. Navarra: Civitas, 2007, p. 47.
} 
Diante de tais requisitos, da necessidade de uma violação manifesta ao tratado da comunidade e de que essa disposição tenha por objeto conferir direitos aos particulares, compreende o Tribunal que o legislador não pode ser limitado por ações indenizatórias quando, em consideração ao interesse geral, adote medidas que possam causar danos aos particulares. Haveria uma imunidade das opções de política econômica editadas pelos Estados, que seriam atos estritamente normativos, nos quais residiria uma grande margem de discricionariedade, razão pela qual deveriam ser respeitadas, por se tratarem de uma forma de exercício da soberania dos Estados. ${ }^{372}$.

A sentença paradigma é Bayerische HNL, de 25 de maio de 1978, que invoca a inexistência de uma responsabilidade por atos legislativos no Direito interno dos Estados e é categórica ao afirmar que:

O poder legislativo não pode ser obstaculizado em suas disposições cada vez que se encontra no caso de adotar, em consideração ao interesse geral, medidas normativas suscetíveis de causar prejuízos aos interesses dos particulares ${ }^{373}$ (tradução livre)

García Macho, em estudo sistemático da jurisprudência do Direito Comunitário, assinala, sobre esse ponto, que a atitude restritiva do Tribunal frente à proteção à confiança legítima provém do caráter perturbador que esse princípio causa aos objetivos dos poderes públicos e que, inclusive, pode questionar outros princípios gerais, como o princípio da legalidade. Por isso o Tribunal somente considera infringida a confiança legítima quando a norma é "a tal ponto desestabilizadora que rompe os limites razoáveis das relações entre administração e administrado",374.

Na sentença Merkur Ausenhandeln GmbH, de 15 de setembro de 1977, o Tribunal disse que o princípio da confiança legítima aplica-se, essencialmente, no caso em que um operador econômico tenha previamente fixado a soma que havia de pagar ou receber no

\footnotetext{
${ }^{372}$ Cf. SARMIENTO-ERAZO, Juan Pablo. La vulneración a la confianza legítima. ¿Una situación jurídica generadora de responsabilidad del Estado legislador? Disponível em: http://www.javeriana.edu.co/juridicas/pub_rev/documents/4Sarmiento.pdf. Acesso em 17.10.09, p. 94. e também Cf. ENTERRÍA, Eduardo García de. La responsabilidad patrimonial del Estado Legislador en el Derecho español. 2. ed. Navarra: Civitas, 2007, p. 46.

373 "El poder legislativo no puede ser obstaculizado en sus disposiciones por la perspectiva de una acción indemnizatoria cada vez que se encuentra en el caso de adoptar, en consideración al interés general, medidas normativas susceptibles de causar perjuicios a los intereses de los particulares". Citado por ENTERRÍA, Eduardo García de. Op. cit., p. 46.

${ }^{374}$ GARCÍA MACHO, R. Contenido y limites del principio de la confianza legítima: estudio sistemático en la jurisprudencia del Derecho Comunitario. Revista española de Derecho Administrativo, n. 56, 1987, p. 571 et. seq. Apud SARMIENTO-ERAZO, Juan Pablo. La vulneración a la confianza legítima. ¿Una situación jurídica generadora de responsabilidad del Estado legislador? Disponível em: http://www.javeriana.edu.co/juridicas/pub_rev/documents/4Sarmiento.pdf. Acesso em 17.10.09, p. 95.
} 
momento de uma operação determinada. Mas ainda nesse caso sustentou que um interesse público peremptório poderia legitimamente passar por cima desse princípio ${ }^{375}$.

Do que se observa da experiência espanhola e da Comunidade Europeia, não se poderia invocar o princípio da proteção à confiança como um limite aplicável em face do legislador, pois deve haver ampla liberdade para que este possa determinar sua opção de política econômica, para que não ocorra o congelamento do Direito.

Na Espanha, porém, somente em situações em que lei posterior modifica a lei que fomentava um determinado comportamento do particular, incitando-o a fazer investimentos, pode-se falar em responsabilidade civil estatal, não obstante haja vozes discordantes desse posicionamento na doutrina do referido país, como já referido.

No direito brasileiro, sem adentrar no aspecto relativo à proteção à confiança que os particulares possuem em face da atuação estatal, Carlos Maximiliano já em 1946 ensinava que a expectativa jurídica - que pode ser entendida como um direito que já começou a se realizar, mas que ainda falta-lhe algum requisito para se completar - não recebe proteção jurídica, podendo a lei suprimi-la ou mesmo retroagir para desfazer as possibilidades ou expectativas existentes em virtude da lei anterior ${ }^{376}$.

Não se poderia, assim, defender o dever de manutenção de um agir de determinada maneira por parte do Estado Legislador em virtude de uma confiança legítima ou a boa-fé que os cidadãos possam ter na manutenção desse comportamento ${ }^{377}$. Expectativas legitimamente criadas, em regra, não poderiam ser opostas ao legislador, nem poderiam amparar um pedido de indenização, dada a natureza cambiante e própria dessa atividade, somada aos grandes encargos que adviriam para o Estado em virtude tal posicionamento, conduzindo mesmo, ao final, à inviabilidade de sua atuação.

Tal conclusão, entende-se, no entanto, não se mostraria como uma solução universal e invariável, colocando-se apenas como um parâmetro aberto a admitir as necessárias ponderações das circunstâncias concretas, que reclamariam a análise sempre da motivação dos atos legislativos, pela qual se poderia auferir a razoabilidade e a

\footnotetext{
${ }^{375}$ Citado por ENTERRÍA, Eduardo García de. La responsabilidad patrimonial del Estado Legislador en el Derecho español. 2. ed. Navarra: Civitas, 2007, p. 48.

${ }^{376}$ MAXIMILIANO, Carlos. Direito Intertemporal ou teoria da retroatividade das leis. Rio de Janeiro: Freitas Bastos, 1946, p. 46.

${ }^{377}$ Frise-se tratar aqui da não aplicação de tal princípio frente ao legislador parlamentar, ao que não se refere aos demais atos estatais.
} 
proporcionalidade do ato e de sua congruência com os princípios materiais da Constituição. Renunciar a uma análise do caso concreto, afastando a variedade e a multiplicidade de fatos da vida social que se desenrolam sob a atividade legislativa do Estado seria desembocar na absoluta iniquidade do Direito. A solução, portanto, há de considerar as características da lei e da situação concreta, a ser apurada a partir dos interesses envolvidos, ponderados os princípios em jogo.

Por isso é que, se de modo geral não se pode obstar que o legislador modifique um ato legislativo criador de uma expectativa de vantagem para o particular, por outro lado há de se reconhecer que certos atos legislativos pretendem o engajamento da iniciativa privada para lograr seus fins, de maneira que se constituem em promessas firmes, destinadas a captar a adesão dos particulares que criam expectativas em relação à sua realização, razão pela qual a posterior modificação pelo Estado dessas promessas pode resultar danosa, caracterizando-se como um prejuízo anormal e especial.

A questão torna-se espinhosa na seara econômica, pois, após a eclosão do Estado Providência, designado a comandar a atividade dos indivíduos e dos grupos, a lei veste não mais uma simples atitude passiva de prevenir e solucionar os conflitos decorrentes da competição entre os grupos e os indivíduos em busca de seus interesses, mas dispõe-se também a uma postura impulsionadora, de foco de irradiação do desenvolvimento, o que a torna, por isso, um instrumento para interferência na economia, destinado a criar expectativas nos particulares.

Fernando Facury Scaff ${ }^{378}$ distingue, embora advirta tratar-se de uma distinção muito sutil, que o Estado pode fazer dois tipos de normas (incluindo aí qualquer forma de expressão normativa, tais como leis, medidas provisórias, portarias, regulamentos, regimentos, etc.) quando atua sobre o domínio econômico: a) normas de direção: que não permitem outro comportamento a não ser o previsto na norma, tal como o tabelamento de preço fixado para comercialização de certa mercadoria; b) normas de indução: nas quais o Estado não determina procedimentos incisivos e coativos a serem adotados pelos agentes econômicos, mas orienta-os no sentido de adotar aquelas opções que se tornarem economicamente mais vantajosas. Através das normas de indução o Estado também poderia desestimular uma atividade econômica e não apenas incentivá-la (quando o Estado,

378 SCAFF, Fernando Facury. Responsabilidade civil do Estado intervencionista. 2. ed. Rio de Janeiro: Renovar, 2001, pp. 106-110. 
por exemplo, determinasse altas alíquotas de impostos de importação na hipótese de entrada de automóveis).

Lúcia Valle Figueiredo ${ }^{379}$ aduz que não apenas no campo da intervenção econômica, mas em toda a atividade estatal de planejamento, o que inclui o planejamento urbano, poderia se cogitar de atitudes incitativas do Estado, geradoras de expectativas que, modificadas, ensejariam a responsabilidade civil estatal.

A citada autora aduz, no entanto, que não são todos os planos que levariam à responsabilidade, por isso perfaz uma classificação destes, de modo a indicar-lhes as características, dividindo-os em planos indicativos, incitativos e imperativos. Os primeiros corresponderiam àqueles em que o Governo apenas assinala em alguma direção, sem qualquer compromisso, sem pretender o engajamento da iniciativa privada, de modo que a sua posterior alteração não ensejaria qualquer direito a reparação. Já os planos incitativos seriam aqueles em que o Governo não apenas sinaliza, mas pretende também o engajamento da iniciativa privada. Nesses ocorreriam promessas de variadas medidas por parte do ente estatal, quer por meio de incentivos ou de qualquer outra forma para que a iniciativa privada colabore. Por causa disso, os particulares que aderem aos planos contam com a confiança, a boa-fé e a lealdade do Estado na sua manutenção. Se modificações advierem, certamente poderão resultar em prejuízos e ensejar o pagamento de uma indenização - a depender, é claro, do dano (prejuízo certo, especial e anormal), da conduta estatal e do lesado, da inexistência de nenhuma excludente de responsabilidade. Do mesmo modo ocorreria com os planos imperativos, os quais se caracterizariam pela necessária observância $^{380}$.

Nesse campo em especial, Almiro do Couto e Silva também defende a aplicação do princípio da boa-fé a fundamentar a responsabilidade do Estado. Para o autor, nos casos em que o Estado modifica um plano econômico, que não é meramente informativo, mas sim tem feição incitativa, em cuja implantação ou execução o Estado se compromete firmemente a propiciar benefícios de qualquer natureza, inclusive de índole fiscal, poderá se falar em responsabilidade. Decisivo para tanto será observar se as promessas foram realmente firmes, precisas e concretas. Daí que, para o autor, caso as promessas tenham se

\footnotetext{
${ }^{379}$ FIGUEIREDO, Lúcia Valle. O devido processo legal e a responsabilidade do Estado por dano decorrente do planejamento. Revista de Direito Administrativo. Rio de Janeiro: Renovar, v. 206, pp. 89-107, out./dez., 1996, p. 98.

${ }^{380}$ Ibidem, p. 98
} 
revestido dessas características, a alteração posterior do plano, ainda que efetuada mediante lei, implica o dever de indenizar os danos decorrentes da confiança, abrangendo, à semelhança do que sucede no Direito Privado, em princípio, apenas a reparação do interesse negativo e não dos lucros que o particular teria caso fossem mantidas as mesmas condições.

No entanto, segundo o referido doutrinador, embora tal responsabilidade exista, ela se afirmará em função das peculiaridades das situações concretas, sempre que o Estado causar dano ao violar os deveres decorrentes da boa-fé, infringindo o princípio de que ninguém pode impunemente venire contra factum proprium, depois de haver estimulado, com promessas firmes de vantagens, um determinado comportamento ${ }^{381}$.

Essas situações corresponderiam, entende-se, a hipóteses excepcionais e que não poderiam ser aplicadas a todo e qualquer caso, dada a necessária característica de cambialidade da legislação, razão pela qual poderiam ser encaradas como uma preciosidade, da qual não se poderia servir todos os dias, sob pena de inviabilizar a atividade legislativa.

É certo que, como bem pondera Leila Cristina Garbin Arlanch, a emanação legislativa de um plano deve ser precedida de profundo diagnóstico da situação que o mesmo vai disciplinar ${ }^{382}$. É cabível exigir da Administração - também do Legislador - o exato conhecimento das suas possibilidades a fim de evitar que, através de promessas não mantidas, leve os particulares a compromissos e a riscos que eles não dominam e que não correriam não fossem as garantias dos entes públicos ${ }^{383}$. Ocorrendo uma alteração do plano por erro do Estado, se terá, por certo, a responsabilidade estatal com base na falha da função pública.

Mas é certo também que a modificação das circunstâncias fáticas pode obrigar a alteração do plano. Daí que essa necessária modificação também pode provocar prejuízos, uma vez que nessas circunstâncias o Estado incitou o particular a um determinado

381 Cf. COUTO E SILVA, Almiro. Responsabilidade do Estado e problemas jurídicos resultantes do planejamento. Revista de Direito Público, São Paulo, n. 63, pp. 28-36, 1982, pp. 33-34.

382 ARLANCH, Leila Cristina Garbin. Responsabilidade patrimonial extracontratual do Estado por danos decorrentes de planejamento urbanístico e licenças urbanísticas. Revista dos Tribunais. São Paulo, v. 81, n. 677, pp. 43-58, mar./1992, p. 52.

${ }^{383}$ FIGUEIREDO, Lúcia Valle. O devido processo legal e a responsabilidade do Estado por dano decorrente do planejamento. Revista de Direito Administrativo. Rio de Janeiro: Renovar, v. 206, pp. 89-107, out./dez., 1996, p. 101. 
comportamento e, pelo princípio da confiança que este deposita na atividade estatal, poderá exigir uma medida indenizatória correspondente ao prejuízo sofrido. Avulta a necessidade, contudo, de demonstração cabal pelo particular da promessa firme e da falta de seu cumprimento por parte do ente estatal. Não obstante a indispensabilidade de mudança do plano, não se pode deixar que alguns sofram um prejuízo especial e anormal em proveito da sociedade, de modo que o princípio da repartição dos ônus e encargos públicos impõe a necessidade de compensação financeira por parte do ente estatal.

É certo, porém, que nessas hipóteses haverá que se atentar para o comportamento da vítima, ou seja, se esta agiu com o nível de prudência que lhe é razoável exigir. Por certo, deve se considerar que um comerciante probo está atento às necessidades evolutivas da política econômica realizada através de atos normativos abstratos, razão pela qual, a depender das circunstâncias, pode se constituir numa excludente ou atenuante da responsabilidade civil estatal, já mencionadas no capítulo 1 da Primeira Parte deste trabalho.

2.2.2.5. A legitimidade de afastamento da proteção ao direito adquirido e as expectativas legitimamente criadas por parte do legislador

Como se observou no item anterior deste capítulo, o ordenamento pátrio acolhe a proteção ao direito adquirido, ao ato jurídico perfeito e à coisa julgada como direitos fundamentais, impondo-os como matriz conformadora do processo legislativo, inclusive quanto aos processos de revisão ou reforma constitucional.

Também em determinadas situações, quando o Estado incita o particular com promessas firmes, pode-se exigir que este cumpra tais promessas, na medida em que os particulares confiam na sua manutenção e, por isso, adequam suas condutas para concretização do plano editado pelo Estado.

Entretanto, como aduzido no Capítulo 2 da Primeira Parte deste trabalho, há hipóteses em que é legítimo - a própria ordem jurídica autoriza - que o Estado realize o esgarçamento de um determinado direito - acrescente-se: de uma situação de confiança fundada, nas hipóteses delineadas no item anterior -, produzindo um dano lícito na esfera jurídica do indivíduo, ao que não corresponde, contudo, uma imunidade estatal, mas sim um dever de efetuar o pagamento do equivalente patrimonial desse direito ou expectativa. 
A possibilidade de esgarçamento de um direito também é aplicável ao direito que foi adquirido, ou seja, existe a possibilidade de que em determinadas circunstâncias afastese a proteção em face da atuação legislativa dos direitos que se incorporaram ao patrimônio do indivíduo, mas que ainda não tenham sido exercidos, de modo a fazer prevalecer outro princípio que se traduza na defesa da justiça. A negativa de aplicação do princípio da estabilidade, todavia, não retira sua força, sua obrigatoriedade ou validade; a norma principiológica continua fazendo parte do ordenamento, na iminência de ser aplicada a qualquer outro caso que a possa atrair $^{384}$. O raciocínio também se aplica às hipóteses em que se tem uma expectativa induzida pelo Estado, nas situações elencadas anteriormente.

A legitimidade, contudo, desse esgarçamento somente pode ser auferível de acordo com razões de interesse público, respeitados os princípios da razoabilidade e proporcionalidade do ato, auferidos de acordo com a motivação elaborada. Vale aqui, portanto, trazer à colação um pouco da operação intelectiva que hoje se faz sobre a expressão interesse público, sem o que não se poderia avançar de modo apropriado.

\subsection{O interesse público legitimador desse afastamento}

Por certo que, num Estado Constitucional, o interesse púbico que deve ser perseguido pelo legislador é aquele que está de acordo com as vinculações de ordem material consagradas na Carta Maior. Ainda que esta se utilize de conceitos abertos, é o sistema de valores e princípios materiais que explícita ou implicitamente encontram-se dispostos em suas normas que balizará e limitará a discricionariedade legislativa.

A identificação desse interesse público, no entanto, é uma tarefa que suscita debate entre os juristas, especialmente porque diante da utilização de conceitos jurídicos indeterminados pela Constituição, bem como diante da própria fluidez da expressão, não é possível o seu reconhecimento de forma objetiva, o que não se traduz, no entanto, num defeito, mas num atributo adequado do sistema normativo à riqueza do mundo real.

Postula-se hoje que o interesse público não mais se confunde com o interesse da maioria, dada a impossibilidade de se localizar uma maioria propriamente dita, com cunho de permanência. Vive-se atualmente numa sociedade marcada pela diversidade, cuja

\footnotetext{
${ }^{384}$ PIRES, Maria Coeli Simões. Direito adquirido e ordem pública: segurança jurídica e transformação democrática. Belo Horizonte: Del Rey, 2005, p. 615.
} 
característica revela a inexistência de um povo que se expressa em uníssono, havendo interesses cada vez mais divergentes e complexos, e em constante mutação. Não existe um conjunto suficientemente homogêneo de interesses privados ao qual se possa atribuir a condição de interesse da maioria, de modo que a adoção do critério quantitativo nem resolve nem é suficiente para a identificação do interesse público. Compreende-se, assim, que o ato legislativo constitucional, ao qual se reconhece a perseguição de um determinado interesse público, não merece essa rubrica simplesmente porque tem por finalidade o atendimento de um interesse de um grande número de pessoas. Existem interesses que não são gerais e continuam a ser públicos.

Do mesmo modo também não se vincula o interesse público como sendo aquele perseguido pelo Estado, haja vista que não mais subjaz a ideia de que o interesse é definido a partir da identidade do seu titular. Reconhece-se que o conceito de interesse público é anterior ao conceito de Estado, ou seja, existem interesses públicos que podem ser titularizados por pessoas privadas, como, por exemplo, os denominados interesses públicos não-estatais, tais quais os defendidos pelas organizações não-governamentais (ONGs).

A identificação do interesse público atualmente exige mais do que o simples fato de ser perseguido pelo Estado. A tendência atual reconhece como interesse passível de ser defendido perante outros interesses aquele que é apurado por meio da participação da sociedade em seu processo de formação, onde a decisão final resulta da observância das etapas procedimentais, com a garantia do contraditório e segundo uma atuação imparcial. Como explica Marçal Justen Filho ${ }^{385}$ :

[Hoje] A autoridade estatal não pode impor certa solução, afirmando ser a que traduz o interesse público, sem observar os princípios procedimentais e processuais cabíveis. Especialmente quando se considerar um Estado pluriclasse, é imprescindível dar oportunidade de manifestação a todos os grupos e centros de interesse. A adequação da decisão final resulta da observância das etapas procedimentais, com garantia de contraditório e segundo uma atuação imparcial.

No entanto, não apenas o crivo democrático compõe-se no signo de legitimação das decisões estatais - ainda que em sede legislativa -, entendidas estas como as que se adequam ao interesse público. Compreende-se que no momento histórico vivido, as opções estatais legítimas são aquelas que estão voltadas à consagração dos princípios fundamentais constitucionalmente apontados, de modo que o exercício do poder deve estar

${ }^{385}$ Conceito de interesse público e a "personalização" do direito administrativo. Revista Trimestral de Direito Público. São Paulo, n. 26, pp. 115-136, 1999, p. 132. 
objetivamente voltado para tanto. Ainda que se considere existir uma vasta escala de graus de vinculação dos atos estatais em relação às normas constitucionais, já que estas não se constituem em enunciações fechadas, reconhece-se caber ao Estado adotar as medidas que estejam de acordo com o compromisso valorativo dos direitos fundamentais, dos quais não se extrai apenas um limite para não agir em desacordo com eles, mas um atuar positivamente, de forma comprometida com o resultado.

O princípio da dignidade da pessoa humana passa, portanto, a ser entendido como centro irradiador de significado para a ideia de interesse público, o que resulta na impossibilidade de não realização desse interesse, isto é, a relação entre o princípio da dignidade da pessoa humana e o interesse público converge para a obrigatoriedade de sua realização, diferentemente do que corre com um interesse privado, o qual é guiado pelo princípio da liberdade, de modo que o indivíduo pode resolver pela sua realização ou não, dado que não se vincula com a dignidade da pessoa humana ${ }^{386}$.

São essas mesmas características que, compondo a qualidade do interesse como público, identificam a sua relevância e reclamam sua imperiosa realização. Por isso, é atribuído ao Estado de forma preponderante, posto que, precisamente pela relevância da dignidade da pessoa humana, não se poderia deixar a satisfação desse valor fundamental ao sabor da iniciativa particular e individual. Atribuindo-o ao Estado, o reconhecimento de sua atividade como legítima conduzirá necessariamente ao entendimento de que outros interesses privados podem deixar de ser realizados e satisfeitos.

Daí falar-se, com temperamento, na possibilidade de sacrifício legítimo, de forma total ou parcial, de um direito ou de uma expectativa criada através de uma conduta incitativa do Estado, dada a necessidade de vulnerar em menor grau o valor desatendido, por força do princípio da proporcionalidade.

Há que se ressaltar, no tocante especificamente à possibilidade e legitimidade de vulneração de um direito adquirido de acordo com o interesse público invocado, o desenvolvimento do tema - dos critérios que devem ser levados em conta pelo julgador do caso concreto a fim de afastar legitimamente ou admitir a configuração do direito adquirido - pelo jurista francês Constantin Yannakopoulos, cujo parâmetro embasou a sugestão feita por Maria Coeli Simões Pires, em amplo estudo que procedeu a respeito do

\footnotetext{
${ }^{386}$ Conceito de interesse público e a "personalização" do direito administrativo. Revista Trimestral de Direito Público. São Paulo, n. 26, pp. 115-136, 1999, p. 136.
} 
confronto entre direito adquirido e normas de ordem pública. Esse estudo aponta que as noções ampla e restrita de interesse público, apropriadas ao campo específico de aplicação, podem conduzir o juiz, no caso concreto, respectivamente, a afastar ou a admitir a configuração de direito adquirido, isto é, a noção ampla favorece a Administração em face da posição individual, enquanto a noção estrita protege o $\operatorname{particular}^{387}$.

A definição do interesse público de forma particularizada repercutiria categoricamente quanto à amplitude de proteção ao direito adquirido, de modo inversamente proporcional, ou seja, quanto maior a amplitude do interesse público invocado pelo Estado, mais justificada estaria a retirada de uma autorização, por exemplo, menor restaria o direito do particular ${ }^{388}$. Daí que, caso não se reconheça o direito, logo não se vislumbra a possibilidade da correspondente indenização, razão pela qual, nesse caso em específico, de acordo com a caracterização do interesse público, sem prejuízo da análise de outros critérios, haveria um papel mais proeminente na aplicação do dever de indenizar.

De todo o exposto, observa-se que é legítimo uma lei poder, com base na configuração do interesse público tal qual aludido, bem como se levando em conta a necessidade e adequabilidade da medida, afastar direitos e expectativas criadas por uma atitude incitativa do Estado, sacrificando-os total ou parcialmente. Plenamente possível, portanto, a existência de uma lei constitucional danosa, prejudicial a um direito ou expectativa do indivíduo.

Cabe ressaltar, contudo, que a alteração legislativa - e não se poderia deixar aqui de destacar que a supressão do direito, a modificação de um plano incitativo que importou em expectativas legítimas do particular somente assim permanecerá nos lindes da competência discricionária do legislador - deve ser razoável, motivada e proporcional $^{389}$.

É certo que através da motivação se terá o discurso justificativo da decisão contida no ato, não apenas com a exposição dos motivos de fato e de direito, mas em todos os seus

\footnotetext{
387 YANNAKOPOULOS, Constantin. La notion de droits acquis en droit administratif français. Paris: L.G.D.J, 1997, p. 203. Apud PIRES, Maria Coeli Simões. Direito adquirido e ordem pública: segurança jurídica e transformação democrática. Belo Horizonte: Del Rey, 2005, p. 645.

${ }^{388}$ Ibidem, p. 645.

${ }^{389}$ FIGUEIREDO, Lúcia Valle. O devido processo legal e a responsabilidade do Estado por dano decorrente do planejamento. Revista de Direito Administrativo. Rio de Janeiro: Renovar, v. 206, pp. 89-107, out./dez., 1996, p. 102.
} 
aspectos de legalidade, oportunidade e conveniência ${ }^{390}$. Pela motivação do ato é que se constatarão as suas razões, se auferirá o devido processo que culminou com a decisão legislativa de modificação da situação então existente, a verificação, no caso concreto, do atendimento do interesse público tal como afirmado. Daí que restará justificado e será possibilitada a defesa da legitimidade do ato com a exposição dessas justificativas, ou seja, com a motivação.

Também para que se possa ter por legítimo o esgarçamento, este deve atender ao senso de razoabilidade, ou seja, não pode ser arbitrário, caprichoso, mas deve supor um equilíbrio, ser moderado de acordo com os valores vigentes em dado momento e lugar. Há necessidade de que a modificação trazida pela lei seja uma exigência compatível com o fim buscado e que, ainda, esses fins sejam legítimos, preconizados pelo texto constitucional ${ }^{391}$.

No mais, é necessário que a modificação legislativa observe o princípio da proporcionalidade, sendo adequada (o meio apto a alcançar o fim pretendido), necessária (não se possa, por outro meio, atingir o mesmo objetivo) e proporcional (haja um sopesamento da intensidade da restrição com a importância da realização do direito fundamental que com ele colide) $)^{392}$.

Feitas tais considerações a respeito do legítimo esgarçamento do direito ou da situação em que há confiança fundada, importa agora adentrar na questão da necessidade de prévia indenização pelo legítimo esgarçamento ou de responsabilidade, quando o prejuízo decorrer indiretamente do ato legislativo.

A respeito da definição de sacrifício, por certo já se anunciou os critérios que permitem o seu balizamento em capítulo anterior, razão pela qual se torna despiciendo repeti-los aqui, valendo apenas a observação de que as leis podem qualificar-se como desapropriatórias quando ferirem - retirarem - o conteúdo essencial de um direito patrimonial, atingindo direitos de forma especial e anormal.

\footnotetext{
${ }^{390}$ Cf. CINTRA, Antônio Carlos de Araújo. Motivo e motivação do ato administrativo. São Paulo: Revista dos Tribunais, 1979, p. 107.

391 BARROSO, Luis Roberto. Os princípios da razoabilidade e da proporcionalidade no direito constitucional. Revista Forense. Rio de Janeiro, v. 92, n. 336, pp. 125-136, out./dez. 1996, pp. 129 - 130.

392 SILVA, Luís Virgílio Afonso da. O proporcional e o razoável. São Paulo. Revista dos Tribunais, v.91, n. 798, pp. 23-50, abr. 2002, p. 34 et. seq.
} 


\subsubsection{O dever de previsão de indenização e a responsabilidade}

Como já referido, é a própria Constituição que, ao mesmo tempo em que outorga poderes ao legislador, possibilitando que através de sua atuação se estabeleça o delineamento jurídico de direitos que ela consagra, trazendo conteúdo para garantia da dignidade da pessoa humana, também estabelece limites para essa atuação.

Como já abordado no Capítulo 2 da Primeira Parte deste trabalho, o Estado pode, mediante a prática de atos legislativos ou administrativos, legitimamente aniquilar o direito alheio, quando se fizer indispensável e se tratar da medida adequada para realização do interesse público. No entanto, nesses casos subsiste a obrigação estatal de prever e pagar o equivalente patrimonial desse direito. Se por um lado provoca-se de forma lícita o prejuízo, admitido pelo ordenamento jurídico, por outro esse somente será legítimo se obedecer ao requisito da previsão de indenização, sob pena de flagrante desrespeito à Carta Maior. Em sendo desrespeitado, por certo surgirá a oportunidade de aplicação do artigo $37, \S 6^{\circ}$, da Constituição Federal, que consagra a responsabilidade estatal de forma objetiva e, como já se observou anteriormente, não apenas tem natureza reparatória mas também sancionatória.

Disso deflui que o sacrifício de direito realizado através de um ato legislativo exigiria que o próprio legislador previsse essa indenização na norma jurídica que edita, levando-se em consideração que o ato está legitimamente direcionado ao aniquilamento de um direito e, por isso, indiscutivelmente, causará um dano. Tratando-se de dano certo e não eventual, que atinge uma situação jurídica legitima, importando numa vulneração do princípio da igualdade, dada a especialidade do prejuízo e que, por certo, constituiria uma forma anormal de afetação do direito, posto que não se trataria de mero condicionamento do seu exercício, mas de uma forma de afetação que atingiria o seu conteúdo, não haveria fundamento jurídico que autorizasse o legislador a ignorar esse dever, dado que decorre das normas constitucionais que instituem e garantem os direitos aos cidadãos e a igualdade na repartição das cargas públicas.

Vale observar, todavia, que essa possibilidade do legislador estatuir, no próprio ato normativo que edita, o dever estatal de prestar indenização para determinadas hipóteses em que produz um dano querido já foi analisada pela doutrina como hipótese de responsabilidade civil. E, como tal, foi compreendida como fator determinante da responsabilidade estatal, de modo que não poderia o Poder Judiciário modificar o 
entendimento expresso na lei, ou seja, seria o posicionamento do legislador que possibilitaria a responsabilidade: se a indenização é reconhecida através do próprio ato legislativo, logo não haveria dúvida quanto à possibilidade do Estado ressarcir o particular que tenha sofrido um dano causado pelo ato legislativo. No entanto, se o legislador silenciasse em relação a esse direito, não caberia a satisfação do dano, porventura resultante das suas leis e resoluções ${ }^{393}$, sob pena de ocorrer uma intromissão indevida do Judiciário na esfera de atuação legítima do Poder Legislativo.

Porém, não seria pertinente compartilhar tal posição, visto que, como já analisado ao longo deste estudo, não se confundem as hipóteses de responsabilidade e o dever subsidiário de indenização decorrente de um legítimo sacrifício de direito. Ademais, não se mostra compatível com um Estado constitucional tratar a indenização como uma opção discricionária do legislador, posto configurar um dever decorrente da situação de invulnerabilidade dos direitos consagrados pela Carta Maior. Nesse sentido, como já advertiram Canotilho e Vital Moreira, se as leis danosas "excluírem expressamente a responsabilidade patrimonial do Estado, é legítimo sempre levantar o problema da sua inconstitucionalidade" ${ }^{, 394}$.

Com efeito, o princípio da supremacia das normas constitucionais requer que todas as situações jurídicas se conformem com os princípios e regras do Texto Fundamental. Por certo que a noção de supremacia não se exaure com a promulgação da Carta de Base, apenas se transfere para a prática constitucional cotidiana, para o campo da interpretação e aplicação de suas normas. Por isso, cabe a todo e qualquer operador e, especialmente, a qualquer órgão ou agente estatal, observá-la por ocasião de sua atuação comissiva ou omissiva, sem o que essa supremacia é reduzida a uma enunciação vazia.

O legislador, assim, deve estar predisposto a concretizar no plano normativo operacional esse princípio, resguardando os direitos e as garantias fundamentais presentes na Carta Maior. Essa estrita observância não se opera, simplesmente, quando não se faz o

\footnotetext{
${ }^{393}$ Esse é o posicionamento de Amaro Bezerra Cavalcanti: "A irresponsabilidade pelos atos legislativos é afirmada de modo absoluto: êstes atos não podem dar lugar a nenhuma ação contra o Estado nem contra as pessoas dos legisladores que hajam tomado parte na sua adoção. Se bem que o legislador deva proceder com a máxima prudência, evitando sempre ofender aos interesses privados; todavia, se assim não fizer e ferir realmente esses interesses ou direitos, é ao próprio legislador que cabe o livro arbítrio de conceder, ou não, a satisfação do dano, porventura resultante das suas leis e resoluções". CAVALCANTI, Amaro Bezerra. Responsabilidade civil do Estado. (Atual. José de Aguar Dias). v. 2. Rio de Janeiro: Borsoi, 1957, pp. 444445.

${ }^{394}$ CANOTILHO, José Joaquim Gomes. MOREIRA, Vital. Constituição da República portuguesa anotada. v. 1. 2.ed. Coimbra: Coimbra, 1984, p. 186
} 
que norma constitucional proíbe, mas também quando se realiza concretamente o que ela determina e do modo como ela determina.

Por certo, todavia, que as descrições abstratas, o conteúdo axiológico, o traço não exaustivo que hoje toma conta dos textos constitucionais torna ainda mais difícil distinguir aquilo que se encontra posto à conveniência e oportunidade do legislador - e que deve ser prezado - daquilo que está numa zona de certeza positiva de atuação.

Todavia, hodiernamente, se por um lado há a adoção de cláusulas bastante abertas no texto constitucional, que buscam expressar os valores da sociedade, por outro a noção de supremacia constitucional incorporada progressivamente à consciência jurídica da civilização ocidental ao longo dos anos desperta, nos responsáveis pela interpretação das normas jurídicas, a noção de que todos os seus comandos podem impor tarefas passíveis de concretização, independentemente das objeções de conveniência e oportunidade.

Há que se ressaltar que o campo da discricionariedade não é mais compreendido como um espaço aberto a escolhas puramente subjetivas - nem para o âmbito administrativo, nem para o âmbito legislativo -, tendo sido alicerçados, ao longo dos anos, limites para a sua configuração, sendo o mais recente deles o decorrente da incidência dos princípios - tanto constitucionais quanto legais ${ }^{395}$ - a pautar essa margem de liberdade. Nesse sentido, é preciso afirmar que o delineamento constitucional, se não é uma reserva total, nem um bloco densamente vinculativo que torne o legislador um mero executor, não permite também o arbítrio, o próprio descompromisso para com o seu texto, razão pela qual se pode concluir, com Vanice Regina Lírio do Valle, que o comportamento omissivo é deslegitimado quando a abstenção entra em confronto com o próprio traçado constitucional, prejudicado em sua efetividade pela omissão ${ }^{396}$.

A análise da legitimidade de um ato perante os comandos constitucionais passa, nesse contexto, não somente pela observância de competências formais, mas pela análise de como a atuação - ou omissão de atuação -, e no caso interessa aqui a atuação legislativa, impede a eficaz aplicação de um preceito constitucional. Compreende-se, hoje, que a legitimidade de um ato legislativo, num sentido amplo, atravessa o critério de

\footnotetext{
395 Sobre as etapas da evolução do controle da discricionariedade, como instituto de direito, confira-se o Capítulo V da obra de BINENBOJM, Gustavo. Uma teoria do Direito Administrativo. Rio de Janeiro: Renovar, 2006, pp. 193-238.

396 VALLE, Vanice Regina Lírio do. Sindicar a omissão legislativa: real desafio à harmonia entre os poderes. Belo Horizonte: Fórum, 2007, p. 165.
} 
aferição valorativa, ou seja, passa pela investigação de como uma atuação ou uma abstenção culmina por erodir o quadro de valores constitucionais, fazendo pouco caso da supremacia de suas normas ${ }^{397}$.

Não apenas o enunciado normativo presente no texto constitucional deve ser considerado para fins de categorização da inconstitucionalidade por omissão, mas também uma avaliação das consequências dessa ausência: há que se analisar se ela impede a eficaz e completa aplicação do preceito constitucional não desenvolvido, como forma mesmo de reiterar uma supremacia constitucional integral.

Investiga-se especificamente o silêncio do legislador e identificam-se tanto as hipóteses em que ocorre uma omissão legislativa total, ou seja, quando há uma absoluta falta de ação em face do dever jurídico de agir, quanto as situações de omissão legislativa parcial, circunstância em que ocorre uma atuação legislativa insuficiente a cumprir de forma adequada o comando do Texto Fundamental.

Recentemente tem-se o reconhecimento expresso da sindicabilidade da omissão legislativa parcial através das alterações procedidas pela Lei 12.063/2009 na Lei 9.868/99, nos seus artigos 12 e seguintes, a qual, prevendo o procedimento relativo à Ação Direta de Inconstitucionalidade por omissão, incluiu a possibilidade de manejo da referida ação quando existir uma omissão inconstitucional total ou parcial (artigo 12 - B, inciso I).

A doutrina identifica, ainda, no âmbito da omissão parcial, a existências de duas espécies dessa categoria: a omissão parcial relativa e a omissão parcial propriamente dita. A primeira circunscreve-se à hipótese em que a lei exclui do seu âmbito de incidência determinada categoria que nela deveria estar abrigada, por força do princípio da isonomia. É o caso da lei que concede privilégios ou impõe determinados ônus a certa categoria de pessoas, mas não a todas aquelas que, estando em situação idêntica, deveriam ser contempladas de igual modo ${ }^{398}$. Cite-se, como exemplo, o julgamento proferido pelo

\footnotetext{
${ }^{397}$ Vanice Regina Lírio do Valle destaca que num sistema identificado com o constitucionalismo de direitos, o controle do exercício do poder político (e, portanto, a investigação de sua legitimidade num sentido mais amplo) há de passar a compreender igualmente essa possibilidade de aferição valorativa. Além disso, essa amplitude de investigação e ação há de determinar uma revisão da velha assertiva de que se possa conceber a modelagem do exercício do controle do poder como reconhecimento de supremacia em favor de um deles. A premissa dogmática da supremacia de um dos poderes impede aprioristicamente a avaliação valorativa de seu atuar, corroendo as fundações da nova concepção de constitucionalismo. Cf. VALLE, Vanice Regina Lírio do. Op. cit., p. 142.

${ }^{398}$ PUCCINELLI JÚNIOR, André. A omissão legislativa e a responsabilidade do Estado legislador. São Paulo: Saraiva, 2007, p. 125.
} 
Supremo Tribunal Federal na ADIn 529-DF, que reconheceu a inconstitucionalidade omissiva da Medida Provisória 296/91, que não estendeu à totalidade do pessoal civil da União, os benefícios concedidos aos servidores federais nela contemplados, em desrespeito ao artigo 37, inciso X, da Constituição ${ }^{399}$.

Por sua vez, configura-se a inconstitucionalidade por omissão parcial propriamente dita quando o texto normativo editado não afeta o princípio da isonomia, mas é em si insuficiente para conferir densidade normativa concretizadora do preceito constitucional. Tipicamente, cita-se como exemplo a lei de fixação do salário mínimo, em valor que não satisfaz a exigência constitucional prevista no artigo $7^{\circ}$, inciso IV, da CF, hipótese em que foi reconhecida a omissão parcial do legislador pela mais alta cúpula do Poder Judiciário $^{400}$.

Em face do exposto pode-se agora analisar a imprescindibilidade da previsão de indenização no ato legislativo que tem por finalidade a realização de um legítimo sacrifício de direito - ou sacrifício de expectativas legítimas que foram incitadas pelo Estado.

Como já se analisou no capítulo anterior, os sacrifícios de direitos conduziriam a uma diminuição, suspensão ou eliminação das possibilidades de desfrute genericamente admitidas pelo ordenamento ao direito de propriedade (direito já adquirido) e, em razão disso, aliado a outros critérios como o da generalidade e da singularidade, por meio dos quais se busca o respeito ao princípio da igualdade, acarretariam o direito à indenização.

Ao se considerar de forma ampla a acepção do direito de propriedade, de modo a abranger qualquer direito subjetivo patrimonial do indivíduo, bem como levando em consideração que não apenas os atos que realizam a transferência da titularidade do domínio, mas também os que procedem a vulneração do conteúdo do direito, deveriam se submeter ao regime expropriatório, por certo que no caso das leis que visam instituir esse mesmo tipo de sacrifício de direito procederiam a uma omissão legislativa inconstitucional (parcial) caso não previssem a correspondente indenização pelo aniquilamento do direito, já que abririam um espaço para, além da violação do dever de igualdade (um dos

\footnotetext{
${ }^{399}$ STF. ADIN 529-DF, Relator: Ministro Sepúlveda Pertence. Julgado em 19.06.1991. DJ 05.03.1993. Disponível em http://www.stf.jus.br/portal/jurisprudencia/listarJurisprudencia.asp. Acesso em 28.02.2009. ${ }^{400}$ STF. ADIN 1458-7. Relator: Ministro Sepúlveda Pertence. Tribunal Pleno. Julgado em 26.05.96. DJ 20.09.96. Disponível http://www.stf.jus.br/portal/inteiroTeor/obterInteiroTeor.asp?numero=1458\&classe=ADI-MC. Acesso em: 28.02.09.
} 
fundamentos do dever de indenização, nas hipóteses de sacrifício e também do instituto da responsabilidade), também uma afronta ao próprio direito, que restou desmerecido, em desacordo com a ordem jurídica.

Sendo a indenização o símbolo do respeito pelo poder aos direitos individuais, traduzindo-se também em evidente significado do princípio da igualdade, na medida em que proporciona uma repartição equânime decorrente de um ônus necessário para realização do bem comum, não se poderia admitir que o legislador vulnerasse um direito previsto constitucionalmente sem a correspondente previsão de indenização, já que o dano nessas hipóteses seria certo e não eventual, especial e anormal. Haveria uma hipótese de omissão legislativa inconstitucional, ainda que essa omissão seja classificada como parcial, ou seja, refira-se apenas à ausência de previsão de prévia indenização, vulnerando tanto o princípio da igualdade, onerando mais uns que outros, e o próprio conteúdo direito fundamental.

\section{Como bem observa Enrique Sayagués Laso:}

A lei que nega a indenização sendo esta procedente, seria violadora dos
textos constitucionais que protegem os direitos individuais (...) e ademais
afetaria a competência do Poder Judicial, decidindo pela via legislativa
um conflito de direito entre as partes. (...) Por análogas razões
consideramos que também seria inconstitucional a lei que, reconhecendo
o direito à indenização fixasse limites arbitrários, inferiores aos que
deveriam corresponder. O montante deve ser justo e deve ser determinado
pelo Poder Judiciário, sem prejuízo dos acordos a que possam chegar as
partes interessadas. ${ }^{401}$ (tradução livre)

No sentido de que o agir do poder somente é adequado quando se destina a assegurar a máxima efetividade dos direitos assegurados pela Carta de Base, não se pode pretender conivência com a não preservação de direitos fundamentais, ao argumento de que ao legislador seria conferida a prerrogativa para estabelecer em quais hipóteses é cabível a indenização. Tratando-se de lei cujo conteúdo afeta o conteúdo essencial do direito, se houver uma supressão ou privação deste, ainda que predicada pela norma de maneira generalizada, a questão traduzirá um despojo de situações jurídicas

\footnotetext{
401 "La ley que negare la indemnización, siendo ésta procedente, sería violatoria de los textos constitucionales que protegen los derechos individuales (...) y además afectaría la competencia del Poder Judicial, decidiendo, por via legislativa un conflicto de derecho entre partes.(...) Por análogas razones consideramos que también seria inconstitucional la ley que, reconociendo el derecho a indemnización, fijase limites arbitrarios, inferiores a los que correspondiesen. El monto de aquélla debe ser justo y determinarlo el Poder Judicial, sin prejuicio de los acuerdos a que puedan llegar las partes interesadas". SAYAGUÉS LASO, Enrique. Tratado de derecho administrativo. T. I. Montevideo: Barreiro y Ramos S.A., 1974, pp. 609-610.
} 
individualizadas não tolerado pela norma constitucional, salvo se mediar a indenização correspondente $^{402}$.

Logo seria uma obrigação secundária, determinada pela Constituição, que o ato legislativo previsse a indenização do dano quando sua finalidade dirigir-se ao sacrifício de direito alheio e, portanto, o dano for conscientemente e intencionalmente querido.

No ordenamento jurídico brasileiro, pelas razões expostas no Capítulo 2 da Primeira Parte deste trabalho, essa indenização deveria, ainda, ser prevista na forma do regime da desapropriação, ou seja, o diploma normativo teria que dispor a respeito de uma indenização prévia, justa e em dinheiro para aqueles que foram lesados pelo ato, já que, como se ponderou, todo ato de sacrifício de direito deve submeter-se a tal regime.

Tanto a negativa em conceder a indenização, quanto o silêncio do legislador diante de uma lei lesiva, destinada especificamente à aniquilação do direito alheio, constituiriam flagrante inconstitucionalidade, sendo que ainda obrigariam o particular lesado a socorrerse de medida judicial de responsabilização do Estado para ver garantido o seu direito ao equivalente patrimonial, submetendo-se, assim, a um conjunto de medidas menos favoráveis que as consagradas pelo Constituinte originário para as hipóteses de sacrifícios de direitos, uma vez que este estaria sujeito, ao final, à regra disposta no artigo 100 da Constituição Federal.

Complementa Canotilho:

A reparação da lesão efectiva não é discricionariamente manuseável pelo legislador, embora os termos 'conforme dispuser a lei', possam favorecer a atribuição de poderes discricionários quanto à recusa, admissibilidade e medida de indemnização. O legislador regula a reparação, mas não se pode isentar a ele ou outros poderes públicos do dever de reparar sempre que, de acordo com os princípios constitucionais, se observe a existência da lesão. Caso contrário ressurgiria, de forma encapuçada, a tradicional imunidade dos entes soberanos. ${ }^{403}$

Não haveria liberdade para o legislador escolher ou não a possibilidade de concessão da indenização. A responsabilidade não é um regime de reparações colocado à discricionariedade do legislador, mas consagrado para os direitos dos cidadãos.

\footnotetext{
${ }^{402}$ Cf. ENTERRÍA, Eduardo García de. FERNÁNDEZ, Tomás-Ramón. Curso de Derecho Administrativo. v. II. 9 ed. Madri: Civitas, 2004, p. 222.

${ }^{403}$ CANOTILHO, José Joaquim Gomes de. O problema da responsabilidade do Estado por actos lícitos. Coimbra: Almedina, 1974, p. 140.
} 
Para Maria Emília Mendes Alcântara, na hipótese da lei negar expressamente o direito à indenização quando deveria concedê-la, se estaria diante de uma enunciação da responsabilidade civil do Estado decorrente de ato lícito. Isso porque, segundo o magistério da autora, nessa circunstância o dano não decorre da inconstitucionalidade, já que foi causado por dispositivo (constitucional) de um diploma legal que, por sua vez, contém outro dispositivo, este sim eivado de inconstitucionalidade, por negar a indenização. Em suas palavras: "o dano não sobreveio pela circunstância de ser a lei inconstitucional, mas apesar dessa circunstância",404.

Há que se ressaltar que a autora não faz distinção entre o dever de indenizar (correspondente patrimonial do direito) e as situações que ensejam responsabilização. Por isso caracteriza o dano ensejador da responsabilidade como decorrente do dispositivo que é constitucional.

Todavia, como já se pronunciou no início deste trabalho, o dano que gera a responsabilidade é o dano antijurídico, o resultado ilícito. Na hipótese da indenização ser prevista na lei, de forma justa e com previsão para pagamento anteriormente ao esgarçamento do direito, há um dano licitamente produzido e não se vislumbra aí nenhuma hipótese de responsabilidade estatal, nem de inconstitucionalidade da lei. De modo contrário, quanto ausente a previsão de prévia indenização ou quando esta é negada, sobrevém então a produção de um dano antijurídico - já que não houve a conversão do direito no seu equivalente patrimonial -, o que leva à aplicação da responsabilidade civil, nos termos do artigo $37, \S 6^{\circ}$, da CF. O que faz nascer a antijuridicidade apta a gerar a responsabilidade é o próprio ato, que é ilícito na medida em que desrespeitou o ordenamento constitucional, impingindo um sacrifício de direito sem a correspondente indenização, ignorando a proteção constitucional desse mesmo direito ou o princípio da igualdade que se espraia sobre todo o ordenamento.

Sendo condição para o sacrifício de direito o pagamento de prévia e justa indenização, por ordem constitucional, sob pena de vulneração da regra do artigo $5^{\circ}$, inciso XXIV, da CF, tem-se que o ato legislativo que o faz sem a prever é ilícito, devendo ser fulminado com a utilização dos remédios jurídicos disponíveis para atacá-10 ${ }^{405}$. A

${ }^{404}$ ALCÂNTARA, Maria Emília Mendes. Responsabilidade do Estado por atos legislativos e jurisdicionais. São Paulo: RT, 1988, p. 58.

${ }^{405} \mathrm{O}$ próprio legislador, quando regulamentou o regime da desapropriação em cumprimento ao comando constitucional da prévia indenização (artigo 46 da Lei Complementar n⿳o 101, de 04 de maio de 2000), já 
constitucionalidade do sacrifício estabelecido não deixa de ser auferida de acordo com o que estabelece a Constituição.

Nessa toada, há que se atentar para uma circunstância já destacada por Sayagués Laso, cuja citação foi feita acima. A lei teria que prever a indenização de forma justa, não podendo o legislador fixá-la em limites arbitrários, inferiores aos devidos. A insuficiência da indenização comportaria a inconstitucionalidade da norma que a fixa.

Se, no entanto, parece difícil querer conformar o legislador a prever uma indenização pelo sacrifício que provoca, dadas as especificidades dos casos, o que levaria, normalmente, a uma dificuldade para avaliação da extensão do dano que provoca, por outro lado pode-se ter por certo que a previsão do correspondente patrimonial do direito poderia ser feita através da consagração de critérios que viabilizassem o pagamento dos valores ao prejudicado, previamente à efetivação do esgarçamento, ou seja, antes da aplicação da lei.

Nesse ponto, torna-se relevante destacar a composição do tema elaborada por Eduardo García de Enterría que, após analisar sentenças espanholas proferidas pelo Tribunal Constitucional sobre a Lei de Águas, de 1985 e de Costas, de 1988, as quais foram objeto de recursos de inconstitucionalidade perante o referido Tribunal, em virtude da destruição que provocaram sobre o conteúdo essencial do direito de propriedade, sem dispor sobre qualquer compensação ou, quando essa era prevista, não se tratava de uma compensação suficiente, concluiu pelo balizamento de alguns critérios orientadores do assunto, os quais, embora levem em consideração as peculiaridades do ordenamento espanhol, não deixam de servir como marco para o equacionamento do tema de modo geral, especialmente em relação aos países que realizam o controle de constitucionalidade das leis, como o Brasil. Resume-se aqui suas considerações:

a. As leis de natureza expropriatória, valorando este conceito à luz da cláusula geral disposta no artigo $1^{\circ}$ da Lei de Expropriação Forçada, de 1954, cláusula constitucionalizada formalmente como expressão da garantia do artigo 33 da Constituição (direito de propriedade privada e de herança), serão inconstitucionais $\underline{\text { se não tiverem previsto em seu próprio texto a correspondente indenização; }}$

observara que é nulo de pleno direito a desapropriação efetuada sem o pagamento ou o depósito prévio da justa indenização. 
b. Quando a lei de conteúdo expropriatório tiver previsto a correspondente indenização pelo despojo por ela disposto e não haja remetido à Administração (e, sobretudo, ao subsequente controle judicial) a determinação da suficiência desta indenização, deverá haver um controle de constitucionalidade da lei de forma abstrata, ou seja, não caberá ao Tribunal Constitucional analisar todos os processos, com a valoração das milhares de situações jurídicas individuais afetadas pelo ato, para concluir ou não pela sua constitucionalidade, bastando que ele se limite a apreciar de modo abstrato o proporcional equilíbrio dos critérios indenizatórios da lei e deixe, então, a questão para ser equacionada de modo concreto;

c. A fim de evitar a privação, aos proprietários afetados, do seu direito fundamental à tutela judicial efetiva que proclama o artigo 24 da Constituição, as leis expropriatórias ad hoc ou de caso único (leis específicas), que se utilizem da força da lei para fixar indenizações de uma maneira taxativa e fechada, serão sempre inconstitucionais, por violarem o citado artigo 24;

d. A validade das leis expropriatórias que fixam critérios genéricos de indenização capazes de exceder o critério de proporcional equilíbrio, estará condicionada à possibilidade de que esses critérios possam ser ponderados, concretizados e modulados pelo juiz ordinário, em atenção às circunstâncias particulares de cada caso;

e. A eventual reclamação judicial de indenizações ponderadas e particularizadas deverá articular-se através de uma ação de responsabilidade patrimonial contra a Administração, regulada pelos artigos 139 e seguintes da Lei 30/1992 (Lei do Regime Jurídico e do Procedimento Administrativo Comum) ${ }^{406}$.

Diante disso, não há dúvidas de que o desconhecimento das circunstâncias concretas por parte do legislador ou, enfim, a impossibilidade de avaliação adequada das situações singulares, não se mostra como fator impeditivo da previsão de critérios que possam corresponder a um proporcional equilíbrio indenizatório, nas hipóteses em que o ato legislativo visa a um sacrifício de direito. Para longe disso, nem adequado seria o estabelecimento de valores de forma estanque nas leis que contivessem casos concretos, como cita o autor, desembocando na inconstitucionalidade da própria lei, na medida em

${ }^{406}$ ENTERRÍA, Eduardo García de. La responsabilidad patrimonial del Estado Legislador en el Derecho español. 2. ed. Navarra: Civitas, 2007, pp. 206-209. 
que, desse modo, tal fixação se destinaria a afastar a proteção judicial do prejudicado. A imprescindibilidade da previsão de indenização e, mais do que isso, o dever que a Constituição acomete ao legislador de prever uma indenização justa, determinam que este estabeleça na lei critérios razoáveis que permitam à Administração e, em havendo necessidade, ao Judiciário, a definição da indenização para as situações particulares.

Vale ressaltar que o descumprimento por parte do legislador de previsão de indenização para as situações de esgarçamento legítimo de um direito levará, consequentemente, ao reconhecimento da inconstitucionalidade da lei, mas também deslocará a questão para a aplicação da responsabilidade do Estado por ato legislativo inconstitucional, já que terá sido dado causa a um dano antijurídico.

Não se tratará, propriamente, como se defendeu acima, de hipótese de responsabilidade do Estado por ato legislativo constitucional, dada a mácula da omissão que envolve o próprio ato, deslocando-se para uma hipótese de responsabilidade por inconstitucionalidade do ato legislativo.

No tocante à supressão de situações baseadas na confiança legítima depositada pelo particular na atividade estatal - nos termos delineados no item anterior deste capítulo -, também se pode concluir que para sua legítima supressão ou se preveem regras de transição, quando tal for possível, minorando ou mesmo excluindo os eventuais danos causados pelo ente público ou, não havendo tal possibilidade, há que se prever a indenização através de critérios que assegurem um proporcional equilíbrio diante do prejuízo fatalmente causado.

\subsection{A prática legislativa e a ausência de previsão indenizatória}

A despeito da proteção constitucional conferida ao direito adquirido, ao ato jurídico perfeito e à coisa julgada, bem como a todos os demais direitos originários de uma situação jurídica caracterizada como direito fundamental, observa-se que a prática jurídica ultimada pelo legislador pátrio tem desconsiderado a referida proteção. Desatendem-se os requisitos acima expressados, no sentido de se elaborar lei (e também emendas constitucionais) que, embora concretizadora de um legítimo esgarçamento ou diminuição de um direito, preveja a correspondente indenização ou, no mínimo, medidas de transição que assegurem o respeito a essas situações e à boa-fé dos particulares. 
Como exemplos dessas práticas citem-se as leis editadas com vistas à preservação do meio ambiente, as quais veiculam restrições à propriedade privada no intuito de proteger as características preserváveis (ecossistema, vegetação, fauna ou flora), mas não preveem qualquer indenização por tais limitações.

Alguns desses atos protetivos, ainda que veiculados através de lei, mas posteriormente efetivados através de atos administrativos, ensejaram a propositura de demandas judiciais por parte dos particulares proprietários das referidas terras em face do Estado, pleiteando o pagamento de indenização, dado que se afetava o conteúdo do direito de propriedade de tal forma que lhe retirava o seu aproveitamento econômico.

Para ilustrar, cite-se, a Lei Paulista 5.649, de 28 de abril de 1987, que criou nos Municípios de Peruíbe, Iguape, Miracatu e Itariri a Estação Ecológica Jureia-Itatins, com vistas a assegurar a integridade dos ecossistemas e da fauna e flora nelas existentes, bem como sua utilização para fins educacionais e científicos.

Embora essa lei não mencionasse expressamente quais as restrições a que ficavam sujeitas as propriedades que integravam a estação, a definição de estação ecológica trazida pela Lei 6.902/81 implicava em grandes restrições ao uso da propriedade, uma vez que a estação ecológica deveria ter $90 \%$ (noventa por cento) ou mais de sua área destinada, em caráter permanente, à preservação integral da biota, não podendo o particular nela criar rebanhos de animais domésticos, ou, ainda, explorar os recursos naturais, exceto para fins experimentais.

Esse ato legislativo, reconhecidamente constitucional pelo Supremo Tribunal Federal por ser dever constitucional do Poder Público proteger a flora e adotar as medidas que visem a coibir práticas lesivas ao equilíbrio ambiental, proporcionou, contudo, uma condenação do Estado à reparação, dada a impossibilidade de desenvolvimento de atividade econômica pelo particular, uma vez que restou proibida a exploração do corte de madeiras na área sujeita a sua titularidade dominial.

Reconheceu-se a possibilidade de que as leis, ao imporem determinadas restrições ao direito de propriedade, podem gerar o direito à indenização, como se infere do voto do Ministro Relator Celso de Mello, no acórdão RE 134.297-8 - São Paulo:

(...) atos de desapropriação, ou de apossamento administrativo, ou, como na espécie, de imposição de restrições ditadas pela lei e por atos de índole administrativa obrigam o Estado a ressarcir os prejuízos que se 
originem da atividade pública, quando esta importar - como no caso efetivamente importou - em esvaziamento do conteúdo econômico do direito de propriedade ${ }^{407}$.

(...)

A circunstância de o Estado dispor de competência para criar reservas florestais não lhe confere, só por si - considerando-se os princípios que, em nosso sistema normativo, tutelam o direito de propriedade - a prerrogativa de subtrair-se ao pagamento de indenização patrimonial ao particular, quando a atividade pública, decorrente do exercício de atribuições em tema de direito florestal, impedir ou afetar a válida e racional exploração econômica do imóvel por seu proprietário.

Admitiu-se que o direito à preservação da integridade ambiental, por ser de índole comum, já que o ato protetivo é realizado em benefício de todos, deve ser arcado não apenas pelos proprietários de áreas localizadas na Serra do Mar, mas por toda a sociedade. Contudo, a argumentação utilizada para reconhecer o direito à indenização centralizou-se no esvaziamento do conteúdo do direito de propriedade efetuado pelo ato do Poder Público, não havendo intensa ponderação a respeito da especialidade do prejuízo ou citação expressa acerca de sua anormalidade.

Não foi enfrentado, entretanto, o problema da responsabilidade civil do Estado por atos legislativos constitucionais, posto que na prática o argumento utilizado foi o da desapropriação indireta, deixando-se de lado qualquer ponderação a respeito da inconstitucionalidade do ato normativo veiculador da restrição por não prever a correspondente indenização do prejuízo ao direito de propriedade que, evidentemente, tinha em vista provocar.

Uma questão mais recente, em que se observa a possibilidade de prejuízo decorrente de lei, ocorreu com a edição da Lei $n^{\circ} 12.684$, de 26 de julho de 2007, do Estado de São Paulo, que proibiu o uso, no referido Estado, de produtos, materiais ou artefatos que contivessem quaisquer tipos de amianto ou asbesto ou outros minerais que, acidentalmente, tivessem fibras de amianto em sua composição.

Nessa situação, a referida lei foi mais restritiva do que a lei federal existente sobre a matéria - Lei no 9.055/95 -, que também disciplina a extração, industrialização, utilização, comercialização e transporte do asbesto/amianto e dos produtos que o contenham, bem como as fibras naturais e artificiais, de qualquer origem, utilizadas para o mesmo fim.

${ }^{407}$ RE 134.297-8. Relator: Ministro Celso de Mello. Data da decisão: 13/06/1995 DJ 22/09/95. Disponível em: http://www.stf.jus.br/portal/inteiroTeor/obterInteiroTeor.asp?numero=134297\&classe=RE. Acesso em: 13.09.2009. 
A lei estadual foi objeto de Ação Direta de Inconstitucionalidade perante o Supremo Tribunal Federal (ADIN 3.937, Relator da Medida Cautelar Ministro Marco Aurélio $^{408}$ ), com pedido de liminar, sob o argumento de que, além de apresentar vícios de inconstitucionalidade formal (usurpação de competência legislativa), representava desproporcionalidade - já que os riscos à saúde que a atividade apresentava não seriam suficientes para ensejar a proibição da atividade - sendo que a lei causava, ainda, latente redução da atividade econômica no segmento, com baixa nos índices de emprego no setor produtivo.

A Corte Máxima reconheceu por sua maioria, ainda que em sede liminar, que era legítima a proibição veiculada pela lei paulista, embora não tenham sido realizados estudos específicos que comprovassem a nocividade do tipo de amianto proibido pela lei, conforme prerrogativa que é conferida pelo artigo $9^{\circ}, \S^{\circ}$ da Lei 9.868/99.

Embora se trate de lei reconhecida como constitucional, tem-se que necessariamente ela criou um prejuízo para aqueles que realizavam as atividades utilizando tais produtos no Estado de São Paulo. Ao proibir o comércio e a utilização do asbesto e do amianto, causou, indubitavelmente, um prejuízo certo, de ordem patrimonial, especial e anormal, que pode levar, inclusive, ao fechamento das empresas que operam suas atividades apenas na localidade citada.

A menos que se comprove cientificamente que, de fato, trata-se de atividade absolutamente ilícita ou irregular, há até o momento a ocorrência do sacrifício de um direito, do que se compreende a necessidade da lei prever a correspondente indenização pelos prejuízos certos que ousou causar - nem se poderia compreender de forma diferente, diante do disposto no artigo 486 da CLT, que obriga ao pagamento de indenização no caso de paralisação temporária ou definitiva do trabalho, motivada por ato de autoridade municipal, estadual ou federal, ou pela promulgação de lei ou resolução que impossibilite a continuação da atividade. Como não o fez, trata-se de lei inconstitucional, que pode ensejar a atuação da responsabilidade civil estatal em razão do citado ato legislativo.

Inúmeras outras hipóteses de leis ou emendas constitucionais que afetam direitos fundamentais dos particulares causando-lhes evidentes danos, sem prever a correspondente

408 STF. Tribunal Pleno. Julgamento em 09.06.08, DJ 10.10.08. Disponível em: http://www.stf.jus.br/portal/inteiroTeor/obterInteiroTeor.asp?numero=3937\&classe=ADI-MC. Acesso em: 21.09.09. 
indenização, poderiam ser citadas aqui. No cotidiano da prática legislativa, vê-se a elaboração de leis que afetam direitos adquiridos de aposentados, projetos destinados a parcelamentos de precatórios, planos econômicos elaborados sem a previsão de consequências e, por isso, modificados de inopino, entre outras situações.

Não é a finalidade aqui adentrar em todas essas situações, mas sim assentar a crítica de que o legislador, segundo o ordenamento pátrio, não dispõe de liberdade para, ainda que fundamentado em legítimo interesse público, amesquinhar direito alheio ou modificar ad nutum situações jurídicas que foram incitadas pelo Estado, sem prever a correspondente indenização, posto que se encontra vinculado material e formalmente aos dispositivos constitucionais. 


\section{A RESPONSABILIDADE PESSOAL DO LEGISLADOR}

\subsection{O DIREITO DE REGRESSO EM FACE DO LEGISLADOR}

Embora o tema central deste trabalho refira-se à responsabilidade do Estado, é oportuno tratar aqui, ainda que de forma breve, a respeito da responsabilidade dos agentes pelo desempenho da referida função legislativa, uma vez que, como aduz José Cretella Júnior $^{409}$, a personalização da culpa, fazendo responder o causador do dano, permite que um novo estado de coisas se implante, com grande proveito para a moral pública, ocasionando, especialmente, maior respeito aos direitos individuais e evitando-se que o Tesouro sofra prejuízos, no mais das vezes, perfeitamente evitáveis.

O parágrafo $6^{\circ}$ do artigo 37 da Carta Maior, além de estabelecer a responsabilidade objetiva do Estado, assegura o direito de regresso - que abrange não só a ação regressiva, mas também o respectivo procedimento administrativo - contra o responsável nos casos de dolo ou culpa. Assim, como já afirmado anteriormente, a responsabilidade do agente público configura-se de modo diverso da responsabilidade do Estado, pois prescinde da culpa ou dolo para sua atuação.

O direito de regresso do Estado caracteriza-se, na verdade, como uma dever, já que, face ao princípio da indisponibilidade dos interesses públicos, não pode o Estado efetuar um pagamento indevido - torna-se indevido porque houve culpa lato sensu do agente -, sem adotar as medidas cabíveis contra o causador do dano.

Embora seja pressuposto para exercício do direito de regresso a existência de um pagamento efetuado pelo Estado ao terceiro prejudicado, alguns autores admitem que o lesado poderia acionar diretamente o agente causador do dano, movendo uma ação judicial em face deste, sem necessidade de demandar indenização do Poder Público. Celso Antônio Bandeira de Mello ${ }^{410}$ pondera que, embora o lesado, ao propor a lide contra o agente, tenha de provar o dolo ou a culpa deste último, caberá ao vitimado decidir se aciona apenas o Estado, ou unicamente o agente, ou ambos conjuntamente.

\footnotetext{
${ }^{409}$ CRETELLA JÚNIOR, José. O Estado e a obrigação de indenizar. Rio de Janeiro: Forense, 1998, p. 321. ${ }^{410}$ Cf. MELlo, Celso Antônio Bandeira de. Curso de Direito Administrativo. 26. ed. São Paulo: Malheiros, 2009, p. 1024.
} 
Segundo o doutrinador, não haveria fundamento jurídico hábil que permitisse concluir acerca da impossibilidade do lesado voltar-se, ele próprio, contra o agente, já que é princípio geral, embora situado no Código Civil brasileiro: quem, por ação ou omissão voluntária, negligência ou imprudência, violar direito e causar dano a outrem, ainda que exclusivamente moral, comete ato ilícito e, por isso, fica obrigado a repará-lo (artigos 186 e 187 do Código Civil). Logo, poderia o agente responder diretamente ao lesado pelo dano que causou.

Outros autores, como José Afonso da Silva ${ }^{411}$, partem do entendimento de que o prejudicado apenas poderia promover a ação de indenização em face do Estado e não do agente, já que o prejudicado não tem que provar que o servidor procedeu com dolo ou culpa para lhe correr o direito ao ressarcimento dos danos sofridos. A impessoalidade obrigaria o prejudicado a promover a ação diretamente em face da Fazenda Pública, perante a qual ele também teria melhores meios para ver o seu direito reconhecido, sendo que poderia contar sempre com a solvabilidade desta.

Entende-se aqui, contudo, não se estaria promovendo uma forma de perseguição ao agente público (ferindo a impessoalidade) quando se permite ao lesado pleitear perante o próprio agente o direito ao ressarcimento pelo prejuízo que este lhe causou, já que, nessas situações, o autor da ação se propõe a provar o comportamento culposo ou doloso do agente, de modo que, sendo infundada a sua argumentação e desprovida de provas que a corroborem, não obterá o direito que pleiteia, sendo a ação julgada improcedente.

Outras justificativas também existem para que o terceiro prejudicado decida promover a ação diretamente contra o agente, já que nem sempre se asseguram os melhores meios de ver o seu direito ao ressarcimento reconhecido quando se propõe uma ação contra o Estado. Se, por um lado, garante-se com a ação em face da Fazenda Pública a solvabilidade do reu, por outro, submete-se o pagamento da indenização à ordem estabelecida pelo artigo 100 da Constituição Federal (pagamento por precatório), o que posterga a execução de uma eventual sentença favorável. Ademais, a existência de prazos em dobro e do duplo grau de jurisdição obrigatório também acabam retardando a prolação de uma decisão concessiva.

${ }^{411}$ Cf. SILVA, José Afonso da. Curso de Direito Constitucional Positivo. 32. ed. São Paulo: Malheiros, 2009, p. 674. 
Nesse sentido, promover uma ação em face do Estado nem sempre mostra-se a forma mais vantajosa para obter a reparação, de modo a se compreender que caberia ao lesado decidir se aciona o Estado, juntamente ou não com o agente, ou se somente a este último, conforme melhor lhe aprouver.

Contudo, no tocante aos parlamentares, é bem de se reconhecer que a responsabilidade pessoal, seja ela direta (promovida pelo próprio lesado) ou indireta (promovida pelo Estado que efetuou o pagamento da indenização), encontra grande obstáculo, tendo em vista a dificuldade fática de se comprovar a culpa ou dolo do agente na elaboração da lei, uma vez que esta, como ato complexo que é, exigindo para a sua produção a conjunção de vontades de diversos centros de competência, não permite a individualização das responsabilidades. Daí que, como conclui Maria Helena Diniz ${ }^{412}$, não há como responsabilizar os membros da Comissão de Constitucionalidade e Justiça, ou os que votaram favoravelmente à aprovação de lei inconstitucional.

Outra dificuldade em se responsabilizar pessoalmente os parlamentares decorreria das prerrogativas que são conferidas a estes para o exercício do cargo, especificamente a imunidade parlamentar, prevista nos termos do artigo 53, caput da $\mathrm{CF}$, a qual confere a inviolabilidade dos parlamentares pelas opiniões, palavras e votos proferidos. Essa prerrogativa funcional, a bem de permitir a independência necessária ao cumprimento do mandato, levaria à impossibilidade de que o legislador respondesse civilmente por ter aprovado projeto de lei, por exemplo, manifestamente inconstitucional.

Quanto ao primeiro argumento, poderia-se, ainda, contra-argumentar, com base nas lições de Nelson Schiesari ${ }^{413}$, que quando o legislador obrar com dolo ou manifesta negligência, o que somente pode ser devidamente apurado no caso concreto, não parece ser descabida a aplicação do princípio da regressividade.

No entanto, é certo que a imunidade material que lhe é conferida pela Constituição impede que responda civilmente pelos danos provocados no exercício da função legislativa, caracterizando-se, assim, a impossibilidade jurídica do Estado acionar regressivamente o legislador pelo montante pago a título de ressarcimento pelos danos causados.

\footnotetext{
${ }^{412}$ DINIZ, Maria Helena. Curso de Direito Civil brasileiro. v. 7. 24. ed. São Paulo: Saraiva, 2010, p. 660.

413 SCHIESARI, Nelson. Da responsabilidade civil do Estado e seus limites. Dissertação (Mestrado em Direto). Faculdade de Direito da Universidade de São Paulo, São Paulo, 1980, p. 159.
} 


\section{SÍNTESE CONCLUSIVA}

1. Segundo a Teoria Geral do Direito, campo em que a responsabilidade melhor se aloca, a responsabilidade não se confunde com o dever jurídico, posto que para sua atuação pressupõe-se a ocorrência de um ilícito gerador de uma sanção, enquanto que o dever jurídico corresponde a obrigação estatuída pela ordem jurídica a fim de evitar a sanção. A responsabilidade possui um caráter sancionatório, sendo que a responsabilidade civil, tendo caráter não apenas sancionatório, mas também compensatório, visa além de punir o lesante, desestimulando a prática de novos atos lesivos, também recompor o equilíbrio rompido com o ilícito, trazendo a vítima ao status quo anterior.

2. A responsabilidade civil aplicada ao Estado não destoa de tais características, mas o seu regime jurídico apresenta, hodiernamente, particularidades, se comparadas com o aplicado às pessoas privadas. Sua evolução, tomando-se por base o sistema ocidental europeu, é pautada pelo desenvolvimento de teorias que se relacionam com a concepção de Estado então vigente: aos Estados despóticos, não se atribuía a responsabilidade civil; de modo geral, na época do Estado liberal, vigiam as doutrinas civilistas, baseadas, principalmente, na ideia de culpa; a extensão do campo de atuação estatal com o surgimento do Estado Social corresponde à necessidade do alargamento da noção de culpa; frente ao Estado atual, que visa a promoção dos direitos e garantias fundamentais do cidadão, adota-se uma concepção objetiva da responsabilidade, que considera o risco da atividade estatal e a solidariedade patrimonial de todos os membros da coletividade frente ao prejuízo suportado por um determinado administrado como justificativas para a responsabilização estatal em consequência da ação danosa de um agente público.

3. Para responsabilizar o Estado com base na teoria objetiva, basta que o lesado comprove a ocorrência do dano, do nexo causal e do comportamento estatal. A desnecessidade da análise da culpa do agente desloca o respaldo da obrigação de indenizar da ilicitude dos atos para a análise do efeito que ele produz: o dano. É o dano que informa a necessidade da reparação, de modo que esta independe da ocorrência de conduta estatal lícita ou ilícita. O dano apto a desencadear a responsabilidade civil, por se tratar de uma responsabilidade jurídica, é como tal definido pela ordem jurídica, não se enquadrando neste conceito qualquer lesão econômica ou material. Somente a lesão que afronta algo que é amparado pelo sistema jurídico (dano antijurídico) faz nascer a responsabilidade civil estatal. 
4. O fundamento jurídico da responsabilidade estatal no caso de comportamentos lícitos é o princípio da igualdade e, no caso de comportamentos ilícitos, é o princípio da legalidade. De qualquer modo, é a antijuridicidade que fundamenta a responsabilidade.

5. O dano antijurídico caracteriza-se: a) pelo atingimento de uma situação jurídica legítima, suscetível de configurar um direito ou um interesse legítimo; b) por ser certo e não eventual, podendo ser atual ou futuro. No caso de comportamentos estatais lícitos, embora haja vozes dissonantes sobre a matéria, é necessário configurar-se, juntamente com tais requisitos, a especialidade e anormalidade do prejuízo, pois o fundamento justificador da responsabilização nesses casos é o princípio da repartição equânime dos ônus e encargos públicos, o qual parte do pressuposto de que ocorreu uma oneração de um indivíduo ou de um grupo de indivíduos em razão de um comportamento estatal lícito necessário à consecução do interesse público - configurando-se num prejuízo desproporcional ao inerente à vida em sociedade, e que, por isso, demanda uma compensação econômica, a qual, ao recair sobre o Estado, traduzirá a diluição do prejuízo por toda a sociedade.

6. A responsabilidade civil do Estado por ato lícito não se confunde com as hipóteses de sacrifício de direito, situação em que a ordem jurídica confere ao Estado o poder jurídico diretamente preordenado ao esgarçamento de um direito, como ocorre na desapropriação. Nessas situações de sacrifício de direito, a ordem jurídica pode constituir o Estado no dever de indenizar (obrigação subsidiária), evitando o desencadeamento de um ato ou resultado ilícito e afastando a consequente sanção. No entanto, num Estado Democrático de Direito, como o adotado pela Constituição Federal de 1988, em que se elege o respeito pelo Estado aos direitos fundamentais presentes na Carta Maior, o dever de indenizar seria uma decorrência lógica do acatamento aos direitos - posto que se trata da conversão do direito no seu equivalente patrimonial - e do princípio da igualdade, na medida em que proporciona uma repartição equânime dos ônus necessários à realização do bem comum. Daí que um sacrifício de direito sem o cumprimento do dever subsidiário levaria a uma situação de ilicitude, fazendo incidir a sanção, a responsabilidade.

7. Os sacrifícios de direito foram comumente estudados no ramo da atividade estatal conhecido como poder de polícia - expressão que recebe atualmente críticas da doutrina o qual se manifesta hoje, num sentido amplo, tanto através de atos legislativos quanto administrativos, podendo-se falar que existem atualmente leis de polícia. No exercício do referido poder, o Estado pode tanto impor condicionamentos de direito, que realizam o 
delineamento do próprio direito e, por isso, não geram direito à indenização, quanto sacrifícios de direito, que são legítimos esgarçamentos, autorizados pela ordem jurídica, e correspondem a uma diminuição, suspensão ou eliminação das possibilidades de desfrute genericamente admitidas pelo ordenamento ao direito de propriedade - que possui hoje uma ampla acepção, incluindo qualquer direito patrimonial assegurado ao cidadão - e, por isso, geram direito à indenização. Cabe salientar que somente se pode falar em sacrifício do direito de propriedade, uma vez que os demais direitos não admitem vulneração estatal, sob pena de inconstitucionalidade, a não ser nas hipóteses previstas na própria Constituição (sanção pela prática de crimes, situações de estado de defesa e estado de sítio).

8. Para caracterização de um sacrifício de direito, há que se realizar um juízo sobre a generalidade ou singularidade da medida, bem como da forma de afetação do direito, ou seja, do modo como o ato estatal afeta o conteúdo do direito, já que a este se assegura um conteúdo mínimo. Não é a transferência do direito para titularidade estatal, nem a circunstância de ser veiculado através de ato administrativo que distinguem um sacrifício de um condicionamento.

9. No ordenamento jurídico pátrio, entende-se que o sacrifício do direito exige mais do que o pagamento do seu equivalente patrimonial, mas que este seja feito previamente, ou seja, antes da efetivação do ato, e de forma justa, conforme regime disposto no artigo $5^{\circ}$, inciso XXIV, da CF. Não haveria justificativa jurídica razoável para adotar o procedimento da desapropriação tão só e unicamente para as hipóteses em que ocorre a aquisição do bem pelo expropriante, já que o dever de pagamento do equivalente patrimonial do direito está ligado a uma diminuição substanciosa das faculdades inerentes ao direito ou mesmo sua total supressão. O legislador não poderia, portanto, estabelecer um regime menos favorável quando praticasse um ato direcionado à violação do direito patrimonial, sob pena de incidir em sanção, posto que, sob a aparência do lícito, na verdade desrespeita o regime imposto pela Constituição para o aniquilamento, causando assim um dano antijurídico. Embora a matéria ainda esteja longe de ser compreendida de forma pacífica tanto pela doutrina quanto pelos tribunais pátrios, entende-se que a indenização pelo sacrifício deve abranger os danos emergentes e os lucros cessantes, os quais, todavia, devem ser efetivos.

10. A responsabilidade civil do Estado no ordenamento jurídico pátrio encontra-se, de modo geral, consagrada no artigo $37, \S 6^{\circ}$, da Constituição Federal, que reafirma o princípio da responsabilidade objetiva, acolhendo a teoria do risco administrativo. Essa imposição de 
reparar os danos causados a terceiros abrange atos estatais comissivos ou omissivos, materiais ou jurídicos, lícitos ou ilícitos, desde que imputáveis aos agentes públicos. Estes, por sua vez, respondem apenas de forma subjetiva, desde que provada a sua culpa ou dolo. É admissível a ocorrência de hipóteses excludentes de responsabilidade, as quais, por romperem o nexo causal, excluem totalmente ou ao menos atenuam a responsabilidade civil estatal. A reparabilidade abrange tanto os danos emergentes quanto os lucros cessantes. Indenizam-se também tanto os danos materiais quanto os morais.

A expressão agentes, disposta no citado dispositivo, permite a responsabilização estatal não apenas em razão do comportamento de funcionários públicos, mas qualquer um que de forma permanente, temporária ou acidental, participe da atividade do Estado. Abarca, portanto, os agentes políticos, categoria na qual se incluem os parlamentares.

11. O foco do presente trabalho é a responsabilidade civil do Estado Legislador, razão pela qual se faz necessário o estudo do desempenho da função legislativa ao longo da História, bem como das construções jurídicas que tentam explicar o conceito de lei. Compreende-se hoje que a lei não pode mais ser concebida através de um critério unicamente formal, como ato proveniente do Poder Legislativo, na medida em que o Poder Executivo também assumiu funções legislativas em determinados países, sendo que, no Brasil, formalmente, este Poder pode legislar através de medidas provisórias que, embora não sejam leis, possuem força de lei. Também não se caracteriza por um conceito material, nem se identifica como ato dotado de generalidade e abstração. Fala-se, assim, tanto na crise do conceito de lei, dada a ruptura de seus elementos característicos, como também na inadequação desta, proveniente, dentre outros fatores, da degeneração partidarista do órgão que comumente a elabora - Poder Legislativo -, para atender aos anseios de uma sociedade cada vez mais conflitiva e de interesses antinômicos.

A importância de se reconhecer que não mais subsistem os elementos caracterizadores do ato legislativo e do Estado Legislador, elaborados pela teoria constitucional dos séculos XVIII, XIX e início do XX, permite o afastamento da tese da irresponsabilidade do Estado Legislador, uma vez que de tal modo não mais se concebe que a lei é o ato sintetizador da vontade geral, que incide de forma geral e abstrata, nem se compreende que ela seja um ato de soberania, já que se submete à Constituição.

12. No Brasil, vigora o princípio da tipicidade dos atos legislativos, conforme disposto no artigo 59 da Constituição Federal. A função legislativa é exercida primordialmente pelo Poder Legislativo, embora se assegure a participação dos demais poderes no processo 
legislativo. É legítima a existência, no ordenamento jurídico brasileiro, de leis de efeitos concretos, uma vez que o modelo de Estado erigido pelo Texto Fundamental permite que este desempenhe uma atividade interventiva, estimulando, guiando e controlando a atividade dos grupos e dos indivíduos para a consecução de determinadas metas. Os atos legislativos delineados pelo artigo 59 não são os únicos que promovem inovação originária na ordem jurídica, tendo sido reconhecido já pelo Supremo Tribunal Federal que outros atos normativos também promovem essa inovação. Para fins de responsabilidade civil do Estado, outros atos normativos, que não apenas os delineados pelo artigo 59, quando possuem caráter geral e abstrato (regulamentos, por exemplo) recebem o mesmo tratamento da doutrina e da jurisprudência, com a aplicação dos mesmos princípios da responsabilidade civil do Estado Legislador, o que, entende-se, não se mostra de todo adequado, pois as especificidades de cada ato, inclusive quanto ao processo de elaboração, levarão a argumentações diversas em relação ao tema da responsabilidade civil estatal.

13. A responsabilidade civil do Estado Legislador foi a que por último surgiu na escala da evolução do instituto da responsabilidade civil estatal, sendo, ainda hoje, assunto sensível e intrincado, dada a sua natureza impactante (responsabilizar o legislador pode provocar um desequilíbrio nas finanças públicas, dado o grande número de pessoas que podem ter sido atingidas pelo ato) e a dificuldade de equilibrar a necessária liberdade legislativa com a limitação que se impõe através da responsabilização. Contudo, nos países em que há controle de constitucionalidade das leis, como no Brasil, há certa tendência da doutrina e jurisprudência admitirem a responsabilização estatal por atos legislativos inconstitucionais. Não se admite, entretanto, a responsabilização pela manifestação legislativa decorrente do Poder Constituinte Originário, uma vez que este é um Poder inicial, absoluto, ilimitado e incondicionado, e tem por função elaborar a Constituição, criando o próprio Estado.

14. A noção de lei como ato de soberania, as características de generalidade e abstração da lei, a concepção de lei como ato de criação de direitos, a representatividade dos parlamentos e a inviolabilidade dos parlamentares são os argumentos comumente utilizados para defender a tese da irresponsabilidade civil do Estado Legislador.

Todavia, tem-se o reconhecimento doutrinário de que a lei hoje não mais expressa a soberania estatal e nem esta implica irresponsabilidade. Nos tempos atuais, observa-se o caráter transitório do ato legislativo, a sua incapacidade de sintetizar e resolver os problemas de uma sociedade cada vez mais complexa e tecnológica, o seu desvio da noção 
de ato como expressão da vontade geral para expressar uma vontade política, o que leva a sua desvalorização e constante desrespeito por parte dos integrantes da sociedade, que passam a reconhecer a sua falibilidade e questioná-las perante o disposto pela Constituição.

A admissão de leis específicas (leis-medida) descaracteriza a tese que pugnava pela irresponsabilidade fundamentada na ideia de que a lei provocava a repartição dos ônus e encargos sociais. Os diferentes tipos de normas, bem como a produção de efeitos laterais ou acessórios decorrentes da lei - ainda que esta apresente características de generalidade e abstração -, que impliquem danos anormais e especiais aos direitos dos particulares, possibilitam a responsabilização estatal pelo ato legislativo.

A consagração do direito adquirido, do ato jurídico perfeito e da coisa julgada na Constituição também implicam limitação à atividade legislativa que, sob pena de inconstitucionalidade, não pode desconsiderá-los sem incidir em hipótese de desapropriação ou de responsabilidade.

A teoria do órgão, que explica a relação existente entre os agentes públicos e o Estado, permite compreender que os agentes políticos, tais como os parlamentares, uma vez investidos (eleitos, diplomados, empossados) tornam-se de pleno iure órgãos do Estado, de modo que seus atos são diretamente imputáveis ao Estado, implicando por isso responsabilização estatal. A inviolabilidade parlamentar, sendo uma proteção conferida aos parlamentos com vistas a assegurar a sua independência e liberdade, também não pode ser considerada como um privilégio apto a afastar a responsabilização estatal.

15. A doutrina costuma dividir as hipóteses de responsabilização do Estado Legislador em atos legislativos constitucionais, inconstitucionais e os casos de omissão legislativa inconstitucional. Este estudo dedica-se apenas à análise das duas primeiras situações.

16. A responsabilidade civil do Estado por atos legislativos inconstitucionais encontra maior aceitação na doutrina e jurisprudência pátria. A obrigação de indenizar por ilícito legislativo pode ser considerada como um dos efeitos da inconstitucionalidade, implicando a análise das consequências causadas in concreto pelo ato legislativo inconstitucional.

17. A Carta Maior consagra o controle judicial da constitucionalidade das leis, que pode ser feito tanto pela via de ação quanto pela via de exceção. Discute-se na doutrina pátria acerca da natureza jurídica do ato legislativo inconstitucional (ato inexistente, nulo ou anulável), uma vez que não existe disposição constitucional sobre a matéria. Tradicionalmente, o Supremo Tribunal Federal reconhece que a inconstitucionalidade 
fulmina a lei com a mácula da nulidade, de modo que todos os atos praticados durante a sua vigência deveriam ser desconstituídos. Contudo, a regra da nulidade vem sendo aplicada com temperamento pelo STF. Antes do advento da Lei $n^{\circ}$ 9.868/99, que oficializou em seu artigo 27 a possibilidade de modulação dos efeitos da inconstitucionalidade quando razões de segurança jurídica ou o excepcional interesse público o exigissem, o órgão supremo já enfrentava divergências e reconhecia a impossibilidade de desconstituir todos os atos praticados com base em lei inconstitucional. A Lei $n^{\circ}$ 9.868/99, ao permitir a declaração de inconstitucionalidade com efeitos ex nunc ou pro futuro, oficializou a prática e distanciou a nulidade da inconstitucionalidade, permitindo a proteção e a incontestabilidade de determinadas relações jurídicas, mesmo que firmadas com base em lei posteriormente reconhecida como inconstitucional.

18. No controle difuso também se observa divergência na doutrina e na jurisprudência quanto aos efeitos da declaração de inconstitucionalidade. Embora a questão ainda não se apresente pacífica, reconhece-se que a declaração de inconstitucionalidade incidenter tantum da norma pelo STF representa quebra na presunção de constitucionalidade da lei.

19. Uma lei inconstitucional equipara-se a ato ilícito e, causando danos, gera a responsabilidade civil estatal. A tão só inconstitucionalidade da lei não é suficiente para fazer atuar a responsabilidade, podendo esta apresentar inconstitucionalidades apenas formais que não geram danos (hipótese em que o legislador pode editar novo ato legislativo desprovido do vício de inconstitucionalidade formal). A lei, ainda que inconstitucional ou assim considerada apenas por um critério formal, não deixa de desencadear, ao provocar danos, a responsabilidade civil do Estado Legislador - embora a responsabilidade estatal seja una, havendo tão somente uma divisão funcional do poder. Comumente a doutrina e a jurisprudência equiparam a lei inconstitucional ao ato administrativo para fins de responsabilização, o que, entende-se, é adequado se isso facilitar a justificação da pretensão ressarcitória do lesado, mas não o é do ponto de vista da construção de uma teoria jurídica da responsabilidade estatal pelo fato das leis. Compreende-se que as formalidades a que se encontra sujeita a lei, bem como as características dos agentes integrantes do órgão que a elabora, não permitem uma completa subsunção desta ao tratamento dispensado à responsabilidade por atos administrativos. Entende-se também, embora haja divergência doutrinária, que a circunstância de intermediar um ato administrativo que dá fiel execução a uma lei inconstitucional não 
desnatura o fato de que a causa da lesão situa-se na inconstitucionalidade da lei, razão pela qual se trata de hipótese de responsabilidade civil do Estado Legislador.

20. Tradicionalmente, a doutrina pátria compreende que é necessária a declaração prévia de inconstitucionalidade da lei, por meio do controle concentrado, para que seja possível a responsabilização do Estado Legislador. Argumenta que a presunção de constitucionalidade da lei somente poderia ser elidida pelo órgão com competência específica para efetuar a referida declaração, mediante a observância do quórum e demais formalidades estabelecidas nas leis regedoras do controle concentrado. No entanto, face à postura mais flexível e menos burocrática do STF para a declaração da incompatibilidade da lei com a Carta Política, o qual reconhece que a declaração feita de forma incidental pelo plenário do referido órgão quebra a presunção de constitucionalidade da lei, e, considerando que a ordem jurídica pátria acolhe as duas modalidades de controle de constitucionalidade, permitindo a qualquer magistrado reconhecer a inconstitucionalidade de uma lei perante o caso concreto, entende-se possível o reconhecimento da inconstitucionalidade para fins de responsabilidade pela via de exceção, facultando-se ao particular a propositura de uma ação direta de indenização com requerimento incidental de declaração de inconstitucionalidade da lei, de modo a garantir maior proteção jurídica aos direitos fundamentais. Sendo possível, ainda, submeter os atos ilícitos ao regime de responsabilidade consagrado por atos lícitos, não é indispensável a prévia declaração de inconstitucionalidade da lei para que o lesado obtenha o direito à reparação, já que comprovando as características da especialidade e da anormalidade do prejuízo sofrido, poderá obter a referida reparação.

21. Nas hipóteses em que o Supremo Tribunal Federal declara a inconstitucionalidade da lei com efeitos ex nunc ou pro futuro, uma vez que essa modulação de efeitos é realizada para a proteção de bens jurídicos ou de interesses de hierarquia também constitucional, tendo-se, assim, situações jurídicas que mesmo baseadas em lei inconstitucional são válidas e eficazes, constituiria numa forma oblíqua de desmantelá-las admitir a responsabilização estatal para essas hipóteses. Na verdade, estando tais situações jurídicas de acordo com a ordem constitucional, não se afigura a existência de um dano antijurídico (que afronta o ordenamento) para permitir a responsabilização civil do Estado.

22. A responsabilidade civil do Estado por leis constitucionais é tema não tão comumente tratado e admitido pelos autores, se comparado à responsabilidade por lei inconstitucional. Todavia compreende-se que é possível que uma lei em perfeita 
consonância formal e material com a Constituição desencadeie indiretamente danos antijurídicos, ensejando o dever de reparação estatal. A afronta de determinados limites impostos ao legislador pode ser considerada necessária e não malferiria valores constitucionais, mas harmonizaria interesses coletivos e individuais. Equipara-se a responsabilidade do Estado por atos legislativos constitucionais de acordo com o regime aplicado aos atos administrativos lícitos, de modo que o dano antijurídico necessário a fazer atuar a responsabilidade é aquele que se caracteriza, para além do atingimento de uma situação jurídica legítima e de sua certeza, pelas características da especialidade e anormalidade.

Em análise as características da atividade legislativa, observa-se que predomina o reconhecimento da necessidade de liberdade para o legislador acomodar o Direito às circunstâncias cambiantes. Isso não significa, contudo, que possa fazer menoscabo dos direitos e garantias fundamentais, devendo observar os aspectos de segurança jurídica albergados pelo ordenamento, tais como o direito adquirido, o ato jurídico perfeito e a coisa julgada. O direito adquirido sintetiza a proteção das situações jurídicas consolidadas, que se incorporaram ao patrimônio moral e material do indivíduo, criando verdadeiros direitos para o seu titular. Entende-se que nem o conteúdo de um direito que se efetiva e se concretiza num titular, nem a garantia do direito adquirido podem ser suprimidos da Carta Maior por meio de emenda constitucional, sob pena de inconstitucionalidade. Apenas o Poder Constituinte originário não está adstrito à observância do direito adquirido e seus correlatos (ato jurídico perfeito e coisa julgada).

23. O princípio da proteção à confiança, aspecto subjetivo do princípio da segurança jurídica, encontra assento implícito no ordenamento jurídico pátrio, sendo corolário do Estado de Direito. A proteção à confiança abrange tanto o dever de emanar atos legislativos claros, precisos e completos, quanto revela a necessidade de proteger os cidadãos face às alterações legislativas arbitrárias e, ainda, compreende a necessidade de realização pelo Estado das promessas e compromissos que geraram esperanças fundadas nos indivíduos. Não é, contudo, qualquer confiança do particular que serve como limite à atuação legislativa, posto que conduziria à inviabilidade de sua atuação.

No direito brasileiro, há posições doutrinárias que defendem a impossibilidade de uma expectativa jurídica, que é um direito que começou a se realizar, mas ainda falta-lhe algum requisito para se completar, receber proteção jurídica perante a atividade legislativa. Compreende-se que essa conclusão admite ponderações diante das situações concretas. 
Determinados atos legislativos que pretendem o engajamento da iniciativa privada para lograr seus fins, constituindo-se em promessas firmes, destinadas a captar a adesão dos particulares, criam expectativas em relação a sua realização e a modificação dessas promessas pode resultar danosa para o particular. Na atividade estatal de planejamento, no campo da intervenção econômica ou urbana, poderia se cogitar de atitudes incitativas do Estado, geradoras de expectativas que, modificadas, ensejariam sua responsabilidade civil, pois o Estado não pode impunemente venire contra factum proprium. Há que se atentar, nessas situações, para o comportamento da vítima, pois a falta da prudência que lhe é razoável exigir pode constituir uma causa excludente ou atenuante da responsabilidade.

24. O esgarçamento de um direito adquirido ou a modificação de uma situação em que há confiança fundada do particular no comportamento estatal podem ser legitimamente realizados pelo Estado, desde que presentes razões de interesse público, auferido conforme o princípio da dignidade da pessoa humana, mostrando-se através da motivação que se trata da medida razoável e proporcional à realização do bem comum. Nesses casos, entretanto, subsiste a obrigação estatal de prever e pagar o equivalente patrimonial do direito, sob pena de flagrante desrespeito ao regime dos sacrifícios de direito estabelecido pela Carta Maior, bem como à concretização de um dano antijurídico que gera responsabilidade civil do Estado por lei inconstitucional. Entende-se que não está no campo da discricionariedade do legislador a possibilidade ou não de prever a indenização no ato legislativo destinado ao aniquilamento do direito, situando-se, no caso de ausência dessa previsão, na hipótese de omissão legislativa inconstitucional parcial. Caberá ao legislador estabelecer critérios genéricos na lei que permitam a realização concreta de um proporcional equilíbrio indenizatório previamente à concretização do ato. Em que pese tais considerações, não se vislumbra a adoção de tal prática no direito brasileiro.

25. Embora a Constituição possibilite o direito de regresso do Estado contra os agentes causadores do dano, a dificuldade de apuração de dolo ou culpa dos parlamentares na elaboração de uma lei, dada sua natureza de ato complexo - embora seja até admissível que quando o legislador obrar com dolo ou manifesta negligência apure-se a culpa que permitiria a sua responsabilização -, bem como a imunidade que lhes é conferida, não permite a concretização da responsabilização pessoal dos referidos agentes. 


\section{BIBLIOGRAFIA}

ALCÂNTARA, Maria Emília Mendes. Responsabilidade do Estado por Atos Legislativos e Jurisdicionais. São Paulo: Revista dos Tribunais, 1988.

ALMEIDA, Fernando Dias Menezes de. Responsabilidade extracontratual do Estado por atos lícitos: ensaio em homenagem a Guido Soares. In: CASELLA, Paulo Borba et al. Direito internacional, humanismo e globalidade. São Paulo: Atlas, 2008, pp. 823.

ARAÚJO, Edmir Netto de. Curso de Direito Administrativo. 4. ed. São Paulo: Saraiva, 2009.

ARLANCH, Leila Cristina Garbin. Responsabilidade patrimonial extracontratual do Estado por danos decorrentes de planejamento urbanístico e licenças urbanísticas. Revista dos Tribunais, São Paulo, v. 81, n. 677, pp. 43-58, mar.1992.

ÁVILA, Ana Paula Oliveira. A modulação de efeitos temporais pelo STF no controle de constitucionalidade: ponderação e regras de argumentação para a interpretação conforme a constituição do artigo 27 da Lei $n^{\circ}$ 9.868/99. Porto Alegre: Livraria do Advogado, 2009.

BAHIA, Saulo José Cahali. Responsabilidade civil do Estado. Rio de Janeiro: Forense, 1997.

BAPTISTA, Silvio Neves. Teoria geral do dano: de acordo com o novo Código Civil brasileiro. São Paulo: Atlas, 2003.

BARROSO, Luis Roberto. Os princípios da razoabilidade e da proporcionalidade no direito constitucional. Revista Forense. Rio de Janeiro, v. 92, n. 336, p. 125-136, out./dez. 1996.

BEZNOS, Clóvis. Aspectos jurídicos da indenização na desapropriação. Tese (Doutorado em Direito). Faculdade de Direito - Pontifícia Universidade Católica de São Paulo, São Paulo, 2002.

BIELSA, Rafael. Derecho Administrativo. T. V. 6. ed. Buenos Aires: La ley, 1966.

BINENBOJM, Gustavo. Uma teoria do Direito Administrativo. Rio de Janeiro: Renovar, 2006.

BRASIL. MINISTÉRIO DA VIAÇÃO E OBRAS PÚBLICAS. Parecer. Cláusula Ouro Responsabilidade civil do Estado por ato legislativo - Juízo arbitral. Relator: A. Gonçalves de Oliveira. Revista Forense, p. 56-57, julho, 1943.

BRUNINI, Weida Zancaner. Da responsabilidade extracontratual da administração pública. São Paulo: Revista dos Tribunais, 1981.

BUZAID, Alfredo. Da ação direta de inconstitucionalidade no direito brasileiro. São Paulo: Saraiva, 1958. 
CAHALI, Yussef Said. Responsabilidade civil do Estado. 3. ed. São Paulo: Revista dos Tribunais, 2007.

. Responsabilidade Civil: doutrina e jurisprudência. São Paulo: Saraiva, 1984.

CAMPOS, Francisco. Direito Constitucional. v. I. São Paulo - Rio de Janeiro: Freitas Bastos, 1956.

CANOTILHO, José Joaquim Gomes. O problema da responsabilidade do Estado por actos lícitos. Coimbra: Almedina, 1974.

MOREIRA, Vital. Constituição da República portuguesa anotada. v.1. 2.ed. Coimbra: Coimbra, 1984.

CARDOSO, Phelipe Vicente de Paula. Responsabilidade patrimonial do Estado por atos legislativos constitucionais. Trabalho de Conclusão de Curso (Graduação em Direito) - Faculdade de História, Direito e Serviço Social, Universidade Estadual Paulista - UNESP, 2006.

CAVALCANTI, Amaro Bezerra. Responsabilidade civil do Estado. v. 2. Rio de Janeiro: Borsói, 1957.

CAVAlCANTI, Themístocles Brandão. Curso de Direito Administrativo.V. I. 5. ed. São Paulo - Rio de Janeiro: Freitas Bastos, 1955.

CAVALIERI FILHO, Sérgio. Programa de responsabilidade civil. 8. ed. São Paulo: Atlas, 2008.

CINTRA, Antônio Carlos de Araújo. Motivo e motivação do ato administrativo. São Paulo: Revista dos Tribunais, 1979.

CLÈVE, Clèmerson Merlin. A lei no Estado contemporâneo. Cadernos de Direito Constitucional e Ciência Política. Revista dos Tribunais, São Paulo, n.21, pp. 124138, out./dez. 1997.

CRETELLA JÚNIOR, José. O Estado e a obrigação de indenizar. São Paulo: Saraiva, 1980.

. Responsabilidade civil do Estado legislador. In: CAHALI, Yussef Said (Coord.). Responsabilidade civil: doutrina e jurisprudência, São Paulo, Saraiva, pp. 169-195, 1984.

DEFINA, Cleber Pereira. A manipulação de eficácia da inconstitucionalidade como limite à responsabilidade do Estado por ato legislativo inconstitucional. Trabalho de Conclusão de Curso (Graduação em Direito) - Faculdade de História, Direito e Serviço Social, Universidade Estadual Paulista - UNESP, 2004.

DI PIETRO, Maria Sylvia Zanella. Direito Administrativo. 22. ed. São Paulo, Atlas, 2009. .(Org.). Direito Regulatório: temas polêmicos. 2. ed. Belo Horizonte: Fórum, 2004.

DIAS, José de Aguiar. Da responsabilidade civil. 11. ed. Rio de Janeiro: Renovar, 2006. 
DINIZ, Maria Helena. Curso de Direito Civil brasileiro. V.7. 24. ed. São Paulo: Saraiva, 2010.

DUGUIT, León. Las transformaciones del Derecho Público. (Traducción con estudio preliminar de Adolfo Posada y Ramon Jaen). 2. ed. Madrid: Francisco Beltran, 1926.

. Traité de Droit Constitutionnel. T. II. Paris: Ancienne Librairie Fontemoing \& Cie., 1923.

. Traité de Droit Constitutionnel. T. III. 3. ed. Paris: Ancienne Librarie Fontemoing \& Cie., 1930.

DUNA, Fabiana Cuiñas. O papel do Senado Federal no controle de constitucionalidade concreto-difuso: uma reflexão sobre a Reclamação $n^{o}$ 4.335. Monografia (Graduação em Direito) - Faculdade de Direito, Pontifícia Universidade Católica do Rio de Janeiro, Rio de Janeiro, 2007.

DROMI, Roberto. Derecho Administrativo. 4. ed. Buenos Aires: Ciudad Argentina, 1995.

ENTERRÍA, Eduardo García de. FERNÁNDEZ, Tomás-Ramón. Curso de Derecho Administrativo. v. II. 9. ed. Madrid: Civitas, 2004.

. El principio de 'la responsabilidade de los poderes públicos' según el art. 9.3 de la Constitución y la responsabilidad patrimonial del Estado legislador. Revista Española de Derecho Constitucional, Madrid, ano 23, pp. 15-47, 2003.

. La responsabilidad patrimonial del Estado Legislador en el Derecho español. Navarra: Civitas, 2007.

ESTEVES, Júlio César dos Santos. Responsabilidade civil do Estado por ato legislativo. Belo Horizonte: Del Rey, 2003.

FALLA, Fernando Garrido. Tratado de Derecho Administrativo. v. II. 4. ed. Madrid: Instituto de Estudios Políticos, 1971.

FALDINI, Cristiana Corrêa Conde. Responsabilidade do Estado pela prática de atos lícitos. Dissertação (Mestrado em Direito) - Faculdade de Direito, Universidade de São Paulo, São Paulo, 2007.

FERRARI, Regina Maria Macedo Nery. Aspectos polêmicos da responsabilidade do Estado decorrente de atos legislativos. Revista de Direito Constitucional $e$ Internacional, São Paulo, ano 10, n. 39, pp. 97-114, 2002.

FERRAZ, Sérgio. Desapropriação: indicações de doutrina e jurisprudência. Rio de Janeiro: Forense, 1972.

FERREIRA FILHO, Manoel Gonçalves. Do processo legislativo. 6. ed. São Paulo: Saraiva, 2007.

. Poder Constituinte e direito adquirido. Revista de Direito Administrativo, Rio de Janeiro, n. 210, pp. 1-9, out./dez. 1997. 
FIGUEIREDO, Lúcia Valle. O devido processo legal e a responsabilidade do Estado por dano decorrente do planejamento. Revista de Direito Administrativo, Rio de Janeiro: Renovar, v. 206, pp. 89-107, out./dez., 1996.

FRANÇA, Rubens Limongi. A irretroatividade das leis e o direito adquirido. 3. ed. São Paulo: RT, 1982.

FRANCO, João Honório de Souza. Responsabilidade extracontratual do Estado e improbidade administrativa. Dissertação (Mestrado em Direito) - Faculdade de Direito, Universidade de São Paulo, São Paulo, 2007.

FREDIANI, Yone. Responsabilidade civil do Estado legislador: mito ou realidade? Revista de Direito Constitucional e Internacional, São Paulo, v. 41, pp. 181-198, 2002.

FREITAS, Juarez (Org.). Responsabilidade do Estado. São Paulo: Malheiros, 2006.

FREITAS, Marisa Helena D'Arbo Alves de. Responsabilidade do Estado por atos legislativos. Franca: Unesp-FHDSS, 2001.

. O Estado legislador responsável. Revista de Informação Legislativa, Brasília, n. 32, pp. 285-295, 1995.

GORDILlO, Agustín. Tratado de Derecho Administrativo. Tomo 2. 5. ed. Belo Horizonte: Del Rey, 2003.

Informativo $\mathrm{n}^{\mathrm{o}} 463$ do Supremo Tribunal Federal. Brasília, 16 a 20 de abril de 2007. Disponível em: http://www.stf.jus.br/arquivo/informativo/documento/ informativo463.htm. Acesso em: 27 jun.2009

HELENE, Helio. Da responsabilidade do Estado por ato legislativo. Dissertação (Mestrado em Direito). Faculdade de Direito, Universidade de São Paulo, São Paulo, 1984.

JUSTEN FILHO, Marçal. A responsabilidade do Estado. In: FREITAS, Juarez (Org.). Responsabilidade civil do Estado, São Paulo, Malheiros, 2006, pp. 228-229.

. Conceito de interesse público e a "personalização" do direito administrativo. Revista Trimestral de Direito Público, São Paulo, n. 26, pp. 115-136, 1999.

KELSEN, Hans. Teoria pura do direito. (Trad. João Baptista Machado). 6. ed. São Paulo: Martins Fontes, 1998.

LIÑARES QUINTANA, V. Responsabilidade do Estado legislador. (Tradução de José Câmara). Revista de Direito Administrativo, Rio de Janeiro, v. 5, p. 365-376, 1946.

MARIENHOFF, Miguel S. Responsabilidad del Estado por su actividad legislativa. Revista de Direito Público, São Paulo, n. 68. pp. 5-18, out./dez. 1983.

Tratado de Derecho Administrativo. 5 v. Buenos Aires: Abeledo-Perrot, 1970.

MARTÍN, Carlos de Cabo. Sobre el concepto de ley. Madrid: Trotta, 2000. 
MARTINS-COSTA, Judith. Almiro do Couto e Silva e a re-significação do princípio da segurança jurídica na relação entre o Estado e os cidadãos. In: ÁVILA, Humberto (org.). Fundamentos do Estado de Direito: estudos em homenagem ao Professor Almiro do Couto e Silva. São Paulo: Malheiros, 2005, pp. 120-148.

MAXIMILIANO, Carlos. Direito Intertemporal ou teoria da retroatividade das leis. Rio de Janeiro: Freitas Bastos, 1946.

MEDAUAR, Odete. Segurança jurídica e confiança legítima. In: ÁVILA, Humberto (org.). Fundamentos do Estado de Direito: estudos em homenagem ao Professor Almiro do Couto e Silva. São Paulo: Malheiros, 2005, pp. 114-119.

MEDEIROS, Rui. Ensaio sobre a responsabilidade civil do Estado por actos legislativos. Coimbra: Almedina, 1992.

MENEGAlE, J. Guimarães. Direito Administrativo e Ciência da Administração. 3. ed., Rio de Janeiro: Borsoi, 1957.

MEIRELLES, Hely Lopes. Direito Administrativo brasileiro. 35. ed. (atualizada por Eurico de Andrade Azevedo, Délcio Balestero Aleixo e José Emmanuel Burle Filho). São Paulo: Malheiros, 2009.

MELlO, Celso Antônio Bandeira de. Conteúdo jurídico do princípio da igualdade. 3. ed. 10. tiragem. São Paulo: Malheiros, 2002.

. Curso de Direito Administrativo. 26. ed. São Paulo: Malheiros, 2009.

. Natureza jurídica do zoneamento - Efeitos. Revista de Direito Público. Revista dos Tribunais, São Paulo, v. 61, pp. 34-47, 1982.

MENEZES, Aderson de. Teoria geral do Estado. Rio de Janeiro, Forense, 1999.

MODESTO, Paulo. Responsabilidade do Estado pela demora na prestação jurisdicional in Revista Eletrônica sobre a Reforma do Estado. (RERE), Salvador, Instituto Brasileiro de Direito Público, $\mathrm{n}^{\circ}$ 13, mar/abr/mai, 2008. Disponível em: <http://www.direitodoestado.com.br/rere.asp>. Acesso em 27/11/2007.

MODESTO, Paulo. Reforma administrativa e direito adquirido. Revista de Direito Administrativo. Rio de Janeiro, Renovar, n. 211., pp. 79-94, jan./mar. 1998.

MONTE ALEGRE, José Sérgio. A responsabilidade patrimonial do Estado na atual jurisprudência do Supremo Tribunal Federal. Boletim de Direito Administrativo, São Paulo, NDJ, pp. 491-496, 2004.

MORAES, Guilherme Peña de. Direito Constitucional: Teoria da Constituição. 4. ed. Rio de Janeiro: Lúmen Júris, 2007.

MOREIRA, Egon Bockmann. Processo administrativo: princípios constitucionais e a Lei 9.784/1999. 3 ed. São Paulo: Malheiros, 2007.

MOTA, Maurício Jorge Pereira da. Responsabilidade civil do Estado legislador. Rio de Janeiro: Lumen Juris, 1999. 
NAGEL, José. Insuscetibilidade de apreciação judicial do ato político-legislativo. Revista de Informação Legislativa, Brasília, n. 115, p. 581-592, 1992.

OLIVEIRA, Josivaldo Félix de. A responsabilidade do Estado por ato lícito. São Paulo: Habeas Editora, 1998.

PINTO, Fernando. A presença do costume e sua força normativa. Rio de Janeiro: Líber Júris, 1982.

PIRES, Luis Manuel Fonseca. A propriedade privada em área de proteção ambiental. In: PIRES, Luis Manuel Fonseca e ZOCKUN, Maurício. (Coord.). Intervenções do Estado. São Paulo: Quartier Latin, 2008, pp. 32-53.

PIRES, Maria Coeli Simões. Direito adquirido e ordem pública: segurança jurídica e transformação democrática. Belo Horizonte: Del Rey, 2005.

PRESGRAVE, Ana Beatriz Ferrreira Rebello. Direito intertemporal e o processo civil. Dissertação (Mestrado em Direito) - Faculdade de Direito - Pontifícia Universidade Católica de São Paulo, 2005.

Prestadoras de serviço público tem responsabilidade objetiva em relação a terceiros nãousuários. Notícias do STF de 26 de agosto de 2009. Disponível em http://www.stf.jus.br/portal/cms/verNoticiaDetalhe.asp?idConteudo=112429. Acesso em 18 set. 2009.

PUCCINELLI JÚNIOR, André. A omissão legislativa inconstitucional $e \quad a$ responsabilidade do estado legislador. São Paulo: Saraiva, 2007.

RIBEIRO, Martha Chantal da Cunha Machado. Da responsabilidade do Estado pela violação do direito comunitário. Coimbra: Almedina,1996.

- O regime de responsabilidade civil extracontratual dos Estados-membros pela violação do direito comunitário: delineamento e aperfeiçoamento progressivo. Disponível em: www.almedina.net. Acesso em: 12.11.2009.

RIVERO, Jean. Direito Administrativo. (trad. de Rogério Ehrhardt Soares). Coimbra: Almedina, 1981.

ROCHA, Carmen Lúcia Antunes. Observações sobre a responsabilidade patrimonial do Estado. Revista Forense, Rio de Janeiro, n.86, v.311, pp. 3-25, 1990.

SALLES, José Carlos de Moraes. A desapropriação à luz da doutrina e da jurisprudência. 6. ed. São Paulo: RT, 2009.

SANTOLIM, César Viterbo Matos. A responsabilidade civil do Estado por ato legislativo. Estudos Jurídicos, São Leopoldo (RS), n. 55, v. 22, pp. 44-54, 1989.

SANTOS, Eliana Bueno de Miranda. Responsabilidade Civil do Estado por Atos Legislativos. São Paulo: SRS Editora, 2008.

SARMIENTO-ERAZO, Juan Pablo. La vulneración a la confianza legítima. ¿Uma situación jurídica generadora de responsabilidade del Estado legislador? 
Disponível em: http://www.javeriana.edu.co/juridicas/pub_rev/documents /4Sarmiento.pdf. Acesso em 17.10.09.

SAYAGUÉS LASO, Enrique. Tratado de Derecho Administrativo. T. I. Montevideo: Barreiro y Ramos S.A., 1974.

SCAFF, Fernando Facury. Responsabilidade civil do Estado intervencionista. 2. ed. Rio de Janeiro: Renovar, 2001.

SERRANO, Pedro Estevam A. P. O desvio de poder na função legislativa. São Paulo: FTD, 1997.

SILVA, Almiro do Couto e. A responsabilidade extracontratual do estado no direito brasileiro. Revista de Direito Administrativo, Rio de Janeiro, n. 202, pp. 19-41, out./dez. 1995.

- Responsabilidade do Estado e problemas jurídicos resultantes do planejamento. Revista de Direito Público, São Paulo, n. 63, pp. 28-36, 1982.

- O princípio da segurança jurídica (proteção à confiança) no direito público brasileiro e o direito da Administração pública anular seus próprios atos administrativos: o prazo decadencial do art. 54 da Lei do Processo Administrativo da União (Lei $\mathrm{n}^{\circ}$ 9.784/99). Revista de Direito Administrativo, Rio de Janeiro, $\mathrm{n}$. 237, pp. 271-315, jul./set. 2004.

SILVA, De Plácido e. Vocabulário Jurídico. 18. ed. Rio de Janeiro: Forense, 2001.

SILVA, José Afonso. Curso de direito constitucional positivo. 32. ed. São Paulo: Malheiros, 2009.

. Reforma constitucional e direito adquirido. Revista de Direito Administrativo, Rio de Janeiro, n. 213, p. 121-131, jul./ set. 1998.

SILVA, Juary C. A responsabilidade do Estado por atos judiciários e legislativos: teoria da responsabilidade unitária do Poder Público. São Paulo: Saraiva, 1985.

- Responsabilidade civil do Estado por atos jurisdicionais. Revista de Direito Público, São Paulo, n. 20, p. 162-187, abr./jun., 1972.

SILVA, Luís Virgílio Afonso da. O proporcional e o razoável. Revista dos Tribunais, São Paulo, n.798, v.91. pp.23-50, abr. 2002.

STOCO, Rui. Responsabilidade civil e sua interpretação jurisprudencial: doutrina e jurisprudência. 3. ed. São Paulo: Revista dos Tribunais, 1997.

Tratado de Responsabilidade Civil. 7. ed. São Paulo: Revista dos Tribunais, 2007.

SUNDFELD, Carlos Ari. Direito Administrativo Ordenador. São Paulo: Malheiros, 2003.

TÁCITO, Caio. Temas de Direito Público: estudos e pareceres. v. 2. Rio de Janeiro: Renovar, 1997. 
TRUJILLO, Elcio. Responsabilidade do Estado por atos lícitos. São Paulo: Leud, 1996.

VALLE, Vanice Regina Lírio do. Sindicar a omissão legislativa: real desafio à harmonia entre os Poderes. Belo Horizonte: Fórum, 2007.

VIOQUE, Roberto Galán. De La teoria a la realidad de La responsabilidad del Estado legislador. Disponível em: <http://www.cepc.es/rap/Publicaciones/Revistas/ 1/2001_155_285.PDF>. Acesso em 21.11.2009.

ZOCKUN, Maurício. A matriz constitucional da responsabilidade do Estado, a responsabilidade do Estado por atos legislativos e a obrigatoriedade de prévia indenização. Tese (Doutorado em Direito). Faculdade de Direito - Pontifícia Universidade Católica de São Paulo, São Paulo, 2009. 


\section{ANEXO - JURISPRUDÊNCIA}

BRASIL Superior Tribunal de Justiça. "Desapropriação. Jazida. Areia. Cascalho. Saibro. Trata-se de desapropriação para fins de reforma agrária em que se discute o cabimento de indenização de jazida mineral que, no caso, teve o seu licenciamento renovado dois meses antes da imissão do INCRA na posse, muito embora, na ocasião, não houvesse exploração na área. A Turma, por maioria, ao prosseguir o julgamento, entendeu que, havendo legítima autorização, licença ou concessão, uma vez inviabilizada pelo Poder Público a exploração da jazida, há direito à indenização, ainda que não exercida a atividade de exploração naquele momento. Trata-se na verdade, de indenização por lucros cessantes. Precedentes citados do STF: Ag no RE 140.254-SP, DJ 6/6/1997, e RE 315.135-RS, DJ 7/6/2002; do STJ: REsp 33.832-SP, DJ 28/6/1993, e REsp 77.129-SP, DJ 2/12/1996". Recurso Especial 654.321. Segunda Turma. Relatora Ministra Eliana Calmon. Julgado em 27.10.2009. Disponível no Informativo de jurisprudência $n^{o} 413$ do STJ. Disponível em: <http://www.stj.jus.br/SCON/infojur/doc.jsp>. Acesso em 08 dez. 2009.

BRASIL. Supremo Tribunal Federal. Decisão monocrática: "O Tribunal de Alçada Civil do Estado de São Paulo deu provimento ao recurso de apelação interposto pelo Município de São José do Rio Preto e à remessa ex officio, em acórdão assim ementado, verbis: 'IMPOSTO - Predial e Territorial Urbano - Municipalidade de São José do Rio Preto Exercício de 1.993 - Progressividade - Admissibilidade - Art. 156, parágrafo $1^{\circ}$, da C.F. Confisco - Inocorrência - Progressividade tem a ver com o imóvel e não com o proprietário - Capacidade contributiva resguardada - Legalidade da cobrança - Ação anulatória improcedente - Recursos providos para esse fim.' (Fls. 261). 2. Inconformada, a autora interpõe o presente recurso extraordinário, com fundamento no artigo 102, III, alínea a, da Constituição Federal, sustentando estar a decisão recorrida em confronto com os artigos $156, \S 1^{\circ}$, e 182 , da mesma Carta. 3. Prosseguindo em suas razões, a recorrente aduz ser inexigível o pagamento do IPTU com base em alíquota progressiva, considerando-se a capacidade contributiva do contribuinte. 4. É o breve relatório. 5. Decido. 6. O Tribunal Pleno, na Sessão de 20.11.96, ao julgar o RE n 153.771-0/MG (Relator para o acórdão o Ministro MOREIRA ALVES, DJU de 05.09.97), que cuidava do IPTU progressivo exigido pelo Município de Belo Horizonte, pacificou exegese segundo a qual a progressividade do IPTU, que é imposto de natureza real em que não se pode levar em consideração a capacidade econômica do contribuinte, só é admissível, em face do disposto no artigo 182, $\S 2^{\circ}$, da Constituição Federal, para o fim extrafiscal de assegurar o cumprimento da função social da propriedade, obedecidos os requisitos previstos no $\S 4^{\circ}$ do referido artigo. Ante o exposto, com fundamento no artigo 557, $\S 1^{\circ}$, do Código de Processo Civil, alterado pela Lei $\mathrm{n}^{\circ} 9.756 / 98$, conheço do recurso extraordinário e dou-lhe provimento. Invertidos os ônus da sucumbência. Intime-se". Recurso Extraordinário no 228.844. Reclamante: Aparecida Vetorasso Atabb. Reclamado: Município de São José do Rio Preto. Relator: Ministro Maurício Corrêa. J. 20/05/1999. Brasília, 16 Junho 1999. Disponível em: http://www.stf.jus.br/portal/jurisprudencia/listarJurisprudencia.asp?s 1=((228844.NUME. OU 228844.DMS.)) NAO S.PRES.\&base=baseMonocraticas. Acesso em 19.12.2009.

BRASIL. Supremo Tribunal Federal. Decisão monocrática: "Trata-se de recurso extraordinário interposto pelo Estado de São Paulo em ação movida pelos proprietários do imóvel situado na Avenida Paulista, 1919. O imóvel foi tombado pela Secretaria de Estado da Cultura em 1992 (Resolução no 36, de 16 de novembro de 1992, DOE-SP 17 de novembro de 1992, cópia a fl. 9, vol.1, destes autos). Na ação, ajuizada em dezembro de 
1992, os autores alegaram que o tombamento acabou por esvaziar o valor econômico do bem, impedindo que o imóvel fosse destinado a projetos imobiliários de grande porte. Pleitearam indenização consistente no valor apurado do imóvel, mais juros. Foi realizada perícia, com participação de assistentes técnicos de ambas as partes (fls. 165 a 403, vols. 1 e 2). A sentença julgou procedente a ação. Concluiu que o tombamento aniquilou o valor econômico do bem. Ao mesmo tempo, registrou que "não houve o apossamento de fato da propriedade dos autores", não sendo devidos juros compensatórios (fls. 461-469, vol. 2). O acórdão manteve a conclusão da sentença de primeiro grau. Anotou que o valor econômico do endereço é fator relevante para a fixação da indenização. Concluiu que esta é devida não apenas pela limitação do direito de propriedade, mas principalmente pela impossibilidade de se dar ao bem a destinação que se considerava natural naquele endereço. Novamente, reconheceu-se a inexistência do apossamento, excluindo-se juros compensatórios (fls. 773-783, vol. 4). Os autores interpuseram recurso especial pleiteando a incidência dos referidos juros compensatórios. Este recurso não foi conhecido pela Primeira Turma do Superior Tribunal de Justiça (Resp 220.983, rel. min. José Delgado, fls. 937-949, vol. 4; certidão: fl. 1010, vol. 5). O Estado de São Paulo interpôs recursos especial e extraordinário. O Superior Tribunal de Justiça, em julgamento realizado em 15 de agosto de 2000, negou provimento ao recurso especial do Estado. A Primeira Turma entendeu que as conclusões do acórdão a respeito do tombamento estavam corretas. Sobre o outro ponto do recurso (possibilidade de desapropriação face à cláusula de inalienabilidade que grava o imóvel), o relator anotou que o valor da indenização deveria ficar depositado em conta judicial até que se resolvesse a lide sobre a extensão dos gravames (Resp 220.983, fls. 1014-1069, vol. 5). O recurso extraordinário foi denegado na origem. Subiu a esta Corte em virtude de despacho proferido pelo min. Moreira Alves no AI 365.790 (fls. 540, vol. 3 do agravo). A Procuradoria Geral da República opinou pela negativa de seguimento do presente recurso por se tratar de matéria relativa a fatos e provas e questão infraconstitucional (dois pareceres a fls. 1132-1136 e 1156-1159, vol. 5). É o relatório. O recurso faz uso da hipótese da letra a, do inciso III, do art. 102 da Constituição. O Estado aponta as seguintes violações ao texto constitucional: - art. $5^{\circ}$, XXIV: a legislação municipal impõe restrições à edificação no local. Sendo assim, mesmo que o tombamento não existisse, os autores não poderiam destinar o imóvel para qualquer tipo de uso; - art. 37, § $6^{\circ}$ : não há dano, já que o Estado não se apossou do bem. - art. 216, $\S 1^{\circ}$ : não existe peculiaridade alguma no caso que justifique a indenização do tombamento. Em contra-razões, os autores alegam que não houve o devido prequestionamento. Dizem também que se trata de matéria de fato, direcionada à rediscussão das provas nos autos. No mérito, defendem que o tombamento esgotou o conteúdo econômico do bem (fls. 881-887, vol. 4). O prequestionamento é numérico, como se pode ver da seguinte passagem do acórdão (fls. 782, vol. 4): "Quanto à previsão constitucional, da proteção à propriedade (arts. $5^{\circ}$, XXII e XXIV; $182, \S 3^{\circ} ; 216, \S 1^{\circ}$ ) mais beneficia os titulares com a perda do uso pleno, ainda que sem poder alienar e os autores não se insurgem contra o tombamento em si. Pretendem ressarcimento. $\mathrm{O}$ artigo $37, \S 6^{\circ}$, da Constituição Federal reforça a indenizabilidade." No caso presente, as instâncias ordinárias reconheceram o esvaziamento completo do direito de propriedade, avaliação que resulta da elaboração de um nexo causal entre tombamento e dano. Esse nexo depende da extensão do óbice à propriedade. $\mathrm{O}$ dano resulta do esvaziamento completo desse direito (ver decisão monocrática do min. Celso de Mello que negou provimento a agravo de instrumento do Estado de São Paulo interposto nos autos da desapropriação indireta da Casa Modernista de Gregori Warchavchik: AI 127.174, RDA 200/158). Invocando lição clássica de Hely Lopes Meirelles ("o tombamento não é confisco", ver, entre outros, RT 600/15), o acórdão reconheceu que no caso estava presente esse esvaziamento completo. Eis os elementos fáticos que foram 
levados em consideração pelo Tribunal de Justiça de São Paulo (fls. 778, vol. 4): "Todos quantos caminhem pela av. Paulista e percebam a existência de raros palacetes, entre os quais situa-se o dos autos, admira-os como resistentes aos imbatíveis interesses econômicos da nação, consubstanciados nos moderníssimos arranha-ceus, construídos sobre terrenos onde outrora erguiam-se idênticas obras de arte, que o Estado não conseguiu preservar. O imóvel, ora em questão, foi objeto do interesse do Estado para preservar a cultura e a arte a benefício da posterioridade. É evidente que outros tantos interesses imobiliários e financeiros, por certo, existiriam para a aquisição do bem ora tombado, o que renderia aos proprietários valores compensadores diante da notória valorização, por metro quadrado, de imóveis situados na conhecida av. Paulista, nesta Capital." Mais à frente (fls. 783): “A Fazenda Pública, por sua vez, não tem razão porque, como acima visto, embora o tombamento, em si não se possa confundir com desapropriação indenizável, no caso presente tem prismas diferenciados para a análise, antes se tratar de imóvel cujo uso e gozo foi inegavelmente barrado aos proprietários-autores. O laudo pericial apresentado pelo ilustre 'expert' do Juízo, por este foi bem analisado, mereceu o acolhimento conferido pela sentença, inclusive, nos parâmetros das idênticas considerações contidas na bem fundamentada decisão." Transcrevo o que se contém na sentença quanto ao esvaziamento do direito à propriedade (fls. 465, vol. 2): "No presente caso, é notório que um imóvel situado na Av. Paulista tem seu valor de mercado extremamente reduzido, praticamente aniquilado, por não poder se prestar à edificação, e a Fazenda Estadual, responsável pelo tombamento, deve indenizar os autores, pelo valor total de sua propriedade, que na prática se assemelha à desapropriação indireta, para o efeito do bem ser incorporado ao patrimônio público." Considerando que se trata de endereço localizado na Avenida Paulista, é certo que a conclusão do acórdão foi pouco criativa quanto às possibilidades de uso lucrativo do imóvel. No entanto, o conjunto probatório que aparentemente demonstrou o esvaziamento econômico da propriedade não pode ser revisto em sede de recurso extraordinário (Súmula 279). Do exposto, nego seguimento ao recurso. Publique-se". RE 361.127. Reclamante: Estado de São Paulo. Reclamado: Rubens Franco de Mello e cônjuge. Relator: Ministro Joaquim Barbosa. J. 22/09/2009. Brasília, DJe-191, 09 de outubro de 2009. Disponível em: <http://www.stf.jus.br/portal/jurisprudencia/ listarJurisprudencia.asp?s1=((361127.NUME. OU 361127.DMS. $)) \quad$ NAO S.PRES.\&base=baseMonocraticas>. Acesso em: 10 out. 2009.

BRASIL. Supremo Tribunal Federal. Ementa: "INDENIZAÇÃO RESPONSABILIDADE OBJETIVA DO PODER PÚBLICO - TEORIA DO RISCO ADMINISTRATIVO - PRESSUPOSTOS PRIMÁRIOS DE DETERMINAÇÃO DESSA RESPONSABILIDADE CIVIL - DANO CAUSADO A ALUNO POR OUTRO ALUNO IGUALMENTE MATRICULADO NA REDE PÚBLICA DE ENSINO - PERDA DO GLOBO OCULAR DIREITO - FATO OCORRIDO NO RECINTO DE ESCOLA PÚBLICA MUNICIPAL - CONFIGURAÇÃO DA RESPONSABILIDADE CIVIL OBJETIVA DO MUNICÍPIO - INDENIZAÇÃO PATRIMONIAL DEVIDA - RE NÃO CONHECIDO. RESPONSABILIDADE CIVIL OBJETIVA DO PODER PÚBLICO PRINCÍPIO CONSTITUCIONAL. A teoria do risco administrativo, consagrada em sucessivos documentos constitucionais brasileiros desde a Carta Política de 1946, confere fundamento doutrinário à responsabilidade civil objetiva do Poder Público pelos danos a que os agentes públicos houverem dado causa, por ação ou por omissão. Essa concepção teórica, que informa o princípio constitucional da responsabilidade civil objetiva do Poder Público, faz emergir, da mera ocorrência de ato lesivo causado à vítima pelo Estado, o dever de indenizá-la pelo dano pessoal e/ou patrimonial sofrido, independentemente de caracterização de culpa dos agentes estatais ou de demonstração de falta do serviço 
público. - Os elementos que compõem a estrutura e delineiam o perfil da responsabilidade civil objetiva do Poder Público compreendem (a) a alteridade do dano, (b) a causalidade material entre o eventus damni e o comportamento positivo (ação) ou negativo (omissão) do agente público, (c) a oficialidade da atividade causal e lesiva, imputável a agente do Poder Público, que tenha, nessa condição funcional, incidido em conduta comissiva ou omissiva, independentemente da licitude, ou não, do comportamento funcional (RTJ 140/636) e (d) a ausência de causa excludente da responsabilidade estatal (RTJ 55/503 RTJ 71/99 - RTJ 91/377 - RTJ 99/1155 - RTJ 1 31/417). - O princípio da responsabilidade objetiva não se reveste de caráter absoluto, eis que admite o abrandamento e, até mesmo, a exclusão da própria responsabilidade civil do Estado, nas hipóteses excepcionais configuradoras de situações liberatórias - como o caso fortuito e a força maior - ou evidenciadoras de ocorrência de culpa atribuível à própria vítima (RDA 137/233 - RTJ 55/50). Responsabilidade civil do Poder Público por danos causados a alunos no recinto de estabelecimento oficial de ensino. - O Poder Público, ao receber o estudante em qualquer dos estabelecimentos da rede oficial de ensino, assume o grave compromisso de velar pela preservação de sua integridade física, devendo empregar todos os meios necessários ao integral desempenho desse encargo jurídico, sob pena de incidir em responsabilidade civil pelos eventos lesivos ocasionados ao aluno. - A obrigação governamental de preservar a intangibilidade física dos alunos, enquanto estes se encontrarem no recinto do estabelecimento escolar, constitui encargo indissociável do dever que incumbe ao Estado de dispensar proteção efetiva a todos os estudantes que se acharem sob a guarda imediata do Poder Público nos estabelecimentos oficiais de ensino. Descumprida essa obrigação, e vulnerada a integridade corporal do aluno, emerge a responsabilidade civil do Poder Público pelos danos causados a quem, no momento do fato lesivo, se achava sob a guarda, vigilância e proteção das autoridades e dos funcionários escolares, ressalvadas as situações que descaracterizam o nexo de causalidade material entre o evento danoso e a atividade estatal imputável aos agentes público". RE n. 109.615-2/ RJ. Primeira Turma. Recorrente: Prefeitura Municipal do Rio de Janeiro. Recorrido: Nelma de Castro Dias de Oliveira. Relator: Ministro Celso de Mello. J. 28/5/96. Brasília, 02 de agosto de 1996. Disponível em: $\quad<$ http://www.stf.jus.br/portal/inteiroTeor/obterInteiroTeor.asp?numero=109615 \&classe=RE $>$. Acesso em 07 dez. 2009.

BRASIL. Supremo Tribunal Federal. Ementa: "Ação cautelar inominada. Efeito suspensivo a recurso extraordinário. 2. Decisão monocrática concessiva. Referendum da Turma. 3. Existência de plausibilidade jurídica da pretensão e ocorrência do periculum in mora. 4. Cautelar, em questão de ordem, referendada". Pet 2900 Questão de Ordem. Segunda Turma. Requerente: Roberta de Leon Valiente. Requerido: Universidade Federal do Rio Grande do Sul. Relator: Ministro Gilmar Mendes. Julgado em 27/05/2003. Brasília, 01 de agosto de 2003. Disponível em: http://www.stf.jus.br/portal/inteiroTeor/obterInteiro Teor.asp?numero=2900\&classe=Pet-QO. Acesso em: 11 nov.09.

BRASIL. Supremo Tribunal Federal. Ementa: “Ação Declaratória de Constitucionalidade, ajuizada em prol da Resolução $n^{\circ}$ 07, de 18/10/2005, do Conselho Nacional de Justiça. Medida Cautelar. Patente a legitimidade da Associação dos Magistrados do Brasil - AMB para propor ação declaratória de constitucionalidade. Primeiro, por se tratar de entidade de classe de âmbito nacional. Segundo, porque evidenciado o estreito vínculo objetivo entre as finalidades institucionais da proRelator e o conteúdo do ato normativo por ela defendido (inciso IX do art. 103 da CF, com redação dada pela EC 45/04). Ação declaratória que não merece conhecimento quanto ao art. $3^{\circ}$ da resolução, porquanto, em 06/12/05, o Conselho Nacional de Justiça editou a Resolução $n^{\circ}$ 09/05, alterando substancialmente a de $\mathrm{n}^{\circ}$ 
07/2005. A Resolução $n^{\circ}$ 07/05 do CNJ reveste-se dos atributos da generalidade (os dispositivos dela constantes veiculam normas proibitivas de ações administrativas de logo padronizadas), impessoalidade (ausência de indicação nominal ou patronímica de quem quer que seja) e abstratividade (trata-se de um modelo normativo com âmbito temporal de vigência em aberto, pois claramente vocacionado para renovar de forma contínua o liame que prende suas hipóteses de incidência aos respectivos mandamentos). A Resolução $\mathrm{n}^{\circ}$ $\underline{07 / 05}$ se dota, ainda, de caráter normativo primário, dado que arranca diretamente do $\S 4^{\circ}$ do art. 103-B da Carta-cidadã e tem como finalidade debulhar os próprios conteúdos lógicos dos princípios constitucionais de centrada regência de toda a atividade administrativa do Estado, especialmente o da impessoalidade, o da eficiência, o da igualdade e o da moralidade. O ato normativo que se faz de objeto desta ação declaratória densifica apropriadamente os quatro citados princípios do art. 37 da Constituição Federal, razão por que não há antinomia de conteúdos na comparação dos comandos que se veiculam pelos dois modelos normativos: o constitucional e o infraconstitucional. Logo, o Conselho Nacional de Justiça fez adequado uso da competência que lhe conferiu a Carta de Outubro, após a Emenda 45/04. Noutro giro, os condicionamentos impostos pela Resolução em foco não atentam contra a liberdade de nomeação e exoneração dos cargos em comissão e funções de confiança (incisos II e V do art. 37). Isto porque a interpretação dos mencionados incisos não pode se desapegar dos princípios que se veiculam pelo caput do mesmo art. 37. Donde o juízo de que as restrições constantes do ato normativo do CNJ são, no rigor dos termos, as mesmas restrições já impostas pela Constituição de 1988, dedutíveis dos republicanos princípios da impessoalidade, da eficiência, da igualdade e da moralidade. É dizer: o que já era constitucionalmente proibido permanece com essa tipificação, porém, agora, mais expletivamente positivado. Não se trata, então, de discriminar o Poder Judiciário perante os outros dois Poderes Orgânicos do Estado, sob a equivocada proposição de que o Poder Executivo e o Poder Legislativo estariam inteiramente libertos de peias jurídicas para prover seus cargos em comissão e funções de confiança, naquelas situações em que os respectivos ocupantes não hajam ingressado na atividade estatal por meio de concurso público. O modelo normativo em exame não é suscetível de ofender a pureza do princípio da separação dos Poderes e até mesmo do princípio federativo. Primeiro, pela consideração de que o CNJ não é órgão estranho ao Poder Judiciário (art. 92, CF) e não está a submeter esse Poder à autoridade de nenhum dos outros dois; segundo, porque ele, Poder Judiciário, tem uma singular compostura de âmbito nacional, perfeitamente compatibilizada com o caráter estadualizado de uma parte dele. Ademais, o art. 125 da Lei Magna defere aos Estados a competência de organizar a sua própria Justiça, mas não é menos certo que esse mesmo art. 125, caput, junge essa organização aos princípios "estabelecidos" por ela, Carta Maior, neles incluídos os constantes do art. 37, cabeça. Medida liminar deferida para, com efeito vinculante: a) emprestar interpretação conforme para incluir o termo "chefia" nos inciso II, III, IV, V do artigo $2^{\circ}$ do ato normativo em foco b) suspender, até o exame de mérito desta ADC, o julgamento dos processos que tenham por objeto questionar a constitucionalidade da Resolução n ${ }^{\circ}$ 07/2005, do Conselho Nacional de Justiça; c) obstar que juízes e Tribunais venham a proferir decisões que impeçam ou afastem a aplicabilidade da mesma Resolução $n^{\circ}$ 07/2005, do CNJ e d) suspender, com eficácia ex tunc, os efeitos daquelas decisões que, já proferidas, determinaram o afastamento da sobredita aplicação”. Medida Cautelar em Ação Declaratória de Constitucionalidade $\mathrm{n}^{\circ}$ 12. Tribunal Pleno. Requerente: Associação dos Magistrados Brasileiros - AMB. Requerido: Conselho Nacional de Justiça. Relator: Ministro Carlos Britto. J. 16/02/06. Brasília, 01 de setembro de 2006. Disponível em: http://www.stf.jus.br/portal/inteiroTeor/obterInteiroTeor.asp?numero=12\&classe=ADCMC. Acesso em: 17 dez. 2009 
BRASIL. Supremo Tribunal Federal. Ementa: "AÇÃO DIRETA DE INCONSTITUCIONALIDADE - CONTROLE NORMATIVO ABSTRATO NATUREZA DO ATO INCONSTITUCIONAL - DECLARAÇÃO DE INCONSTITUCIONALIDADE - EFICÁCIA RETROATIVA - O SUPREMO TRIBUNAL FEDERAL COMO "LEGISLADOR NEGATIVO" - REVOGAÇÃO SUPERVENIENTE DO ATO NORMATIVO IMPUGNADO - PRERROGATIVA INSTITUCIONAL DO PODER PÚBLICO - AUSÊNCIA DE EFEITOS RESIDUAIS CONCRETOS - PREJUDICIALIDADE. - O repúdio ao ato inconstitucional decorre, em essência, do princípio que, fundado na necessidade de preservar a unidade da ordem jurídica nacional, consagra a supremacia da Constituição. Esse postulado fundamental de nosso ordenamento normativo impõe que preceitos revestidos de "menor" grau de positividade jurídica guardem, "necessariamente", relação de conformidade vertical com as regras inscritas na Carta Política, sob pena de ineficácia e de conseqüente inaplicabilidade. Atos inconstitucionais são, por isso mesmo, nulos e destituídos, em conseqüência, de qualquer carga de eficácia jurídica. - a declaração de inconstitucionalidade de uma lei alcança, inclusive, os atos pretéritos com base nela praticados, eis que o reconhecimento desse supremo vício jurídico, que inquina de total nulidade os atos emanados do poder público, desampara as situações constituídas sob sua égide e inibe - ante a sua inaptidão para produzir efeitos jurídicos válidos - a possibilidade de invocação de qualquer direito. a declaração de inconstitucionalidade em tese encerra um juízo de exclusão, que, fundado numa competência de rejeição deferida ao Supremo Tribunal Federal, consiste em remover do ordenamento positivo a manifestação estatal inválida e desconforme ao modelo plasmado na Carta Política, com todas as consequencias dai decorrentes, inclusive a plena restauração de eficácia das leis e das normas afetadas pelo ato declarado inconstitucional. Esse poder excepcional - que extrai a sua autoridade da própria Carta Política - converte o Supremo Tribunal Federal em verdadeiro legislador negativo. - a mera instauração do processo de fiscalização normativa abstrata não impede o exercício, pelo órgão estatal competente, da prerrogativa de praticar os atos que se inserem na esfera de suas atribuições institucionais: o de criar leis e o de revogá-las. O ajuizamento da ação direta de inconstitucionalidade não tem, pois, o condão de suspender a tramitação de procedimentos legislativos ou de reforma constitucional que objetivem a revogação de leis ou atos normativos cuja validade jurídica esteja sob exame da corte, em sede de controle concentrado. - a suspensão cautelar da eficácia do ato normativo impugnado em ação direta - não obstante restaure, provisoriamente, a aplicabilidade da legislação anterior por ele revogada - não inibe o Poder Publico de editar novo ato estatal, observados os parâmetros instituídos pelo sistema de direito positivo. - a revogação superveniente do ato normativo impugnado, em sede de controle concentrado de constitucionalidade, impede, desde que inexistentes quaisquer efeitos residuais concretos, o prosseguimento da própria ação direta". Questão de Ordem em Ação Direta de Inconstitucionalidade no 652 - MA. Tribunal Pleno. Requerente: Procurador Geral da República. Requerido: Governador do Estado do Maranhão e Assembléia Legislativa do Estado do Maranhão. Relator: Ministro Celso de Mello. J. 02/04/1992. Brasília, 02 de abril de 1993. Disponível em: http://www.stf.jus.br/portal/inteiroTeor/obterInteiroTeor.asp?numero=652\&classe=ADI.

Acesso em 19 dez.2009.

BRASIL. Supremo Tribunal Federal. Ementa: “Ação direta de inconstitucionalidade decreto legislativo estadual que sustou concorrência instaurada pelo Poder Público - ato materialmente administrativo - inviabilidade de seu exame em sede de controle normativo abstrato - não-conhecimento da ação direta quanto ao artigo 1. Do Decreto legislativo n. 
2.841/92 - ato impugnado que também define crime de responsabilidade - plausibilidade jurídica reconhecida - juízo positivo de conveniência - suspensão de eficácia do art. 2. Do decreto legislativo n. 2.841/92 do estado de mato grosso - pedido parcialmente conhecido. - Decreto legislativo que susta a realização de licitação pública convocada pelo Estado não se impregna de essência normativa. Ainda que incorporado a texto de espécie jurídica formalmente legislativa, esse ato - precisamente porque seu conteúdo veicula determinação materialmente administrativa - não se expõe a jurisdição constitucional de controle "in abstracto" do Supremo Tribunal Federal. - Decreto legislativo, ainda que emanado da União Federal, não se qualifica como instrumento juridicamente idôneo a tipificação de crimes de responsabilidade. $\mathrm{O}$ tratamento normativo dos crimes de responsabilidade ou infrações político-administrativas exige, impõe e reclama, para efeito de sua definição típica, a edição de lei especial. Trata-se de matéria que se submete, sem quaisquer exceções, ao princípio constitucional da reserva absoluta de lei formal. - A suspensão cautelar da eficácia de preceito normativo pode ter por fundamento razoes de conveniência ditadas pela necessidade de preservar a incolumidade da ordem política local e de manter, no plano jurídico-institucional, a harmonia e a independência entre os Poderes Executivo e Legislativo do Estado-membro". ADIN 834 Medida Cautelar. Tribunal Pleno. Requerente: Governador do Estado do Mato Grosso. Requerido: Presidente da Assembléia Legislativa do Estado do Mato Grosso. Relator: Ministro Celso de Mello. J. 11/02/1993. Brasília, 02 de abril de 1993.2 Disponível em: http://www.stf.jus.br/portal/inteiroTeor/obterInteiroTeor.asp?numero=834\&classe=ADIMC. Acesso em: 19 dez. 2009.

BRASIL. Supremo Tribunal Federal. Ementa: "I. Ação direta de inconstitucionalidade: seu cabimento - sedimentado na jurisprudência do Tribunal - para questionar a compatibilidade de emenda constitucional com os limites formais ou materiais impostos pela Constituição ao poder constituinte derivado: precedentes. II. Previdência social (CF, art. 40, § 13, cf. EC 20/98): submissão dos ocupantes exclusivamente de cargos em comissão, assim como os de outro cargo temporário ou de emprego público ao regime geral da previdência social: argüição de inconstitucionalidade do preceito por tendente a abolir a "forma federativa do Estado" (CF, art. 60, § 4', I): improcedência. 1. A "forma federativa de Estado" - elevado a princípio intangível por todas as Constituições da República - não pode ser conceituada a partir de um modelo ideal e apriorístico de Federação, mas, sim, daquele que o constituinte originário concretamente adotou e, como o adotou, erigiu em limite material imposto às futuras emendas à Constituição; de resto as limitações materiais ao poder constituinte de reforma, que o art. $60, \S 4^{\circ}$, da Lei Fundamental enumera, não significam a intangibilidade literal da respectiva disciplina na Constituição originária, mas apenas a proteção do núcleo essencial dos princípios e institutos cuja preservação nelas se protege. 2. À vista do modelo ainda acentuadamente centralizado do federalismo adotado pela versão originária da Constituição de 1988, o preceito questionado da EC 20/98 nem tende a aboli-lo, nem sequer a afetá-lo. 3. Já assentou o Tribunal (MS 23047-MC, Pertence), que no novo art. 40 e seus parágrafos da Constituição (cf. EC 20/98), nela, pouco inovou "sob a perspectiva da Federação, a explicitação de que aos servidores efetivos dos Estados, do Distrito Federal e dos Municípios, "é assegurado regime de previdência de caráter contributivo, observados critérios que preservem o equilíbrio financeiro e atuarial", assim como as normas relativas às respectivas aposentadorias e pensões, objeto dos seus numerosos parágrafos: afinal, toda a disciplina constitucional originária do regime dos servidores públicos - inclusive a do seu regime previdenciário - já abrangia os três níveis da organização federativa, impondo-se à observância de todas as unidades federadas, ainda quando - com base no art. 149, parágrafo único - que a proposta não altera - organizem sistema previdenciário próprio 
para os seus servidores": análise da evolução do tema, do texto constitucional de 1988, passando pela EC 3/93, até a recente reforma previdenciária. 4. A matéria da disposição discutida é previdenciária e, por sua natureza, comporta norma geral de âmbito nacional de validade, que à União se facultava editar, sem prejuízo da legislação estadual suplementar ou plena, na falta de lei federal (CF 88, arts. 24, XII, e 40, § $2^{\circ}$ ): se já o podia ter feito a lei federal, com base nos preceitos recordados do texto constitucional originário, obviamente não afeta ou, menos ainda, tende a abolir a autonomia dos Estados-membros que assim agora tenha prescrito diretamente a norma constitucional sobrevinda. 5 . É da jurisprudência do Supremo Tribunal que o princípio da imunidade tributária recíproca $(\mathrm{CF}$, art. 150, VI, a) - ainda que se discuta a sua aplicabilidade a outros tributos, que não os impostos - não pode ser invocado na hipótese de contribuições previdenciárias. 6 . A autoaplicabilidade do novo art. 40, $\S 13$ é questão estranha à constitucionalidade do preceito e, portanto, ao âmbito próprio da ação direta".ADIN 2.024. Tribunal Pleno. Requerente: Governador do Estado de Mato Grosso do Sul. Requerido: Congresso Nacional. Relator: Ministro Sepúlveda Pertence. Julgado em 03/05/2007. Brasília, DJe-042, 22 de junho de 2007. Disponível em: <http://www.stf.jus.br/portal/inteiroTeor/obterInteiroTeor.asp? numero $=2024 \&$ classe $=$ ADI $>$. Acesso em 12 nov. 2009 .

BRASIL. Supremo Tribunal Federal. Ementa: Agravo regimental em Recurso Extraordinário. IPTU. Alíquota progressiva. Declaração de inconstitucionalidade com eficácia prospectiva [ex nunc] em sede de controle difuso. Não configuração dos requisitos previstos no artigo 27 da lei n. 9.868/99. 1. A possibilidade de atribuir-se efeitos prospectivos à declaração de inconstitucionalidade, dado o seu caráter excepcional, somente tem cabimento quando o Tribunal manifesta-se expressamente sobre o tema, observando-se a exigência de quorum qualificado previsto em lei específica. 2. Em diversas oportunidades, anteriormente ao advento da emenda constitucional n. 29/00, o Tribunal, inclusive em sua composição plenária, declarou a inconstitucionalidade de textos normativos editados por diversos municípios em que se previa a cobrança do IPTU com base em alíquotas progressivas. Em nenhuma delas, entretanto, reconheceu-se a existência das razões de segurança jurídica, boa-fé e excepcional interesse social, ora invocadas pelo agravante, para atribuir eficácia prospectiva àquelas decisões. Pelo contrário, a jurisprudência da Corte é firme em reconhecer a inconstitucionalidade retroativa dos preceitos atacados, impondo-se, conseqüentemente, a repetição dos valores pagos indevidamente. Agravo regimental a que se nega provimento. AgR RE no 392.139/RJ. Agravante: Município do Rio de Janeiro. Agravado: Casa de Saúde São Miguel S/A e outro. Relator: Ministro Eros Grau. J. 26.04.05. Brasília, 13 de maio de 2005. Disponível em: $\quad$ http://www.stf.jus.br/portal/inteiroTeor/obterInteiroTeor.asp?numero=392139 \&classe=RE-AgR. Acesso em: 20 out. 2009.

BRASIL. Supremo Tribunal Federal. Ementa: "Agravo Regimental no Recurso Extraordinário. Responsabilidade civil objetiva do Estado. Artigo 37, § 6º da Constituição. Crime praticado por policial militar durante o período de folga, usando arma da corporação. Responsabilidade civil objetiva do Estado. Precedentes. Agravo Regimental a que se nega provimento".AgR RE 418.023-5 - RJ. Agravante: Estado do Rio de Janeiro. Agravado: Magno da Silva Soares e outro. Relator: Ministro Eros Grau. Segunda Turma. J. 09/09/08. Brasília, DJe-197, 17 de outubro de 2008. Disponível em: http://www.stf.jus.br/portal/inteiroTeor/obterInteiroTeor.asp?numero=418023\&classe=REAgR. Acesso em 10 ago. 2009. 
BRASIL. Supremo Tribunal Federal. Ementa: "Agravo Regimental no Recurso Extraordinário. Responsabilidade objetiva do Estado. Agente público. CB/88, artigo 37, § $6^{\circ}$. O texto constitucional não restringiu a responsabilidade do Estado aos atos praticados por todos os agentes públicos. Precedentes. Agravo regimental a que se nega provimento." AgR no RE no 518.278-9. Segunda Turma. Agravante: Carlos Humberto de Souza. Agravado: Carlos Alberto Carvalho de Vilhena e outro. Relator: Ministro Eros Grau. J. 31/03/2009. Brasília, DJe-24-04-2009. Disponível em: <http://www.stf.jus.br/ portal/inteiroTeor/obterInteiroTeor.asp?numero=518278\&classe $=\mathrm{RE}-\mathrm{AgR}>$. Acesso em 10 ago. 2009.

BRASIL. Supremo Tribunal Federal. Recurso em Mandado de Segurança n ${ }^{\circ}$ 14.553/MG. Recorrente: Clóvis da Silva Araújo e outro. Recorrida: Prefeitura Municipal de Ipanema. Relator: Luiz Galotti. J. 13.04.65. Revista Trimestral de Jurisprudência, Brasília, v.33, n. 2, pp.328-336, ago./1965.

BRASIL. Supremo Tribunal Federal. Ementa: “Ação Direta de Inconstitucionalidade. Medida Provisória. Revogação. Pedido de liminar. Por ser a medida provisória ato normativo com força de lei, não é admissível seja retirada do Congresso Nacional a que foi remetida para o efeito de ser ou não convertida em Lei. Em nosso sistema jurídico, não se admite declaração de inconstitucionalidade de lei ou ato normativo com força de lei por lei ou por ato normativo com força de lei posteriores. O controle de constitucionalidade da lei ou dos atos normativos é da competência exclusiva do Poder Judiciário, Os Poderes Executivo e Legislativo, por sua Chefia - e isso mesmo tem sido questionado como o alargamento da legitimação ativa na ação direta de inconstitucionalidade -, podem deixar de aplicar administrativamente as leis ou atos com força de lei que considerem inconstitucionais. A Medida Provisória $\mathrm{n}^{\circ}$ 175, porém, pode ser interpretada (interpretação conforme a Constituição) como ab-rogatória das Medidas Provisórias n ${ }^{\circ}$ s. 153 e 156. Sistema de ab-rogação das Medidas Provisórias no direito brasileiro. Rejeição, em face desse sistema de ab-rogação, da preliminar de que a presente ação direta de inconstitucionalidade está prejudicada, pois as Medidas Provisórias $n^{\circ}$ s. 153 e 156, neste momento, só estão suspensas pela ab-rogação sob condição resolutiva, ab-rogação que só se tornará definitiva se a Medida Provisória $n^{\circ} 175$ vier a ser convertida em lei. E essa suspensão, portanto, não impede que as Medidas Provisórias suspensas se revigorem, no caso de não conversão da ab-rogante. O que está prejudicado, neste momento em que a abrogação está em vigor, é o pedido de concessão de liminar, certo como é que esse concessão só tem eficácia de suspender ex nunc a lei ou ato normativo impugnado. E, evidentemente, não há que se examinar, neste instante, a suspensão do que já está suspenso pela ab-rogação decorrente de outra Medida Provisória em vigor. Pedido de Liminar julgado prejudicado si et in quantum". Medida cautelar em Ação Direta de Inconstitucionalidade $n^{\circ}$ 221/DF. Tribunal Pleno. Requerente: Procurador Geral da República. Requerido: Presidente da República. Relator: Ministro Moreira Alves. J. 20.03.90. DJ 22.10.1993. Disponível em: http://redir.stf.jus.br/paginador/paginador.jsp? docTP=AC\&docID=346262\&pgI=1\&pgF=100000. Acesso em: 08.07.2009.

BRASIL. Supremo Tribunal Federal. Ementa: "ATO LEGISLATIVO INCONSTITUCIONALIDADE - RESPONSABILIDADE CIVIL DO ESTADO. Cabe responsabilidade civil pelo desempenho inconstitucional da função de legislar”. Recurso Extraordinário $\mathrm{n}^{\mathrm{o}}$ 158.962. Recorrente: Banco Central do Brasil. Recorrido: Anísio Amando Cunha Maia. Relator: Ministro Celso de Mello, J. 04.12.1992. Brasília, 18 de 
dezembro de 1992. Revista de Direito Administrativo, Rio de Janeiro, v. 191, p. 175-177, 1993.

BRASIL. Supremo Tribunal Federal. Ementa: "Competência normativa - comércio. Na dicção da ilustrada maioria, em relação à qual guardo reservas, não há relevância em pedido de concessão de liminar, formulado em ação direta de inconstitucionalidade, visando à suspensão de lei local vedadora do comércio de certo produto, em que pese à existência de legislação federal viabilizando-o". Medida Cautelar em Ação Direta de Inconstitucionalidade $n^{\circ}$ 3937-7/SP. Tribunal Pleno. Requerente: Confederação Nacional dos Trabalhadores da Indústria. Requerido: Governador do Estado de São Paulo e Assembléia Legislativa do Estado de São Paulo. Relator: Ministro Marco Aurélio. J. 04/06/2008. Brasília, DJe-192, 10 de outubro de 2008. Disponível em: $<$ http://www.stf.jus.br/portal/inteiroTeor/obterInteiroTeor.asp?numero=3937\&classe=ADI -MC>. Acesso em: 21 set.09.

BRASIL. Supremo Tribunal Federal. Ementa: "Constitucional. Administrativo Civil. Responsabilidade civil do Estado. Ato omissivo do Poder Público: detento ferido por outro detento. Responsabilidade subjetiva. Responsabilidade subjetiva. Culpa publicizada: falta do serviço. CF, ART. $37, \S 6^{\circ}$ ”. I. - Tratando-se de ato omissivo do poder público, a responsabilidade civil por esse ato é subjetiva, pelo que exige dolo ou culpa, em sentido estrito, esta numa de suas três vertentes -- a negligência, a imperícia ou a imprudência -não sendo, entretanto, necessário individualizá-la, dado que pode ser atribuída ao serviço público, de forma genérica, a falta do serviço. II. - A falta do serviço -- faute du service dos franceses -- não dispensa o requisito da causalidade, vale dizer, do nexo de causalidade entre ação omissiva atribuída ao poder público e o dano causado a terceiro. III. - Detento ferido por outro detento: responsabilidade civil do Estado: ocorrência da falta do serviço, com a culpa genérica do serviço público, por isso que o Estado deve zelar pela integridade física do preso. IV. - RE conhecido e provido”. RE 382.054. Segunda Turma. Recorrente: Jorge Luiz dos Santos. Recorrido: Estado do Rio de Janeiro. Relator: Ministro Carlos Velloso. J. 03/08/2004. Brasília, 01 de outubro de 2004. Disponível em: http://www.stf.jus.br/portal/inteiroTeor/obterInteiroTeor.asp?numero=382054\&classe=RE. Acesso em: 09 dez.2009

BRASIL. Supremo Tribunal Federal. Ementa: "Controle incidente de constitucionalidade de normas. Reserva de Plenário (Const., art. 97): inaplicabilidade, pelos outros tribunais, quando já declarada pelo Supremo Tribunal, ainda que incidentemente, a inconstitucionalidade da norma questionada: precedentes. 1. A reserva de plenário da declaração da lei ou ato normativo funda-se na presunção de constitucionalidade que os protege, somado a razões de segurança jurídica. 2. A decisão plenária do Supremo Tribunal, declaratória da inconstitucionalidade, sendo pressuposto necessário e suficiente para que o Senado lhe confira efeitos erga omnes elide a presunção de constitucionalidade: a partir daí, podem os órgãos parciais dos outros tribunais acolhê-la para fundar a decisão de casos concretos ulteriores, prescindindo de submeter a questão de constitucionalidade ao seu próprio plenário". RE 191.896-9/PR. Primeira Turma. Recorrente: União Federal. Recorrido: H Costa Engenharia e Comércio Ltda. e outros. Relator: Ministro Sepúlveda Pertence. J. 27.05.97. Brasília, 29 de agosto de 1997. Disponível em: http://redir.stf.jus.br/paginador/paginador.jsp?docTP=AC\&docID=232399\&pgI=1\&pgF=1 00000. Acesso em: 13 out.09. 
BRASIL. Supremo Tribunal Federal. Ementa: "Desapropriação - Correção monetária lucros cessantes. Não cabe o pagamento de lucros cessantes no cômputo da indenização devida ao expropriado. Interpretação da Lei $\mathrm{n}^{\circ}$ 4.686, de 21 de junho de 1965”. Recurso Extraordinário $\mathrm{n}^{\circ}$ 63.926. Primeira Turma. Departamento de Estradas de rodagem versus Ernesto Siqueira Júnior. Relator: Ministro Amaral Santos. Brasília, 28 de agosto de 1969. Revista de Direito Administrativo, Rio de Janeiro, n. 102, pp. 192 - 194.

BRASIL. Supremo Tribunal Federal. Ementa: "Desrespeito à Constituição - modalidades de comportamentos inconstitucionais do Poder Público. - O desrespeito à Constituição tanto pode ocorrer mediante ação estatal quanto mediante inércia governamental. A situação de inconstitucionalidade pode derivar de um comportamento ativo do Poder Público, que age ou edita normas em desacordo com o que dispõe a Constituição, ofendendo-lhe, assim, os preceitos e os princípios que nela se acham consignados. Essa conduta estatal, que importa em um facere (atuação positiva), gera a inconstitucionalidade por ação. - Se o Estado deixar de adotar as medidas necessárias à realização concreta dos preceitos da Constituição, em ordem a torná-los efetivos, operantes e exeqüíveis, abstendose, em consequiência, de cumprir o dever de prestação que a Constituição lhe impôs, incidirá em violação negativa do texto constitucional. Desse non facere ou non praestare, resultará a inconstitucionalidade por omissão, que pode ser total, quando é nenhuma a providência adotada, ou parcial, quando é insuficiente a medida efetivada pelo Poder Público. Salário mínimo - satisfação das necessidades vitais básicas - garantia de preservação de seu poder aquisitivo. - A cláusula constitucional inscrita no art. $7^{\circ}, \mathrm{IV}$, da Carta Política - para além da proclamação da garantia social do salário mínimo consubstancia verdadeira imposição legiferante, que, dirigida ao Poder Público, tem por finalidade vinculá-lo à efetivação de uma prestação positiva destinada (a) a satisfazer as necessidades essenciais do trabalhador e de sua família e (b) a preservar, mediante reajustes periódicos, o valor intrínseco dessa remuneração básica, conservando-lhe o poder aquisitivo. - O legislador constituinte brasileiro delineou, no preceito consubstanciado no art. $7^{\circ}$, IV, da Carta Política, um nítido programa social destinado a ser desenvolvido pelo Estado, mediante atividade legislativa vinculada. Ao dever de legislar imposto ao Poder Público - e de legislar com estrita observância dos parâmetros constitucionais de índole jurídico-social e de caráter econômico-financeiro (CF, art. $7^{\circ}$, IV) -, corresponde o direito público subjetivo do trabalhador a uma legislação que lhe assegure, efetivamente, as necessidades vitais básicas individuais e familiares e que lhe garanta a revisão periódica do valor salarial mínimo, em ordem a preservar, em caráter permanente, o poder aquisitivo desse piso remuneratório. Salário mínimo - valor insuficiente - situação de inconstitucionalidade por omissão parcial. - A insuficiência do valor correspondente ao salário mínimo, definido em importância que se revele incapaz de atender as necessidades vitais básicas do trabalhador e dos membros de sua família, configura um claro descumprimento, ainda que parcial, da Constituição da República, pois o legislador, em tal hipótese, longe de atuar como o sujeito concretizante do postulado constitucional que garante à classe trabalhadora um piso geral de remuneração $\left(\mathrm{CF}\right.$, art. $\left.7^{\circ}, \mathrm{IV}\right)$, estará realizando, de modo imperfeito, o programa social assumido pelo Estado na ordem jurídica. - A omissão do Estado - que deixa de cumprir, em maior ou em menor extensão, a imposição ditada pelo texto constitucional - qualifica-se como comportamento revestido da maior gravidade político-jurídica, eis que, mediante inércia, o Poder Público também desrespeita a Constituição, também ofende direitos que nela se fundam e também impede, por ausência de medidas concretizadoras, a própria aplicabilidade dos postulados e princípios da Lei Fundamental. - As situações configuradoras de omissão inconstitucional ainda que se cuide de omissão parcial, derivada da insuficiente concretização, pelo Poder 
Público, do conteúdo material da norma impositiva fundada na Carta Política, de que é destinatário - refletem comportamento estatal que deve ser repelido, pois a inércia do Estado qualifica-se, perigosamente, como um dos processos informais de mudança da Constituição, expondo-se, por isso mesmo, à censura do Poder Judiciário. Inconstitucionalidade por omissão - descabimento de medida cautelar. - A jurisprudência do Supremo Tribunal Federal firmou-se no sentido de proclamar incabível a medida liminar nos casos de ação direta de inconstitucionalidade por omissão (RTJ 133/569, Rel. Min. Marco Aurélio; ADIn 267-DF, Rel. Min. Celso de Mello), eis que não se pode pretender que mero provimento cautelar antecipe efeitos positivos inalcançáveis pela própria decisão final emanada do STF. - A procedência da ação direta de inconstitucionalidade por omissão, importando em reconhecimento judicial do estado de inércia do Poder Público, confere ao Supremo Tribunal Federal, unicamente, o poder de cientificar o legislador inadimplente, para que este adote as medidas necessárias à concretização do texto constitucional. - Não assiste ao Supremo Tribunal Federal, contudo, em face dos próprios limites fixados pela Carta Política em tema de inconstitucionalidade por omissão $\left(\mathrm{CF}\right.$, art. $\left.103, \S 2^{\circ}\right)$, a prerrogativa de expedir provimentos normativos com o objetivo de suprir a inatividade do órgão legislativo inadimplente". Medida Cautelar em Ação Direta de Inconstitucionalidade n. 1.458. Tribunal Pleno. Requerente: Confederação Nacional dos Trabalhadores na Saúde - CNTS. Requerido: Presidente da República e Congresso Nacional. Relator: Ministro Celso de Mello. J. em 23/05/1996. Brasília, 20 de setembro de 1996. Disponível em: <http://www.stf.jus.br/portal/inteiroTeor/obterInteiro Teor.asp?numero=1458\&classe=ADI-MC $>$. Acesso em: 28 fev.09.

BRASIL. Supremo Tribunal Federal. Ementa: "Direito Constitucional e Tributário. Ação Direta de Inconstitucionalidade de Emenda Constitucional e de Lei Complementar. I.P.M.F. Imposto Provisório sobre a Movimentação ou a Transmissão de Valores e de Créditos e Direitos de Natureza Financeira - I.P.M.F. Artigos 5., par. 2., 60, par. 4., incisos I e IV, 150, incisos III, "b", e VI, "a", "b", "c" e "d", da Constituição Federal. 1. Uma Emenda Constitucional, emanada, portanto, de Constituinte derivada, incidindo em violação a Constituição originaria, pode ser declarada inconstitucional, pelo Supremo Tribunal Federal, cuja função precípua é de guarda da Constituição (art. 102, I, "a", da C.F.). 2. A Emenda Constitucional n. 3, de 17.03.1993, que, no art. 2., autorizou a União a instituir o I.P.M.F., incidiu em vício de inconstitucionalidade, ao dispor, no parágrafo 2. desse dispositivo, que, quanto a tal tributo, não se aplica "o art. 150, III, "b" e VI", da Constituição, porque, desse modo, violou os seguintes princípios e normas imutáveis (somente eles, não outros): 1. - O princípio da anterioridade, que é garantia individual do contribuinte (art. 5., par. 2., art. 60, par. 4., inciso IV e art. 150, III, "b" da Constituição); 2. - O princípio da imunidade tributaria recíproca (que veda a União, aos Estados, ao Distrito Federal e aos Municípios a instituição de impostos sobre o patrimônio, rendas ou serviços uns dos outros) e que e garantia da Federação (art. 60, par. 4., inciso I,e art. 150, VI, "a", da C.F.); 3. - A norma que, estabelecendo outras imunidades impede a criação de impostos (art. 150, III) sobre: "b"): templos de qualquer culto; "c"): patrimônio, renda ou serviços dos partidos políticos, inclusive suas fundações, das entidades sindicais dos trabalhadores, das instituições de educação e de assistência social, sem fins lucrativos, atendidos os requisitos da lei; e "d"): livros, jornais, periódicos e o papel destinado a sua impressão; 3. Em consequencia, é inconstitucional, também, a Lei Complementar n. 77, de 13.07.1993, sem redução de textos, nos pontos em que determinou a incidência do tributo no mesmo ano (art. 28) e deixou de reconhecer as imunidades previstas no art. 150, VI, "a", "b", "c" e "d" da C.F. (arts. 3., 4. e 8. do mesmo diploma, L.C. n. 77/93). 4. Ação Direta de Inconstitucionalidade julgada procedente, em parte, para tais fins, por maioria, nos termos 
do voto do Relator, mantida, com relação a todos os contribuintes, em caráter definitivo, a medida cautelar, que suspendera a cobrança do tributo no ano de 1993". ADIN 939-7/DF. Tribunal Pleno. Requerente: Confederação Nacional dos Trabalhadores no Comércio. Requerido: Presidente da República e Congresso Nacional. Relator: Ministro Sydney Sanches. J. em 15/12/1993. Brasília, 18 de março de 1994. Disponível em: $\quad\langle$ http://www.stf.jus.br/portal/inteiroTeor/obterInteiroTeor.asp?id=266590 \&idDocumento $=\&$ codigoClasse $=504 \&$ numero $=939 \&$ siglaRecurso $=\&$ classe $=$ ADI $>$.

Acesso em: 12 nov. 2009.

BRASIL. Supremo Tribunal Federal. Ementa: "Inconstitucionalidade - incidente deslocamento do processo para o órgão especial ou para o pleno - Desnecessidade. Versando a controvérsia sobre ato normativo já declarado inconstitucional pelo guardião maior da Carta Política da República - o Supremo Tribunal Federal - descabe o deslocamento previsto no artigo 97 do referido Diploma maior. O julgamento de plano pelo órgão fracionado homenageia não só a racionalidade, como também implica interpretação teleológica do artigo 97 em comento, evitando a burocratização dos atos judiciais no que nefasta ao princípio da economia e da celeridade. A razão de ser do preceito esta na necessidade de evitar-se que órgãos fracionados apreciem, pela vez primeira, a pecha de inconstitucionalidade argüida em relação a um certo ato normativo". Agravo Regimental em Agravo de Instrumento $n^{\circ}$ 168.149. Segunda Turma. Agravante: União Federal. Agravado: Farmácia Verdebranco Ltda. Relator: Ministro Marco Aurélio. Julgado em 26/06/1995. Brasília, 04 de agosto de 1995. Disponível em: http://www.stf.jus.br/portal/inteiroTeor/obterInteiroTeor.asp?numero=168149\&classe=AIAgR. Acesso em: 16 set. 2009.

BRASIL. Supremo Tribunal Federal. Ementa: "Inconstitucionalidade por omissão relativa: alegação contra a med. prov. 296/91: plausibilidade: denegação, porém, da liminar. 1. Ação direta contra a med. prov. 296/91 que - diversamente de outra, proposta contra o mesmo ato normativo (ADIN 525) -, não postula a invalidade dos benefícios concedidos aos servidores federais nela contemplados, mas se funda, ao contrario, na alegada omissão do Presidente da Republica, na medida em que não os estendeu a totalidade do pessoal civil da União, como imposta pelas normas constitucionais (CF, arts. 37, X, e 39, par. 1.): plausibilidade jurídica da alegação de mérito. 2. Considerações sobre o dilema - na hipótese de ofensa a isonomia pela norma legal que, concedendo vantagens a uns, não as estende a outros, em situação idêntica -, entre a declaração da inconstitucionalidade positiva da lei discriminatória ou da inconstitucionalidade da omissão relativa. 3. Inadmissibilidade, em princípio, da antecipação cautelar provisória da declaração de inconstitucionalidade por omissão (ADIn 361, 5.10.90), agravada, na espécie, em que o ato normativo que traduziria a discriminação alegada e uma medida provisória, ainda pendente de apreciação pelo Congresso Nacional e, portanto, ela mesma, com vigência provisória e resolúvel. ADIN 529-MC. Tribunal Pleno. Requerente: Partido dos Trabalhadores. Requerido: Presidente da República. Relator: Ministro Sepúlveda Pertence. J. 19.06.1991. Brasília, 05 de março de 1993. Disponível em: http://www.stf.jus.br/ portal/inteiroTeor/obterInteiroTeor.asp?numero=529\&classe=ADI-MC.. Acesso em 28 fev. 2009.

BRASIL. Supremo Tribunal Federal. Ementa: "MAGISTRADO. INCIDÊNCIA IMEDIATA DA PROIBIÇÃO CONTIDA NO ARTIGO 114, I, DA CONSTITUIÇÃO FEDERAL NA REDAÇÃO DADA PELA EMENDA CONSTITUCIONAL N. 7/77. NÃO HÁ DIREITO ADQUIRIDO CONTRA TEXTO CONSTITUCIONAL, RESULTE 
ELE DO PODER CONSTITUINTE ORIGINARIO, OU DO PODER CONSTITUINTE DERIVADO. PRECEDENTES DO S.T.F. RECURSO EXTRAORDINÁRIO CONHECIDO E PROVIDO". Recurso Extraordinário $\mathrm{n}^{\circ}$ 94.414. Tribunal Pleno. Recorrente: Estado de São Paulo. Recorrido: Adalberto José de Queiroz Telles de Camargo Aranha e outro. Relator: Ministro Moreira Alves. J. 13.02.1985. Brasília, 19 de abril de 1985. Disponível em: http://www.stf.jus.br/portal/inteiroTeor/obterInteiroTeor.asp? numero=94414\&classe=RE. Acesso em: 18 nov.2009.

BRASIL. Supremo Tribunal Federal. Ementa: "Magistrado. Garantia constitucional da irredutibilidade de vencimento. a nova qualificação do tempo de serviço, anos depois de averbado e de haver produzido efeitos pecuniários em favor do magistrado, malfere a garantia constitucional da irredutibilidade de vencimentos, que torna intangível o direito que ja nasceu e não pode ser suprimido sem que sejam diminuídas as prerrogativas que suportam o seu cargo. recurso conhecido e provido". Recurso Extraordinário no 105.789. Segunda Turma. Recorrente: Simonidis Loddi. Recorrido: Presidente do Tribunal de Justiça do Estado de Minas Gerais. Relator: Ministro Carlos Madeira. J. 15/04/1986. Brasília, 09 de maio de 1986. Disponível em: http://www.stf.jus.br/portal/inteiroTeo r/obterInteiroTeor.asp?numero=105789\&classe=RE. Acesso em: 19 dez. 2009.

BRASIL. Supremo Tribunal Federal. Ementa: "1.Mandado de Segurança. 2. Acórdão do Tribunal de Contas da União. Prestação de Contas da Empresa Brasileira de Infra-estrutura Aeroportuária - INFRAERO. Emprego Público. Regularização de admissões. 3. Contratações realizadas em conformidade com a legislação vigente à época. Admissões realizadas por processo seletivo sem concurso público, validadas por decisão administrativa e acórdão anterior do TCU. 4. Transcurso de mais de dez anos desde a concessão da liminar no mandado de segurança. 5. Obrigatoriedade da observância do princípio da segurança jurídica enquanto subprincípio do Estado de Direito. Necessidade de estabilidade das situações criadas administrativamente. 6. Princípio da confiança como elemento do princípio da segurança jurídica. Presença de um comRelator de ética jurídica e sua aplicação nas relações jurídicas de direito público. 7. Concurso de circunstâncias específicas e excepcionais que revelam: a boa fé dos impetrantes; a realização de processo seletivo rigoroso; a observância do regulamento da Infraero, vigente à época da realização do processo seletivo; a existência de controvérsia, à época das contratações, quanto à exigência, nos termos do art. 37 da Constituição, de concurso público no âmbito das empresas públicas e sociedades de economia mista. 8. Circunstâncias que, aliadas ao longo período de tempo transcorrido, afastam a alegada nulidade das contratações dos impetrantes. 9. Mandado de Segurança deferido". MS 22.357-0/DF. Tribunal Pleno. Impetrante: Ivete do Socorro Abreu de Souza e outros. Impetrado: Tribunal de Contas da União. Relator: Ministro Gilmar Mendes. J. 27/05/2004. Brasília, 05 de novembro de 2004. Disponível em: <http://www.stf.jus.br/portal/inteiroTeor/obterInteiroTeor.asp? numero=22357\&classe $=$ MS $>$. Acesso em: 11 nov.2009.

BRASIL. Supremo Tribunal Federal. Ementa: "Mandado de Segurança. 2. Cancelamento de pensão especial pelo Tribunal de Contas da União. Ausência de comprovação da adoção por instrumento jurídico adequado. Pensão concedida há vinte anos. 3. Direito de defesa ampliado com a Constituição de 1988. Âmbito de proteção que contempla todos os processos, judiciais ou administrativos, e não se resume a um simples direito de manifestação no processo. 4. Direito constitucional comparado. Pretensão à tutela jurídica que envolve não só o direito de manifestação e de informação, mas também o direito de ver seus argumentos contemplados pelo órgão julgador. 5. Os princípios do contraditório e 
da ampla defesa, assegurados pela Constituição, aplicam-se a todos os procedimentos administrativos. 6. O exercício pleno do contraditório não se limita à garantia de alegação oportuna e eficaz a respeito de fatos, mas implica a possibilidade de ser ouvido também em matéria jurídica. 7. Aplicação do princípio da segurança jurídica, enquanto subprincípio do Estado de Direito. Possibilidade de revogação de atos administrativos que não se pode estender indefinidamente. Poder anulatório sujeito a prazo razoável. Necessidade de estabilidade das situações criadas administrativamente. 8. Distinção entre atuação administrativa que independe da audiência do interessado e decisão que, unilateralmente, cancela decisão anterior. Incidência da garantia do contraditório, da ampla defesa e do devido processo legal ao processo administrativo. 9. Princípio da confiança como elemento do princípio da segurança jurídica. Presença de um comRelator de ética jurídica. Aplicação nas relações jurídicas de direito público. 10. Mandado de Segurança deferido para determinar observância do princípio do contraditório e da ampla defesa (CF art. $\left.5^{\circ} \mathrm{LV}\right)$ ". MS 24.268-0/MG. Tribunal Pleno. Impetrante: Fernanda Fiuza Brito. Impetrado: Presidente do Tribunal de Contas da União e outro. Relatora: Ministra Ellen Gracie. Relator p/ Acórdão: Ministro Gilmar Mendes. Julgado em 05/02/2004. Brasília, 17 de setembro de 2004. Disponível em: <http://www.stf.jus.br/portal/inteiroTeor lobterInteiroTeor.asp?numero=24268\&classe=MS>. Acesso em: 11 nov.2009.

BRASIL. Supremo Tribunal Federal. "RECURSO EXTRAORDINÁRIO. EFEITOS DA DECLARAÇÃO DE INCONSTITUCIONALIDADE EM TESE PELO SUPREMO TRIBUNAL FEDERAL. ALEGAÇÃO DE DIREITO ADQUIRIDO. Acórdão que prestigiou lei estadual a revelia da declaração de inconstitucionalidade desta ultima pelo Supremo. Subsistência de pagamento de gratificação mesmo após a decisão erga omnes da corte. Jurisprudência do STF no sentido de que a retribuição declarada inconstitucional não e de ser devolvida no período de validade inquestionada da lei de origem - mas tampouco paga após a declaração de inconstitucionalidade. Recurso extraordinário provido em parte". RE 122.202-6/MG. Segunda Turma. Recorrente: Estado de Minas Gerais. Recorrido: Emerson Tardieu de Aguiar Pereira e outros. Relator: Ministro Francisco Rezek. J. 10/08/1993. Brasília, 08 de abril de 1994. Disponível em: http://www.stf.jus.br/portal/inteiroTeor/obterInteiroTeor.asp?numero=122202\&classe=RE. Acesso em: 19 dez. 2009.

BRASIL. Supremo Tribunal Federal. Ementa: "Recurso Extraordinário - Estação Ecológica - Reserva Florestal na Serra Do Mar - Patrimônio Nacional (CF, Art. 225, Par.4.) - Limitação administrativa que afeta o conteúdo econômico do direito de propriedade - Direito do proprietário à indenização - dever estatal de ressarcir os prejuízos de ordem patrimonial sofridos pelo particular - RE não conhecido. - Incumbe ao Poder Público o dever constitucional de proteger a flora e de adotar as necessárias medidas que visem a coibir praticas lesivas ao equilíbrio ambiental. Esse encargo, contudo, não exonera o Estado da obrigação de indenizar os proprietários cujos imóveis venham a ser afetados, em sua potencialidade econômica, pelas limitações impostas pela Administração Pública. A proteção jurídica dispensada às coberturas vegetais que revestem as propriedades imobiliárias não impede que o dominus venha a promover, dentro dos limites autorizados pelo Código Florestal, o adequado e racional aproveitamento econômico das árvores nelas existentes. A jurisprudência do Supremo Tribunal Federal e dos Tribunais em geral, tendo presente a garantia constitucional que protege o direito de propriedade, firmou-se no sentido de proclamar a plena indenizabilidade das matas e revestimentos florestais que recobrem áreas dominiais privadas objeto de apossamento estatal ou sujeitas a restrições administrativas impostas pelo Poder Público. Precedentes. - A circunstância de o Estado 
dispor de competência para criar reservas florestais não lhe confere, só por si considerando-se os princípios que tutelam, em nosso sistema normativo, o direito de propriedade -, a prerrogativa de subtrair-se ao pagamento de indenização compensatória ao particular, quando a atividade pública, decorrente do exercício de atribuições em tema de direito florestal, impedir ou afetar a valida exploração econômica do imóvel por seu proprietário. - A norma inscrita no art. 225, par.4., da Constituição deve ser interpretada de modo harmonioso com o sistema jurídico consagrado pelo ordenamento fundamental, notadamente com a cláusula que, proclamada pelo art. 5., XXII, da Carta Política, garante e assegura o direito de propriedade em todas as suas projeções, inclusive aquela concernente a compensação financeira devida pelo Poder Público ao proprietário atingido por atos imputáveis a atividade estatal. O preceito consubstanciado no art. 225, par.4., da Carta da Republica, além de não haver convertido em bens públicos os imóveis particulares abrangidos pelas florestas e pelas matas nele referidas (Mata Atlântica, Serra do Mar, Floresta Amazônica brasileira), também não impede a utilização, pelos próprios particulares, dos recursos naturais existentes naquelas áreas que estejam sujeitas ao domínio privado, desde que observadas as prescrições legais e respeitadas as condições necessárias a preservação ambiental. - A ordem constitucional dispensa tutela efetiva ao direito de propriedade $(\mathrm{CF} / 88$, art. 5., XXII). Essa proteção outorgada pela Lei Fundamental da Republica estende-se, na abrangência normativa de sua incidência tutelar, ao reconhecimento, em favor do dominus, da garantia de compensação financeira, sempre que o Estado, mediante atividade que lhe seja juridicamente imputável, atingir o direito de propriedade em seu conteúdo econômico, ainda que o imóvel particular afetado pela ação do Poder Público esteja localizado em qualquer das áreas referidas no art. 225, par.4., da Constituição. - Direito ao meio ambiente ecologicamente equilibrado: a consagração constitucional de um típico direito de terceira geração (CF, art. 225, caput). RE 134.297. Primeira Turma. Recorrente: Estado de São Paulo. Recorrido: Paulo Ferreira Ramos e cônjuge. Relator: Ministro Celso de Mello. J. 13/06/1995, Brasília, 22 de setembro de 1995. Disponível em: <http://www.stf.jus.br/portal/inteiroTeor/obterInteiro Teor.asp?numero=134297\&classe=RE $>$. Acesso em: 13 set.2009.

BRASIL. Supremo Tribunal Federal. Ementa: "Recurso extraordinário. 2. Morte de detento por colegas de carceragem. Indenização por danos morais e materiais. 3. Detento sob a custódia do Estado. Responsabilidade objetiva. 4. Teoria do Risco Administrativo. Configuração do nexo de causalidade em função do dever constitucional de guarda (art. $5^{\circ}$, XLX). Responsabilidade de reparar o dano que prevalece ainda que demonstrada a ausência de culpa dos agentes públicos. 5. Recurso extraordinário a que se nega provimento" RE 272.839-0/MT. Segunda Turma. Recorrente: Estado de Mato Grosso. Recorrido: Michele Freitas Leite e outros. Relator: Ministro Gilmar Mendes. J. 01/02/2005. Brasília, 08 de abril de 2005. Disponível em: http://www.stf.jus.br/portal/inteiroTeor/obterInteiroTeor.asp?numero=272839\&classe=RE. Acesso em 18 set. 2009.

BRASIL. Supremo Tribunal Federal. Recurso Extraordinário. Responsabilidade civil do Estado - Declaração de inconstitucionalidade - O Estado responde civilmente pelo dano causado em virtude de ato praticado com fundamento em lei declarada inconstitucional. Recurso Extraordinário no ${ }^{\circ}$. 8.889. João Guerra Luís e outros versus Fazenda do Estado de São Paulo. Relator: Ministro Castro Nunes. J. 19.06.1948. Revista de Direito Administrativo, Rio de Janeiro, v. 20, p. 42-45, 1950. 
BRASIL. Supremo Tribunal Federal. Ementa: "Responsabilidade civil do Estado. Art. 37, $\S 6^{\circ}$ da Constituição Federal. Faute du service public caracterizada. Estupro cometido por presidiário, fugitivo contumaz, não submetido à regressão de regime prisional como manda a lei. Configuração do nexo de causalidade. Recurso Extraordinário desprovido. Impõe-se a responsabilização do Estado quando um condenado submetido a regime prisional aberto pratica, em sete ocasiões, falta grave de evasão, sem que as autoridades responsáveis pela execução da pena lhe apliquem a medida de regressão do regime prisional aplicável à espécie. Tal omissão do Estado constituiu, na espécie, o fator determinante que propiciou ao infrator a oportunidade para praticar o crime de estupro contra menor de 12 anos de idade, justamente no período em que deveria estar recolhido à prisão. Está configurado o nexo de causalidade, uma vez que se a lei de execução penal tivesse sido corretamente aplicada, o condenado dificilmente teria continuado a cumprir a pena nas mesmas condições (regime aberto), e, por conseguinte, não teria tido a oportunidade de evadir-se pela oitava vez e cometer o bárbaro crime de estupro. Recurso extraordinário desprovido". RE 409.203-4/RS. Segunda Turma. Recorrente: Estado do Rio Grande do Sul. Recorrida: Lucia Terezinha Pereira Iorio. Relator: Ministro Carlos Velloso. Relator p/ Acórdão: Ministro Joaquim Barbosa. J. 07/03/2006. Brasília, 20 de abril de 2007. Disponível em: http://www.stf.jus.br/portal/inteiroTeor/obterInteiroTeor.asp?numero=409203\&classe=RE. Acesso em: 18 set.09.

BRASIL. Supremo Tribunal Federal. Ementa: "Responsabilidade civil do Estado. Dano decorrente de assalto por quadrilha de que fazia parte preso foragido vários meses antes. A responsabilidade do Estado, embora objetiva por força do disposto no artigo 107 da Emenda Constitucional n. 1/69 (e, atualmente, no parágrafo 6. do artigo 37 da Carta Magna), não dispensa, obviamente, o requisito, também objetivo, do nexo de causalidade entre a ação ou a omissão atribuída a seus agentes e o dano causado a terceiros. - Em nosso sistema jurídico, como resulta do disposto no artigo 1.060 do Código Civil, a teoria adotada quanto ao nexo de causalidade e a teoria do dano direto e imediato, também denominada teoria da interrupção do nexo causal. Não obstante aquele dispositivo da codificação civil diga respeito a impropriamente denominada responsabilidade contratual, aplica-se ele também a responsabilidade extracontratual, inclusive a objetiva, até por ser aquela que, sem quaisquer considerações de ordem subjetiva, afasta os inconvenientes das outras duas teorias existentes: a da equivalência das condições e a da causalidade adequada. - No caso, em face dos fatos tidos como certos pelo acórdão recorrido, e com base nos quais reconheceu ele o nexo de causalidade indispensável para o reconhecimento da responsabilidade objetiva constitucional, e inequívoco que o nexo de causalidade inexiste, e, portanto, não pode haver a incidência da responsabilidade prevista no artigo 107 da Emenda Constitucional n. 1/69, a que corresponde o parágrafo 6. do artigo 37 da atual Constituição. Com efeito, o dano decorrente do assalto por uma quadrilha de que participava um dos evadidos da prisão não foi o efeito necessário da omissão da autoridade pública que o acórdão recorrido teve como causa da fuga dele, mas resultou de concausas, como a formação da quadrilha, e o assalto ocorrido cerca de vinte e um meses após a evasão. Recurso extraordinário conhecido e provido." RE 130.764. Primeira Turma. Recorrente: Estado do Paraná e Ministério Público do Estado do Paraná. Recorrido: H. Kaminski \& Cia Ltda. e outro. Relator: Ministro Moreira Alves. J. 12.05.1992. Brasília, 12 de maio de 1992. Disponível em: http://www.stf.jus.br/portal/inteiroTeor/obterInteiro Teor.asp?numero=130764\&classe=RE. Acesso em: 08 dez. 2009.

BRASIL. Supremo Tribunal Federal. Ementa: "Responsabilidade civil do Estado: fuga de preso - atribuída à incúria da guarda que o acompanhava ao consultório odontológico fora 
da prisão - preordenada ao assassínio de desafetos a quem atribuía a sua condenação, na busca dos quais, no estabelecimento industrial de que fora empregado, veio a matar o vigia, marido e pai dos autores: indenização deferida sem ofensa do art. 37 , § $6^{\circ}$, da Constituição". RE 136247. Primeira Turma. Recorrente: Estado do Rio de Janeiro. Recorrido: Cremilda Viana de Azeredo e outros. Relator: Ministro Sepúlveda Pertence. J. 20/06/2000. Brasília, 18 de agosto de 2000. Disponível em: $<$ http://www.stf.jus.br/portal/inteiroTeor/obterInteiroTeor.asp?numero=136247\&classe $=\mathrm{R}$ E>>. Acesso em: 08 dez.09.

BRASIL. Supremo Tribunal Federal. "RESPONSABILIDADE CIVIL DO ESTADO LEI INCONSTITUCIONAL - INDENIZAÇÃO. O Estado responde civilmente por danos causados aos particulares pelo desempenho inconstitucional da função de legislar". Recurso Extraordinário $\mathrm{n}^{\circ}$ 153.464. Recorrente: Banco Central do Brasil. Recorrido: Takuro Ogawa e outros. Relator: Ministro Celso de Mello, Julgado em 02. 09.1992. Brasília, 16 de setembro de 1992. Revista de Direito Administrativo, Rio de Janeiro, v. 189, pp. 305-306, 1992.

BRASIL. Supremo Tribunal Federal. Ementa: "I. Responsabilidade civil do Estado: reparação de danos morais e materiais decorrentes de parada cardiorrespiratória durante cirurgia realizada em hospital público. Recurso extraordinário: descabimento. 1. Alegações relativas à nulidade absoluta por defeito de representação processual e à ofensa aos princípios da legalidade e do devido processo legal, que demandariam prévia interpretação de legislação infraconstitucional, inviável no RE: incidência, mutatis mutandis, da Súmula 636. 2. Ausência de prequestionamento do tema dos artigos 100, parágrafos, e 167, II, da Constituição (Súmulas 282 e 356). 3. Controvérsia decidida à luz de fatos e provas, de reexame vedado no RE (Súmula 279). 4. Alegações improcedentes de negativa de prestação jurisdicional e de inexistência de motivação do acórdão recorrido. 5. É da jurisprudência do Supremo Tribunal que, para a configuração da responsabilidade objetiva do Estado não é necessário que o ato praticado seja ilícito. Precedentes. II. Agravo regimental manifestamente infundado: condenação do agravante ao pagamento de multa, nos termos do art. 557, $\S \quad 2^{\circ}, \quad$ C.Pr.Civil”. RE 456.302 AgR. Primeira Turma. Agravante: Estado de Roraima. Agravado: Maria da Guia Santos Lima. Relator: Ministro Sepúlveda Pertence. J. 06/02/2007. Brasília, 16 de março de 2007. Disponível em: http://www.stf.jus.br/portal/inteiroTeor/ obterInteiroTeor.asp?numero=456302\&classe=RE-AgR. Acesso em: 08 dez. 2009.

BRASIL. Supremo Tribunal Federal. Ementa: "Responsabilidade objetiva do Estado. Morte de detento por outro preso. 1. Detento assassinado por outro preso. Responsabilidade objetiva do Estado de reparar o dano. 2. Agravo regimental a que se nega provimento". AgR RE no 466.322. Segunda Turma. Agravante: Estado do Mato Grosso. Agravado: Jeanne Gonçalvez Queiroz. Relator: Ministro Eros Grau. J. 13/03/2007. Brasília, 27 de abril de 2007. Disponível em: http://www.stf.jus.br/portal/inteiroTeor/ obterInteiroTeor.asp?numero=466322\&classe=RE-AgR. Acesso em 18 set. 2009.

BRASIL. Supremo Tribunal Federa. Ementa: "Uma vez praticado pelo poder público um ato prejudicial que se baseou em lei que não é lei, responde ele por suas consequencias". Recurso Extraordinário $\mathrm{n}^{\circ}$ 21.504/PE. Primeira Turma. Recorrente: Pernambuco Autoviária Ltda., Prefeitura Municipal de Recife e outro. Recorrido: os mesmos. Relator: 
Cândido Mota Filho. J. 15.05.57. Revista Trimestral de Jurisprudência, Brasília, v. 2, pp. 121-123, jul./ago. 1957.

ESPANHA. Tribunal Constitucional. Pleno. Decisão: "CUESTIONES DE INCONSTITUCIONALIDAD $\quad 3.563 / 1993, \quad 3.564 / 1993, \quad 3.565 / 1993 \quad$ Y $100 / 1994$ (ACUMULADAS). EN RELACION, LAS TRES PRIMERAS, CON EL ART. 38.2.2 DE LA LEY 5/1990, DE MEDIDAS URGENTES EN MATERIA PRESUPUESTARIA, FINANCIERA Y TRIBUTARIA, QUE CREO UN GRAVAMEN COMPLEMENTARIO DE LA TASA FISCAL SOBRE LOS JUEGOS DE SUERTE, ENVITE O AZAR PARA EL AÑO 1990, Y CON EL APARTADO A), A), DEL NUM. 2 DEL ART. 3.4, DEL REAL DECRETO-LEY 16/1977, POR EL QUE SE REGULAN LOS ASPECTOS PENALES, ADMINISTRATIVOS Y FISCALES DE LOS JUEGOS DE SUERTE, ENVITE O AZAR Y APUESTAS, SEGUN LA NUEVA REDACCION DADA A DICHO PRECEPTO POR EL ART. 38.2.1 DE LA CITADA LEY 5/1990, Y LA CUARTA EN RELACION CON EL ART. 38.2.2 DE LA LEY 5/1990". Sentença 173 de 31 de outubro de 1996. PLENO. SENTENCIA 173/1996, DE 31 DE OCTUBRE DE 1996. Relator: Fernando García-Mon y González-Regueral. BOE 03/12/1996. Disponível em: http://www.boe.es/aeboe/consultas/bases_datos/doc.php?coleccion=iberlex\&id=1996/2718 ․ Acesso em 24.06.09.

ESPANHA. Tribunal Supremo. Sala de lo Contencioso. Decisão: “Que debemos estimar y estimamos el recurso contencioso administrativo interpuesto por el Procurador Don Juan Luis Pérez- Mulet y Suárez, en nombre y representación de la entidad Recreativos Cervera S.L., contra el acuerdo del Consejo de Ministros, de 18 de septiembre de 1998 (expediente I.935/97 y acumulados), en el que se denegó la indemnización reclamada por dicha entidad en concepto de responsabilidad patrimonial derivada de acto del legislador, al ser este acuerdo impugnado contrario a derecho, por lo que lo anulamos, y, con estimación parcial de las pretensiones deducidas por el mencionado Procurador en la indicada representación, debemos condenar y condenamos a la Administración del Estado a que pague a la Empresa Recreativos Cervera S.L. la cantidad de veinticinco millones cuatrocientas ochenta mil novecientas treinta pesetas (153.143 48 euros) más los intereses legales de dicha suma desde el día nueve de diciembre de mil novecientos noventa y dos hasta la fecha de notificación de la presente sentencia, los cuales se calcularán, si fuese preciso, en ejecución de ésta, incrementándose la cantidad total resultante con el interés legal del dinero desde el día de notificación de esta nuestra sentencia hasta su completo pago, sin perjuicio, en caso de incumplimiento, de aumentar dicho interés legal en dos puntos de concurrir las circunstancias previstas para ello, con desestimación de las demás pretensiones formuladas por la entidad demandante, sin hacer expresa condena respecto de las costas procesales causadas. "En nuestro sistema legal, quienes han tenido que satisfacer el gravamen complementario, impuesto por el precepto declarado inconstitucional, después de haber impugnado en via administrativa y sede jurisdiccional dicho gravamen obteniendo sentencia firme que lo declara conforme a derecho, no tienen otra alternativa, en virtud de lo dispuesto por el artículo 40.1 de la Ley Orgánica 2/1979, del Tribunal Constitucional, que ejercitar, como en este caso ha procedido la entidad demandante, una acción por responsabilidad patrimonial, derivada del acto del legislador, dentro del plazo fijado por la ley". Recurso Ordinario n: 562/1998. Relator: Jesus Ernesto Peces Morate. Madrid. Julgado em 21/01/2001. Disponível em http://www.poderjudicial.es/jurisprudencia/pdf/28079130062001100776.pdf?formato=pdf \&K2DocKey=E:ISENTENCIAS 20031030\28079130062001100776.xml@ sent_TS\&quer $\mathrm{y}=\% 28$ gravamen $+\% 3 \mathrm{CAND} \% 3 \mathrm{E}+$ complementario+\%3CAND $\% 3 \mathrm{E}+$ responsabilidad $+\% 3$ 
CAND\%3E+patrimonial+\%3CAND\%3E+legislador\%29\%3CAND\%3E\%28\%3CYESNO $\% 3 \mathrm{E} \% 28 \mathrm{fecha}$ resolucion+\%3E\%3D+20010120\%29\%29. Acesso em 26.06.09.

ESPANHA. Tribunal Supremo. Sala de lo Contencioso. Decisão: “Que debemos estimar y estimamos parcialmente el recurso contencioso-administrativo interpuesto por la representación procesal de D. Gerardo, D. Jesús Ángel, Amarcoy S. L., D. Jaime, D. Juan Carlos, Automáticos Mariano S. L., D. Julián, D. Marco Antonio, Cerjoc S. A., D. Marcos, D. Victor Manuel, Dña. María, D. Narciso, D. Alfredo, D. Ramón, D. Clemente, D. Jose Pedro, Dña. Rocío, D. Francisco, D. Luis Miguel, Dña. Rebeca, Dña. Marina, J.J. Salas S. A., D. Rodolfo, D. Bruno y en su nombre y em representación de su hermano D. Luis Pedro, D. Jesús, Marone S. A., D. Alfonso, D. Sebastián, D. Enrique, D. Luis Angel, D. Javier, D. Casimiro, Dña. Gabriela, Recreativos Holiday S. A., Recreativos Olesa S. A., Recreativos Río S. L., Recreativos Sem S. A., D. Juan Francisco, Reus Player S. A., D. Rosendo, Dña. Lourdes, D. Fernando, D. Juan Miguel, Dña. Margarita en su doble calidad de heredera de su esposo D. Jose Antonio y apoderada para esta reclamación por sus hijos y también herederos Dña. Penélope, D. Mariano, D. Claudio, Dña. Pilar y Dña. Sonia, Servigames S. L., D. Alejandro y D. Juan Antonio contra acuerdo del Consejo de Ministros de 18 de septiembre de 1998 (expediente I.937/97 y acumulados), que declaramos nulo por no ser conforme a derecho. En su lugar, condenamos a la Administración del Estado por el concepto de responsabilidad patrimonial del Estado legislador al abono de las cantidades que se justifique en ejecución de sentencia haber sido ingresadas directamente por los recurrentes o por las empresas respecto de las que se acredite haber comparecido su representante legal en este proceso, como Gravamen Complementario a la Tasa del Juego regulado en el artículo 38.2.2 de la Ley 5/1980, más las cantidades que, a su vez, se justifique haber sido ingresadas por los mismos en calidad de intereses de demora por aplazamiento y, finalmente, los intereses legales de las cantidades ingresadas por uno y otro concepto desde el día de su ingreso. A partir Centro de Documentación Judicial 12 de dicho momento, se devengarán los intereses a que hace referencia el artículo 106 de la Ley reguladora de la Jurisdicción Contencioso-administrativa. No ha lugar a la imposición de las costas causadas. Hágase saber a las partes que contra esta sentencia no cabe recurso ordinario alguno, a excepción del recurso de casación para la unificación de doctrina, que puede interponerse directamente ante la Sala sentenciadora en el plazo de treinta días, contados desde el siguiente a la notificación de la sentencia, contra las sentencias dictadas en única instancia por las Salas de lo Contencioso administrativo del Tribunal Supremo, Audiencia Nacional y Tribunales Superiores de Justicia cuando, respecto a los mismos litigantes u otros diferentes en idéntica situación y, en mérito a hechos, fundamentos y pretensiones sustancialmente iguales, se hubiere llegado a pronunciamientos distintos. Así por esta nuestra sentencia, lo pronunciamos, mandamos y firmamos". Madrid. Recurso Ordinario no: 548/1998. Relator: Juan Antonio Xiol Rios. Madrid. Julgado em: 16 de janeiro de 2001. Disponível em: http://www.poderjudicial.es/jurisprudencia/pdf/ 28079130062001100774.pdf?formato=pdf\&K2DocKey=E:ISENTENCIAS $20031030 \backslash 280$ 79130062001100774.xml@sent_TS\&query=\%28resarcimiento+\%3CAND\%3E+danos\%2 9\%3CAND\%3E\%28\%3CYESNO\%3E\%28fecha_resolucion+\%3E\%3D+20001228\%29\% 29. Acesso em 30.06.09.

ESPANHA. Tribunal Supremo. Sala de lo Contencioso. Decisão: “Que debemos estimar y estimamos parcialmente el recurso contencioso-administrativo interpuesto por la representación procesal de Mercantil Juegomatic, S. A. contra el acuerdo adoptado por el Consejo de Ministros en su reunión del día 12 de diciembre de 1997, en el que se resuelve la reclamación formulada por la recurrente de indemnización por responsabilidad del 
Estado legislador, que anulamos, y, en su lugar, declaramos el derecho de la entidad recurrente a percibir de la Administración del Estado en concepto de responsabilidad patrimonial por acto legislativo la suma de 7230750 pesetas, a la que se añadirá la suma de 1012701 pesetas, abonada en concepto de intereses de demora, incrementada la suma de ambas cantidades con el interés legal que proceda anualmente desde su abono a la Administración hasta la fecha de esta sentencia, a la que será aplicable lo dispuesto sobre intereses de demora por el artículo 106 de la Ley Reguladora de la Jurisdicción contencioso-administrativa. No ha lugar a la imposición de las costas causadas. Hágase saber a las partes que contra esta sentencia no cabe recurso ordinario alguno, a excepción del recurso de casación para la unificación de doctrina, que puede interponerse directamente ante la Sala sentenciadora en el plazo de treinta días, contados desde el siguiente a la notificación de la sentencia, contra las sentencias dictadas en única instancia por las Salas de lo Contencioso administrativo del Tribunal Supremo, Audiencia Nacional y Tribunales Superiores de Justicia cuando, respecto a los mismos litigantes u otros diferentes en idéntica situación $\mathrm{y}$, en mérito a hechos, fundamentos y pretensiones sustancialmente iguales, se hubiere llegado a pronunciamientos distintos". Recurso Ordinario no: 49/1998. Relator: Juan Antonio Xiol Rios. Madrid. Julgado em 29 de fevereiro de 2000. Disponível em: http://www.poderjudicial.es/jurisprudencia/ pdf/28079130062000100510.pdf?formato=pdf\&K2DocKey=E:ISENTENCIAS $\backslash 20031030 \backslash$ 28079130062000100510.xml@sent_TS\&query=\%28responsabilidad+\%3CAND\%3E+esta do+\%3CAND\%3E+ley+\%3CAND\%3E+inconstitucional\%29\%3CAND\%3E\%28\%3CYE SNO\%3E\%28fecha resolucion+\%3E\%3D+20000229\%29\%29. Acesso em 26.06.09.

ESPANHA. Tribunal Supremo. Sala de lo contencioso. Decisão: “Que debemos estimar y estimamos parcialmente el presente recurso contencioso-administrativo promovido por la representación procesal de «Pescanova, S. A.», contra la resolución del Consejo de Ministros de 30 de junio de 1989, por la que fue desestimada la reclamación de daños y perjuicios formulada, entre otras, por la parte actora; cuyo acuerdo, por no ser conforme a Derecho, en el particular cuestionado, anulamos, dejándole sin ningún valor ni efecto y declaramos que el Estado, por el concepto de responsabilidad patrimonial, ha de indemnizar a la Sociedad recurrente en la concreta cantidad que será fijada en ejecución de Sentencia, con arreglo a las siguientes bases: $1 .^{\circ}$ La cantidad principal resultará de la suma total de los derechos aduaneros realmente satisfechos desde 1 de enero de 1987 hasta el 31 de diciembre de 1992, en razón de las importaciones de pescado provenientes de la actividad de las Empresas pesqueras conjuntas en que participa la Sociedad actora, fuera del contingente del derecho nulo, si lo hubiere; $2^{\circ}$ en todo caso se tomará como referencia el cupo exento reconocido a aquellas empresas en $1986 \mathrm{y}$ dentro del cual hubieran tenido cabida las importaciones a cuyos derechos aduaneros nos referimos en el apartado anterior, y $3 .^{\circ}$ la cantidad resultante será actualizada desde la fecha del pago de los derechos aduaneros hasta la efectiva fecha de su abono, aplicando el tipo de interés básico del Banco de España en cada momento vigente y teniendo en consideración la fecha de pago de los respectivos derechos aduaneros y el momento en que los mismos efectivamente se restituyan, y no hacemos pronunciamiento especial sobre las costas causadas. Asi, por esta nuestra sentencia, que se insertará en la COLECCIÓN LEGISLATIVA, definitivamente juzgando, lo pronunciamos, mandamos y firmamos. Recurso contencioso-administrativo. n.. 761 - Sentencia de 5 de marzo de 1993. Relator: Pedro Antonio Mateos García. Madrid. Julgado em 5 de março de 1993. Disponível em: <http://www.poderjudicial.es/search/doAction?action=contentpdf\&databasematch=TS\&ref erence $=1095568 \&$ links $=$ empresa $\% 20 \mathrm{y} \% 20$ pesquera\&optimize $=20051201>$. Acesso em: 16.12.09. 
ESPANHA. Tribunal Supremo. Sala de lo Contencioso. Decisão: "Que debemos estimar y estimamos el recurso contencioso administrativo interpuesto por PESQUERIAS ESPAÑOLAS DE BACALAO S.A. (PEBSA) contra acto presunto de 28 de Febrero de 1987 y acuerdo de Consejo de Ministros de 30 de Junio de 1989 que anulamos por ser contrarios a Derecho y debemos declarar y declaramos el derecho de la recurrente a ser indemnizada por los perjuicios sufridos como consecuencia de la aplicación del artículo 168 del Acta de Adhesión de España a la Comunidad Europea de 12 de Junio de 1985 en la cantidad que se fije en ejecución de sentencia con arreglo a los criterios establecidos en el Fundamento Jurídico Sexto. Sin costas. Así por esta nuestra sentencia, firme , lo pronunciamos, mandamos y firmamos". Recurso Ordinario $n^{\circ}$ 265/1988. Relator: Jose Manuel Sieira Miguez. Madrid. Julgado em 16 de setembro de 1997. Disponível em: http://www.poderjudicial.es/search/doAction?action=contentpdf\&databasematch=TS\&refe rence $=3155451 \&$ links $=$ responsabilidad $\% 20 \mathrm{y} \% 20$ estado\&optimize $=20030912$. Acesso em: 16.12.09.

ESPANHA. Tribunal Supremo. Sala de lo Contencioso. Decisão: "Que debemos estimar y estimamos parcialmente el recurso contencioso-administrativo interpuesto por la representación procesal de VIHERMATIC, SOCIEDAD CIVIL contra acuerdo del Consejo de Ministros de 18 de Septiembre de 1998, que declaramos nulo por no ser conforme a derecho. En su lugar, condenamos a la Administración del Estado por el concepto de responsabilidad patrimonial del Estado legislador al abono de la siguiente cantidad: 7.233.850 pesetas a favor de VIHERMATIC, SOCIEDAD CIVIL. A dicha cantidad se añadirá el interés legal del dinero desde el momento en que fue ingresada hasta la notificación de esta sentencia. A partir de dicho momento, se devengarán los intereses a que hace referencia el artículo 106 de la Ley reguladora de la Jurisdicción Contenciosoadministrativa. No ha lugar a la imposición de las costas causadas. Hágase saber a las partes que contra esta sentencia no cabe recurso ordinario alguno, a excepción del recurso de casación para la unificación de doctrina, que puede interponerse directamente ante la Sala sentenciadora en el plazo de treinta días, contados desde el siguiente a la notificación de la sentencia, contra las sentencias dictadas en única instancia por las Salas de lo Contencioso administrativo del Tribunal Supremo, Audiencia Nacional y Tribunales Superiores de Justicia cuando, respecto a los mismos litigantes u otros diferentes en idéntica situación y, en mérito a hechos, fundamentos y pretensiones sustancialmente iguales, se hubiere llegado a pronunciamientos distintos. Así por esta nuestra sentencia, firme, lo pronunciamos, mandamos y firmamos". Recurso Ordinario $n^{\circ}$ : 532/1998. Relator: Jose Manuel Sieira Miguez. Madrid. Julgado em 08 de março de 2001. Disponível em: http://www.poderjudicial.es/jurisprudencia/pdf/28079130062001100383.pdf?formato=pdf \&K2DocKey=E:ISENTENCIAS 20031018\28079130062001100383.xml@ sent_TS\&quer $\mathrm{y}=\% 28 \mathrm{responsabilidad}+\% 3 \mathrm{CAND} \% 3 \mathrm{E}+\mathrm{estado}+\% 3 \mathrm{CAND} \% 3 \mathrm{E}+\mathrm{ley}+\% 3 \mathrm{CAND} \% 3 \mathrm{E}+\mathrm{inco}$ nstitucional \%29\%3CAND\%3E\%28\%3CYESNO $\% 3 \mathrm{E} \% 28 \mathrm{fech}$ _ resolucion+\%3E\%3D+20 000229\%29\%29. Acesso em 26.06.09. 